MAYSA DAMANTE TRAVAIN

POTENCIAL DE SUBSTITUIÇÃO DE CIMENTO POR FINOS DE QUARTZO EM MATERIAIS CIMENTÍCIOS 



\title{
POTENCIAL DE SUBSTITUIÇÃO DE CIMENTO POR FINOS DE QUARTZO EM MATERIAIS CIMENTÍCIOS
}

\author{
Versão Corrigida \\ (A versão original encontra-se na unidade que aloja \\ o programa de pós-graduação)
}

Dissertação de mestrado apresentada ao Instituto de Arquitetura e Urbanismo da Universidade de São Paulo para obtenção do título de mestre em Arquitetura e Urbanismo.

Área de concentração:

Arquitetura, Urbanismo e Tecnologia.

Orientador:

Bruno Luis Damineli

São Carlos

2019 


\section{AUTORIZO A REPRODUCAO TOTAL OU PARCIAL DESTE TRABALHO, POR QUALQUER MEIO CONVENCIONAL OU ELETRONICO, PARA FINS DE ESTUDO E PESQUISA, DESDE QUE CITADA A FONTE}

Ficha catalográfica elaborada pela Biblioteca do Instituto de Arquitetura e Urbanismo com os dados fornecidos pelo(a) autor(a)

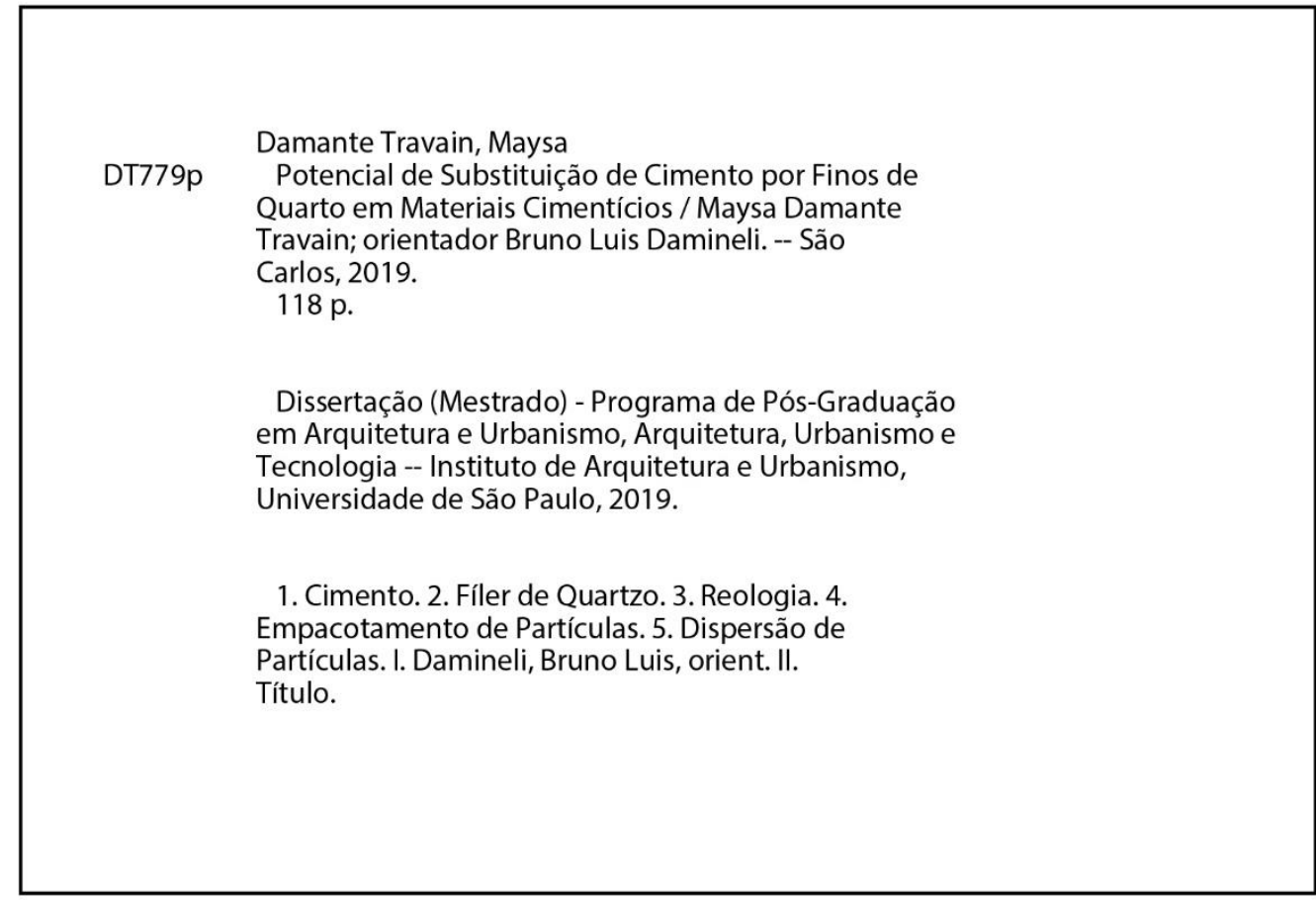

Bibliotecária responsável pela estrutura de catalogação da publicação de acordo com a AACR2: Brianda de Oliveira Ordonho Sígolo - CRB - 8/8229 


\section{FOLHA DE JULGAMENTO}

\section{Candidato(a): Maysa Damante Travain}

Título da dissertação: "Potencial de substituição de cimento por finos de quartzo em materiais cimentícios"

Data da defesa: 20/03/2019

Orientador: Prof. Dr. Bruno Luis Damineli

Comissão Julgadora:

Resultado:

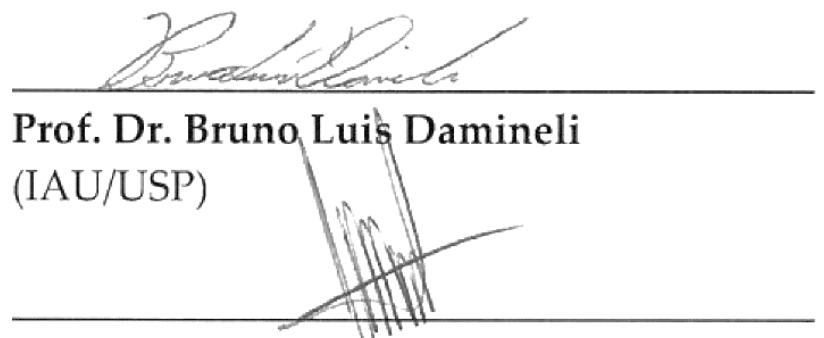

Não votante

Prof. Dr. Javier Mazariegos Pablos

(IAU/USP)

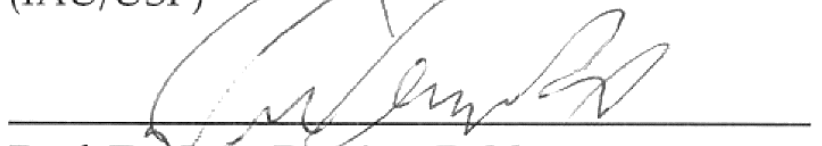

Prof. Dr. Joấo Baptista Baldo

(UFSCar)
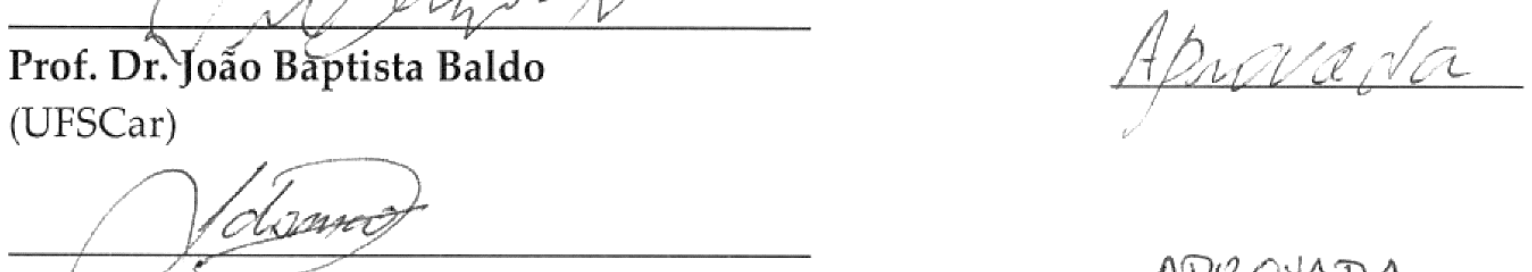

Prof. Dr. Rafael Salomão

(EESC/USP)

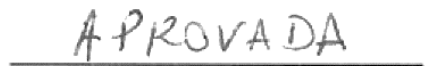

APROVADA

Coordenador e Presidente da Comissão de Pós-Graduação do Programa de PósGraduação em Arquitetura e Urbanismo: Prof. Dr. Tomás Antonio Moreira. 

Dedico este trabalho aos meus pais, Maria Luiza e Luiz Otavio, que sempre me deram suporte e me incentivaram para que eu atingisse os meus objetivos. 


\section{AGRADECIMENTOS}

Ao Instituto de Arquitetura e Urbanismo da USP, pela oportunidade de realizar e concluir o curso de mestrado.

Ao apoio financeiro, concedido para a conclusão da minha pesquisa, pela Coordenação de Aperfeiçoamento de Pessoal de Nível Superior - Brasil (CAPES) - Código de Financiamento 001.

À mineradora Jundu, pela doação das matérias-primas utilizadas nos experimentos da pesquisa. Aos servidores técnicos do Laboratório de Construção Civil do Instituto de Arquitetura e Urbanismo, pela atenção e auxílio prestados durante a execução dos experimentos desta pesquisa.

Ao departamento de Engenharia de Materiais da Escola de Engenharia de São Carlos, por disponibilizar o laboratório para realização de alguns ensaios necessários.

Ao meu orientador Prof. Bruno Luis Damineli, pelos ensinamentos que contribuíram para o meu desenvolvimento pessoal, científico e intelectual, sem os quais o andamento e a conclusão desta pesquisa não seria possível.

Aos professores membros da minha banca de qualificação, Prof. Javier Mazariegos Pablos e Prof. Rafael Salomão, pelas orientações e discussões que contribuíram de modo significativo para a melhoria do meu trabalho.

Aos meus pais, por investirem na minha formação e acreditarem no meu potencial, em especial ao meu pai, que faleceu sem poder ver a conclusão de mais esta etapa da minha vida.

Aos meus amigos por me darem suporte emocional e paciência, durante os meus momentos de crises. 


\section{RESUMO}

TRAVAIN, M. D. Potencial de substituição de cimento por finos de quartzo em materiais cimentícios. 2019. 118 p. Dissertação (Mestrado em Arquitetura e Urbanismo) Instituto de Arquitetura e Urbanismo, Universidade de São Paulo, São Carlos, 2019.

O uso do cimento nas dosagens de materiais cimentícios sempre foi uma preocupação na construção civil por questões de custo. Com o surgimento das discussões sobre sustentabilidade, as preocupações passam a ocorrer também com relação aos impactos ambientais gerados em sua produção, principalmente as emissões de $\mathrm{CO}_{2}$. Apesar de grandes esforços industriais para a redução destas emissões, as estratégias adotadas não têm sido eficientes para atingir patamares de redução suficientes. Neste cenário, a substituição de parte do cimento por finos inertes, conhecidos como fíleres, provenientes de matérias-primas abundantes e baratas, podem proporcionar ganhos econômicos e ambientais, já que estes materiais apresentam menor impacto de produção por não necessitarem serem submetidos a processos térmicos. Além disso, a adição de fíleres na matriz cimentícia pode contribuir para o aumento da eficiência dos ligantes, pois possibilita o melhor empacotamento de partículas, com diminuição de vazios, que contribui para a redução do teor de água na mistura - o que significa possibilidade de desempenho mecânico satisfatório com menos clínquer. O presente trabalho teve como objetivo avaliar o potencial de substituição de parte do cimento por fíleres de quartzo em pastas cimentícias, visando reduzir o consumo de clínquer. Foram avaliados os comportamentos reológicos e mecânicos de dosagens de pastas e argamassas de clínquer-fíler, verificando o desempenho dos materiais produzidos. Para estudo das pastas foram feitas caracterizações das matérias-primas, ensaios de reologia para determinar o teor ótimo de dispersante, e ensaios de resistência à compressão para teores de água fixos, variando os fíleres com três composições granulométricas distintas. Para avaliação das argamassas, foram realizados ensaios de resistência à compressão e determinados os módulos de elasticidade. A análise dos resultados foi feita por meio de comparativos entre os comportamentos reológicos e mecânicos das misturas, além do cálculo do indicador de eficiência Binder Intensity (BI), que é uma relação entre o consumo de cimento e a resistência mecânica. Os materiais produzidos com fíleres atingiram comportamentos reológicos próximos ao material convencional, mas com teores de água reduzidos, contribuindo para o alcance de boas resistências mecânicas com menor consumo de cimento, e módulos de elasticidade equivalentes. Os resultados obtidos nos 
experimentos realizados comprovam os ganhos de eficiência alcançados com a adição de fíleres de quartzo em materiais cimentícios e a viabilidade para aplicação na construção civil.

Palavras-chave: Cimento. Fíler de Quartzo. Reologia. Empacotamento de Partículas. Dispersão de Partículas. Sustentabilidade. 


\begin{abstract}
TRAVAIN, M. D. Potential of cement replacement by quartz powder in cementitious materials. 2019. 118 p. Dissertação (Mestrado em Arquitetura e Urbanismo) Instituto de Arquitetura e Urbanismo, Universidade de São Paulo, São Carlos, 2019.
\end{abstract}

The use of cement in cementitious material's dosages has always been a concern in civil construction for costs issues. With the emergence of sustainability discussions, also arise concerns about environmental impacts generated in its production, mainly $\mathrm{CO}_{2}$ emissions. Although the large industrials efforts to reduce these emissions, the strategies adopted haven't been efficient to achieve sufficient reduction levels. In this scenario, partial replacement of cement by inert fines, denominated fillers, from abundant and cheap raw materials, can provide environmental and economic gains, since these materials produce lower environmental impact as they don't need to be submitted to thermal processes. Beyond that, the filler's addition in cementitious matrix can contribute to the increase of binders' efficiency, as it allows the particles' packaging, with the decreasing of voids, which contributes to the reduction of water content in the mixture - which means possibility of satisfactory mechanical performance with less clinker content. Thus, this study aims to evaluate the potential of cement replacement by quartz fíller in cement mixtures, in order to reduce clinker's consumption. Were evaluated the rheological and mechanical behavior of pastes and mortars dosages made of clinker-filler, and was verified the performance of the materials produced. To the paste study, were made raw materials' characterizations, rheology tests to determine the optimum dispersant content, and compressive strength tests for fixed water contents, varying three fillers with different particle sizes. For mortars evaluation, were performed compressive strength tests and was determined the elastic modulus. The analysis of the results were made though comparisons between mixtures' rheological and mechanical behaviors, besides the calculation of the efficiency index Binder Intensity (BI), which is a relation between cement consumption and the mechanical strength. The materials produced with fillers reached a rhealogical behavior close to the conventional material's behavior, but with reduced water contents, contributing to the achievement of good mechanical resistance with lower cement consumption, and equivalentmodulus of elasticity. The results obtained in the experiments performed demonstrate the efficiency gains achieved with the addition of quartz' fillers in cementitious materials and the feasibility for application in the civil construction industry. 
Keywords: Cement. Quartz Filler. Rheology. Particle Packing. Particle Dispersion. Sustainability. 


\section{LISTA DE FIGURAS}

Figura 1 - Anomalias nas temperaturas continentais, observadas de 1906 até 2005 e projeções até 2050. 6

Figura 2 - Emissões de CO2 globais de 1960 a 2017 ........................................................ 7

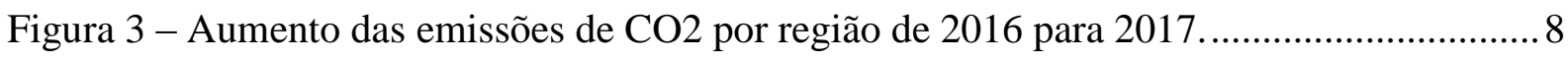

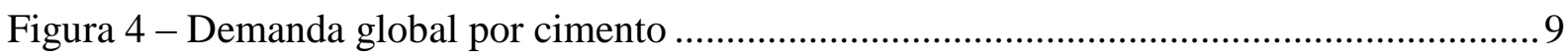

Figura 5 - Quilograma de $\mathrm{CO} 2$ emitidos por tonelada de cimento produzido.......................... 10

Figura 6 - Resumo esquemático da produção das cinzas volantes na queima do carvão......... 13

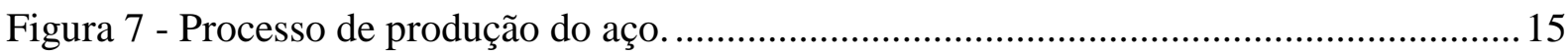

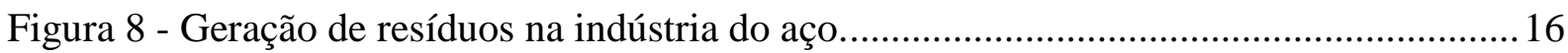

Figura 9 - Mecanismos de estabilização de suspensões........................................................2 28

Figura 10 - Modelo de lâminas paralelas de Newton: duas lâminas movendo-se com

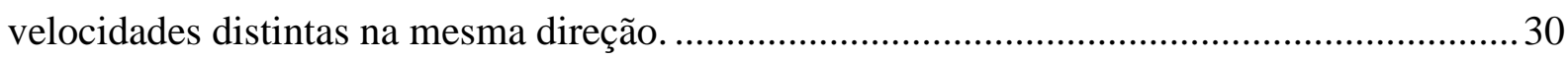

Figura 11 - Comportamentos reológicos independentes do tempo...................................... 32

Figura 12 - Comportamentos reológicos dependentes do tempo ......................................... 35

Figura 13 - Esquema de execução do ensaio de Funil de Marsh ............................................ 37

Figura 14 - Funil de Marsh usado para medida indireta da viscosidade................................ 37

Figura 15 - Curva típica dos resultados dos ensaios de Funil de Marsh ................................38

Figura 16 - Funil de Marsh acoplado na canaleta de vidro ................................................. 38

Figura 17 - Espalhamento das suspensões de acordo com o teor de dispersante ....................39

Figura 18 - Esquema de execução do ensaio de espalhamento pelo minicone......................... 40

Figura 19 - Minicone utilizado para medida indireta da tensão de escoamento..................... 40

Figura 20 - Curva típica dos resultados dos ensaios de espalhamento pelo minicone ............ 41

Figura 21 - variação do diâmetro de espalhamento com o tempo .......................................... 41

Figura 22 - Planejamento experimental da etapa 1 esquematizado .................................... 45

Figura 23 - Planejamento experimental da etapa 2 esquematizado ........................................45 
Figura 24 - Planejamento experimental da etapa 3 esquematizado 45

Figura 25 - Argamassadeira utilizada para homogeneização das matérias-primas..... 47

Figura 26 - Misturador utilizado para altas velocidades de cisalhamento e dispersão 48

Figura 27 - Equipamento utilizado para ensaio de consistência 50

Figura 28 - Etapas de execução do ensaio de consistência das argamassas 51

Figura 29 - Ensaio para avaliação da viscosidade, utilizando o Funil de Marsh 53

Figura 30 - Aspecto das pastas durante o ensaio de espalhamento pelo Minicone. 54

Figura 31 - Formas de PVC acopladas no suporte de aço 55

Figura 32 - Corpos de prova fixados na forma de madeira 56

Figura 33 - Forma com os corpos de prova no roller mecânico 56

Figura 34 - homogeneização dos corpos de prova após rotação 57

Figura 35 - Corpos de prova de argamassas 57

Figura 36 - Prensa utilizada para compressão dos corpos de prova 58

Figura 37 - Mecanismo de funcionamento da Técnica de Excitação por Impulso 59

Figura 38 - Equipamento Sonelastic ATCP Engenharia Física 59

Figura 39 - Composição Granulométrica dos fíleres, curva discreta 61

Figura 40 - Composição granulométrica dos fíleres, porcentagem acumulada 62

Figura 41 - Composição granulométrica da areia (AJ6), curva discreta. 62

Figura 42 - Composição granulométrica da areia (AJ6), porcentagem acumulada 62

Figura 43 - Teor de aditivo x Tempo de Marsh para as pastas de cimento. 65

Figura 44 - Teor de aditivo x Espalhamento para as pastas de cimento 66

Figura 45 - Tempo de Marsh x Teor de aditivo para as pastas de fíleres no fator a/s 0,30 ..... 67

Figura 46 - Teor de aditivo x Espalhamento para pastas de quartzo com a/s 0,30 68

Figura 47- Tempo de Marsh x Teor de aditivo para as pastas de fíleres no fator a/s 0,30 ...... 69

Figura 48 - Teor de aditivo x Espalhamento para pastas de fíler de quartzo com a/s 0,33 .... 70

Figura 49 - Inicio de segregação observada no ensaio de espalhamento ..... 71 
Figura 50 - Teor de aditivo x Tempo de Marsh para as pastas 40\% quartzo, na granulometria SM200 .72

Figura 51 - Teor de aditivo x Espalhamento para as pastas $40 \%$ quartzo, na granulometria SM200 73

Figura 52- Teor de aditivo x Tempo de Marsh para as pastas 60\% quartzo na granulometria SM200 74

Figura 53 - Teor de aditivo x Espalhamento para as pastas $60 \%$ quartzo na granulometria SM200 .74

Figura 54 - Teor de aditivo x Tempo de Marsh para as pastas $40 \%$ quartzo na granulometria SM325 75

Figura 55 - Teor de aditivo x Espalhamento para as pastas $40 \%$ quartzo na granulometria SM325 76

Figura 56 - Teor de aditivo x Tempo de Marsh para as pastas $60 \%$ quartzo na granulometria SM325 77

Figura 57 - Teor de aditivo x Espalhamento para as pastas 60\% quartzo na granulometria SM325 77

Figura 58 - Teor de aditivo x Tempo de Marsh para as pastas $40 \%$ quartzo na granulometria SM400 78

Figura 59 - Teor de aditivo x Espalhamento para as pastas $40 \%$ quartzo na granulometria SM400 .79

Figura 60 - Teor de aditivo x Tempo de Marsh para as pastas $60 \%$ quartzo na granulometria SM400 80

Figura 61 - Teor de aditivo x Espalhamento para as pastas 60\% quartzo na granulometria SM400

Figura 62 - Comparativos entre Teor de aditivo x Espalhamento das pastas no fator a/s 0,21

Figura 63 - Comparativos entre Teor de aditivo x Tempo de Marsh das pastas no fator a/s 0,21

Figura 64 - Comparativos entre Teor de aditivo x Espalhamento das pastas no fator a/s 0,23 
Figura 65 - Comparativos entre Teor de aditivo x Tempo de Marsh das pastas no fator a/s 0,23

Figura 66 - Comparativos do Teor de aditivo x Espalhamento das pastas no fator a/s 0,25... 85

Figura 67 - Comparativos entre Teor de aditivo x Tempo de Marsh das pastas no fator a/s 0,25

Figura 68 - Reprodutibilidade do espalhamento das pastas de CPV, fator a/s $0,21 \ldots \ldots \ldots \ldots \ldots . . . .87$

Figura 69 - Reprodutibilidade do Funil de Marsh das pastas de CPV, fator a/s 0,21 ........... 87

Figura 70 - Reprodutibilidade do espalhamento das pastas de CPV, fator a/s $0,25 \ldots \ldots \ldots \ldots \ldots . . .88$

Figura 71 - Reprodutibilidade do Funil de Marsh das pastas de CPV, fator a/s 0,25 ........... 88

Figura 72 - Reprodutibilidade do espalhamento das pastas de SM200, fator a/s 0,21 .......... 89

Figura 73 - Reprodutibilidade do Funil de Marsh das pastas de SM200, fator a/s 0,21 ........ 89

Figura 74 - Reprodutibilidade do espalhamento das pastas de SM200, fator a/s 0,25......... 90

Figura 75 - Reprodutibilidade do Funil de Marsh das pastas de SM200, fator a/s 0,25 ........ 90

Figura 76 - Reprodutibilidade do espalhamento das pastas de SM400, fator a/s 0,21 .......... 91

Figura 77 - Reprodutibilidade do Funil de Marsh das pastas de SM400, fator a/s 0,21 ........ 91

Figura 78 - Reprodutibilidade do espalhamento das pastas de SM400, fator a/s 0,25 .......... 92

Figura 79 - Reprodutibilidade do Funil de Marsh das pastas de SM400, fator a/s 0,25 ........ 92

Figura 80 - Trabalhabilidade das pastas no Funil de Marsh, fator a/s 0,21 ......................... 93

Figura 81 - Trabalhabilidade das pastas no espalhamento pelo minicone, fator a/s $0,21 \ldots \ldots . .93$

Figura 82 - Trabalhabilidade das pastas com fíleres SM400 no Funil de Marsh, fator a/s 0,25

Figura 83 - Trabalhabilidade das pastas com fíleres no espalhamento pelo minicone, fator a/s

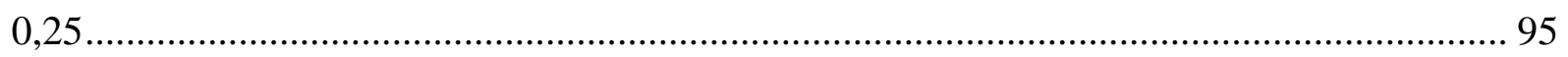

Figura 84 - Resistência média das pastas com fator a/s 0,21 aos 7 dias ............................. 96

Figura 85 - Resistência média das pastas com fator a/s 0,21 aos 28 dias ............................. 96

Figura 86 - Resistência média das pastas com fator a/s 0,25 aos 7 dias .............................. 97

Figura 87 - Resistência média das pastas com fator a/s 0,25 aos 28 dias .............................. 97 
Figura 88 - Resistência média das argamassas aos 7 dias 99

Figura 89 - Resistência média das argamassas aos 28 dias 99

Figura 90 - Resistência à compressão média aos 28 dias x fator a/s 100

Figura 91 - Módulo de elasticidade médio das argamassas x Consumo de cimento 101

Figura 92 - Índice de eficiência das pastas com fator a/s 0,21 102

Figura 93 - Índice de eficiência das pastas com fator a/s 0,25 103

Figura 94 - Índice de Eficiência das argamassas x Consumo de cimento 104 


\section{LISTA DE TABELAS}

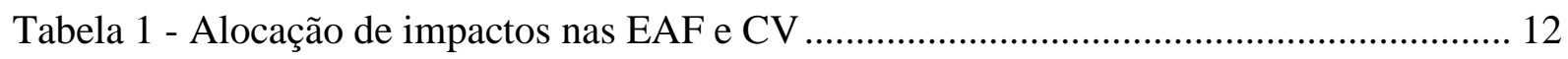

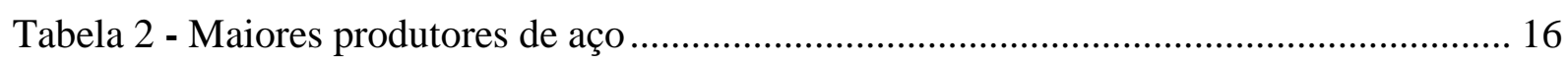

Tabela 3 - Composição das pastas de cimento com fator água/cimento ................................ 48

Tabela 4 - Composição das pastas de fíleres com fator água/sólidos ................................... 49

Tabela 5 - Composição em volume das pastas de cimento-fíler ........................................ 49

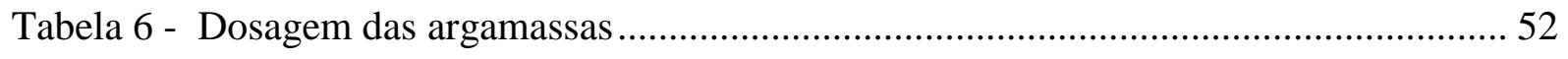

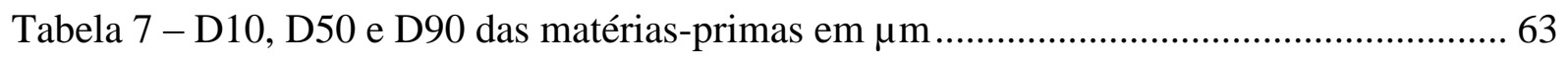

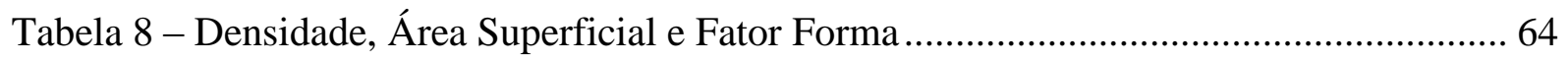

Tabela 9 - Desvio padrão dos resultados de resistência à compressão das pastas aos 7 e 28 dias

Tabela 10 - Desvio padrão dos resultados de resistência à compressão das pastas aos 7 e 28

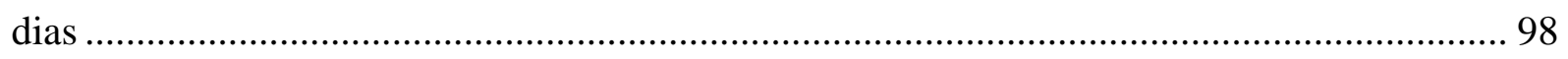

Tabela 11 - Desvio padrão dos resultados de resistência à compressão das argamassas aos 7 e 28 dias 100

Tabela 12 - Desvio padrão dos módulos de elasticidade das argamassas. 101 


\section{SUMÁRIO}

1 INTRODUÇÃO .................................................................................................1

2 IMPACTOS AMBIENTAIS DO CIMENTO E ESTRATÉGIAS PARA SUA

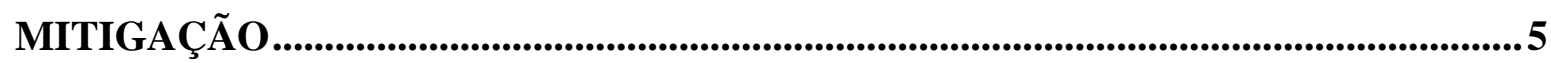

Aquecimento global e projeções futuras ..............................................

2.2 Impactos ambientais da cadeia de produção do cimento ............................ 8

2.3 Mitigação das emissões de poluentes na produção de cimento ................... 10

2.3.1 Eficiência energética na produção ....................................................... 10

2.3.2 Substituição do clínquer por adições minerais .................................... 11

2.3.3 Substituição dos combustíveis tradicionais ..................................... 17

2.3.4 Captura e sequestro de carbono ....................................................... 17

2.4 Pasta com menor teor de ligantes - o uso dos fíleres ................................. 18

2.4.1 Uso de fíler calcário....................................................................... 19

2.4.2 Uso de fíler de quartzo............................................................. 19

2.4.2.1 Desafios toxicológicos........................................................ 21

2.4.2.2 Desafios científicos e tecnológicos...............................................22

3 COMPORTAMENTO REOLÓGICO DAS SUSPENSÕES.......................... 25

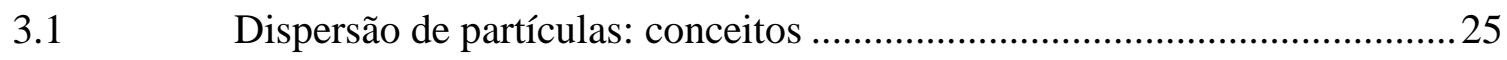

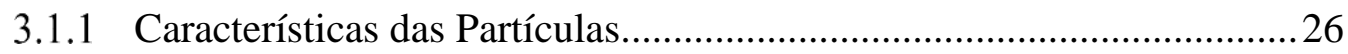

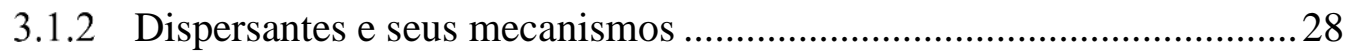

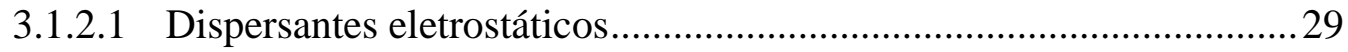

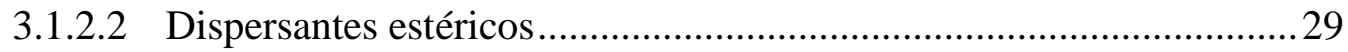

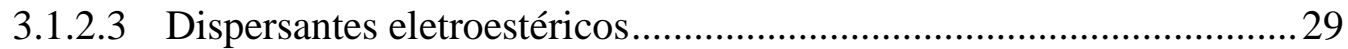

3.1.3 Viscosidade e Tensão de Escoamento .................................................. 30

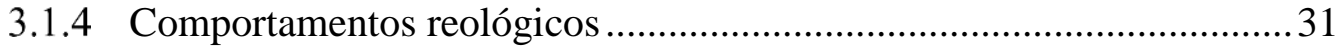


3.1.4.1 Comportamento Pseudoplástico...................................................... 32

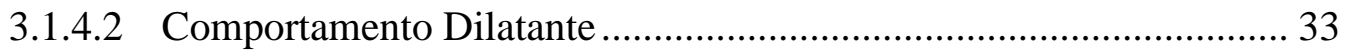

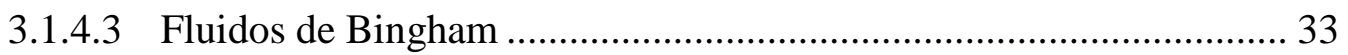

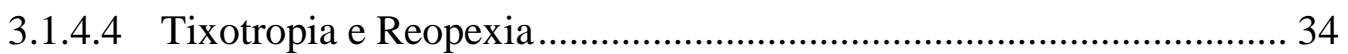

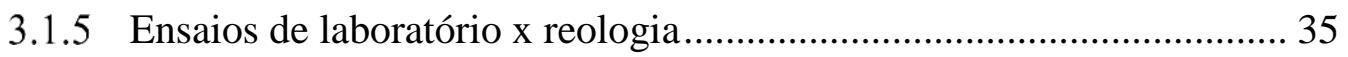

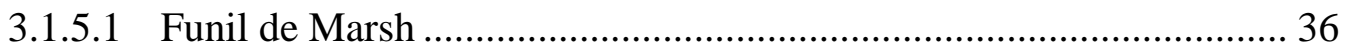

3.1.5.2 Minicone: espalhamento e tempo de espalhamento.......................... 39

4 FORMULAÇÃO dE PASTAS E ARGAMASSAS EFICIENTES ............. 43

4.1 Planejamento experimental, materiais e métodos................................... 43

4.1.1 Caracterização de matérias-primas ................................................. 46

4.1.1.1 Composição granulométrica ....................................................... 46

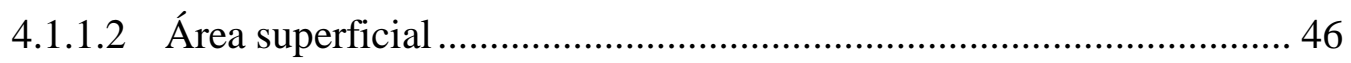

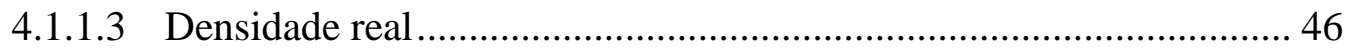

4.1.2 Procedimentos de mistura das pastas ................................................ 47

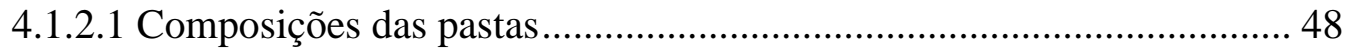

4.1.3 Procedimentos de mistura das argamassas....................................... 50

4.1.3.1 Composições das argamassas........................................................... 51

4.1.4 Comportamento Reológico das Pastas ............................................. 52

4.1.4.1 Descrição: ensaio de Funil de Marsh ................................................... 53

4.1.4.2 Descrição: ensaio de espalhamento pelo minicone ........................... 53

4.1.4.3 Determinação do teor ótimo de dispersante .................................... 54

4.1.4.4 Procedimentos de moldagem dos corpos de prova das pastas........... 55

4.1.4.5 Procedimentos de moldagem dos corpos de prova das argamassas... 57

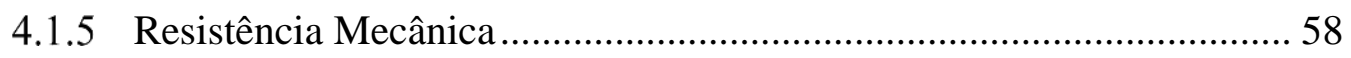

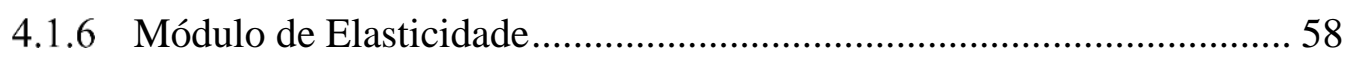

4.1.7 Cálculo do Índice de Eficiência (BI) ............................................. 59 
5 RESULTADOS E DISCUSSÕES

5.1 Caracterização das matérias-primas 61

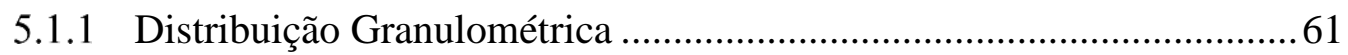

5.1.2 Área Superficial e Fator Forma .........................................................6 63

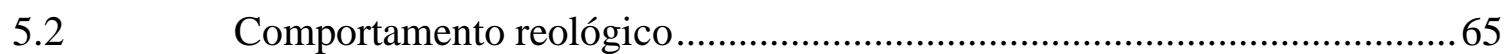

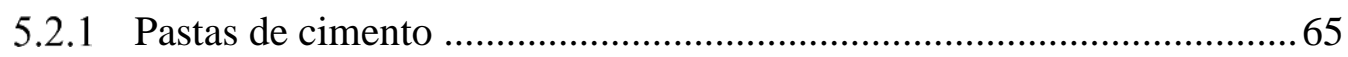

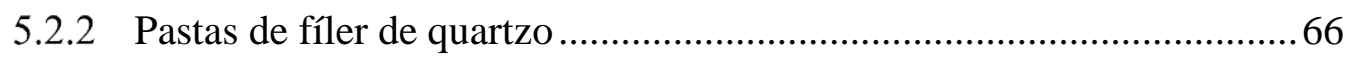

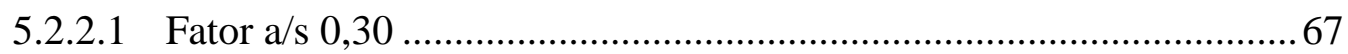

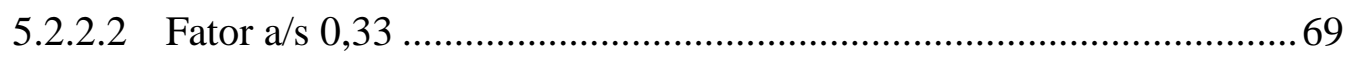

5.2.3 Pastas de clínquer-fíler .............................................................. 71

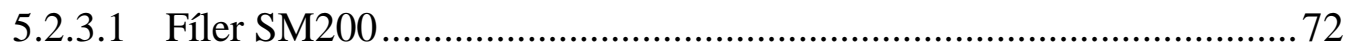

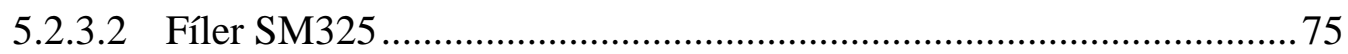

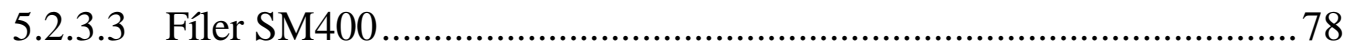

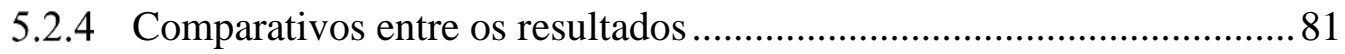

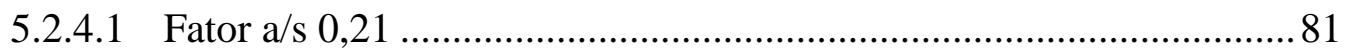

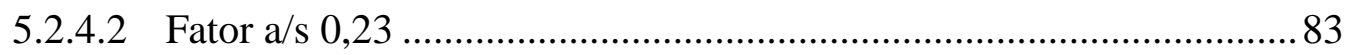

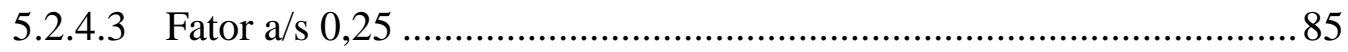

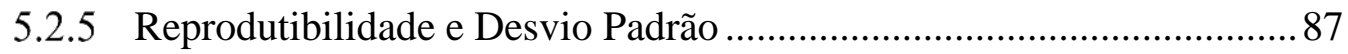

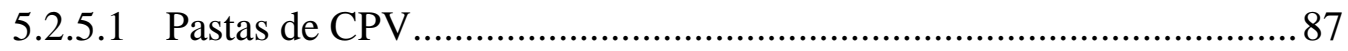

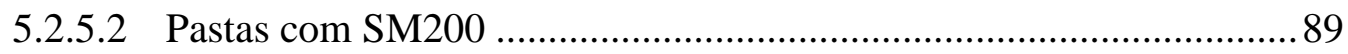

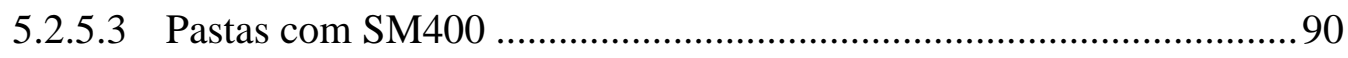

5.2.6 Trabalhabilidade das pastas .......................................................... 93

Resistência à compressão dos corpos de prova de pastas .......................... 95

Resistência à compressão dos corpos de prova de argamassas .................... 98

5.5 Módulo de elasticidade das argamassas ............................................... 100

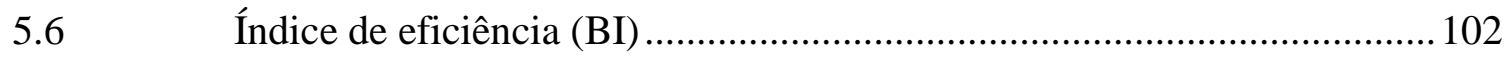


5.6.1 Índice de Eficiência das Pastas ........................................................ 102

5.6.2 Índice de Eficiência das Argamassas ................................................ 103

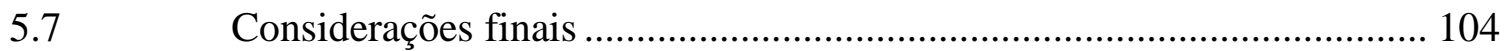

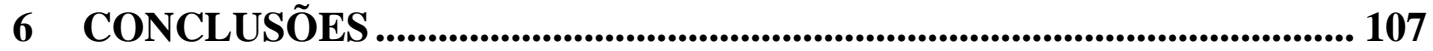

7 REFERÊNCIAS BIBLIOGRÁFICAS ............................................................. 111 



\section{INTRODUÇÃO}

O aquecimento global é motivo de preocupação mundial, devido às previsões de que a temperatura média da Terra atinja níveis críticos até 2100. De acordo com Jackson et al. (2017), as taxas de emissões de gases de efeito estufa, principalmente do $\mathrm{CO}_{2}$, se mantiveram estáveis entre 2014 e 2016. Essa estabilização ocorreu devido às estratégias adotadas pelos países como a diminuição do uso de combustíveis fósseis, investimentos em eficiência energética e implantação de fontes de energias renováveis, porém as temperaturas médias de diversas regiões do globo continuaram a subir.

Diante desse cenário, o Acordo de Paris, estabelecido pela comunidade internacional, propôs metas para redução das emissões de poluentes, de modo que o aumento da temperatura média do planeta seja inferior à $1,5^{\circ} \mathrm{C}$ até o final do século. Entretanto, estudos recentes feitos por Jackson et al. (2017), baseados no crescimento do produto interno bruto global, alertam para um aumento de cerca de $2 \%$ nas emissões de $\mathrm{CO}_{2}$ em 2017 comparado a 2016, com tendência a maiores índices em 2018. As estimativas feitas pelos pesquisadores, demonstram que as iniciativas adotadas até o momento pelos países são insuficientes para estabilizar os impactos previstos.

Essas previsões são decorrentes da intensificação do uso de combustíveis fósseis como o carvão mineral e o petróleo na produção de energia primária, principalmente pela China e Índia, que apresentam tendência de expansão econômica e populacional (INTERNATIONAL ENERGY AGENCY, 2018; JACKSON et al., 2017; WORLD CEMENT ASSOCIATION, 2018). Segundo o relatório publicado pela Organização das Nações Unidas (ONU) em 2017, a população mundial aumentou de 7,4 bilhões em 2015 para 7,6 bilhões em 2017, podendo atingir 8,6 bilhões em 2030 com maior concentração de pessoas nos países mais pobres e em desenvolvimento. Logo, surge o impasse entre sustentar o desenvolvimento econômico necessário, trazido pelo aumento populacional, ou reduzir as emissões de $\mathrm{CO}_{2}$, exigindo maiores esforços para conter o aquecimento global.

$\mathrm{O}$ crescimento populacional exige maiores demandas por infraestrutura habitacional e urbana, sendo a construção civil uma das maiores causadoras de impactos ambientais, principalmente através do uso de cimento para a moldagem de concretos e outros materiais cimentícios. De acordo com Le Quéré et al. (2018), a fabricação do cimento é responsável por $8 \%$ das emissões mundiais de $\mathrm{CO}_{2}$, devido à queima de combustíveis, à extração de matérias- 
primas e ao processo de decomposição do calcário na produção do clínquer. Diante das pressões ambientais, as indústrias cimenteiras implementaram a substituição do clínquer por resíduos reativos de outros processos industriais, como a escória granulada de alto forno (EAF), subproduto da redução do minério de ferro para a produção do aço, e as cinzas volantes $(\mathrm{CV})$, resíduos da queima de carvão. A fim de reduzir as emissões no processo de queima nos fornos durante a produção do clínquer, foi adotado o uso de combustíveis alternativos, como a biomassa plantada, além do aumento da eficiência dos fornos, evitando perdas de calor. Porém, as previsões de crescimento da demanda por cimento fazem com que as medidas adotas sejam insuficientes (DAMINELI, 2013; WCA, 2017).

A adição de finos não-hidratáveis, denominados fíleres, substituindo parte do cimento na matriz cimentícia, pode contribuir para o aumento da eficiência dos ligantes, produzindo um material com menores quantidades de cimento e desempenho satisfatório. Os fíleres atuam no preenchimento dos vazios, colaborando com a redução do teor de água na mistura e, consequentemente, aumentando a resistência do material por meio da diminuição da porosidade. Para que o sistema clínquer-fíler funcione adequadamente, é necessário: 1) avaliar as características das partículas dos fíleres, como o formato e a granulometria, para evitar a formação de aglomerados, que exigem maiores adições de água; 2) garantir um comportamento reológico adequado, através da dispersão das partículas, proporcionando uma melhor trabalhabilidade com menor teor de fluido; 3) promover um empacotamento adequado, a fim de reduzir possíveis poros (DAMINELI, 2013).

O objetivo do presente trabalho foi explorar o potencial de substituição de parte do volume do cimento por fíleres inertes de quartzo em materiais cimentícios, visando reduzir o consumo de ligantes, como o clínquer, na matriz. Busca-se comprovar a eficiência do material produzido, através da relação entre seus desempenhos reológicos e mecânicos, e o consumo de cimento, a fim de demonstrar a viabilidade de aplicação do material com impacto ambiental reduzido na construção civil.

A dissertação foi estruturada a partir de uma revisão teórica, que apresenta abordagens sobre: 1) os problemas ambientais causados pela indústria de cimento, como o aquecimento global provocado pelas emissões de $\mathrm{CO}_{2}$, liberados pela queima das matérias-primas para a produção do clínquer; 2) questionamentos envolvendo as estratégias utilizadas pelas produtoras para redução das emissões, explicando o porquê não são efetivas para mitigação; 3) a proposta de redução do consumo de cimento, através da eficiência dos ligantes, junto à adição de fíleres inertes na matriz; 4) os parâmetros que devem ser estudados para garantir a eficiência dos 
ligantes; 5) os fundamentos que respaldam os experimentos utilizados. Posteriormente, são apresentados os capítulos experimentais, com a descrição dos materiais e métodos utilizados e as análises dos resultados e conclusões.

Os capítulos experimentais foram divididos em duas partes, a primeira foi destinada aos estudos feitos com as pastas, e contém: 1) análises das características das matérias-primas, como a composição granulométrica, a área superficial específica e a densidade real; 2) avaliações das características reológicas de pastas feitas com as matérias-primas puras e de misturas de cimento-fíler, observando o comportamento reológico em relação aos parâmetros de viscosidade (ensaio de Funil de Marsh) e tensão de escoamento (ensaio de espalhamento pelo minicone); 3) a determinação dos pontos de saturação (teor ótimo) de dispersante, através dos ensaios de reologia; 4) análises do tempo de trabalhabilidade das pastas produzidas em comparação com a convencional; 5) resultados dos ensaios de resistência à compressão dos corpos de prova; 6) cálculo do índice de eficiência das pastas.

A segunda parte foi destinada às análises dos ensaios feitos com as argamassas de cimento-fíler e cimento puro, e apresenta os resultados de resistência à compressão uniaxial e dos módulos de elasticidade determinados através da técnica de excitação por impulso e as análises de eficiência das argamassas produzidas. 


\section{IMPACTOS AMBIENTAIS DO CIMENTO E ESTRATÉGIAS PARA SUA MITIGAÇ̃̃O}

Este capítulo discute sobre o panorama atual da intensificação do aquecimento global, seus efeitos sobre a vida na Terra e a contribuição que o crescimento da produção do cimento pode trazer para o aumento do efeito estufa. Apresenta abordagens sobre as principais estratégias de mitigação adotadas pelas produtoras de cimento, discutindo os potenciais desses recursos. Por fim, discute a estratégia de otimização dos ligantes com adição de fíleres como método de diminuição do uso do clínquer em materiais cimentícios.

\subsection{AQUECIMENTO GLOBAL E PROJEÇÕES FUTURAS}

As mudanças climáticas são alvos de preocupação mundial e geram debates sobre formas de contenção e suas origens, que são ligadas ao aumento das emissões de gases de efeito estufa, principalmente o $\mathrm{CO}_{2}$, que representa cerca de $82 \%$ do total. A radiação solar aquece a superfície da Terra, sendo reemitida para o espaço, porém, os gases de efeito estufa apresentam forte absorção dos espectros infravermelhos, fazendo com que a maior parte dessa radiação fique presa na atmosfera, retendo o calor e elevando as temperaturas médias globais (DAMTOFT et al., 2008).

O clima da Terra se mantém propício à vida devido à presença de gases que ajudam a estabilizá-lo, dentre eles os mais importantes são o $\mathrm{CO}_{2}$ e o $\mathrm{H}_{2} \mathrm{O}$, que estão presentes em maior quantidade. A estabilização do $\mathrm{CO}_{2}$ na atmosfera é feita por ciclos orgânicos do carbono, como a fotossíntese realizada pelas plantas, e ciclos inorgânicos, como o ciclo carbonato-silicato, que é o principal mecanismo de equilíbrio. Esse ciclo depende das taxas de intemperismo, que aceleram com o aumento da temperatura, portanto as concentrações de $\mathrm{CO}_{2}$ tendem a cair à medida que há elevação da temperatura. Porém, esse mecanismo demora centenas de milhares de anos (KASTING; CATLING, 2003), sendo insuficiente para conter o aquecimento global provocado pelos seres humanos.

A concentração de gases de efeito estufa aumentou de $280 \mathrm{ppm} / \mathrm{m}^{3}$ antes da industrialização para $379 \mathrm{ppm} / \mathrm{m}^{3}$ em 2005, grande parte desse aumento está relacionado à queima de combustíveis fósseis, às mudanças de uso da terra e às emissões de poluentes industriais. As alterações climáticas resultam em: 1) comportamentos climáticos distintos e extremos, que variam com a localização geográfica, provocando períodos de seca prolongada, tempestades e ciclones; 2) aquecimento dos oceanos e o consequente derretimento das geleiras, 
elevando o nível do mar; 3) contaminação e alteração dos solos, prejudicando a agricultura e a vegetação; 4) doenças relacionadas à poluição do ar e das águas (INTERGOVERNMENTAL PANEL OF CLIMATE CHANGE - IPCC, 2007).

A fim de estimar as projeções futuras do aquecimento global, o IPCC (2007) criou modelos com diferentes bases quantitativas como desenvolvimento econômico, eficiência energética, população, entre outros, para estimar o nível das alterações climáticas a partir do ano 2000 até 2050. O volume das emissões foi considerado constante, com base nos dados obtidos no período entre os anos 1900 e 2000. Segundo as simulações feitas para o conjunto de cenários, a média de temperatura do planeta tende a subir $0,2^{\circ} \mathrm{C}$ por década, nas próximas duas décadas. A Figura 1 feita pelo IPCC mostra as estimativas feitas pelos modelos do aumento da temperatura média nos continentes até 2050.

Figura 1 - Anomalias nas temperaturas continentais, observadas de 1906 até 2005 e projeções até 2050.
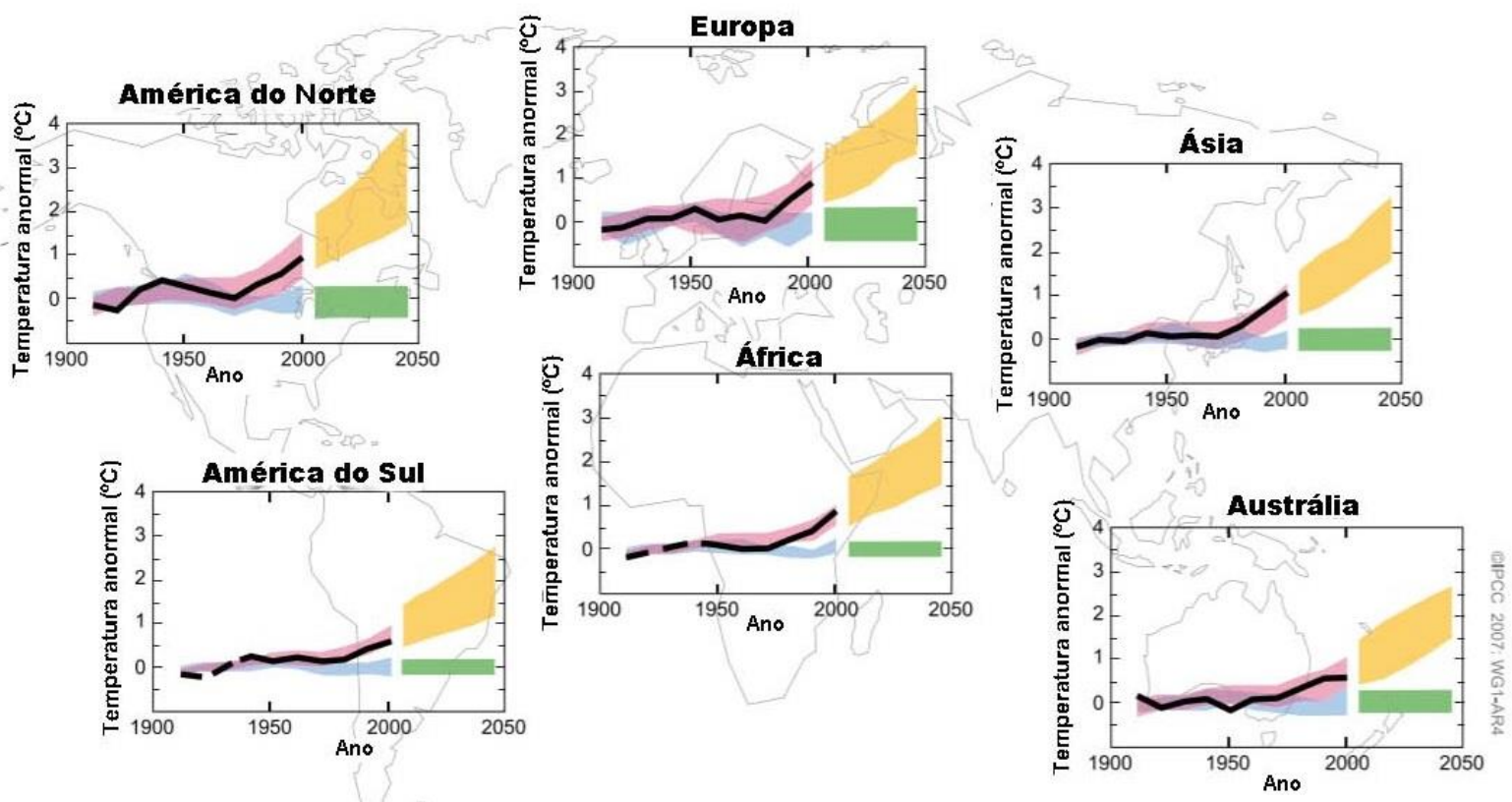

modelos usando apenas forças naturais

modelos usando forças naturais e antropogenicas

mudanças projetadas (modelo A1B)

observações

anomalias provocadas apenas por forças naturais em simulações

Fonte: IPCC (2007).

Segundo Jackson et al. (2017) a estabilização das emissões de $\mathrm{CO}_{2}$ mantida entre 2014 e 2016 não foi suficiente para conter o aquecimento global e será quebrada com um aumento em torno de $2 \%$ da poluição em 2017, com previsões de taxas superiores em 2018. Os 
pesquisadores apontam para um maior consumo de combustíveis fósseis na produção de energia primária, principalmente pela China e pela Índia, que causam impactos que desequilibram os esforços de diminuição das emissões feitos pelos demais países, como os europeus. As projeções de desenvolvimento econômico global feitas pela pesquisa sugerem aumentos expressivos nas emissões de gases de efeito estufa, alertando para a necessidade de medidas mais profundas e imediatas para manter a temperatura da Terra estável. A Figura 2 mostra a quantidade de $\mathrm{CO}_{2}$ global emitida de 1960 até 2017.

Figura 2 - Emissões de CO2 globais de 1960 a 2017.

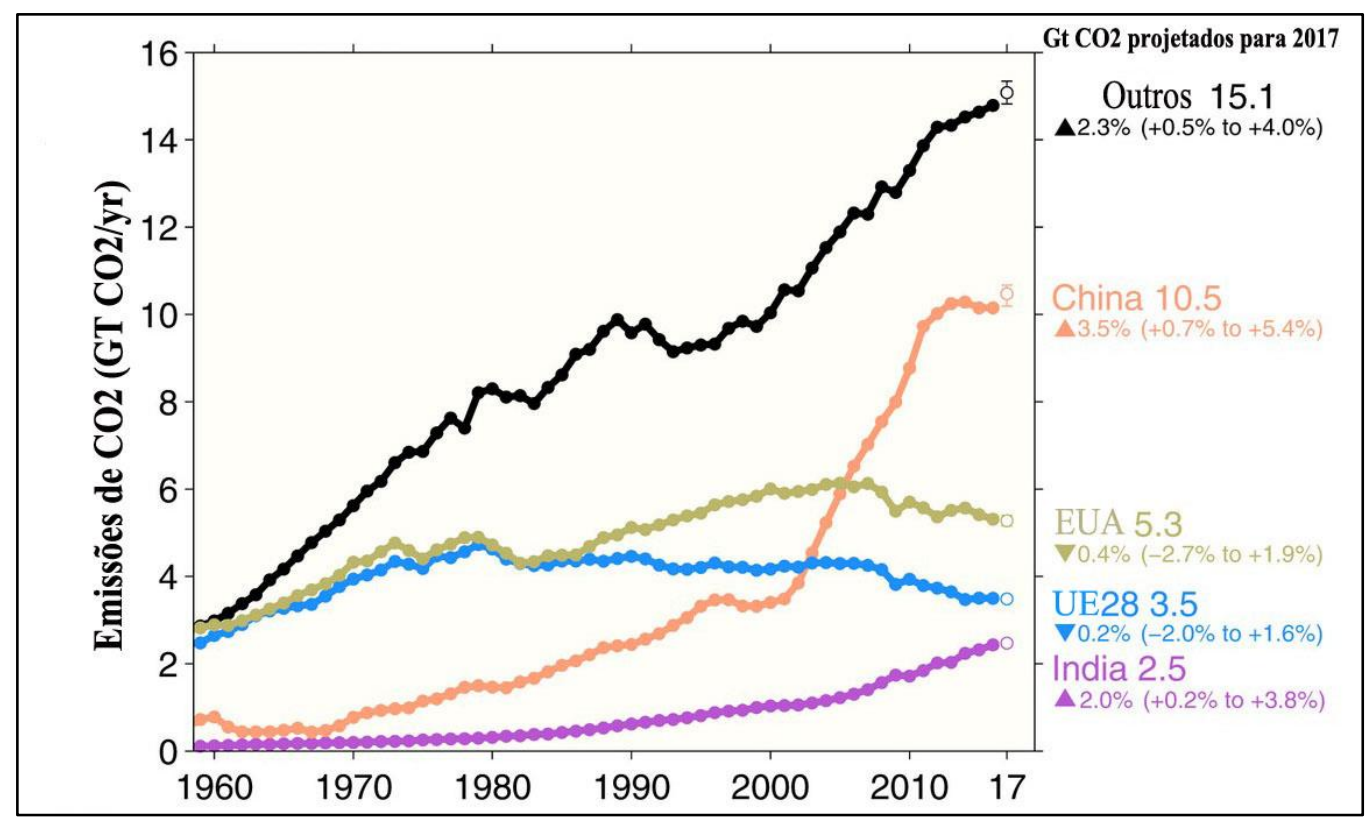

Fonte: www.cicero.oslo.no

De acordo com os dados publicados pelo International Energy Agency - IEA (2018), as emissões globais relacionadas à energia aumentaram cerca de 1,4\% em 2017, devido ao crescimento econômico global de 3,7\%, que elevou a demanda por energia em 2,1\% em 2017, preços de combustíveis fósseis mais baixos, e pouco investimento em eficiência energética. Apesar de ter ocorrido declínio das emissões no México, Reino Unido, Japão e EUA, resultado do aumento da utilização de energias renováveis, e redução da produção de aço nos EUA, o uso de combustíveis fósseis alcançou 70\% da demanda energética total do mundo, sendo a Ásia, responsável por 2/3 das emissões globais. A Figura 3 mostra os dados do aumento das taxas de $\mathrm{CO}_{2}$ por região do mundo de 2016 para 2017. 
Figura 3 - Aumento das emissões de CO2 por região de 2016 para 2017.

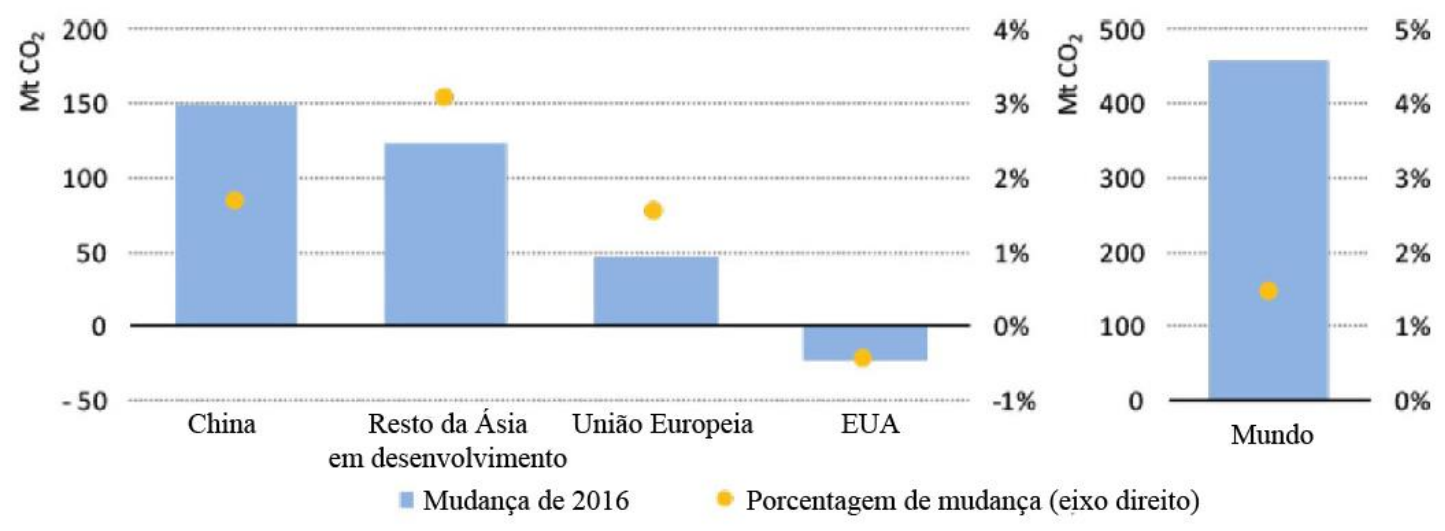

Fonte: IEA (2018)

\subsection{IMPACTOS AMBIENTAIS DA CADEIA DE PRODUÇÃO DO CIMENTO}

Depois da areia, o cimento é a matéria-prima mais utilizada no mundo, pois é o componente principal do concreto, material moldável, de baixo custo, capaz de atingir altas resistências e grande durabilidade. Entretanto, a indústria cimentícia é considerada a terceira maior emissora de $\mathrm{CO}_{2}$, correspondendo a cerca de $8 \%$ do total das emissões globais, com tendência a aumentar para 30\% em 2050 (LE QUÉRÉ et al., 2018; WORLD BUSINESS CONSIL FOR SUSTAINABLE DEVELOPMENT - WBCSD, 2009).

A maior parte dos poluentes emitidos advém do processo de calcinação do calcário, que equivale à maior parte das matérias-primas utilizadas na cadeia produtiva, e contém carbonato de cálcio $\left(\mathrm{CaCO}_{3}\right)$. Durante esta etapa, as matérias-primas são aquecidas a uma temperatura em torno de $1400{ }^{\circ} \mathrm{C}$, gerando a calcinação do $\mathrm{CaCO} 3$ que forma $\mathrm{CaO}$ e libera $\mathrm{CO}_{2}$, além de formar outros óxidos a partir da desidroxilação da argila, gerando o clínquer. No final do processo, o cimento Portland é feito através da moagem do clínquer com pequenas dosagens de gipsita (KJELLSEN; GUIMARAES; NILSSON, 2005).

A produção global de cimento aumentou 54\% entre 2000 e 2006, enquanto as emissões absolutas de $\mathrm{CO}_{2}$ aumentaram cerca de $42 \%$ (WBCSD, 2009). Segundo o relatório anual do Sindicato Nacional da Indústria do Cimento - SINC (2013), a produção mundial de cimento cresceu de $3,34 \times 10^{9}$ ton em 2010 para $3,70 \times 10^{9}$ em 2012, juntamente com o crescimento do consumo de $3,31 \times 10^{9}$ ton para $3,80 \times 10^{9}$. Em previsões feitas entre 2005 e 2050 pela WBCSD (2007), constam o aumento da produção mundial para um cenário pessimista, sendo 
$5,4 \times 10^{9}$ ton até 2050 com emissões de $5 \times 10^{9}$ ton de $\mathrm{CO}_{2}$, e para um cenário mais otimista de $4,40 \times 10^{9}$ ton, emitindo $2,52 \times 10^{9}$ ton.

O relatório elaborado pela United States Geological Survey - USGS (2018) mostra que os aumentos previstos anteriormente pela WBCSD foram subestimados, pois revela que a produção mundial em 2016 foi em torno de 4,10x109 ton, com estabilização em 2017. Entretanto, as taxas de produção de cimento tendem a subir, pois a recuperação econômica dos mercados desenvolvidos, como os EUA e alguns países europeus, e dos emergentes, principalmente a Índia, fez com que o consumo global de cimento aumentasse em torno de $1 \%$ em 2017 e tenha aumento estimado de 1,5\% em 2018. Estima-se que a demanda por cimento nos países desenvolvidos aumente 3\% em 2018 com maiores taxas nos próximos 7 anos (WORLD CEMENT ASSOCIATION - WCA, 2017). A Figura 4 contém previsões do crescimento do consumo de cimento de 2009 a 2019.

Figura 4 - Demanda global por cimento

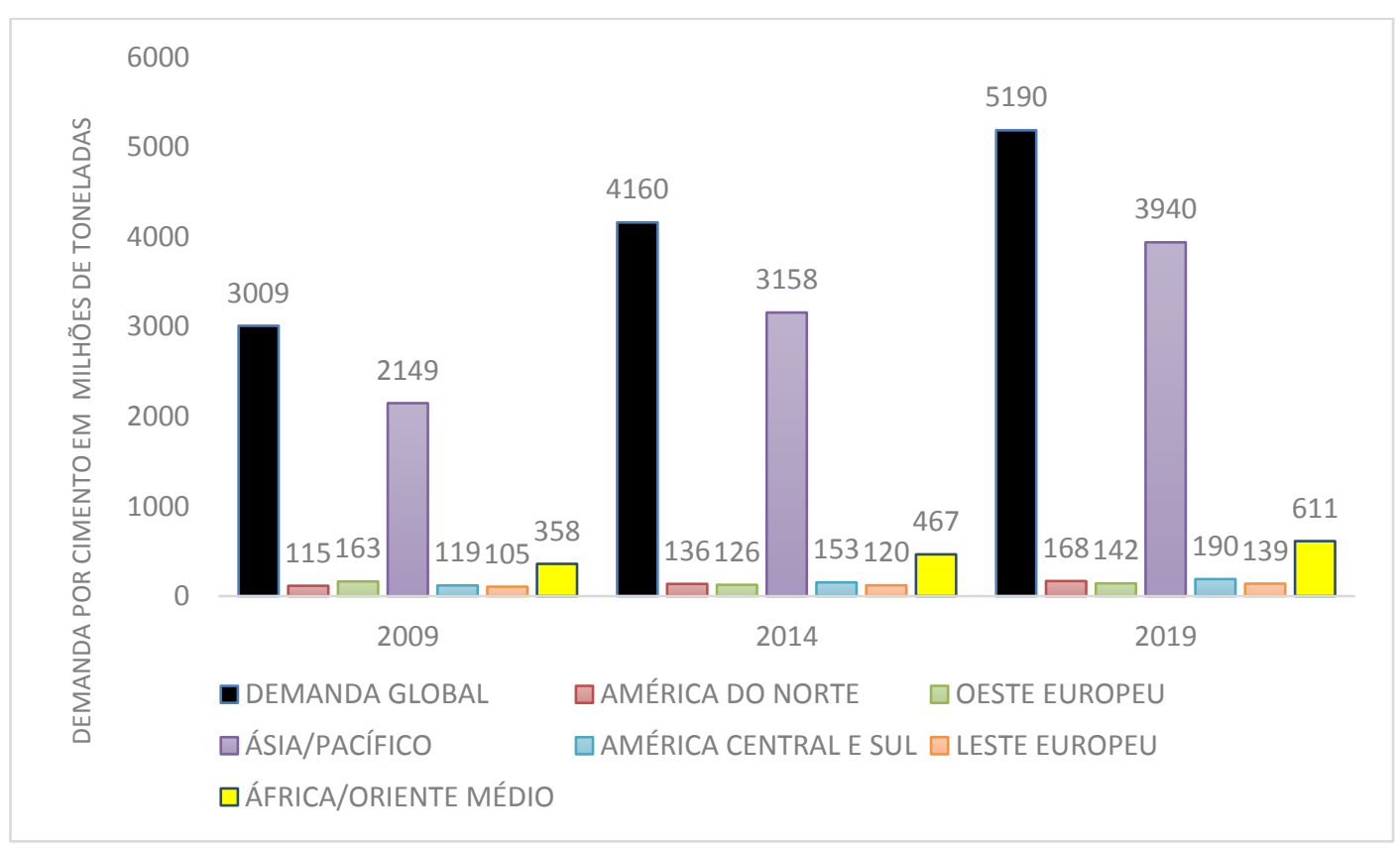

Fonte: The Freedonia Group, Inc (2015)

A Figura 5 mostra o gráfico feito pela WBCSD (2016) com os dados mundiais de $\mathrm{CO}_{2}$ emitidos por tonelada de cimento de 1990 até 2015, demonstrando uma queda nas emissões, devido às estratégias implantadas na produção, e uma estabilização de 2012 a 2015. 
Figura 5 - Quilograma de $\mathrm{CO}_{2}$ emitidos por tonelada de cimento produzido.

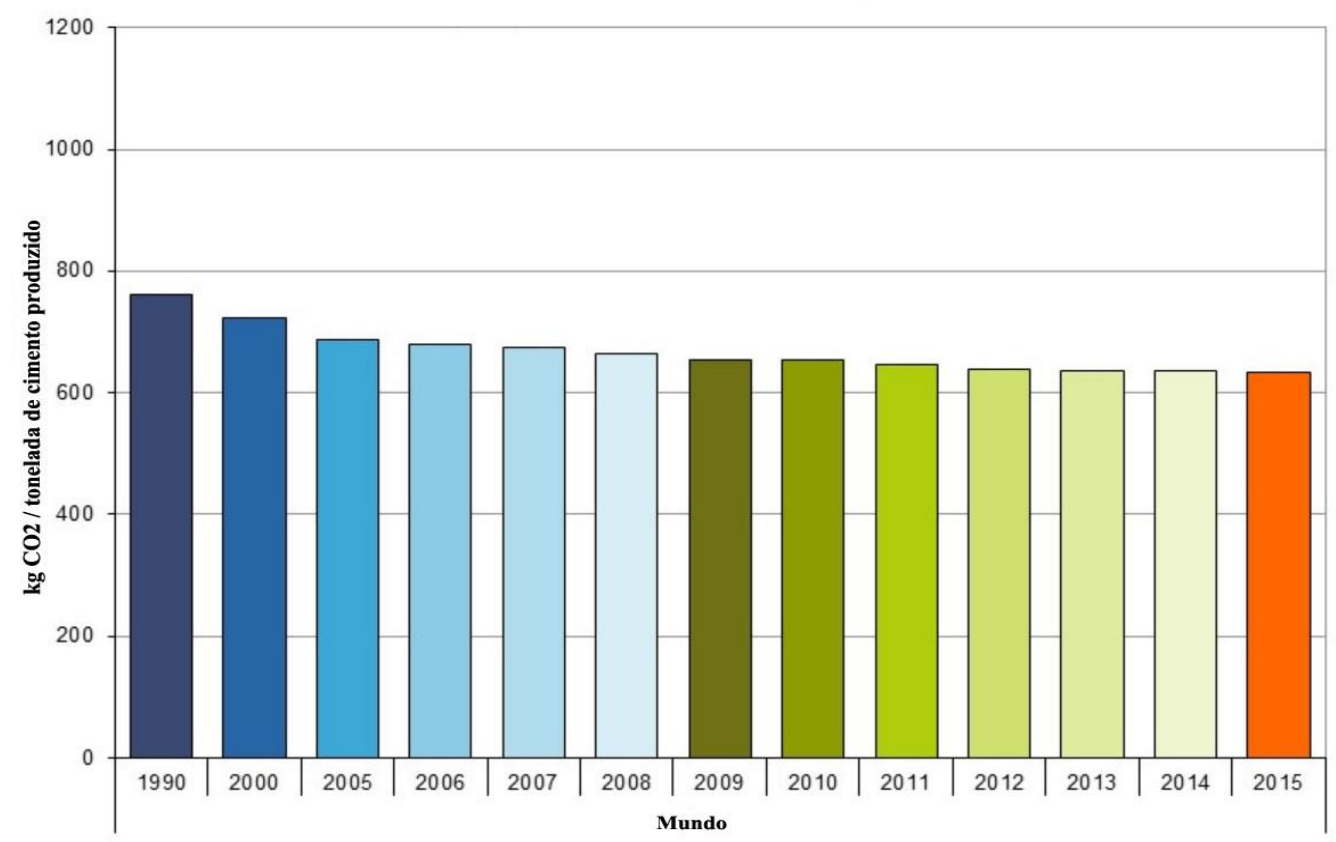

Fonte: WBCSD (2016).

A queda e estabilização da quantidade de $\mathrm{CO}_{2}$ emitida por tonelada de cimento produzido ocorreu, principalmente, devido à diminuição do teor de clínquer e à substituição dos combustíveis fósseis. Porém, o aumento estimado da demanda por cimento e concreto causará um desequilíbrio e as taxas de poluição voltarão a subir (DAMINELI, 2013). Portanto, é necessário investir em estudos que avaliem novas formas de redução das emissões relacionadas à indústria cimenteira, juntamente com as estratégias que já vêm sendo utilizadas.

\subsection{MITIGAÇÃO DAS EMISSÕES DE POLUENTES NA PRODUÇÃO DE CIMENTO}

Os esforços incorporados pelas indústrias são: 1) o uso de tecnologias mais eficientes no processo de produção; 2) a substituição do clínquer por adições minerais, que são resíduos provenientes de outras manufaturas, como as cinzas volantes e a escória de alto forno; e 3) o uso de combustíveis alternativos de emissão neutra, como a biomassa plantada, o gás natural e resíduos de outras indústrias (HUNTZINGER; EATMON, 2009).

\subsubsection{Eficiência energética na produção}

A eficiência dos fornos é a principal preocupação da indústria cimenteira durante a instalação, que dependem do preço da distribuição de energia da região em que está situada. Existem diversas tecnologias disponíveis que permitem a utilização mínima de 3GJ de energia 
por tonelada de clínquer, graças à substituição dos fornos que processam por via úmida por fornos com processamento via seca (WBCSD, 2009). Os fornos úmidos usam muita energia para evaporar a água, consumindo o dobro de energia que os fornos secos, porém o custo para troca dos equipamentos faz com que algumas produtoras continuem utilizando esse tipo de maquinário. Outras ações envolvem a utilização de isolantes térmicos mais eficientes nos fornos, a fim de reduzir perdas de calor e possibilitar a cogeração de energia (GARTNER, 2004).

Segundo Gartner (2004), o limite de eficiência térmica para um forno regulado adequadamente, usando matérias-primas previamente secas é de cerca de $3 \mathrm{GJ}$ de energia por tonelada de clínquer.

\subsubsection{Substituição do clínquer por adições minerais}

A substituição do clínquer por subprodutos reativos de outros processos industriais é o principal mecanismo adotado pelas indústrias cimentícias para reduzir as emissões de $\mathrm{CO}_{2}$ na produção do cimento, sendo as cinzas volantes (CV) e a escória de alto forno (EAF), as principais matérias-primas incorporadas (DAMINELI, 2013). A adição desses resíduos reduz o descarte industrial em regiões onde há produção e diminui a quantidade de clínquer utilizada na fabricação do cimento (HUNTZINGER; EATMON, 2009), porém com o aumento previsto da necessidade e consumo de cimento, para que o teor de substituição seja mantido, serão exigidas maiores disponibilidades desses subprodutos, que ocorre em menor proporção que a taxa de produção do cimento. (DAMINELI; JOHN, 2012; WBCSD, 2009).

A escória de alto forno, subproduto da indústria do aço, é alvo de disputas entre diversas indústrias no Brasil, além da cimenteira (LIMA, 2010), podendo transformar o resíduo em um produto com preço elevado devido à competitividade no mercado. É necessário destacar que não há disponibilidade de $\mathrm{EAF}$ e $\mathrm{CV}$ em alguns locais devido à distância das áreas produtoras, fazendo com que a poluição causada pela produção de cimento seja maior em algumas regiões (DAMINELI, 2013).

No Brasil a disponibilidade de adições é limitada por fatores geográficos e pela produção de cimento em escala inferior à demanda. Logo, considerando que a quantidade desses subprodutos é insuficiente para suprir um mercado que necessita de um aumento na produtividade, a quantidade de clínquer incorporada terá sua proporção aumentada, mesmo nos cimentos certificados e vendidos como produtos de baixo impacto (OLIVEIRA et al., 2014). Segundo Gartner (2004), levando em conta as médias mundiais, as quantidades de adições 
produzidas são insuficientes para serem incorporadas dentro dos limites estabelecidos pelas normas. Além disso, é previsível uma redução da disponibilidade desses resíduos, devido ao aumento da eficiência das termelétricas e da utilização de fornos de arco elétrico.

As adições ativas como as cinzas volantes e a escória de alto forno chegam para as indústrias cimenteiras com impacto ambiental nulo, segundo as técnicas atuais de Análise do Ciclo de Vida (ACV), justificado pelo fato de serem resíduos de outras indústrias. A EAF é considerada resíduo e passa por um processo de moagem para ser utilizada na produção de cimento, portanto os impactos da trituração e do transporte da EAF até as indústrias cimenteiras deveriam ser considerados (AMMENBERG et al., 2011). Além disso, com o crescimento da demanda, estes resíduos passaram a ter valor lucrativo, sendo considerados "subprodutos". Este fator leva ao questionamento de que é necessário alocar a esses materiais parte dos impactos ambientais dos processos industriais de origem (CHEN et al. 2010; DAMINELI, 2013).

Chen et al. (2010) fizeram testes para determinação dos impactos ambientais alocados na produção das EAF e CV, com dados sobre a alocação por massa e econômica comparados ao cimento sem adições. Os resultados mostraram que ao considerar as EAF e as CV como resíduos, os impactos gerados seriam menores que os do clínquer, porém na alocação por massa de EAF e CV, os resultados demonstraram impactos superiores aos do clínquer. $\mathrm{Na}$ alocação econômica, as EAF demonstraram menores impactos no aquecimento global que o cimento puro, no entanto os impactos ambientais como poluição da água são superiores. As CV apresentaram impactos no efeito estufa semelhantes ou superiores aos do cimento puro, pois são subprodutos de usinas de carvão, que emitem grandes quantidades de poluentes. A Tabela 1 mostra os dados de alocação de impactos obtidos.

Tabela 1 - Alocação de impactos nas EAF e CV

\begin{tabular}{c|cc}
\hline \multicolumn{1}{c}{ Adição } & Análise valor econômico & Análise em massa \\
\hline Escória de alto forno & $0,15 \mathrm{~kg} \mathrm{CO} / \mathrm{kg} \mathrm{EAF}$ & $1,39 \mathrm{~kg} \mathrm{CO} / \mathrm{kg} \mathrm{EAF}$ \\
Cinzas Volantes & $0,35 \mathrm{~kg} \mathrm{de} \mathrm{CO}_{2} / \mathrm{kg} \mathrm{CV}$ & $4,18 \mathrm{~kg} \mathrm{CO} / \mathrm{kg} \mathrm{CV}$ \\
\hline
\end{tabular}

Fonte: Chen et al. (2010).

\subsubsection{Cinzas volantes}

As cinzas volantes são subprodutos da queima do carvão, apresentando grandes quantidades de carbono em sua composição, e sua ação pozolânica está relacionada à presença de uma parcela de óxido de silício amorfo $\left(\mathrm{SiO}_{2}\right)$, que é altamente reativo. O carvão é um dos meios de produção de energia mais impactantes ao meio ambiente, desde sua extração até a 
queima. A exploração das jazidas causa interferência nos recursos hídricos, na vegetação nativa, no habitat dos animais e nas comunidades locais, e combustão para geração de energia emite gases como nitrogênio $\left(\mathrm{NO}_{X}\right)$, enxofre $\left(\mathrm{SO}_{X}\right)$ e $\mathrm{CO}_{2}$. A principal aplicação do carvão mineral é a geração de energia elétrica em termelétricas e em segundo lugar, a geração de calor em produções industriais. Porém, devido às pressões ambientais, estão sendo desenvolvidos processos tecnológicos que aproveitam o vapor aplicado na produção industrial na geração de energia elétrica (AGÊNCIA NACIONAL DE ENERGIA ELÉTRICA - ANEEL, 2008).

A Figura 6 mostra um esquema do processo produtivo das cinzas volantes na queima do carvão mineral.

Figura 6 - Resumo esquemático da produção das cinzas volantes na queima do carvão.

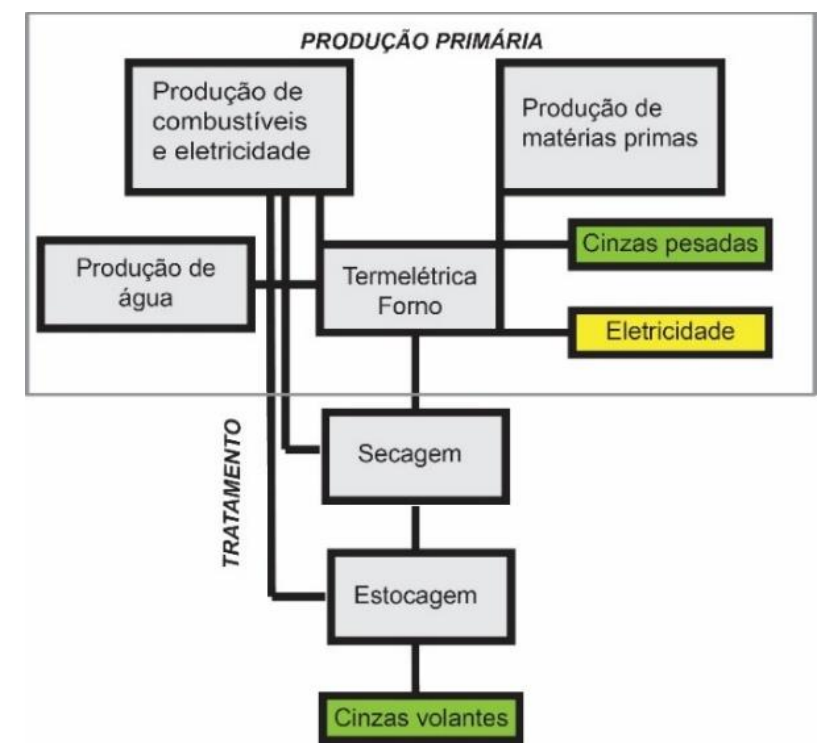

Fonte: Chen et al. (2010).

As reservas de carvão estão estimadas em $891 \times 10^{9}$ toneladas, segundo dados de 2015 , porém o consumo global de carvão em 2015 foi de $3,84 \times 10^{9}$ toneladas, com queda de $1,8 \%$ em relação a 2014 e a produção global foi de $3,83 \times 10^{9}$ toneladas, com redução de $4 \%$. A incongruência entre os dados de consumo e produção ocorre pelas diferenças de estoque entre os países e pelas disparidades nos cálculos dos dados relativos à oferta e à demanda de carvão. Os Estados Unidos, que estão entre os maiores produtores e consumidores de carvão do mundo (segundo maior produtor), tiveram queda de $12,7 \%$ do consumo e $10,4 \%$ da produção e a China, maior produtor mundial, teve queda de $2 \%$ na produção e de $1,5 \%$ no consumo. Assim, a visível queda da participação do carvão na geração de energia primária é consequência das restrições ambientais e dos impostos que estão sendo aplicados sobre as emissões de poluentes, fazendo com que os países busquem alternativas ambientalmente menos agressivas (BP GROUP, 2016). 
Pesquisas feitas por Hook et al. (2010) estimaram o futuro da produção global de carvão, levando em conta os volumes disponíveis, aspectos tecnológicos e socioeconômicos, desconsiderando as restrições ambientais. Os resultados obtidos demonstraram que a produção global apresenta tendência de crescimento nas próximas décadas, atingindo um pico em 2025, principalmente na China, Índia e Austrália, e sofrerá uma queda a partir de 2030. Caso fossem consideradas as restrições adicionais, a partir do cenário político atual, os volumes disponíveis para produção futura seriam inferiores aos relatados nessas estimativas.

Segundo Stewart; Kalyoncu (1999), aproximadamente $12 \%$ do carvão queimado é convertido em resíduos e as CV representam 6\% desse total gerado. No Brasil, o Rio Grande do Sul detém $89 \%$ do total de reservas, Santa Catarina com cerca de $10 \%$ e o Paraná com $1 \%$ (FUNDAÇÃO DE CIÊNCIA E TECNOLOGIA - CIENTEC, 2016). Dados obtidos pela CIENTEC (2016), estimam uma produção de cinzas volantes no Estado do Rio Grande do Sul de cerca de 1,5 milhões de toneladas/ano, sendo que aproximadamente $30 \%$ da CV gerada é comercializada, devido aos problemas de transporte pela distância entre locais de produção de $\mathrm{CV}$ e cimento. Embora a norma brasileira permita o uso de até $55 \%$ de $\mathrm{CV}$ no cimento, a quantia utilizada varia de 30-35\%, sendo que a parcela de CV utilizada na produção do cimento atinge a média de 12 mil toneladas por mês.

\subsubsection{Escoria granulada de alto forno}

A escória de alto forno tem como principais constituintes o óxido de silício $\left(\mathrm{SiO}_{2}\right)$ e óxido de cálcio $(\mathrm{CaO})$, podendo ser cristalina (escória bruta de alto forno), que não possui propriedades reativas, e amorfa (escória granulada de alto forno), que apresenta reatividade e é usada como componente do cimento junto ao clínquer (JOHN, 1995). A EAF é considerada subproduto da indústria de aço, formada no processo de redução do minério de ferro, que se resume na queima com carvão destilado em alto forno, removendo oxigênio do ferro para ligarse ao carbono. Nessa primeira etapa o ferro é transformado em ferro gusa, gerando a escória de alto forno. Na segunda etapa o ferro gusa é levado para refino para ser transformado em aço, gerando a escória de aciaria (AçoBrasil, 2016). A Figura 7 mostra as etapas de produção do ferro gusa, do aço e a geração de escórias. 
Figura 7 - Processo de produção do aço.

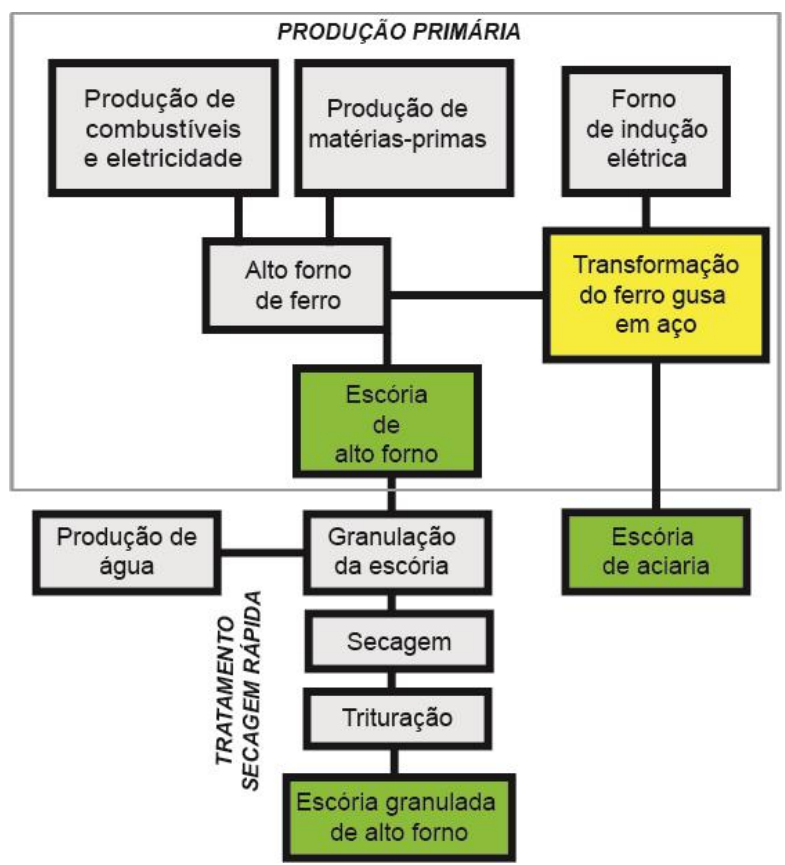

Fonte: Chen et al. (2010)

No atual cenário de aumento do aquecimento global, as indústrias do aço também vêm sendo pressionadas para redução dos impactos ambientais ligados à produção. Logo, as estratégias adotadas foram: 1) reaproveitamento dos gases gerados no processo de produção para geração de energia própria; 2) utilização de carvão vegetal, sendo a maior parte ( $86 \%$ em 2015) plantado pela própria indústria; 3) eficiência energética dos processos produtivos, reciclagem do aço e dos resíduos gerados; 4) reaproveitamento da água e captação de água da chuva (AÇOBRASIL, 2016).

Segundo o relatório de sustentabilidade da Aço Brasil de 2016, o total de resíduos gerados pela indústria do aço no Brasil foi de 20,2 milhões de toneladas em 2014 e 19,8 milhões de toneladas em 2015, sendo 40\% compostos por EAF em 2014 e 43\% em 2015. Do total de EAF gerada em 2015, 99\% foram vendidas para indústrias de cimento. Quanto à produção de aço, houve decréscimo de produtividade na Europa, África e nas Américas, porém o aumento de produção na Ásia, principalmente na China, rendeu um saldo produtivo mundial de $0,8 \%$ em relação a 2015. O Brasil apresentou queda de 9,2\% em 2016 comparado a 2015, devido à recessão econômica interna, que afetou principalmente o setor da construção civil (WORLDSTEEL, 2016).

A Figura 8 mostra as porcentagens de geração dos diferentes resíduos da indústria do aço em 2014 e 2015. 
Figura 8 - Geração de resíduos na indústria do aço.
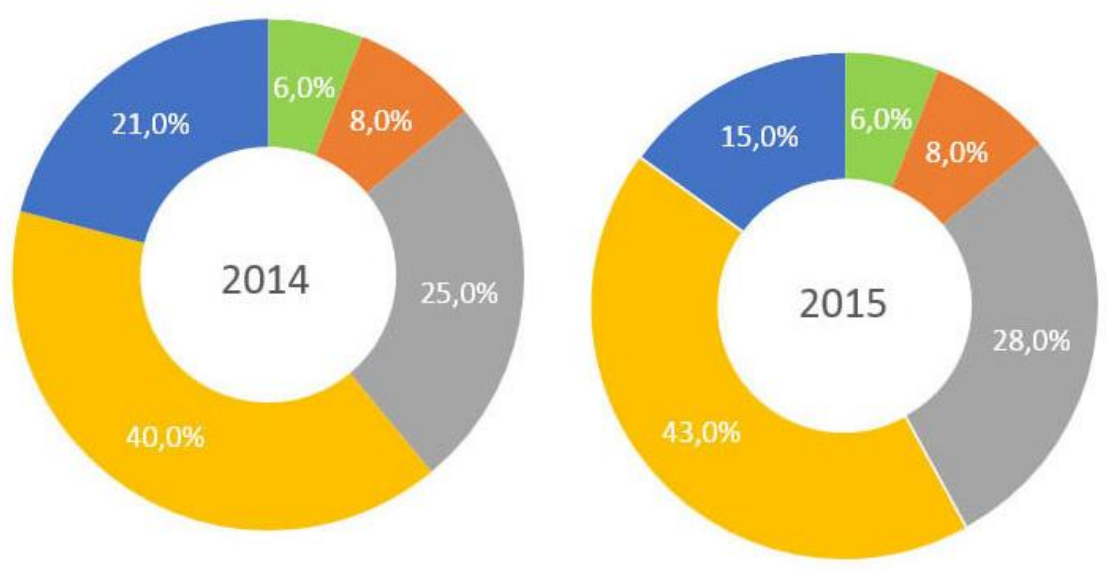

a LAMAS

- PÓSE FINOS

- ESCÓRIA DE ACIARIA

ESCÓRIA DE ALTO

FORNO

- OUTROS

Fonte: AçoBrasil (2016).

A Tabela 2 mostra o ranking dos 10 países que mais produzem aço, com dados de produção de 2015 e 2016.

Tabela 2 - Maiores produtores de aço

\begin{tabular}{ccccc}
\hline Rank & País & $\mathbf{2 0 1 6}(\mathbf{M t})$ & $\mathbf{2 0 1 5}(\mathbf{M t})$ & $\mathbf{\% ~ 2 0 1 6 / 2 0 1 5}$ \\
\hline $\mathbf{1}$ & China & 808,4 & 798,8 & 1,2 \\
$\mathbf{2}$ & Japão & 104,8 & 105,1 & $-0,3$ \\
$\mathbf{3}$ & Índia & 95,6 & 89 & 7,4 \\
$\mathbf{4}$ & EUA & 78,6 & 78,8 & $-0,3$ \\
$\mathbf{5}$ & Rússia & 70,8 & 70,9 & $-0,1$ \\
$\mathbf{6}$ & Coreia do Sul & 68,6 & 69,7 & $-1,6$ \\
$\mathbf{7}$ & Alemanha & 42,1 & 42,7 & $-1,4$ \\
$\mathbf{8}$ & Turquia & 33,2 & 31,5 & 5,2 \\
$\mathbf{9}$ & Brasil & 30,2 & 33,3 & $-9,2$ \\
$\mathbf{1 0}$ & Ucrânia & 24,2 & 23 & 5,5 \\
\hline
\end{tabular}

Fonte: Worldsteel (2016).

Os dados da Tabela 2 mostram que a disponibilidade de EAF varia de um país para o outro, além da queda de produção que afetou grande parte dos maiores produtores mundiais. Estes fatores indicam que a dependência da produção desses subprodutos em relação à demanda crescente por cimento é um obstáculo para alguns locais. Segundo Chen et al. (2010), a produção mundial de EAF em 2005 foi em torno de 150 milhões de toneladas e a de clínquer foi de 2500 milhões de toneladas. De acordo com Damineli (2013), a partir de 2020 o teor de substituição de clínquer por EAF não ultrapassará 10\%, estimando-se uma produção de 3×109 ton/ano de cimento e uma média de disponibilidade de EAF de 290x106 ton/ano. 


\subsubsection{Substituição dos combustíveis tradicionais}

A indústria cimenteira tradicionalmente fazia uso de óleo, carvão ou coque como combustíveis nos fornos, porém alternativas mais sustentáveis foram adotadas, devido ao baixo custo e à baixa emissão de poluentes durante a queima (WBCSD, 2016). O combustíveis alternativos mais utilizados são a biomassa plantada, que fixa carbono da atmosfera ao longo da vida e o gás natural (HABERT; ROUSSEL, 2009). Esta alternativa gera uma redução de até $33 \%$ das emissões totais no cimento nacional pela substituição completa dos combustíveis fósseis por biomassa com emissão neutra (LIMA, 2010).

A queima de combustíveis é responsável por $40 \%$ das emissões de $\mathrm{CO}_{2}$ na produção de cimento, o que demonstra que a substituição dos combustíveis tradicionais por alternativos traz resultados significativos. Porém, a disponibilidade de resíduos é divergente entre os países, o que faz com que as previsões de uso e a consequente diminuição das emissões provenientes da queima, sejam somente de até $24 \%$ na média mundial, não sendo suficiente para erradicação completa da poluição resultante dessa atividade (WBCSD, 2009). Dados levantados pela WBCSD (2016) mostram que houve uma redução considerável no uso de combustíveis tradicionais, caindo de $85 \%$ em 1990 para 23\% em 2014. O uso de combustíveis mais ricos em energia e pobres em carbono poderiam contribuir para a diminuição das emissões, como o gás natural, que é composto em maior parte por metano. Diante das previsões de aumento do preço dos combustíveis até 2050, torna-se atraente economicamente e em termos de sustentabilidade o uso do gás natural como combustível, pois está presente em abundância e tem efeitos mais significativos na redução das emissões, quando comparado aos combustíveis alternativos e à eficiência energética (WBCSD, 2009).

Além das barreiras geográficas, existem outros fatores que dificultam o uso dos combustíveis alternativos, como as propriedades químicas e físicas, que devem ser avaliadas antes da queima e a tendência à supervalorização desses produtos, com elevação dos preços (WBCSD, 2009). Segundo dados da WBCSD (2009), a tendência é que o uso dos combustíveis alternativos seja viável até 2030, quando sofrerá um aumento de custos de até $70 \%$ em relação aos combustíveis tradicionais, não havendo benefício econômico para continuidade do uso. Diante disso, é necessário buscar novas formas de reduzir as emissões relativas ao cimento.

\subsubsection{Captura e sequestro de carbono}

O processo se resume em capturar o $\mathrm{CO}_{2}$ emitido, transformá-lo em líquido e transportálo por tubulações até um local onde possa ser armazenado de forma segura e permanente. As 
principais opções são: em formações geológicas subterrâneas, como aquíferos, reservas de petróleo e gás, e no oceano (HOENIG; HOPPE; EMBERGER, 2007). A captura e sequestro de carbono aplicada à indústria é um procedimento que pode eliminar de maneira eficaz todo o $\mathrm{CO}_{2}$ gerado nos processos industriais. Entretanto, além de requerer um alto investimento em infraestrutura, instalação e de operação, que pode dobrar o preço do cimento no mercado, do ponto de vista técnico são necessários mais testes e experiências práticas para implementação, com prazo mínimo para 2020 (WBCSD, 2009).

\subsection{PASTA COM MENOR TEOR DE LIGANTES - O USO DOS FÍLERES}

Diante do cenário de pressões ambientais, do aumento previsto da demanda por cimento e da insuficiência das estratégias de mitigação por parte das indústrias cimenteiras, é necessário o aprofundamento de estudos focados no uso eficiente de cimento em materiais cimentícios, inclusive da substituição de parte do clínquer por fíleres ambientalmente menos agressivos e com grande disponibilidade. Para promover a eficiência dos ligantes, juntamente com a adição de fíleres, é necessário um controle reológico adequado, avaliando as características das partículas como a área superficial, densidade e formato, e as da pasta como o teor de água e a distância entre as partículas, parâmetros que se não controlados modificam o comportamento do sistema (DAMINELI et al., 2016).

A adição de fíleres não-hidratáveis na pasta cimentícia modifica as reações de hidratação das fases do clínquer, fenômeno denominado "efeito fíler". Os principais mecanismos promovidos por esse efeito são: 1) aumento da nucleação, pois os fíleres proporcionam superfícies suplementares para formação dos produtos de hidratação do clínquer (LOTHENBACH; SCRIVENER; HOOTON, 2011) e 2) diminuição dos vazios. Essas propriedades possibilitam bom desempenho mecânico e aumento da durabilidade do material (CASTRO; PANDOLFELLI, 2009). Logo, a mistura de finos na pasta cimentícia, desde que se promova um empacotamento adequado, aumenta a sua densidade através do preenchimento dos vazios, minimizando a diferença entre a densidade relativa da matriz e dos agregados, evitando a segregação do composto (PILEGGI et al, 2003).

Para Damineli (2013, p. 45), "a substituição de finos ligantes por finos inertes (conhecidos como fíleres), permite criar distribuições empacotadas que consomem pouca água e também têm diminuídos os teores de ligantes, o que aumenta a eficiência do seu uso". A 
adição de água no sistema cobre primeiramente a superfície dos grãos e posteriormente os vazios intergranulares. Logo, partículas que possuem grande área superficial ocasionam maiores volumes de vazios, demandando a inserção de maiores quantidades de fluido para aumentar a fluidez da mistura (VOGT, 2010). Logo, esse fator exige um aumento no teor de água, que ocasiona maior porosidade na pasta e diminui a resistência mecânica do material.

\subsubsection{Uso de fíler calcário}

$\mathrm{O}$ calcário, composto em maior parte por carbonato de cálcio $\left(\mathrm{CaCO}_{3}\right)$, é uma das matérias-primas do cimento e apresenta grande disponibilidade em todo o mundo, fato que comprova o potencial de uso desse material como fíler na produção de materiais cimentícios (DAMINELI, 2013). As reservas de calcário apresentam boa distribuição geográfica, presentes, principalmente, na China, Índia, Estados Unidos, Iran, Turquia e Brasil, que são os maiores produtores, segundo dados de 2014 (USGS, 2015; DEPARTAMENTO NACIONAL DE PRODUÇÃO MINERAL - DNPM, 2015). De acordo com o sumário mineral de 2015 elaborado pelo DNPM, a produção de calcário no Brasil em 2014 foi de 34 milhões de toneladas, quantidade muito inferior ao cimento, que em 2014 teve produção em torno de 71 milhões de toneladas.

Estudos feitos por Bentz (2005) verificaram os efeitos da substituição de até $20 \%$ de fíler calcário na hidratação do cimento. Os resultados mostraram que misturas com baixos teores de água impediram a formação de taumasita e a suscetibilidade à carbonação. Além disso, os fíleres aumentaram a taxa de hidratação do cimento devido às superfícies adicionais para a nucleação. Nesses sistemas, a substituição de fíleres calcários em materiais cimentícios é vantajosa em baixo fator água/sólidos $(<0,4)$, pois em pastas com cimento puro, para o mesmo teor de água, uma fração de partículas de clínquer permanece sem hidratação efetiva, exercendo apenas a função de preenchimento de poros. Em outro estudo, Bentz et al. (2009) avaliaram os efeitos do fíler calcário na retração autógena e no surgimento de fissuras em misturas cimentícias, analisando os efeitos da granulometria das partículas na mistura. Os resultados obtidos mostraram que, em sistemas com baixo fator água/sólidos, as deformações e fissuras foram reduzidas com a incorporação de fíleres com granulometria superior à do cimento.

\subsubsection{Uso de fíler de quartzo}

$\mathrm{O}$ quartzo, composto por dióxido de silício $\left(\mathrm{SiO}_{2}\right)$ com poliedro de coordenação cristalino, está presente em abundância no mundo inteiro, compondo em torno de $25 \%$ do volume da crosta continental, fazendo parte da estrutura de diversos tipos de rochas ígneas e 
sedimentares. É um mineral resistente às intempéries e ao ataque químico, possui elevada dureza, sendo encontrado em forma de grãos fragmentados em depósitos fluviais e litorâneos, além de ser um dos principais componentes dos solos (MENEZES, 2012). Existem três tipos de sílica cristalina, que variam com a temperatura e pressão: 1) o quartzo $\alpha$, mais abundante por ser a fase mais estável em temperatura ambiente e não apresenta pozolanicidade; 2) a tridimita e a cristobalita, de origem vulcânica, com estruturas moleculares metaestáveis e reativas, e se formam em ambientes de alta temperatura e pressão (HARIMA, 1997).

O uso de quartzo como fíler em concretos ainda é pouco estudado, logo diante do cenário de aumento da demanda por cimento e havendo grande disponibilidade de quartzo no setor nacional, é vantajoso para a economia e para a sustentabilidade verificar a viabilidade da incorporação desse mineral como fíler em materiais cimentícios. As normas técnicas estabelecem limites de adições de finos inertes, pois exigem um aumento no teor de água. Entretanto, um controle reológico adequado com o uso de dispersantes, garante que o material atinja resistências mecânicas satisfatórias sem exigir maiores quantidades de fluido (DAMINELI, 2013). Com base nesse efeito, Vogt (2010) observou que a substituição de parte do cimento por fíleres de quartzo, em misturas com baixo teor de água, pode proporcionar um significativo aumento na resistência à compressão, contudo isto demanda o uso adequado de dispersante.

Segundo Shihada e Arafa (2010), os concretos de alta performance são associados a uma matriz densa, caracterizada pelo uso de grandes volumes de partículas finas, que são geralmente fíleres de quartzo com granulometria máxima de $150 \mu \mathrm{m}$. Os autores avaliaram os efeitos da adição de finos de quartzo nas porcentagens de 20\%, 30\%, 40\% e 50\% na argamassa de cimento, concluindo que em misturas com baixo teor de água, conforme foi aumentada a porcentagem de fíler incorporada, maior foi o aumento da resistência à compressão.

Cherkaoui et al. (2010) estudaram os efeitos de cinco misturas feitas com variadas quantidades de sílica ativa, que apresenta reatividade por ser composta por $\mathrm{SiO}_{2}$ não cristalina (amorfa), finos de quartzo e aditivo superplastificante em concretos extrudáveis. Os resultados obtidos mostraram que a substituição parcial de sílica ativa por finos de quartzo proporcionou um aumento de $25 \%$ na resistência à compressão, $20 \%$ na resistência à flexão, para um teor constante de aditivo e uma diminuição na retração do material. Essas melhorias são em razão do melhor empacotamento de partículas da matriz na presença dos fíleres de quartzo, que permitiu a redução do teor de água no material. 
Rashad e Zeedan (2012) fizeram substituições em pastas de cimento Portland por porcentagens de 5\%,10\%, 15\% e 20\% de finos de quartzo, comparando com argamassas de cimento Portland puro. Os corpos de prova foram expostos a temperaturas de $200^{\circ} \mathrm{C}$ até $1000^{\circ} \mathrm{C}$, submetidos à choques térmicos e ensaios de resistência à compressão, que demonstraram que as misturas com maiores quantidades de fíleres de quartzo são mais resistentes a elevadas temperaturas e a choques térmicos que as de cimento Portland puro, além de obterem melhor desempenho de compressão.

O quartzo é um mineral considerado quimicamente inerte, porém Benezet e Benhassaine (1999) demonstraram que existem reações pozolânicas em fíleres de quartzo, que são perceptíveis em partículas de diâmetros inferiores a um "tamanho crítico" de $5 \mu \mathrm{m}$, logo compósitos com grandes quantidades de partículas de quartzo nessa granulometria possuem alta reatividade. Vogt (2010) misturou fíleres de quartzo de diferentes composições granulométricas ao cimento e avaliou o calor de hidratação, comparando a um composto convencional. Desta forma, demonstrou que os finos que possuem dimensões inferiores às partículas de cimento aceleraram a hidratação em maior velocidade que os fíleres de granulometrias equivalentes que, ainda assim, produziram uma aceleração superior à mistura sem adições.

\subsubsection{Desafios toxicológicos}

Um problema corrente sobre o uso de finos de quartzo como material é em relação à saúde humana, pois secos podem causar silicose, doença pulmonar obstrutiva crônica, câncer de pulmão, insuficiência renal e aumento do risco de tuberculose pulmonar (TERRA; SANTOS, 2006). Existem inúmeras publicações sobre doenças autoimunes em trabalhadores que foram expostos ao pó de quartzo ou à sílica cristalina, como esclerodermia, artrite reumatoide e lúpus eritematoso sistêmico (WORLD HEALTH ORGANIZATION - WHO, 2000). A exposição ocupacional se dá pela inalação de poeira, que pode ser depositada em variados pontos do sistema respiratório dependendo da dimensão da partícula. O limite de exposição recomendado pela National Institute for Occupational Safety and Health é de $0,05 \mathrm{mg} / \mathrm{m}^{3}$ de quartzo como poeira respirável para 40 horas semanais de trabalho (UNIVERSIDADE DO ESTADO DO RIO DE JANEIRO - UERJ, 2010).

De acordo com Beltrame et al. (2010), o equipamento de proteção individual serve como barreira entre um ambiente com condições nocivas e o trabalhador, sendo empregado em situações nas quais as medidas de proteção coletiva são insuficientes ou em emergências. 
Segundo pesquisas feitas pelo autor, as empresas se satisfazem apenas com o fornecimento de máscaras de proteção mal dimensionadas e impróprias, não havendo conhecimento prévio sobre os limites de exposição e equipamentos de proteção adequados para o trabalhador, estabelecidos pela vigilância. Este estudo levou em consideração a sílica cristalina, porém os demais minerais devem seguir os mesmos cuidados, pois também trazem problemas à saúde humana.

Segundo dados obtidos pelo Ministério da Saúde, a porcentagem de trabalhadores expostos no Brasil teve uma redução de apenas 0,4\% de 1985 para 2007. Embora possam ser prevenidos, os problemas provocados pelo contato com a sílica continuam afetando a saúde dos operários, principalmente nos países pobres por insuficiência de programas de controle e vigilância que identifiquem situações de riscos, limitando e controlando as atividades. Entre as medidas adotadas estão a modificação dos processos para evitar a disseminação de poeiras, o uso de proteções contra a inalação e a utilização de métodos úmidos (UERJ, 2010). Portanto, o uso de quartzo em indústrias é restrito e para possibilitar a sua aplicação, o pó de quartzo pode ser umidificado e utilizado em forma de pasta (VOGT, 2010).

\subsubsection{Desafios científicos e tecnológicos}

É necessário salientar que a complexidade em lidar com o quartzo é resultante dos variados tipos existentes, com características físicas e mecânicas particulares, que inclusive sofrem alterações conforme as suas formas e dimensões granulométricas. Além disso, a possibilidade de reatividade do quartzo em granulometrias finas vem sendo alvo de muitas dúvidas. Também será necessária uma adaptação das tecnologias industriais para manipular e caracterizar o material, a fim de possibilitar sua aplicação e manufatura com qualidade e segurança para os usuários e operários industriais.

Alguns pesquisadores mencionam o fato de o mineral possuir características expansivas quando submetido a elevadas temperaturas, e ao dilatar resulta em fraturas nas regiões próximas aos agregados. Segundo Bentz (2005), o quartzo possui um elevado coeficiente de expansão térmica, devido à transformação de quartzo $\alpha$ para quartzo $\beta$ de menor densidade, quando atinge a temperatura de $573^{\circ} \mathrm{C}$. Diante desse fator, são necessárias análises termogravimétricas para avaliar o comportamento dos materiais com adições de fíleres de quartzo, quando expostos a situações de incêndio.

Rickard; Gluth; Pistol (2016) compararam as microestruturas de dosagens de concretos geopoliméricos de cinzas volantes com adição de quartzo e sem adições, que foram expostas a temperaturas de até $750^{\circ} \mathrm{C}$. Os resultados mostraram que a desidratação por capilaridade causou 
fratura e perda de resistência em temperaturas menores que $300^{\circ} \mathrm{C}$, sendo esse efeito mais severo nos corpos de prova com finos de quartzo. Porém, verificou-se que a floculação de partículas gerada pelos fíleres promoveu a cicatrização das fissuras nas amostras, permitindo a recuperação da resistência com desempenho superior ao concreto convencional.

É importante ressaltar que as características granulométricas apresentam divergências de formato e área superficial que necessitam de avaliações, pois são fatores que influenciam na porosidade da matriz, podendo exigir maiores teores de água, que alteram a resistência mecânica e a durabilidade do material. Ou seja, o controle reológico adequado e o conhecimento das particularidades físicas das matérias-primas, possibilitam a redução da quantidade de água e define o máximo de fíleres que podem ser acrescentados na mistura, não sendo correto estabelecer limites de substituições dessas adições (DAMINELI et al., 2016). 


\section{COMPORTAMENTO REOLÓGICO DAS SUSPENSÕES}

A reologia estuda o escoamento e a deformação de suspensões e líquidos, após a aplicação de uma tensão. Isaac Newton definiu a reologia como a relação entre a tensão aplicada no material e as características do fluxo no decorrer do tempo. No presente trabalho, são abordados os comportamentos reológicos de suspensões de partículas, que foram avaliados através dos ensaios de espalhamento pelo minicone (tensão de escoamento) e escoamento pelo Funil de Marsh (viscosidade).

O comportamento reológico de uma suspensão é influenciado pelo rompimento das forças de interação entre as partículas, ao serem submetidas a uma tensão de cisalhamento. Logo, para que a adição de fíleres na pasta cimentícia garanta fluidez e trabalhabilidade adequadas, é necessário avaliar os seguintes fatores: caracterização das matérias-primas, visando a diminuição do teor de água para não afetar o desempenho mecânico do material; e o estudo do comportamento reológico para determinar o teor ideal de dispersante, garantindo a estabilidade da mistura no tempo de aplicação sem grandes aumentos no custo de produção (DAMINELI, 2013). Diante disso, este capítulo tem como objetivo apresentar os principais conceitos dos parâmetros que influenciam o comportamento reológico das suspensões, além dos ensaios utilizados para avaliação da reologia.

\subsection{DISPERSÃO DE PARTÍCULAS: CONCEITOS}

As partículas do cimento, ao entrarem em contato com a água, apresentam tendência à floculação, retendo parte do fluido que seria utilizado para hidratação da superfície das partículas e fluidificação da matriz. Assim, a adição de dispersantes nas pastas impede a formação de aglomerados e melhora a fluidez, garantindo uma melhor interação entre a água, o cimento e os fíleres por manter as partículas afastadas e conservadas num certo intervalo de dispersão. Além disso, suspensões corretamente dispersas permitem concentrações de sólidos superiores, favorecendo o empacotamento, a diminuição do teor de água e, consequentemente, o aumento da resistência do material (CASTRO; LIBORIO; PANDOLFELLI, 2011).

Para garantir o funcionamento do sistema clínquer-fíler, deve-se determinar o teor mínimo de água a ser inserido para preencher os poros existentes entre as partículas e afastálas, possibilitando a movimentação da suspensão (DAMINELI, 2013). Entretanto, partículas finas tendem a sofrer floculação através do desequilíbrio entre as cargas elétricas das 
superfícies, que geram forças atrativas, alterando a distribuição granulométrica e impedindo o fluxo das partículas menores (OLIVEIRA et al., 2000). Além disso, a formação de aglomerados gera vazios que podem reter água e dificultam a hidratação, as reações entre as superfícies dos grãos com a pasta, e a fluidez da mistura (AÏTCIN, 2000).

Assim, para evitar a floculação dos finos na suspensão, as forças de repulsão devem superar as forças de atração superficiais. Para isso, torna-se necessário o uso de dispersantes, que evitam a floculação e mantêm a estabilidade do sistema, minimizando o teor de água necessário para atingir fluidez e garantir misturas trabalháveis (CASTRO; PANDOLFELLI, 2009). A perda de dispersão pode comprometer a eficiência dos sistemas clínquer-fíler, devido aos seguintes fatores: diminuição dos efeitos do dispersante em manter as partículas afastadas, alteração do equilíbrio entre as cargas elétricas pelo aumento da dissolução de íons, e reações de hidratação que dão início ao endurecimento da suspensão (DAMINELI, 2013).

\subsubsection{Características das Partículas}

A formação de aglomerados nas suspensões pode ser resultado da atuação de forças de atração eletrostáticas, por meio do desequilíbrio entre as cargas superficiais das partículas, e pela atuação das forças de "Van Der Waals", originadas por dipolos elétricos no núcleo das partículas. Materiais muito finos, ao serem adicionados em meio líquido, tendem a aglomerar, devido à menor atuação das forças de massa em relação às demais, assim partículas com elevada área superficial acentuam a atuação de forças de superfície (eletrostáticas), se movendo de modo rápido e aleatório. O movimento desordenado das partículas na suspensão, provoca colisões que propiciam a floculação, atrapalhando as linhas de fluxo e aumentando a viscosidade (LYRA, 2010; OLIVEIRA et al. 2000).

A adição de finos na pasta cimentícia modifica a distribuição granulométrica, proporcionando superfícies adicionais para nucleação e aceleram a hidratação do clínquer, aumentando a resistência mecânica do material nas primeiras idades. Além disso, os fíleres preenchem os vazios intergranulares e liberam a água aprisionada, contribuindo para a melhoria da trabalhabilidade, aumento da densidade e da compactação do material (ADJOUDJ, 2015). Entretanto, esse efeito depende da atividade das superfícies das partículas dos fíleres e do cimento na suspensão, da afinidade entre as composições químicas e físicas das matériasprimas, sendo intensificado na presença de materiais mais finos e com menores áreas superficiais (ESPING, 2008). 
A área superficial é um dos principais parâmetros para avaliar o teor de água requerido na suspensão, porém é importante analisar a morfologia dos grãos. Partículas com formato irregular exigem maiores quantidades de água do que fíleres com formatos arredondados ou angulares (GALLIAS; BIGAS; ALI, 2000). A porosidade e a rugosidade também aumentam a área superficial, o que contribui para o aumento da viscosidade e da tensão de escoamento da suspensão, exigindo maiores teores de fluido para atingir a trabalhabilidade adequada e, consequentemente, reduzindo a resistência mecânica do material (ESPING, 2008).

Em relação à influência granulométrica Bessa, Bigas e Gallias (2004), fizeram experimentos com argamassas, verificando a influência da finura das partículas e das taxas de substituição do cimento por fíler, no aumento dos teores de água e dispersantes para uma consistência fixa. Em misturas sem dispersante, a adição de baixas dosagens de finos com dimensões maiores promoveram melhorias no empacotamento e atingiram a trabalhabilidade pré-fixada com menores quantidades de água. Os fíleres ultrafinos otimizaram o empacotamento em dosagens inferiores a 30\%; porém, em quantidades superiores, aumentaram o teor de água na mistura. Na segunda etapa, o teor de água foi mantido constante e o dispersante foi adicionado, sendo constatado que a modificação do teor de água induzida pelos efeitos granulométricos é diretamente proporcional à necessidade de dispersante para conter a variação do teor de água.

A melhoria da trabalhabilidade, do empacotamento e da resistência mecânica do material com fíleres depende da quantidade, do tipo, da área superficial e da finura das adições (BESSA; BIGAS; GALLIAS, 2004). Caso os efeitos da adição de fíleres nos materiais cimentícios não sejam avaliados adequadamente, podem ocorrer comportamentos reológicos inesperados por meio da alteração das forças eletrostáticas, através da influência da sua origem mineralógica e das cargas de superfície. Entretanto, para controlar a necessidade de maiores teores de água na matriz e promover comportamentos reológicos satisfatórios, é necessário determinar o teor ótimo do dispersante, que anula os polos de carga inversa e evita a atuação de forças atrativas (DAMINELI, 2013) 


\subsubsection{Dispersantes e seus mecanismos}

Conforme visto anteriormente, as propriedades reológicas das suspensões são dependentes do tipo e quantidade de aditivo dispersante adicionado, tensão e tempo de cisalhamento empregados à mistura, características das partículas e distribuição granulométrica (LIMA, 2006). Para propiciar a hidratação de todos os grãos na pasta, a distribuição homogênea de água na mistura e a consequente diminuição do teor de água incorporado, é necessário manter as partículas dispersas com o uso de um dispersante adequado para o tipo de cimento utilizado. Além disso, a fluidez pode ser distinta utilizando-se o mesmo dispersante em variados tipos de cimento, ou provocar efeitos diferentes com a variação do tipo de aditivo para um mesmo cimento (RAMACHANDRAN¹, 1984 apud LIMA, 2006).

Os variados efeitos dos dispersantes na fluidez, são devido ao mecanismo de repulsão provocado por cada tipo. Os dispersantes podem originar forças de repulsão através dos mecanismos de: 1) desenvolvimento de cargas superficiais nas partículas (eletrostático), 2) adsorção de cadeias poliméricas na superfície das partículas, através do impedimento físico (estérico), 3) adsorção de cadeias poliméricas com grupos ionizáveis (eletroestérico) (ORTEGA et al., 1997). A Figura 9 retrata a forma de estabilização de suspensões dos mecanismos citados.

Figura 9 - Mecanismos de estabilização de suspensões.
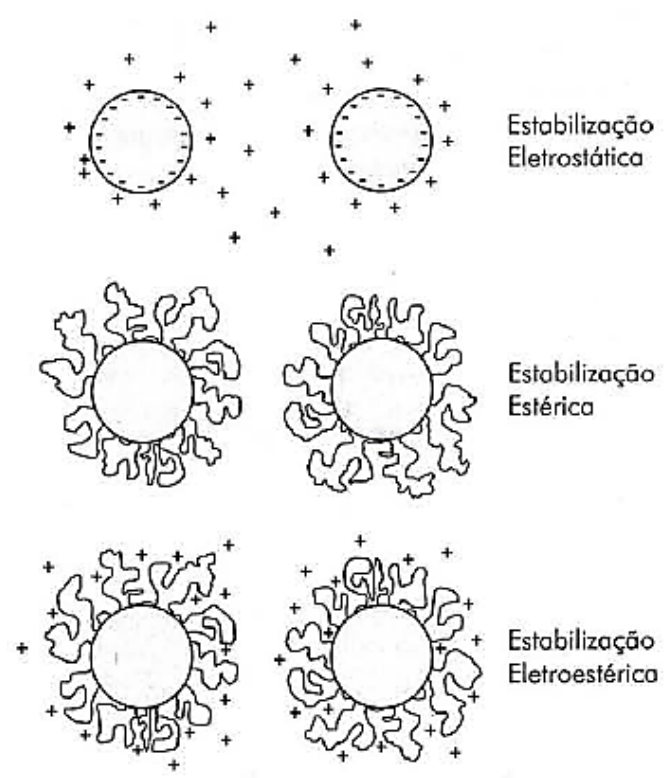

Fonte: Adaptado de Oliveira et al. (2000)

${ }^{1}$ RAMACHANDRAN, V. S. Concrete admixture handbook: properties science and technology. Canada: Noyes Publication, p. 1-53, 1984. 


\subsubsection{Dispersantes eletrostáticos}

A estabilização eletrostática ocorre pela adição de dispersantes que induzem a formação de uma camada dupla de elétrons em torno das partículas, com carga oposta à da superfície, evitando a floculação. A estabilidade da suspensão é controlada através da formação de um potencial elétrico de repulsão entre as partículas e pela espessura da camada dupla dos contraíons, gerados pelos dispersantes (LYRA, 2010).

\subsubsection{Dispersantes estéricos}

A estabilização estérica ocorre pela adsorção de cadeias poliméricas na superfície das partículas, cuja cadeia molecular dificulta a aproximação e a floculação por impedimento físico. Porém, se as camadas de dispersantes forem muito espessas, uma mesma cadeia polimérica pode ser adsorvida na superfície de mais de uma partícula. Esse fator provoca a diminuição da entropia do sistema, devido à interpenetração de camadas que faz com que se enrolem e se unam (OLIVEIRA et al., 2000). Além disso, cadeias poliméricas muito grandes mantêm as partículas muito afastadas, gerando poros que demandam maior adição de água ou de finos para preenchê-los. Para uma dispersão adequada, deve-se evitar a sobreposição das camadas de dispersante, que podem provocar repulsão excessiva, travando o sistema ou gerando aglomerados, devido às possíveis ligações entre as camadas sobrepostas (DAMINELI, 2013).

As vantagens do uso de dispersantes estéricos são: 1) não sofrem influência da concentração iônica do fluido, pois não envolvem a repulsão induzida pela formação de potenciais elétricos; 2) permitem redispersão em caso de floculação, pois são termodinamicamente estáveis, ao contrário do mecanismo de dispersão eletrostática, que mantém os aglomerados no estado de menor energia, dificultando a redispersão (OLIVEIRA et al., 2000).

\subsubsection{Dispersantes eletroestéricos}

No mecanismo eletroestérico, ocorre adsorção de cadeias poliméricas com formação de íons na superfície das partículas. Logo, além da barreira estérica, que impede a floculação através do distanciamento entre as partículas, há o efeito de estabilização pela indução de um potencial elétrico repulsivo, devido à dissociação dos grupos ionizáveis no meio líquido (OLIVEIRA et al., 2000). 


\subsubsection{Viscosidade e Tensão de Escoamento}

A caracterização reológica de um fluido envolve a sua taxa de deformação em relação ao tempo, essas relações apresentam variações complexas, conforme se afastam de um comportamento ideal. De acordo com o modelo das lâminas de fluido paralelas proposto por Isaac Newton, a força (F) aplicada em uma das lâminas provoca uma diferença de velocidade de deformação ao longo de uma distância (dx). Essa força é denominada tensão de cisalhamento e a diferença de velocidade ao longo da distância é conhecida como taxa de cisalhamento (gradiente de velocidade). A viscosidade do fluido é a constante de proporcionalidade entre a tensão de cisalhamento aplicada e a taxa de cisalhamento, sendo equivalente à resistência imposta pelas partículas ao fluxo da suspensão (OLIVEIRA et al., 2000).

A Figura 10 mostra o modelo de lâminas paralelas proposto por Newton e a variação das velocidades com a distância entre elas.

Figura 10 - Modelo de lâminas paralelas de Newton: duas lâminas movendo-se com velocidades distintas na mesma direção.

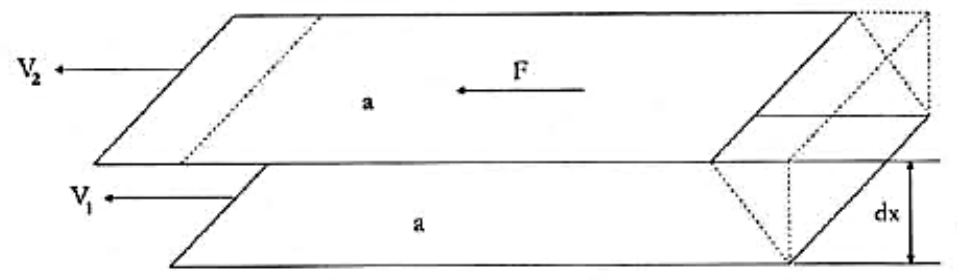

Fonte: Oliveira et al. (2000).

A tensão de escoamento é originada por estruturas de partículas aglomeradas na suspensão, sendo força mínima de cisalhamento necessária para romper esses aglomerados. Essa energia mínima mantém as partículas levemente atraídas entre si e em equilíbrio, fazendo com que permaneçam aglomeradas. Se as tensões aplicadas forem inferiores a essa tensão de escoamento, o fluido não escoa e não flui. Logo, a tensão de escoamento é um parâmetro reológico diretamente proporcional à força mínima imposta para desestruturar essas aglomerações de partículas mais brandas (OLIVEIRA et al., 2000). Experimentalmente, utilizase o ensaio de espalhamento pelo minicone para analisar a tensão de escoamento das pastas, verificando o tempo e o diâmetro de espalhamento atingido, através da força peso do próprio material.

De acordo com Schramm (2006) "a medida de viscosidade requer a definição dos parâmetros envolvidos no fluxo". Assim, é necessário fixar condições de ensaio que 
possibilitem a avaliação adequada das características do fluxo. Desse modo, o grau de viscosidade depende dos seguintes fatores: 1) natureza físico-química das partículas, como a granulometria, o formato e a área superficial específica; 2) taxa de cisalhamento aplicada, que influencia no grau de viscosidade do material; 3) o tempo de cisalhamento a que a mistura foi submetida; 4) temperatura e pressão; 5) o campo elétrico que atua entre as partículas na suspensão; 6) o peso molecular e a concentração das moléculas de dispersante ; 7) a dimensão da camada de dispersante em torno das partículas; 8) a concentração volumétrica de sólidos; (OLIVEIRA et al., 2000; SCHRAMM, 2006).

O efeito dos fíleres sobre a viscosidade na presença de dispersantes varia com: 1) a distribuição granulométrica, que pode gerar diferentes empacotamentos e quantidades de vazios; 2) área superficial das partículas, que podem sofrer maiores influências de forças de superfície e tendência à floculação; 3) o formato das partículas, pois formatos irregulares podem comprometer o empacotamento, gerando vazios, além de provocarem maiores colisões, que contribuem para o aumento da viscosidade. (NEHDI; MINDESS; AÏTCIN, 1998).

A fluidez da suspensão se torna mais rápida com a diminuição da viscosidade, portanto para que a mobilidade do sistema clínquer-fíler atinja uma trabalhabilidade satisfatória para o tempo de aplicação, é necessário alcançar o limite de viscosidade, utilizando um teor mínimo de água para garantir um bom desempenho mecânico do material (DAMINELI, 2013). Experimentalmente, utiliza-se o Funil de Marsh para determinar o teor ótimo de aditivo para um determinado teor de água, a fim de se obter o limite máximo de viscosidade da matriz.

De acordo com Damineli (2013) o controle da viscosidade da pasta pode ser feito por meio da: 1) caracterização das matérias-primas, com a avaliação da área superficial e da morfologia, pois podem gerar cargas superficiais que aumentam a viscosidade, exigindo maior teor de água; 2) dispersão das partículas, através da determinação do teor de dispersante ideal, visando a máxima fluidez com o mínimo de fluido; 3 ) dosagem correta das matérias-primas e dos ligantes que compõem a mistura, 4) empacotamento das partículas, de forma que preencha os vazios e permita a inserção do mínimo de água possível.

\subsubsection{Comportamentos reológicos}

Os fluidos Newtonianos são definidos como aqueles que apresentam comportamento independente do tempo e diretamente proporcional entre tensão e taxa de cisalhamento, não sendo influenciados pelo grau de deformação. Assim, a linha de fluxo para esses líquidos é uma reta e a viscosidade é influenciada por alterações nas taxas de cisalhamento (Figura 11) 
(CASTRO, 2007; SCHRAMM, 2006). No entanto, em suspensões a viscosidade depende da taxa de cisalhamento, pois apresentam partículas insolúveis que podem ou não se posicionar segundo as linhas de fluxo, afetando a fluidez. Logo, não há proporção entre tensão e taxa de cisalhamento, como nos fluidos newtonianos, sendo denominados fluidos não-newtonianos (LYRA, 2010).

Os fluidos não-newtonianos são classificados conforme o seu comportamento em relação ao tempo, sendo: 1) dilatantes ou pseudoplásticos, independentes do tempo, 2) tixotrópicos ou reopéxicos que dependem do tempo. A Figura 11 contém o gráfico dos comportamentos reológicos independentes do tempo, em função da tensão de cisalhamento versus taxa de cisalhamento aplicada.

Figura 11 - Comportamentos reológicos independentes do tempo.
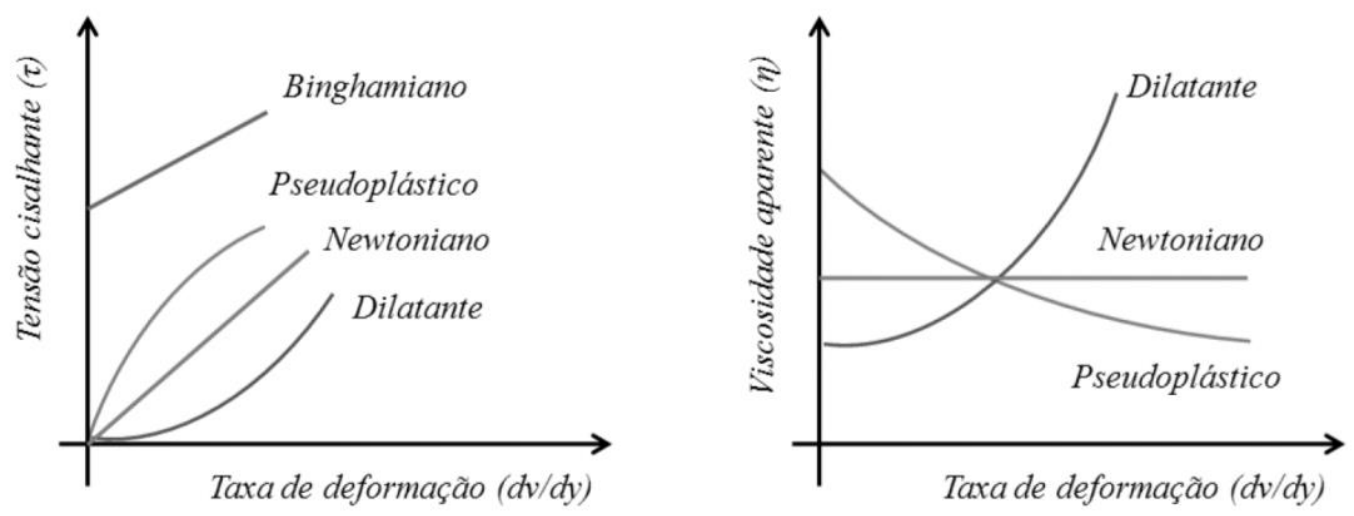

Fonte: Adaptado de Fox e McDonald (1998).

\subsubsection{Comportamento Pseudoplástico}

O comportamento pseudoplástico das suspensões é caracterizado pelo aumento da viscosidade sob baixas taxas de cisalhamento e diminuição com a elevação da velocidade de cisalhamento. Essas alterações de fluidez ocorrem, porque em baixos índices de cisalhamento, as partículas não sofrem orientação, diminuindo a fluidez e dificultando a aplicação do material. Já altas taxas de cisalhamento, induzem a orientação das partículas, o que diminui a viscosidade da suspensão e garante a trabalhabilidade ideal (SCHRAMM, 2006).

Segundo Oliveira et al. (2000), o comportamento pseudoplástico é natural de fluidos que apresentam menor viscosidade, quando submetidos a elevadas taxas de cisalhamento e sofre influência dos seguintes fatores: 
1) Interação entre as partículas - em baixas taxas de cisalhamento as suspensões apresentam alta viscosidade, devido ao movimento aleatório das partículas menores e maior influência das cargas de superfície.

2) Características físicas das partículas - as partículas assimétricas ou irregulares podem colidir em ângulos aleatórios, prejudicando a mobilidade e aumentando a viscosidade da suspensão.

\subsubsection{Comportamento Dilatante}

O comportamento dilatante ocorre em suspensões com alta concentração de partículas, logo em repouso ou sob baixas taxas de cisalhamento, as partículas se mantém dispersas, não havendo floculação. Já em altas taxas, há um aumento de colisões entre as partículas, aumentando o volume da suspensão e a viscosidade (SCHRAMM, 2006). Logo, mesmo com o aumento no teor de aditivo, não há diminuição da viscosidade da mistura.

Segundo Oliveira et al. (2000), o comportamento dilatante é natural de fluidos que apresentam maior viscosidade, quando submetidos a elevadas taxas de cisalhamento, portanto a dilatação da suspensão é influenciada por fatores que diminuem as distâncias entre as partículas e prejudicam a movimentação do sistema, sendo eles:

1) Características físicas das partículas - a assimetria e a rugosidade acentuam o atrito durante a movimentação, aumentando as forças repulsivas, o que provoca a dilatação volumétrica da suspensão.

2) Distribuição granulométrica estreita - pouca distância de separação entre as partículas.

3) Alta concentração volumétrica de sólidos - ocasionada por aglomerados difíceis de serem destruídos por cisalhamento e retém uma quantia de água. Camadas densas de dispersantes adsorvidas pelas superfícies das partículas também tendem a reter água em seu interior, provocando uma maior concentração volumétrica de sólidos e, consequentemente, o aumento da viscosidade.

\subsubsection{Fluidos de Bingham}

Alguns materiais não escoam se a tensão de cisalhamento aplicada for inferior ao limite de escoamento. Esses fluidos apresentam ligações interpartículas durante o repouso, que restringem os movimentos dos elementos e o escoamento é induzido quando as forças externas 
aplicadas superam as forças de ligação das estruturas internas. Quando a tensão de escoamento é excedida, a taxa de cisalhamento se torna proporcional à tensão de cisalhamento, como nos fluidos newtonianos. Materiais com esse comportamento são denominados fluidos binghamianos (CASTRO, 2007).

\subsubsection{Tixotropia e Reopexia}

Em suspensões tixotrópicas a viscosidade diminui em função do tempo com a aplicação de uma taxa de cisalhamento constante. Esse comportamento é originado em suspensões com aglomerados fracos, que demoram para se formar ou para serem destruídos. Assim, a orientação das partículas no fluxo varia em função do tempo, e o comportamento reológico é influenciado pela taxa e duração da solicitação aplicada (OLIVEIRA et al., 2000). Um fluido tixotrópico tem a propriedade de reversibilidade e retorna à sua forma original se mantido em repouso por um período (SCHRAMM, 2006).

A tixotropia pode ser observada em materiais cimentícios, pois os processos de dispersão e floculação permanecem em certo intervalo de tempo (estima-se 30 min após o contato do cimento com a água) até que comecem as reações de hidratação do cimento, que modificam as propriedades reológicas da suspensão de modo irreversível. Assim, é possível notar um comportamento tixotrópico apenas em curtos períodos de tempo, enquanto as influências irreversíveis dos produtos das reações de hidratação ainda podem ser desprezadas (ROUSSEL, 2006).

Por sua vez, os líquidos reopéxicos, ou anti-tixotrópicos, têm sua viscosidade aumentada em função do tempo, quando submetidos a uma taxa de cisalhamento constante e em repouso, podem recuperar o baixo nível de viscosidade original (SCHRAMM, 2006). Esse comportamento é observado em suspensões que apresentam aumento da dissolução de partículas em função do tempo, elevando a concentração de íons, que amenizam as forças de repulsão e favorecem a formação de aglomerados (OLIVEIRA et al., 2000).

A figura 12 ilustra as diferenças entre os comportamentos reopéxicos e tixotrópicos das suspensões, dependentes do tempo. 
Figura 12 - Comportamentos reológicos dependentes do tempo
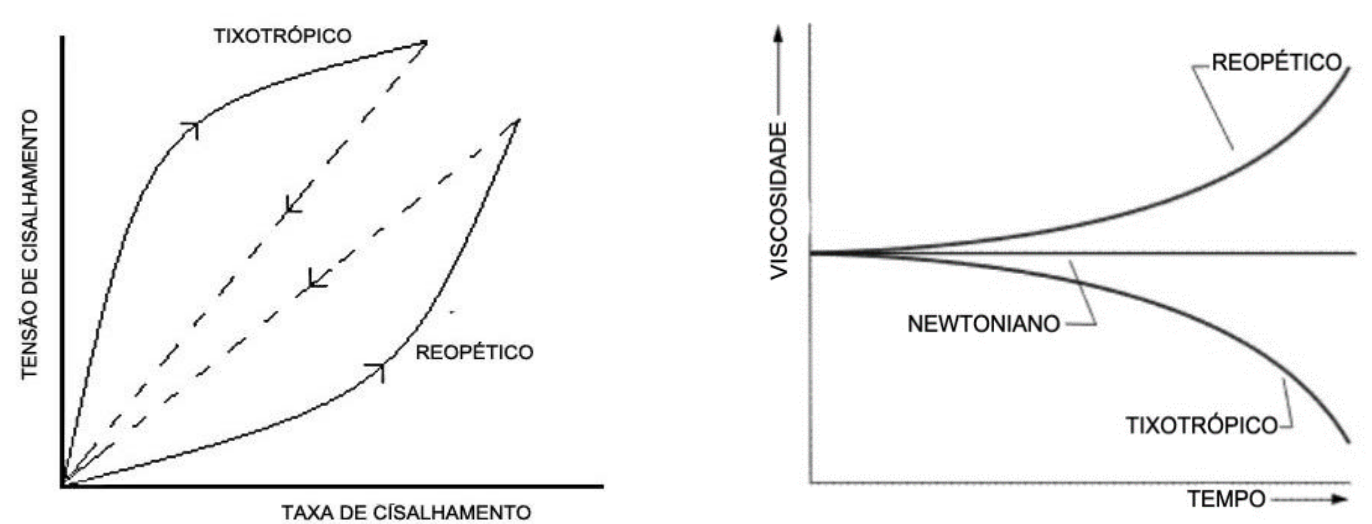

Fonte: Adaptado de Richardson (2011)

\subsubsection{Ensaios de laboratório $x$ reologia}

O comportamento reológico da matriz cimentícia depende da concentração volumétrica de sólidos, do teor de água adicionado à mistura e das cargas superficiais das partículas. Além disso, as suspensões podem apresentar comportamentos reológicos variáveis de acordo com as condições experimentais, como a intensidade e o tempo de mistura, quantidade de repetições e duração dos ciclos de cisalhamento. Logo é necessário padronizar os ensaios para determinação dos parâmetros reológicos, visando evitar resultados contraditórios (CASTRO; LIBORIO; PANDOLFELLI, 2011).

Muitas manifestações macroscópicas da reologia, observadas em suspensões com presença de aglomerados, como a tensão de escoamento e a viscosidade, estão diretamente relacionadas a fenômenos provocados pelas interações entre as partículas em nível microscópico (OLIVEIRA et al., 2000). Portanto, a relevância de se medir tanto a tensão de escoamento, quanto a viscosidade pode ser observada ao comparar duas misturas diferentes, que podem ter uma tensão de escoamento semelhante, enquanto a viscosidade pode ser completamente distinta (FERRARIS, 1999). A determinação de ambos os parâmetros reológicos permite diferenciar concretos que seriam considerados idênticos ao serem avaliados pelos métodos de ensaio padrões (CASTRO; LIBORIO; PANDOLFELLI, 2011).

Os concretos de alto desempenho são caracterizados pela acelerada perda de trabalhabilidade, que pode ser notada pelo aumento da tensão de escoamento, enquanto que a viscosidade pode se manter inalterada (CHEN et al., 1999). É necessário que a matriz apresente baixa tensão de escoamento e maior viscosidade, pois em baixas tensões o material estará apto 
a escoar sob seu peso próprio e a viscosidade mais alta evita a segregação dos elementos (CASTRO; LIBORIO; PANDOLFELLI, 2011). Logo, determinar o teor de saturação do dispersante é essencial para solucionar problemas de trabalhabilidade relacionados à dosagem excessiva de aditivo e o consequente aumento do custo de produção.

Os equipamentos mais utilizados para medição dos comportamentos reológicos da matriz dos concretos são o minicone e o Funil de Marsh, devido ao seu baixo preço, fácil manuseio e facilidade de transporte para utilização em obras. Porém, não existem normas técnicas que padronizem os métodos de determinação do teor ótimo de dispersante, utilizando essas ferramentas. Além disso, podem gerar resultados divergentes em misturas muito viscosas ou muito fluidas (MONTE; FIGUEIREDO, 2008). Assim, para verificar o comportamento de modo mais preciso, podem ser utilizados equipamentos experimentais como o reômetro e o viscosímetro. Porém, essas ferramentas de análise são mais apropriadas para utilização em escala laboratorial, devido ao alto preço e dificuldades de manipulação (CHOI et al., 2016).

\subsubsection{Funil de Marsh}

O Funil de Marsh visa determinar o comportamento reológico das suspensões sob altas taxas de cisalhamento, avaliando a viscosidade das pastas e serve como instrumento auxiliar para a determinação do ponto de saturação de dispersantes. Dentre as principais vantagens do uso dessa ferramenta de ensaio estão a facilidade de manipulação e transporte, a necessidade de poucas quantidades de material, o custo acessível e a simplicidade de análise (CASTRO, 2007; MONTE; FIGUEIREDO, 2008). A viscosidade é avaliada indiretamente pelo tempo de escoamento da suspensão pelo Funil de Marsh, assim a determinação da estabilização do tempo de escoamento indica o teor ótimo de dispersante para a viscosidade medida.

O ensaio consiste no preenchimento do cone com cavidade invertida, enquanto a pequena abertura localizada na parte inferior é fechada. Após colocado certo volume de pasta dentro do cone, o orifício inferior é desobstruído e o tempo para que um determinado volume de material escoe é cronometrado (CASTRO, 2007). A Figura 13 contém a explicação esquemática do ensaio de Funil de Marsh e a Figura 14 mostra o equipamento utilizado. 
Figura 13 - Esquema de execução do ensaio de Funil de Marsh

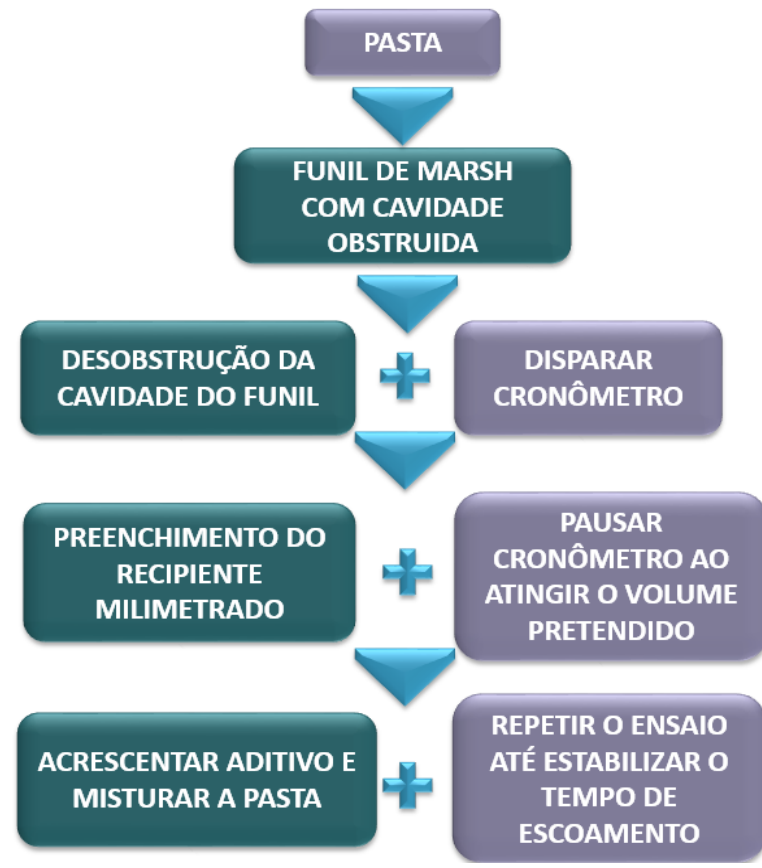

Fonte: Autora

Figura 14 - Funil de Marsh usado para medida indireta da viscosidade

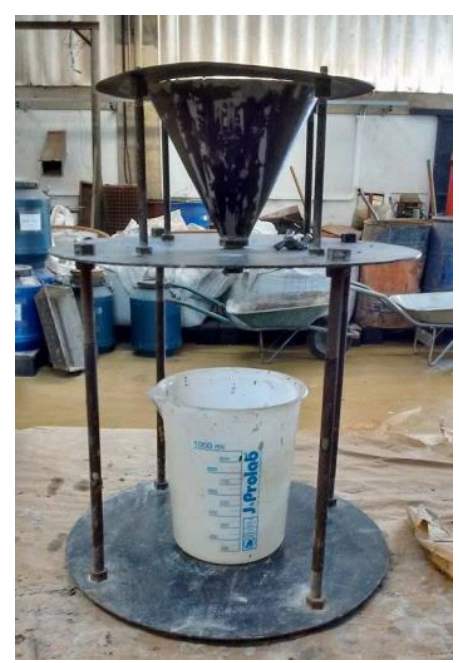

Fonte: Autora

O tempo de escoamento está relacionado ao comportamento do material referente à viscosidade e à tensão de escoamento, assim quanto maior o tempo cronometrado, maior a viscosidade da suspensão. Entretanto, o Funil de Marsh pode ser inútil para fluidos que apresentem alta tensão de escoamento, pois o gradiente de pressão gerado pelo peso próprio da suspensão sobre a abertura do funil pode não ser o bastante para fazer a tensão de cisalhamento superar a tensão de escoamento do material (ROUSSEL; LE ROY, 2005). A Figura 15 mostra 
a curva típica de resultados dos ensaios de determinação do ponto de saturação do dispersante, o ponto em destaque indica o teor ideal para a mistura.

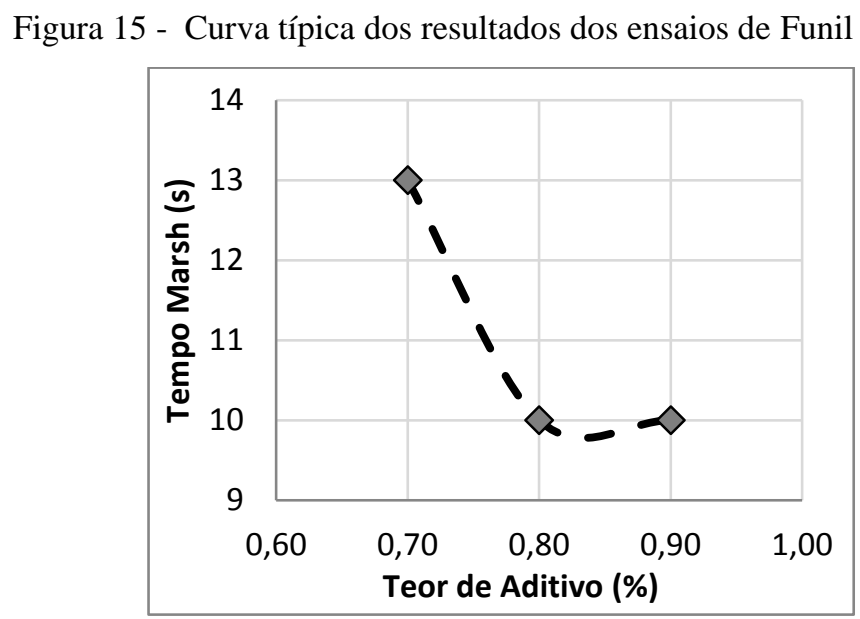

Fonte: Autora

Benaicha et al. (2015) estudaram os efeitos da dosagem de dispersante em variadas suspensões feitas com diferentes fíleres, medindo o tempo de escoamento e o espalhamento das pastas, através de uma nova ferramenta: o Funil de Marsh acoplado a uma canaleta de vidro. Os resultados obtidos foram comparados aos dados fornecidos pelas análises feitas no reômetro e confirmaram a viabilidade do uso desse método para caracterizar a fluidez das pastas. O tempo de escoamento caracterizou a tensão de escoamento e a viscosidade dos fluidos, enquanto o espalhamento na canaleta permitiu a visualização dos níveis de segregação das misturas. As Figuras 16 e 17 mostram a técnica utilizada pelos pesquisadores e a fluidez das pastas de acordo com o aumento do teor de dispersante, respectivamente.

Figura 16 - Funil de Marsh acoplado na canaleta de vidro

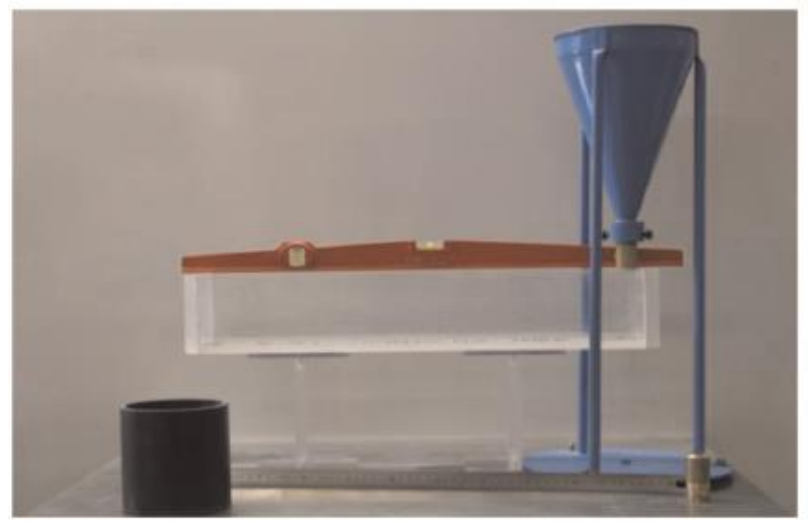

Fonte: Benaicha et al. (2015) 
Figura 17 - Espalhamento das suspensões de acordo com o teor de dispersante
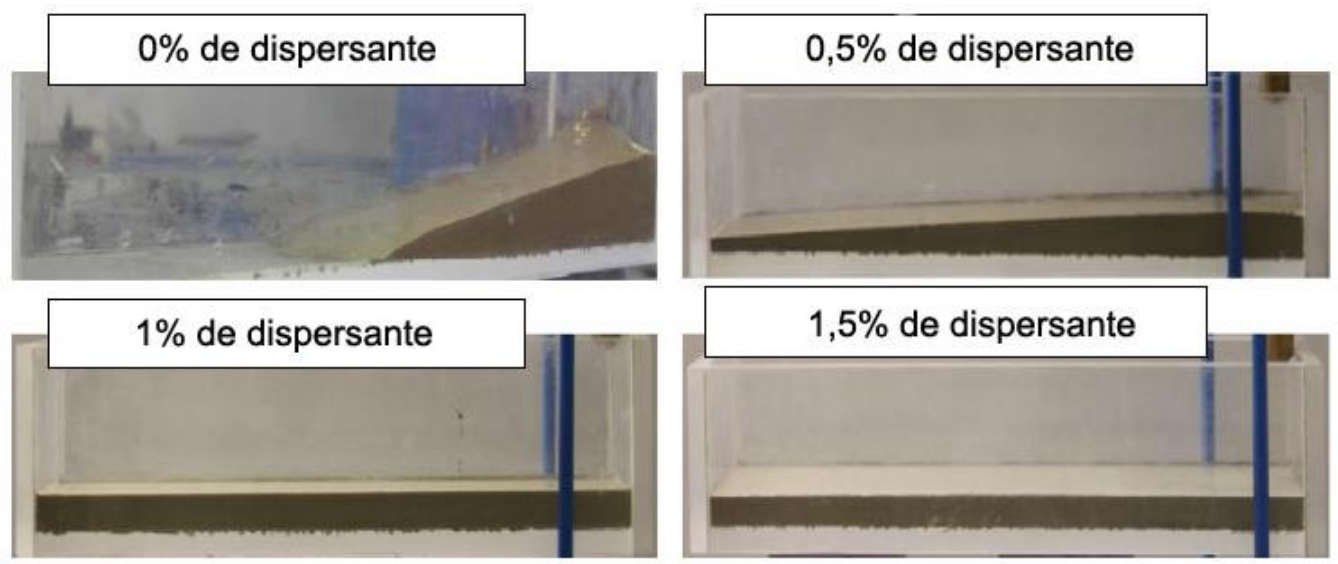

Fonte: Benaicha et al. (2015)

\subsubsection{Minicone: espalhamento e tempo de espalhamento}

As principais vantagens do uso minicone para avaliação dos parâmetros reológicos dos materiais, são o pequeno volume de amostra de material necessário para análise, o fácil manuseio, a viabilidade de utilização para análise em campo e possibilitar a observação do grau de segregação das misturas. Além disso, permite observar e comparar a fluidez de diversas misturas de cimento/dispersante, auxiliando na determinação da tensão de escoamento através da fluidez pela força peso (MONTE; FIGUEIREDO, 2008).

O ensaio de espalhamento consiste no preenchimento do minicone com uma pequena quantidade de pasta, apoiado sobre uma placa de vidro com marcação dos 2 diâmetros perpendiculares. Ao levantar o minicone verticalmente, é necessário cronometrar o tempo que a suspensão leva para atingir a marcação de $120 \mathrm{~mm}$ e verificar o espalhamento máximo atingido após a estabilização. Esse ensaio é utilizado para avaliar a tensão de escoamento do material e o potencial de segregação da suspensão, possibilitando a observação da influência do dispersante e outras adições na mistura. A habilidade de espalhamento da pasta é verificada pelo tempo em que a mistura leva para atingir o diâmetro de 120mm (CASTRO, 2007). A Figura 18 contém a explicação esquemática do ensaio de espalhamento pelo minicone e a Figura 19 mostra a ferramenta utilizada. 
Figura 18 - Esquema de execução do ensaio de espalhamento pelo minicone

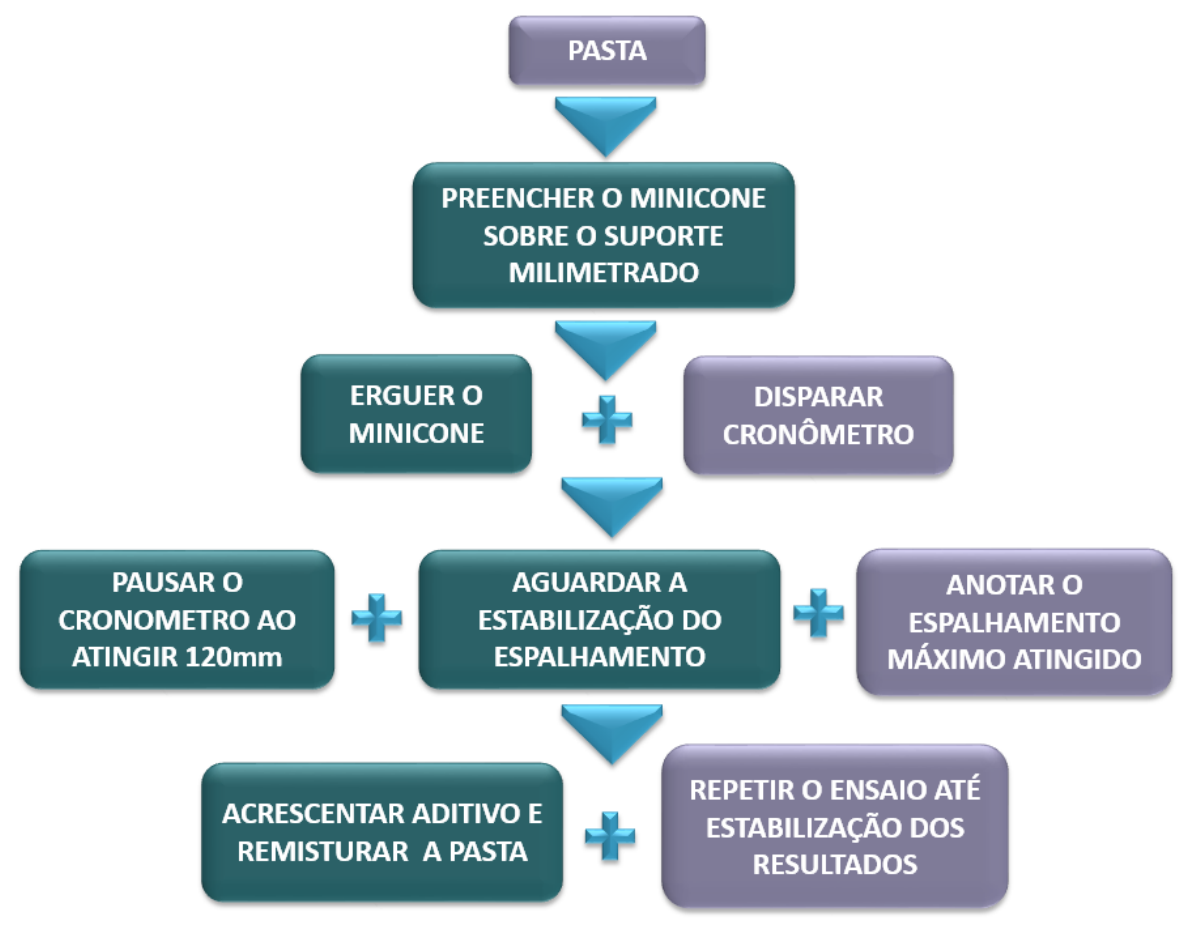

Fonte: Autora

Figura 19 - Minicone utilizado para medida indireta da tensão de escoamento.

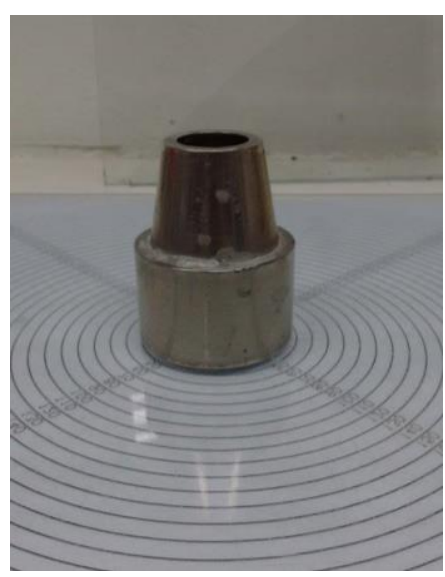

Fonte: Autora

Quando o cone preenchido com a pasta é levantado, a gravidade induz o espalhamento do material sobre o seu peso próprio, que ocorre devido à superação da sua tensão de escoamento (BOUVET; GHORBEL; BENNACER, 2010). De acordo com Roussel, Stefani e Leroy (2005), se o esforço de cisalhamento na suspensão testada supera a tensão de escoamento, o espalhamento é interrompido. A Figura 20 mostra o gráfico de um resultado típico do ensaio de espalhamento pelo minicone. 
Figura 20 - Curva típica dos resultados dos ensaios de espalhamento pelo minicone

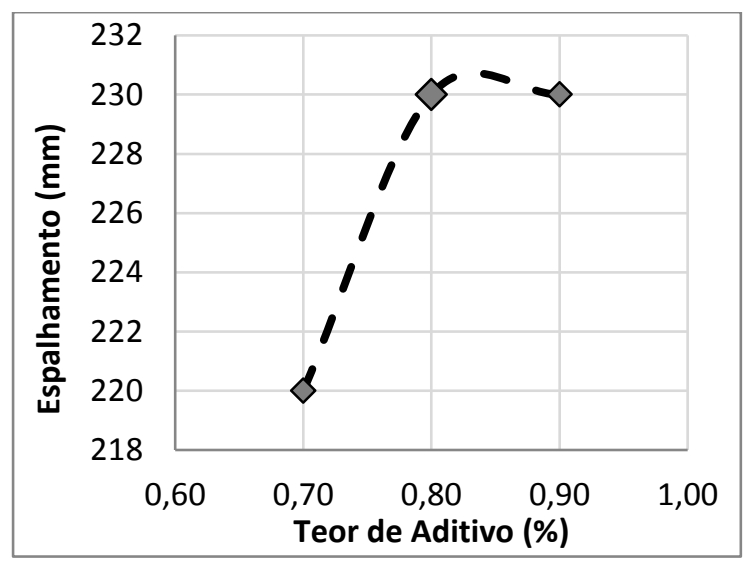

Fonte: Autora

Choi et al. (2016) verificaram o comportamento reológico de quatro tipos de pastas de concreto de alto desempenho, comparando os resultados de tensão de escoamento e viscosidade obtidos por meio dos ensaios de mini slump com dados de análise gerados pelo reômetro. Os experimentos revelaram correlações existentes entre o diâmetro final de espalhamento e a tensão de escoamento, e o tempo de espalhamento e a viscosidade/tensão de escoamento. De acordo com os autores, se a tensão de escoamento for 0 , o espalhamento não atinge o valor de diâmetro mínimo proposto $(120 \mathrm{~mm})$, devido ao aumento da viscosidade. Quando existe uma tensão de escoamento, o diâmetro de espalhamento aumenta com o tempo, indicando a fluidez do material. A Figura 21 ilustra os ensaios de espalhamento feitos por Choi et al. (2016).

Figura 21 - variação do diâmetro de espalhamento com o tempo

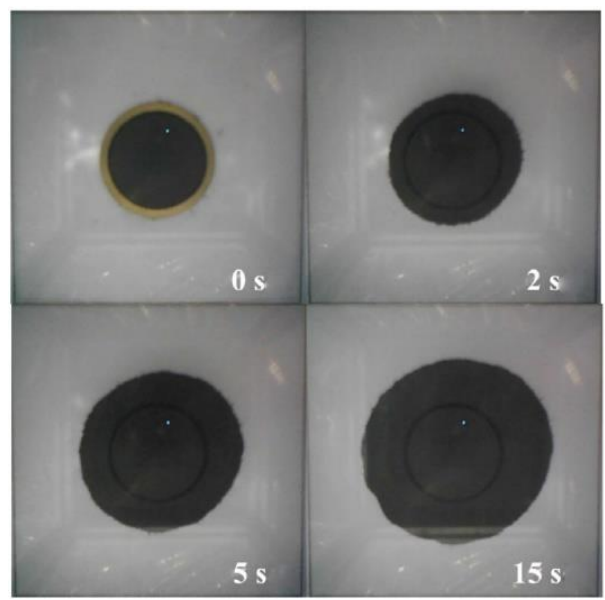

Fonte: Choi et al. (2016) 


\section{FORMULAÇÃO DE PASTAS E ARGAMASSAS EFICIENTES}

O planejamento experimental proposto no presente trabalho teve como objetivo verificar a influência das características dos fíleres de quartzo no comportamento reológico e mecânico da matriz, visando a substituição de parte do cimento na produção de materiais cimentícios. Para formular uma matriz eficiente, de modo a reduzir o teor de água e de clínquer incorporados através da adição de fíleres, é necessário avaliar os seguintes parâmetros: 1) características físicas das matérias-primas, como a distribuição da granulometria, o formato e a área superficial; 2) o comportamento reológico da suspensão, analisando a influência dos fíleres sobre a viscosidade e a tensão de escoamento; 3) a proporção adequada dos componentes da mistura; 4) determinar os teores ótimos de dispersante, garantindo a máxima trabalhabilidade com o mínimo de água.

\subsection{PLANEJAMENTO EXPERIMENTAL, MATERIAIS E MÉTODOS}

O planejamento experimental elaborado foi baseado na variação da granulometria dos fíleres e nas consequentes variações de área superficial, já que se trata de um material de baixa variabilidade na composição química. As variáveis experimentais estudadas foram:

1) Granulometria - uso de fíleres de quartzo de distintas granulometrias, que foram doados pela mineradora Jundu presente na região de Analândia - SP;

2) Área superficial - os fíleres adquiridos apresentam diferentes áreas superficiais;

3) Teor de água - a água afasta os materiais na suspensão, mas é adsorvida na superfície das partículas finas. A variação da granulometria e área superficial dos fíleres de quartzo pode influenciar no consumo de água das pastas, fator fundamental para uma avaliação do potencial de uso destes materiais, visto que o aumento do teor de água aumenta a porosidade e diminui a resistência mecânica.

Algumas condições experimentais foram fixadas:

1) Cimento - foi usado um cimento CPV ARI da marca Lafarge, que é o mais puro encontrado no mercado (composto por clínquer e gipsita, e apenas uma pequena parcela de fíler calcário);

2) Adições minerais como escória de alto-forno ou pozolanas foram evitadas, para se isolar a avaliação da influência do fíler;

3) Padronização do procedimento de mistura com uso de altas taxas de cisalhamento para garantir boa dispersão das partículas e uniformização dos dados; 
4) Aditivo dispersante à base de policarboxilato da marca Glenium 51.;

5) Dimensão e adensamento dos corpos-de-prova para resistência à compressão, cilíndricos, 3 para cada idade (7 e 28 dias);

6) A temperatura e a umidade no processo de cura serão constantes, com uso de câmara úmida com $\mathrm{UR}=95 \%$ e temperatura $23^{\circ} \mathrm{C}$ até o momento da realização do ensaio de ruptura à compressão uniaxial.

7) O teor de dispersantes ideal nas pastas foi determinado a partir de sequências de ensaios de reologia no minicone e no Funil de Marsh.

8) Foram utilizados três fíleres de quartzo com granulometria mais fina, intermediária e mais grossa, substituindo $40 \%$ e $60 \%$ em volume de cimento nas dosagens estabelecidas.

9) Foi utilizada uma areia classificada como muito grossa, com módulo de finura 3,56.

A pesquisa foi dividida em três fases:

1) Caracterizações das matérias-primas, ensaios de reologia com foco nos parâmetros de viscosidade e tensão de escoamento, visando determinar o teor ótimo de dispersante para cada dosagem de pasta, e moldagem dos corpos de prova para os ensaios de resistência à compressão uniaxial;

2) Ensaios de repetitividade do comportamento reológico das misturas de pastas e avaliação da trabalhabilidade;

3) Estudo das argamassas feitas com as pastas produzidas nas etapas anteriores, assim foram realizados ensaios de consistência, variando o teor de água para o espalhamento fixo de $240 \mathrm{~mm}$ e teor de dispersante de $0,80 \%$ para todas as misturas, moldagem de amostras destinadas aos ensaios de resistência mecânica, e determinação do módulo de elasticidade.

As Figuras 22, 23 e 24 resumem esquematicamente as etapas 1, 2 e 3 do planejamento experimental. 
Figura 22 - Planejamento experimental da etapa 1 esquematizado

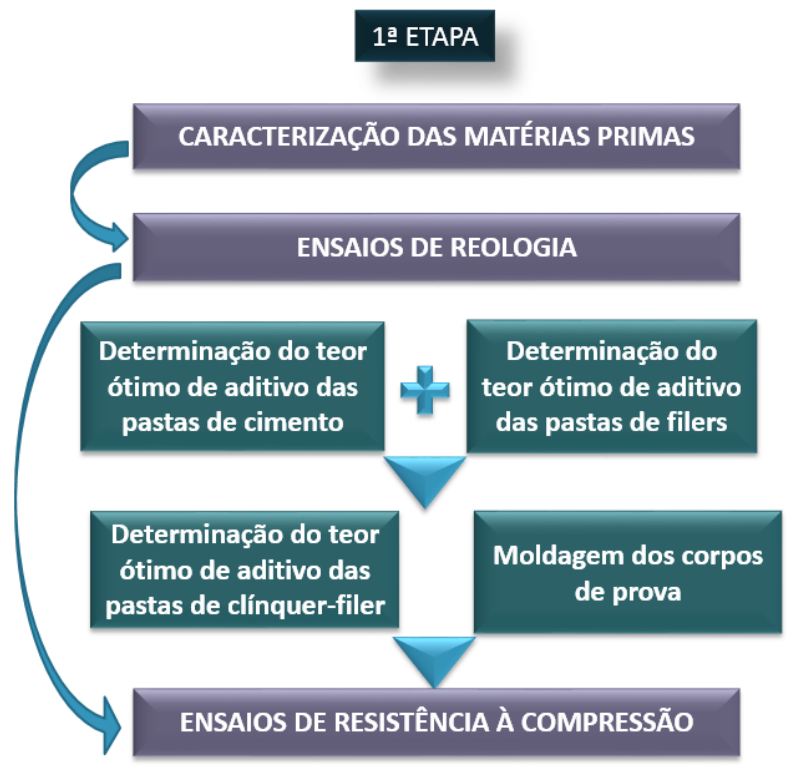

Figura 23 - Planejamento experimental da etapa 2 esquematizado

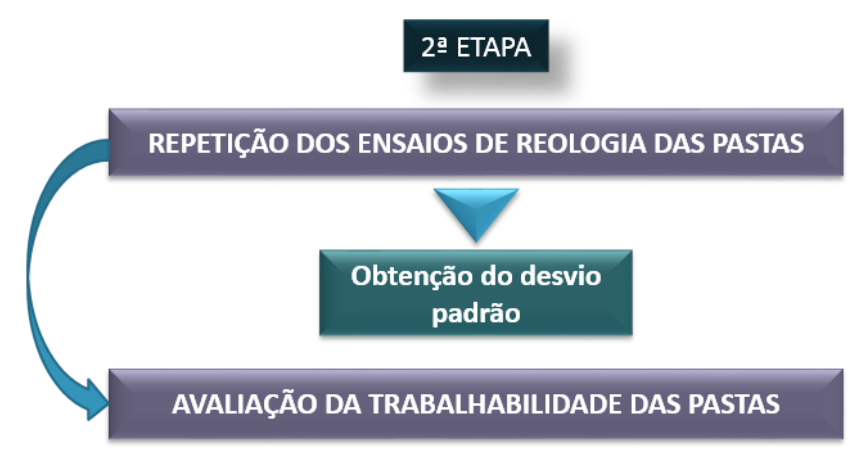

Figura 24 - Planejamento experimental da etapa 3 esquematizado

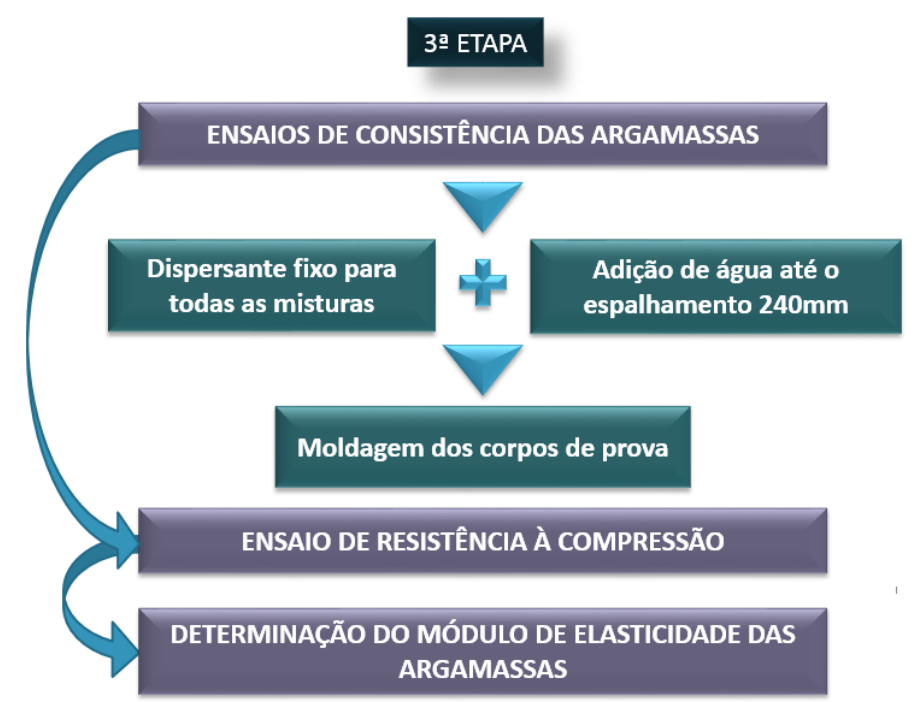




\subsubsection{Caracterização de matérias-primas}

\subsubsection{Composição granulométrica}

A composição granulométrica foi determinada através do equipamento DT-1202, Dispersion Technology, que utiliza um espectrômetro acústico e eletroacústico que determinam a distribuição granulométrica em suspensões concentradas.

\subsubsection{2 Área superficial}

A área superficial é um parâmetro importante não só para análise do comportamento reológico das partículas em suspensão, mas para cálculo do fator forma dos elementos. Para determinar a área superficial das partículas, foi utilizado o método de BET, referente às isotermas de adsorção estudadas por Brunauer, Emmett e Teller, utilizando o equipamento Quantachrome Autosorb 1200. Primeiramente é feito um pré-tratamento de secagem dos materiais em temperatura de $50^{\circ} \mathrm{C}$, durante 24 horas. Posteriormente é feita a degasagem do material, que é colocado em um recipiente fechado à vácuo, imerso em nitrogênio líquido de alta pureza, sob temperatura constante de cerca de $-196^{\circ} \mathrm{C}$ e pressões de até $2 \mathrm{~atm}$. Uma massa de gás nitrogênio é injetada no recipiente com o material e o sistema é mantido durante 2 horas. De acordo com os dados obtidos, o equipamento calcula o número de moléculas de gás adsorvidos na superfície das partículas e a área superficial.

\subsubsection{Densidade real}

A densidade real foi medida por meio da técnica de picnometria de He no equipamento Multipycnometer - Quantachrome Instuments, que permite determinar o volume da parte sólida, através da variação de pressão de gás numa câmara com volume conhecido. A análise da matéria-prima é feita após ser seca em estufa por 24 horas, sendo colocada uma massa conhecida na câmara do equipamento destinada às amostras. O gás He é injetado na câmara de referência, com volume conhecido, onde é medida a pressão atingida (P1). Posteriormente, o gás é transferido para a câmara da amostra, onde é registrada a pressão (P2). Logo, o volume do sólido é calculado pela seguinte equação:

$$
(V a-V s)=P 2 x(V a-V s+V e)
$$

Onde:

$V a=$ volume da câmara da amostra

$V e=$ volume da câmara de referência 
$V s=$ volume do sólido

Através do valor do volume do sólido, é possível calcular a densidade da matéria-prima, que é importante para o cálculo do traço em massa e em volume para as dosagens das misturas.

\subsubsection{Procedimentos de mistura das pastas}

Os procedimentos de mistura foram padronizados e seguiram as seguintes etapas:

1) Primeiramente foi adicionada a água e o teor de aditivo inicial (bem abaixo do teor ótimo) na argamassadeira, para posterior adição dos materiais secos, visando uma melhor homogeneização da mistura e evitar a formação de aglomerados na pasta. As matérias-primas foram adicionadas durante $2 \mathrm{~min}$, sob velocidade baixa de cisalhamento. Posteriormente, no mesmo equipamento, a mistura foi submetida a uma velocidade mais alta de cisalhamento durante 3 min para aumentar a taxa de dispersão dos grãos. Entretanto, esse equipamento não é suficiente para uniformizar a mistura, portanto, para maior dispersão das partículas do fluido, foi utilizada uma segunda ferramenta que proporciona maiores taxas de cisalhamento.

A Figura 25 mostra o equipamento utilizado na primeira etapa do procedimento de mistura.

Figura 25 - Argamassadeira utilizada para homogeneização das matérias-primas

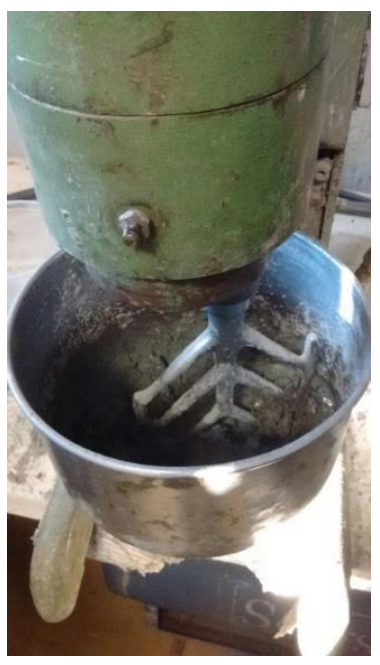

Fonte: Autora

2) Na segunda etapa, para possibilitar a mistura de pequenos volumes de pastas concentradas e em altas taxas de cisalhamento, foi utilizada a furadeira Bosch, 750W, fixada em uma base. Para execução das misturas, foi utilizado um 
misturador de argamassas comercial (Figura 26), acoplado na furadeira. Assim, a pasta foi transferida para um recipiente de vidro e misturada neste equipamento durante 2 min. Após os procedimentos de mistura, foram realizados os ensaios de avaliação do comportamento reológico das pastas.

Figura 26 - Misturador utilizado para altas velocidades de cisalhamento e dispersão

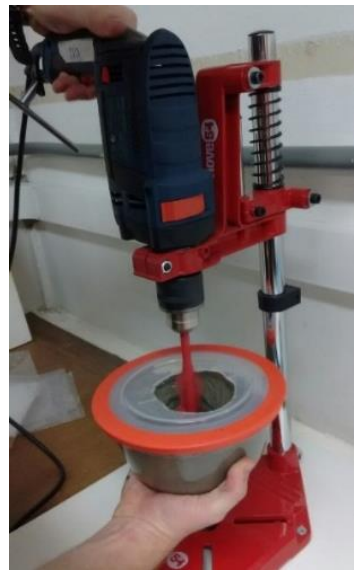

Fonte: Autora

\subsubsection{Composições das pastas}

Para dosagem das pastas, os teores de água para as misturas de cimento puro foram fixados nos fatores água/cimento 0,21-0,23-0,25, os teores de água para as misturas com o fíler foram estimados de acordo com a observação do comportamento do material em suspensão, sendo ensaiadas nos fatores água/sólidos 0,30-0,33. O volume total de dispersante foi calculado através da soma das massas de sólidos, multiplicada pela porcentagem de aditivo a ser aumentada, até atingir o teor ótimo por meio dos ensaios de reologia. As Tabelas 3 e 4, mostram as composições das pastas feitas com as matérias-primas puras, cimento e fíler de quartzo, respectivamente.

Tabela 3 - Composição das pastas de cimento com fator água/cimento

\begin{tabular}{c|c}
\hline \multicolumn{2}{c}{ Pastas 100\% CPV } \\
\hline FATOR A/C & DISPERSANTE \\
\hline 0,21 & $1,80 \%$ \\
0,23 & $1,40 \%$ \\
0,25 & $1,00 \%$ \\
\hline
\end{tabular}


Tabela 4 - Composição das pastas de fíleres com fator água/sólidos

\begin{tabular}{c|cc}
\hline \multicolumn{3}{c}{ PASTAS DE FÍLER DE QUARTZO } \\
\hline TIPO DE FÍLER & FATOR A/S & DISPERSANTE \\
\hline \multirow{2}{*}{ SM 200 } & 0,30 & $0,10 \%$ \\
& 0,33 & $0,10 \%$ \\
\hline \multirow{2}{*}{ SM 325 } & 0,30 & $0,80 \%$ \\
& 0,33 & $0,40 \%$ \\
\hline \multirow{2}{*}{ SM 400 } & 0,30 & $1,40 \%$ \\
& 0,33 & $0,20 \%$ \\
\hline
\end{tabular}

As pastas de cimento-fíler foram produzidas nas relações água/sólidos de 0,21-0,230,25 , a fim de possibilitar comparações com o comportamento das matrizes de CPV puro com mesmo teor de água. Para as misturas clínquer-fíler, foram feitas substituições em volume de cimento por finos de quartzo nas porcentagens de $40 \%$ e $60 \%$. Além disso, para realização dos ensaios, foram feitos $750 \mathrm{ml}$ de pasta e foi utilizado o dispersante Glenium 51 à base de policarboxilato. A Tabela 5 mostra as composições das pastas de cimento-fíler para cada tipo de fíler.

Tabela 5 - Composição em volume das pastas de cimento-fíler

\begin{tabular}{|c|c|c|c|c|c|c|c|}
\hline \multicolumn{2}{|c|}{ Fíler } & $\mathrm{a} / \mathrm{c}$ & $\mathrm{a} / \mathrm{s}$ & $\mathrm{C}\left(\mathrm{kg} / \mathrm{m}^{3}\right)$ & Fíler $\left(\mathrm{kg} / \mathrm{m}^{3}\right)$ & Água $\left(\mathrm{kg} / \mathrm{m}^{3}\right)$ & Aditivo (\%) \\
\hline SM 200 & & & \multirow{7}{*}{0,21} & & & & 0,80 \\
\hline SM 325 & $40 \%$ & 0,33 & & 864,74 & 492,81 & 285,09 & 1,10 \\
\hline SM 400 & & & & & & & 1,40 \\
\hline CPV & $100 \%$ & 0,21 & & 1408,24 & 0,00 & 295,73 & 1,80 \\
\hline SM 200 & \multirow{3}{*}{$60 \%$} & \multirow{3}{*}{0,48} & & \multirow{3}{*}{583,33} & \multirow{3}{*}{747,98} & \multirow{3}{*}{297,57} & 0,80 \\
\hline SM 325 & & & & & & & 1,10 \\
\hline SM 400 & & & & & & & 1,20 \\
\hline SM 200 & \multirow{3}{*}{$40 \%$} & \multirow{3}{*}{0,36} & \multirow{7}{*}{0,23} & \multirow{3}{*}{834,53} & \multirow{3}{*}{475,59} & \multirow{3}{*}{301,33} & 0,70 \\
\hline SM 325 & & & & & & & 0,80 \\
\hline SM 400 & & & & & & & 1,10 \\
\hline $\mathrm{CPV}$ & $100 \%$ & 0,23 & & 1266,78 & 0 & 291,36 & 1,40 \\
\hline SM 200 & \multirow{3}{*}{$60 \%$} & \multirow{3}{*}{0,52} & & \multirow{3}{*}{563,33} & \multirow{3}{*}{722,33} & \multirow{3}{*}{295,7} & 0,60 \\
\hline SM 325 & & & & & & & 0,90 \\
\hline SM 400 & & & & & & & 0,90 \\
\hline SM 200 & \multirow{3}{*}{$40 \%$} & \multirow{3}{*}{0,39} & \multirow{7}{*}{0,25} & \multirow{3}{*}{806,36} & \multirow{3}{*}{459,54} & \multirow{3}{*}{316,47} & 0,60 \\
\hline SM 325 & & & & & & & 0,80 \\
\hline SM 400 & & & & & & & 1,00 \\
\hline CPV & $100 \%$ & 0,25 & & 1309,86 & 0,00 & 327,46 & 1,00 \\
\hline SM 200 & & & & \multirow{3}{*}{544,66} & \multirow{3}{*}{698,39} & \multirow{3}{*}{310,76} & 0,60 \\
\hline SM 325 & $60 \%$ & 0,57 & & & & & 0,70 \\
\hline SM 400 & & & & & & & 0,80 \\
\hline
\end{tabular}




\subsubsection{Procedimentos de mistura das argamassas}

As argamassas foram misturadas na argamassadeira, com teor de dispersante fixo de 0,80\% em volume, enquanto a água foi adicionada até que a mistura atingisse o espalhamento pré-determinado de $240 \mathrm{~mm}$, devido à facilidade de aplicação e moldagem de materiais cimentícios que necessitam de alta fluidez. A alta fluidez envolve maiores dificuldades para se atingir a eficiência do uso dos ligantes na produção de materiais, devido à necessidade de alto teor de água, portanto os experimentos foram feitos sobre misturas na pior situação. A dosagem de dispersante foi fixada a partir de ensaios de determinação do mínimo teor necessário para máxima fluidez, possibilitando as análises da influência granulométrica dos fíleres sobre a quantidade de água exigida nas misturas. Assim, foram realizados os seguintes procedimentos:

1) Adição do cimento e do fíler de quartzo com uma pequena quantidade de água inicial, misturado durante 30 s em alta rotação;

2) Adição de uma areia com granulometria de classificação muito grossa, misturada durante 30 s em baixa rotação;

3) Retirada da mistura da argamassadeira para ensaio de consistência e medida do espalhamento;

4) Enquanto o espalhamento não era atingido, a argamassa foi remisturada, aumentando o teor de água. A cada $10 \mathrm{~g}$ de água adicionado, o material foi misturado por 30s em baixa rotação.

O ensaio de consistência das argamassas é regulamentado pela NBR 7215/1996. O equipamento consiste em uma mesa metálica plana, fixa sobre uma haste que se movimenta verticalmente de $(12,5 \pm 0,2) \mathrm{mm}$ através de uma manivela (Figura 27), gerando um impacto que provoca o espalhamento após levantamento do molde cônico.

\section{Figura 27 - Equipamento utilizado para ensaio de consistência}

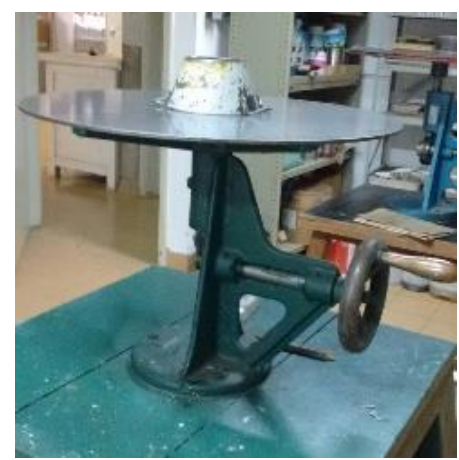

Fonte: Autora 
Antes da realização do ensaio, a mesa de apoio foi lubrificada com óleo mineral para evitar a adesão e a perda de material. O molde cônico metálico foi colocado no centro e preenchido por 3 camadas de argamassa, recebendo 15 golpes com soquete uniformes e bem distribuídos na primeira camada, 10 golpes na segunda e 5 golpes na terceira. Posteriormente, o cone foi retirado de forma vertical e girou-se a manivela 30 vezes, provocando o espalhamento da argamassa. A medida dos diâmetros foi feita com um paquímetro e o ensaio foi repetido até atingir a consistência próxima de $(240 \pm 5) \mathrm{mm}$. Após a conclusão do ensaio, foram moldados os corpos de prova destinados ao ensaio de resistência mecânica e módulo de elasticidade. A Figura 28 mostra as etapas da execução do ensaio.

Figura 28 - Etapas de execução do ensaio de consistência das argamassas

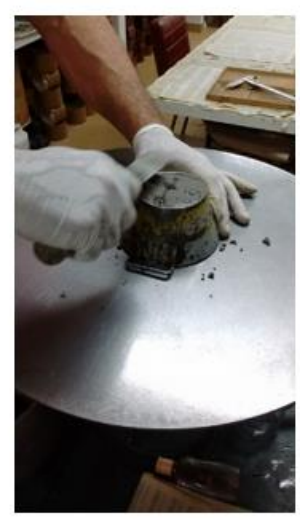

(a) Preenchimento e retificação do cone

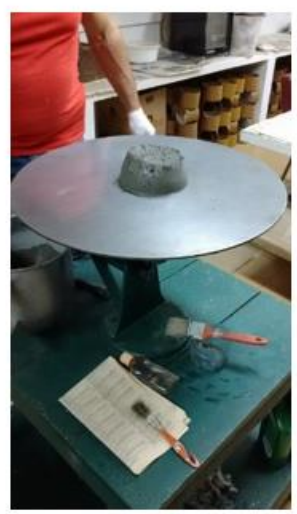

(c) Abatimento da argamassa antes de girar a manivela

Fonte: Autora

\subsubsection{Composições das argamassas}

As argamassas foram misturadas com composições de 100\% CPV, $40 \%$ e $60 \%$ de fíler de quartzo sobre o volume de cimento, e areia média. $\mathrm{O}$ teor de dispersante foi fixado para possibilitar a comparação entre as quantidades de água exigidas por cada dosagem para atingir 
a consistência de $240 \mathrm{~mm}$, e os valores de resistência mecânica dos corpos de prova. A Tabela 6 , mostra as dosagens utilizadas.

Tabela 6 - Dosagem das argamassas

\begin{tabular}{lccccccc}
\hline Dosagem & Água/cimento & Água/sólidos & $\mathrm{C}\left(\mathrm{kg} / \mathrm{m}^{3}\right)$ & $\begin{array}{c}\text { Fíler } \\
\left(\mathrm{kg} / \mathrm{m}^{3}\right)\end{array}$ & $\begin{array}{c}\text { Areia } \\
\left(\mathrm{kg} / \mathrm{m}^{3}\right)\end{array}$ & $\begin{array}{c}\text { Água } \\
\left(\mathrm{kg} / \mathrm{m}^{3}\right)\end{array}$ & Aditivo $(\%)$ \\
\hline $40 \%$ SM 200 & 0,48 & 0,27 & 414,27 & 273,71 & 1479,52 & 199,74 \\
$40 \%$ SM 325 & 0,48 & 0,27 & 414,27 & 273,71 & 1479,52 & 199,74 \\
$40 \%$ SM 400 & 0,44 & 0,25 & 420,49 & 277,82 & 1501,74 & 187,72 & $0,80 \%$ \\
\hline $100 \%$ CPV & 0,30 & 0,30 & 723,05 & 0 & 1446,1 & 216,91 & \\
\hline $60 \%$ SM 200 & 0,86 & 0,31 & 258,64 & 387,96 & 1436,88 & 222,72 \\
60\% SM 325 & 0,72 & 0,26 & 268,27 & 402,41 & 1490,42 & 193,75 \\
$60 \%$ SM 400 & 0,80 & 0,29 & 262,41 & 393,61 & 1457,82 & 211,38 \\
\hline
\end{tabular}

\subsubsection{Comportamento Reológico das Pastas}

As características reológicas das suspensões estudadas foram avaliadas por ensaio de espalhamento pelo minicone (tensão de escoamento) e Funil de Marsh (viscosidade). Através das análises do comportamento reológico, foram estabelecidos os teores ótimos de dispersante em diferentes teores de água e de substituição de fíler de quartzo por cimento ( $40 \%$ e $60 \%$ ). Os pontos de saturação de dispersante nas misturas foram determinados a partir da estabilização dos valores determinados pelos ensaios de Funil de Marsh e minicone, que indicam o estado em que há adsorção completa do aditivo em toda a área superficial das partículas. Assim, a análise da reologia das pastas seguiu as seguintes etapas:

a) as primeiras análises foram feitas para as pastas com as matérias-primas puras e teores de água variáveis, a fim de observar o comportamento dos materiais separadamente. As matérias-primas apresentam diferentes áreas superficiais, que podem adsorver quantidades variáveis de dispersante. Além disso, o teor de água influencia no afastamento das partículas, exigindo maiores ou menores dosagens de dispersante para manter o distanciamento entre os grãos.

b) a dosagem mínima inicial de dispersante para cada mistura de cimento-fíler foi estipulada a partir da média ponderada entre os teores ótimos determinados para as matériasprimas puras. Foram avaliados os comportamentos reológicos das misturas de cimento-fíler, com substituições de $40 \%$ e $60 \%$ de fíler de quartzo em diferentes teores de água, determinando os teores ótimos de aditivo para cada mistura.

c) com as dosagens ótimas de dispersante estabelecidas, foram feitos ensaios para avaliação da reologia das pastas para moldagem dos corpos de prova, destinados aos testes de resistência à compressão. 


\subsubsection{Descrição: ensaio de Funil de Marsh}

Os ensaios de Funil de Marsh foram feitos logo após as pastas serem misturadas sob altas taxas de cisalhamento durante $2 \mathrm{~min}$ na furadeira, de acordo com os seguintes procedimentos:

1) Uma quantidade de pasta foi adicionada no Funil de Marsh até o seu completo preenchimento, enquanto a cavidade inferior se mantinha fechada.

2) Após abertura da cavidade inferior do funil, mediu-se o tempo (t) que o fluido levou para preencher $400 \mathrm{ml}$ do recipiente graduado.

O tempo de escoamento é considerado como o parâmetro de medição indireta da viscosidade da pasta. Logo, para análise, considera-se que quanto menor o tempo de escoamento da mistura, menor é a viscosidade. Na Figura 29a, são mostrados exemplos de misturas com baixa viscosidade e na Figura 29b, uma mistura com alta viscosidade, onde o escoamento pelo Funil de Marsh é dificultado e demanda maior tempo.

Figura 29 - Ensaio para avaliação da viscosidade, utilizando o Funil de Marsh

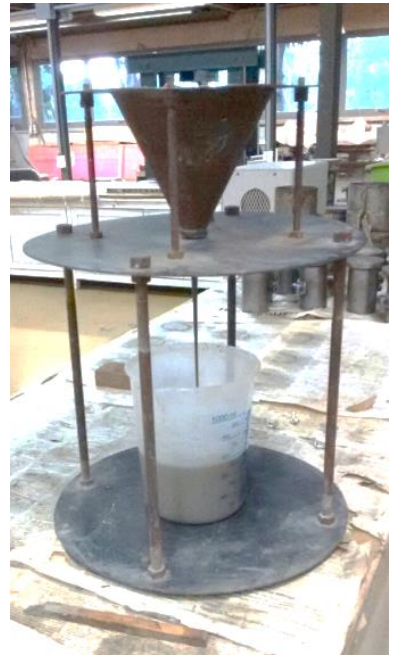

(a) Mistura com baixa viscosidade

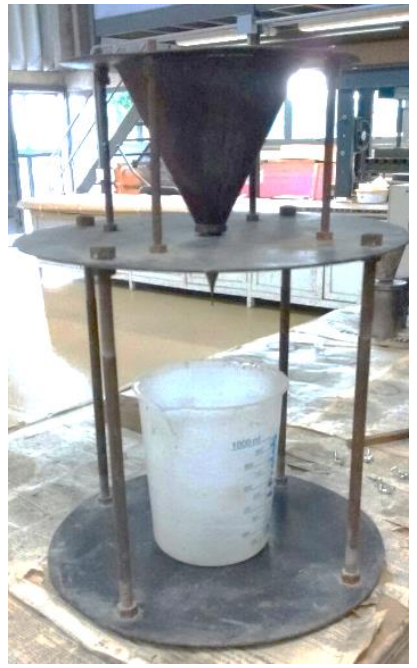

(b) Mistura com alta viscosidade

Fonte: Autora

\subsubsection{Descrição: ensaio de espalhamento pelo minicone}

Após o ensaio no Funil de Marsh, a pasta foi colocada no Minicone (Figura 30) até seu completo preenchimento. O ensaio foi de acordo com os seguintes procedimentos:

1) $\mathrm{O}$ minicone foi colocado sobre uma base milimetrada diametralmente e foi preenchido por pasta; 
2) Após levantar o minicone verticalmente, foi cronometrado o tempo para a mistura atingir $\mathrm{d}=120 \mathrm{~mm}$. Quanto menor o tempo, maior é a habilidade de espalhamento da pasta.

3) O diâmetro máximo atingido foi anotado, após estabilização do espalhamento.

A tensão de escoamento (Te) está diretamente ligada ao diâmetro máximo de espalhamento atingido pela pasta.

As Figuras 30a, 30b e 30c, ilustram exemplos dos diâmetros de espalhamento das pastas, sendo que a pasta $30 \mathrm{a}$ apresenta maior tensão de escoamento $\left(\sigma_{e}\right)$, a $30 \mathrm{~b} \operatorname{com} \sigma_{e}$ intermediária e a 30c com baixa $\sigma_{e}$.

Figura 30 - Aspecto das pastas durante o ensaio de espalhamento pelo Minicone

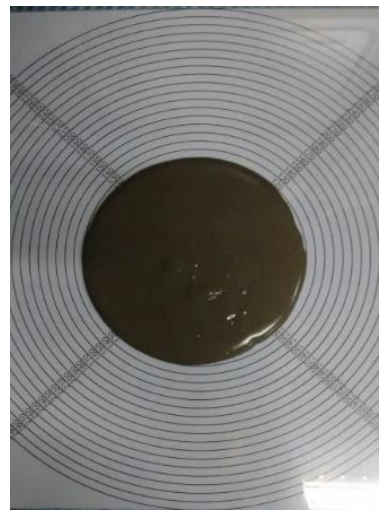

(a) $\sigma_{e}$ alta

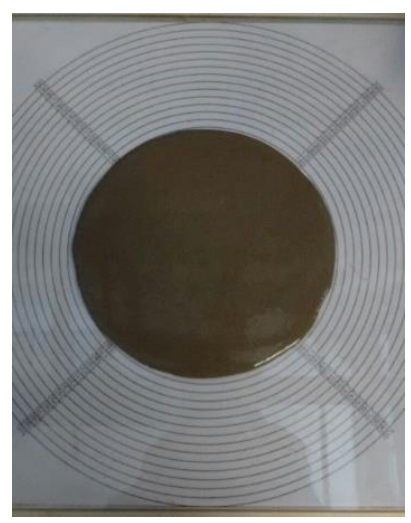

(b) $\sigma_{e}$ intermediária

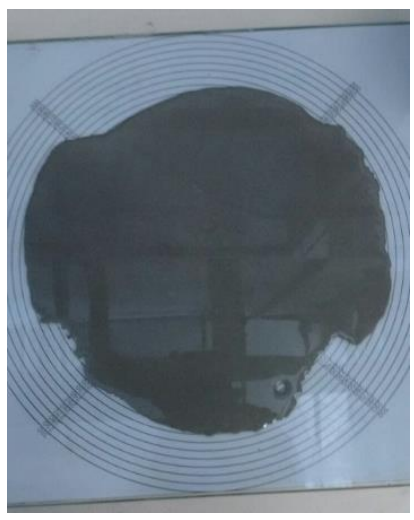

(c) $\sigma_{e}$ baixa

Fonte: Autora

\subsubsection{Determinação do teor ótimo de dispersante}

A determinação do teor ótimo de dispersante foi feita por meio dos ensaios de Funil de Marsh e espalhamento pelo minicone, e consistiu nos seguintes procedimentos:

1) Foi misturado um determinado teor de água e teor de aditivo mínimo inicial com o material, homogeneizados na argamassadeira durante $5 \mathrm{~min}$ e, posteriormente remisturados na furadeira Bosch por $2 \mathrm{~min}$.

2) Para as misturas de cimento-fíleres, o teor de dispersante inicial para realização dos ensaios de reologia, foi determinado pela média ponderada entre os valores obtidos para cada matéria-prima.

3) O teor de dispersante foi aumentado a cada $0,10 \%$, adicionado na mistura com uma seringa de $10 \mathrm{ml}$. A cada nova adição de dispersante, a pasta foi misturada na furadeira 
sob altas taxas de cisalhamento durante $2 \mathrm{~min}$, para promover alta dispersão dos particulados.

4) Após a mistura, a pasta foi submetida ao ensaio de Funil de Marsh. O tempo de escoamento para preencher o recipiente graduado em $400 \mathrm{ml}$ foi cronometrado para cada nova adição de dispersante, assim a dosagem ótima foi determinada por meio da estabilização do tempo ou quando sua variabilidade era insignificante (até $2 \mathrm{~s}$ de diferença).

5) Após o ensaio de Funil de Marsh, foi feito o espalhamento pelo minicone, onde o ponto de saturação de aditivo era atingido, quando os valores de fluidez (diâmetro de espalhamento) se estabilizavam ou apresentavam um aumento insiginificante (até $10 \mathrm{~mm}$ de diferença).

6) A dosagem ótima de dispersante foi admitida, quando os valores de tempo de escoamento no Funil de Marsh e espalhamento pelo minicone foram estabilizados.

\subsubsection{Procedimentos de moldagem dos corpos de prova das pastas}

Antes da moldagem dos corpos de prova destinados aos ensaios de resistência mecânica, foram avaliados os comportamentos reológicos de cada dosagem com os teores ótimos de aditivo estabelecidos. Esses ensaios foram necessários para verificar se, já com o teor ótimo de dispersante adicionado e em curto período de ensaio, as pastas apresentam um comportamento semelhante ao observado nos ensaios de reologia anteriores, que exigiram um tempo maior de duração. Após os ensaios de reologia, a pasta foi colocada em formas cilíndricas de PVC rosqueável, previamente enceradas, nas dimensões de 35x70mm. As formas foram rosqueadas em um suporte de aço galvanizado, lubrificado com óleo (Figura 31) para facilitar a desmoldagem.

Figura 31 - Formas de PVC acopladas no suporte de aço

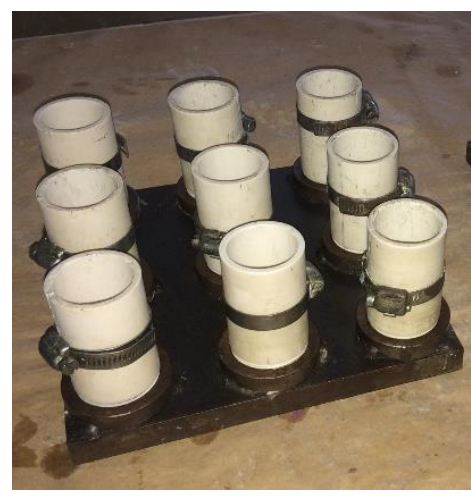

Fonte: Autora 
O suporte metálico com os corpos de prova foi encaixado em uma forma de madeira, onde foi acoplada uma tampa para vedação da face superior dos corpos de prova (Figura 32). Em seguida, os corpos de prova devidamente presos por porcas na forma de madeira, foram colocados em um cilindro de PVC e submetidos à rotação no roller mecânico (Figura 33).

Figura 32 - Corpos de prova fixados na forma de madeira

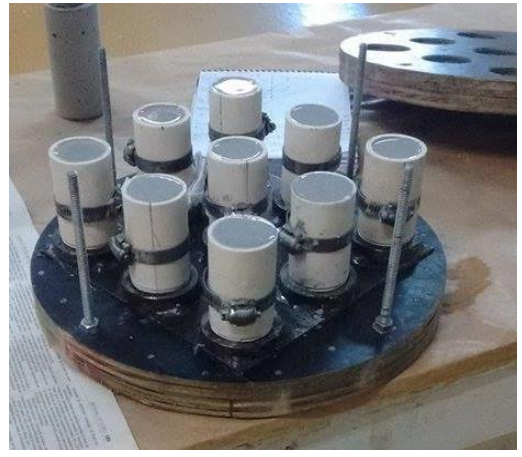

(a) Base metálica encaixada na forma de madeira

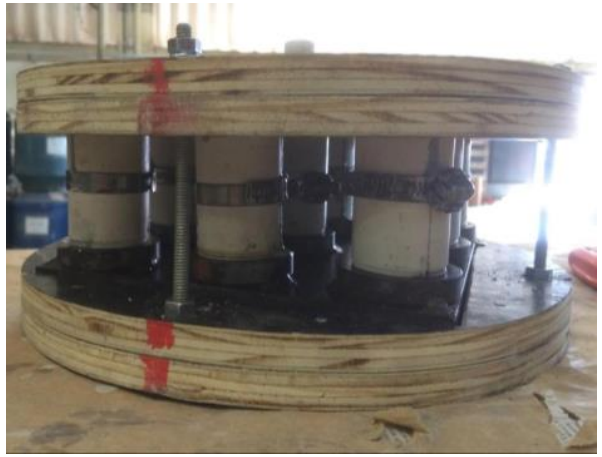

(b) Corpos de prova fixos na forma para rotação

Fonte: Autora

Figura 33 - Forma com os corpos de prova no roller mecânico

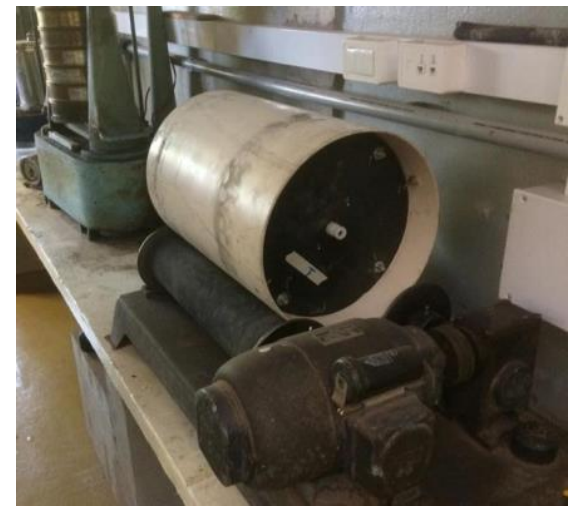

Fonte: Autora

O procedimento de rotação no roller, desenvolvido por Damineli, foi executado, visando atingir uma viscosidade que evite a segregação nos corpos de prova, pois a relação água/sólidos nas pastas é superior à utilizada em dosagens de argamassas e concretos. Após serem retirados do equipamento, os corpos de prova foram levemente misturados para retirar as bolhas de ar formadas durante a rotação (Figura 34). O tempo de rotação foi fixado entre 20 e 30min, pois em tempos inferiores a viscosidade ideal não seria atingida, havendo segregação da mistura, principalmente as com maiores teores de água. Já em tempos superiores, o processo de endurecimento dos corpos de prova, devido ao início das reações de hidratação do cimento, dificultaria a retirada das bolhas de ar. 
Figura 34 - homogeneização dos corpos de prova após rotação

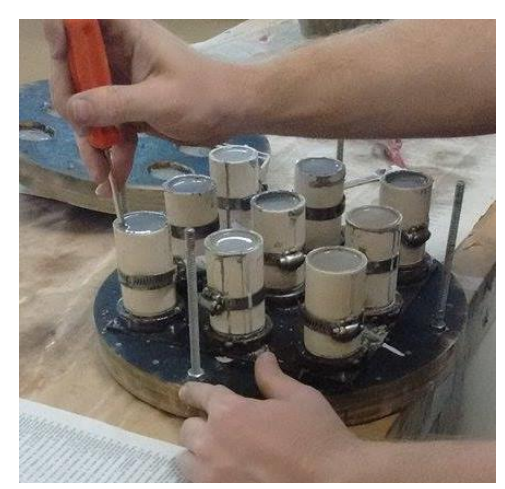

Fonte: Autora

Os corpos de prova foram transferidos para cura úmida, desmoldados com 1 dia e colocados submersos em câmara úmida (95\% de umidade) até o momento do ensaio de compressão. No período antecedente ao ensaio de resistência à compressão, as amostras foram retificadas.

\subsubsection{Procedimentos de moldagem dos corpos de prova das argamassas}

Para moldagem dos corpos de prova de argamassas foram utilizadas formas cilíndricas de dimensões $3,30 \mathrm{~cm}$ x $6,80 \mathrm{~cm}$, previamente lubrificadas com óleo mineral. Foram moldadas 6 amostras destinadas aos ensaios de resistência à compressão nas idades de 7 e 28 dias, sendo 3 para cada idade (Figura 35a e 35b). Os corpos de prova foram desmoldados após 24h e colocados em câmara úmida até a data do rompimento. Além disso, foram moldadas 2 amostras para cada dosagem, de dimensões $2,5 \mathrm{~cm}$ x $10,5 \mathrm{~cm}$ para os ensaios de determinação do módulo de elasticidade (Figura 35c).

Figura 35 - Corpos de prova de argamassas

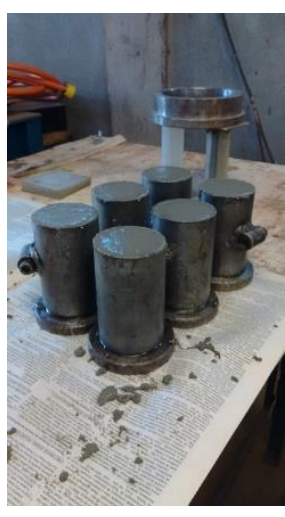

(a) Formas com argamassa

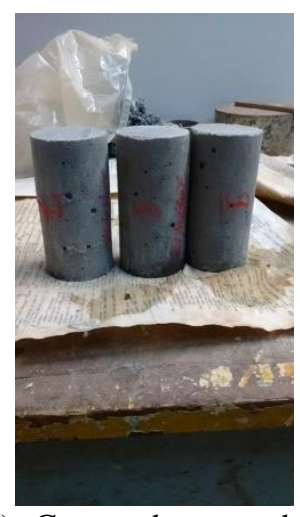

(b) Corpos de prova de argamassa

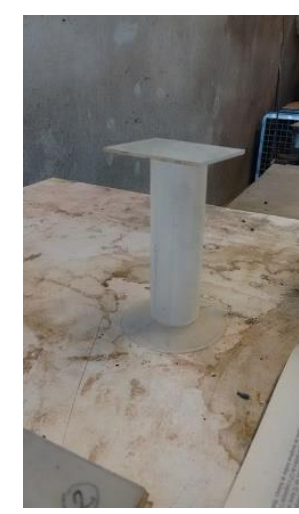

(c) Forma para ensaio de Módulo de Elasticidade

Fonte: Autora 


\subsubsection{Resistência Mecânica}

Nas segunda e terceira etapas da pesquisa, foram feitos ensaios de resistência mecânica dos corpos de prova de acordo com a NBR7215/1996, moldados com pastas e argamassas de cimento puro e cimento-fíler, respectivamente, conforme as dosagens indicadas no tópico de composições (Tabelas 5 e 6). Foram medidas as resistências à compressão uniaxial das amostras com idades de 7 e 28 dias, sendo 3 para cada idade. Foi utilizada a prensa eletromecânica Amsler (Figura 36) com velocidade de aplicação de carga $(0,25 \pm 0,05) \mathrm{MPa} / \mathrm{s}$.

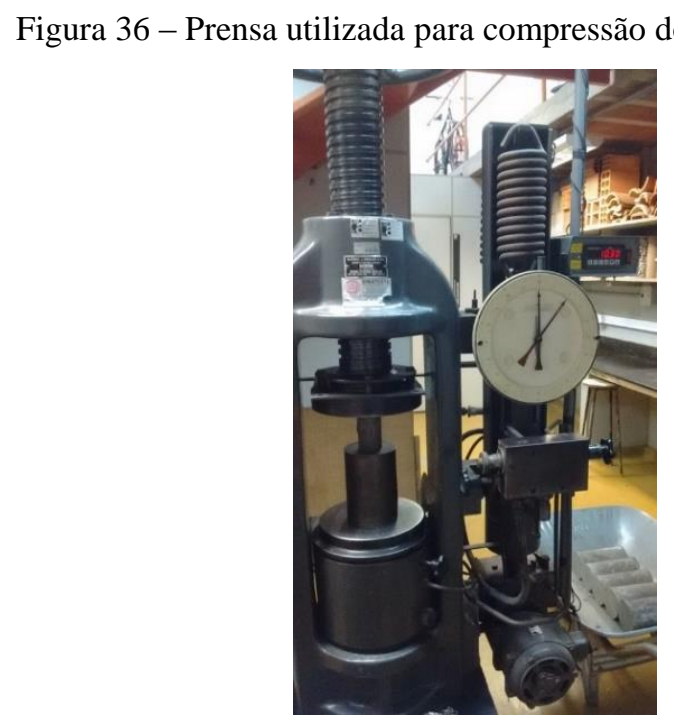

Fonte: Autora

\subsubsection{Módulo de Elasticidade}

O modulo de elasticidade flexural dos corpos de prova de argamassas foi determinado através da técnica de excitação por impulso, utilizando o equipamento Sonelastic desenvolvido pela ATCP Engenharia Física, atendendo à norma ASTM E1876-15. O método consiste em provocar um impulso mecânico na amostra, por meio de uma leve batida, enquanto um microfone capta a frequência de som emitida e sua atenuação, enviando os dados para o software que calcula os módulos de elasticidade (Figura 37). Foram moldados 2 corpos de prova para cada mistura de argamassa, com dimensões $25 \mathrm{~mm}$ de diâmetro e $105 \mathrm{~mm}$ de altura (Figura 38). 
Figura 37 - Mecanismo de funcionamento da Técnica de Excitação por Impulso

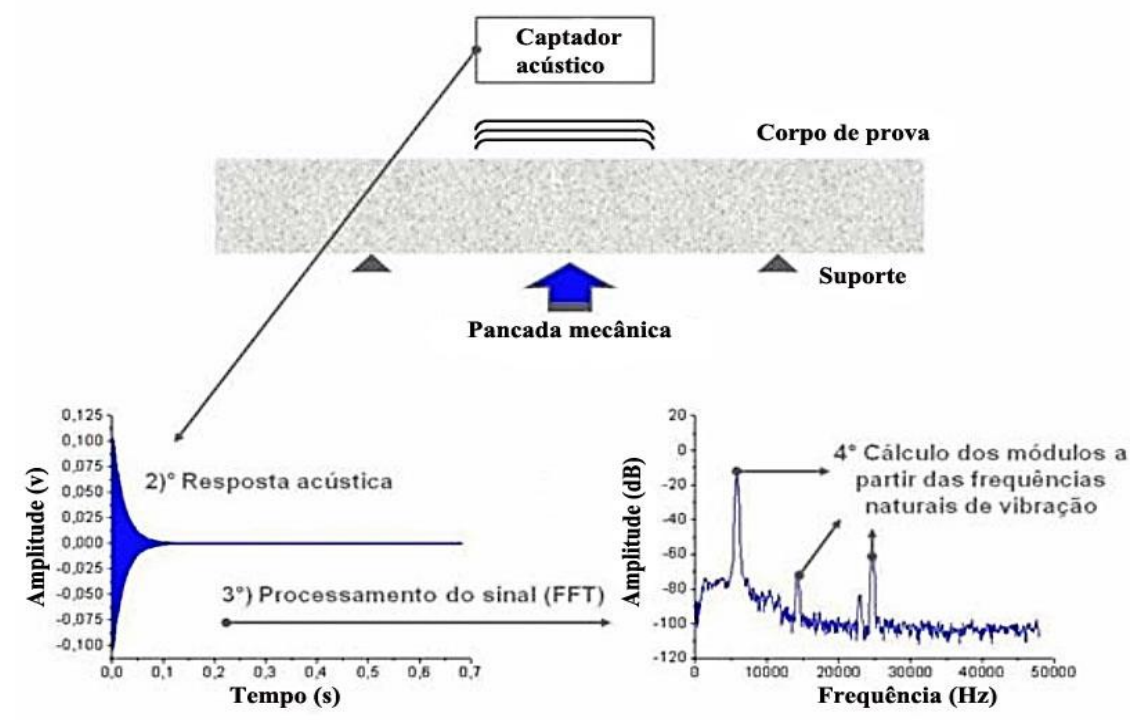

Fonte: ATCP Engenharia Fís

Figura 38 - Equipamento Sonelastic ATCP Engenharia Física

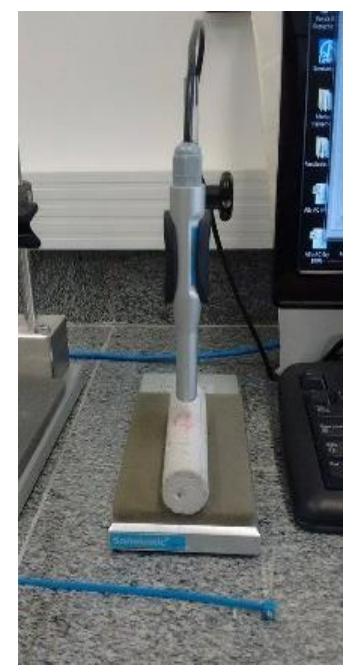

(a) Captador acústico

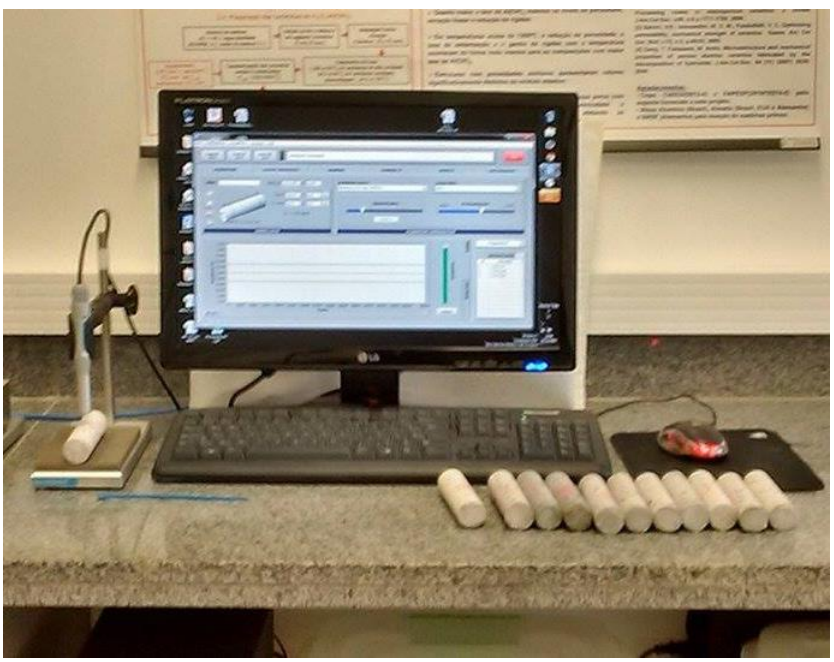

(b) Equipamento, software e corpos de prova

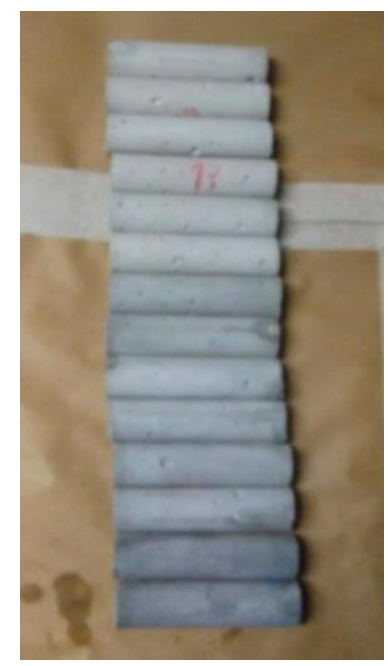

(c) Corpos de prova

Fonte: Autora

\subsubsection{Cálculo do Índice de Eficiência (BI)}

O índice Binder Intensity (BI) determina a quantidade de ligante necessária para atingir a resistência de $1 \mathrm{MPa}$. O cálculo de eficiência consiste em dividir o consumo de cimento (C) em volume $\left(\mathrm{kg} / \mathrm{m}^{3}\right)$ pela resistência mecânica média $(\sigma)$ atingida aos 28 dias, determinando a porcentagem de ganho ou perda de eficiência das amostras em relação a de referência. 
(DAMINELI et al., 2010). Primeiramente calcula-se o valor do BI do material de cimento puro, que possui índice de eficiência nulo. Em seguida, determina-se o valor do BI para as misturas com fíleres, que para cálculo do índice de eficiência, deve ser subtraído pelo BI do material convencional. O valor calculado na subtração é dividido pelo BI da mistura de CPV e multiplicado por 100, gerando o resultado em porcentagem.

$$
\begin{aligned}
& \frac{\mathrm{C}}{\sigma}=B I \\
& B I_{C P V}-B I_{\text {filer }}=x \\
& \frac{x}{B I_{C P V}} 100=\% \text { Eficiência }
\end{aligned}
$$




\section{$5 \quad$ RESULTADOS E DISCUSSÕES}

Neste item serão apresentados e discutidos os resultados referentes aos ensaios realizados com as pastas e argamassas produzidas. Na primeira fase da pesquisa foram feitas comparações entre os comportamentos reológicos das pastas e os valores de resistência mecânica, a fim de produzir um material com características reológicas que possibilitem a redução do teor de água incorporado para aumentar a resistência sem a necessidade de uma grande quantidade de clínquer como ligante. A última etapa de ensaios envolveu a avaliação das argamassas feitas com as pastas analisadas, visando calcular o ganho de eficiência dos materiais produzidos, através do índice Binder Intensity (BI), que relaciona o ganho de resistência do material com o teor de cimento consumido.

\subsection{CARACTERIZAÇ̃̃o DAS MATÉRIAS-PRIMAS}

A caracterização química das matérias-primas, determinadas por fluorescência de raios $\mathrm{X}$, demonstrou que os três fíleres selecionados são compostos por $99 \%$ de $\mathrm{SiO}_{2}$.

\subsubsection{Distribuição Granulométrica}

Os gráficos das Figuras 39 e 40 mostram as curvas de composição granulométrica discreta e acumulada dos fíleres, respectivamente. O fíler SM400 é composto por partículas de menores dimensões, o SM325 intermediárias e o SM200 com partículas maiores. Os gráficos das Figura 41 e 42 mostram as curvas discreta e acumulada, respectivamente, da composição granulométrica da areia grossa AJ6 utilizada nas misturas de argamassas.

Figura 39 - Composição Granulométrica dos fíleres, curva discreta

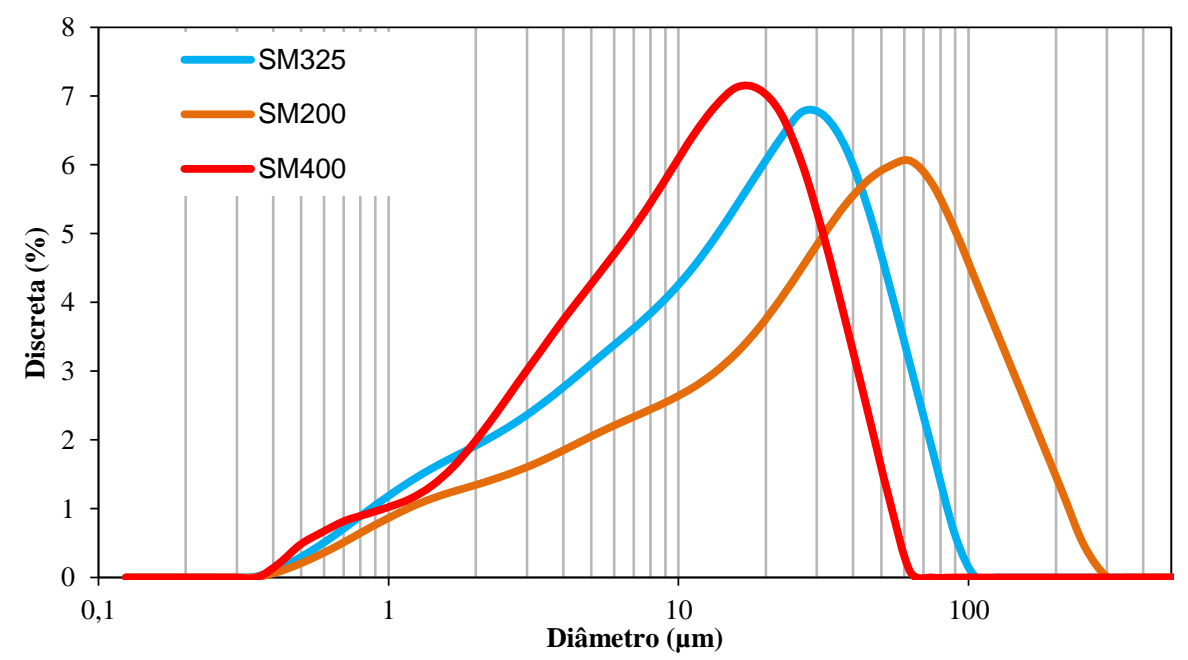


Figura 40 - Composição granulométrica dos fíleres, porcentagem acumulada

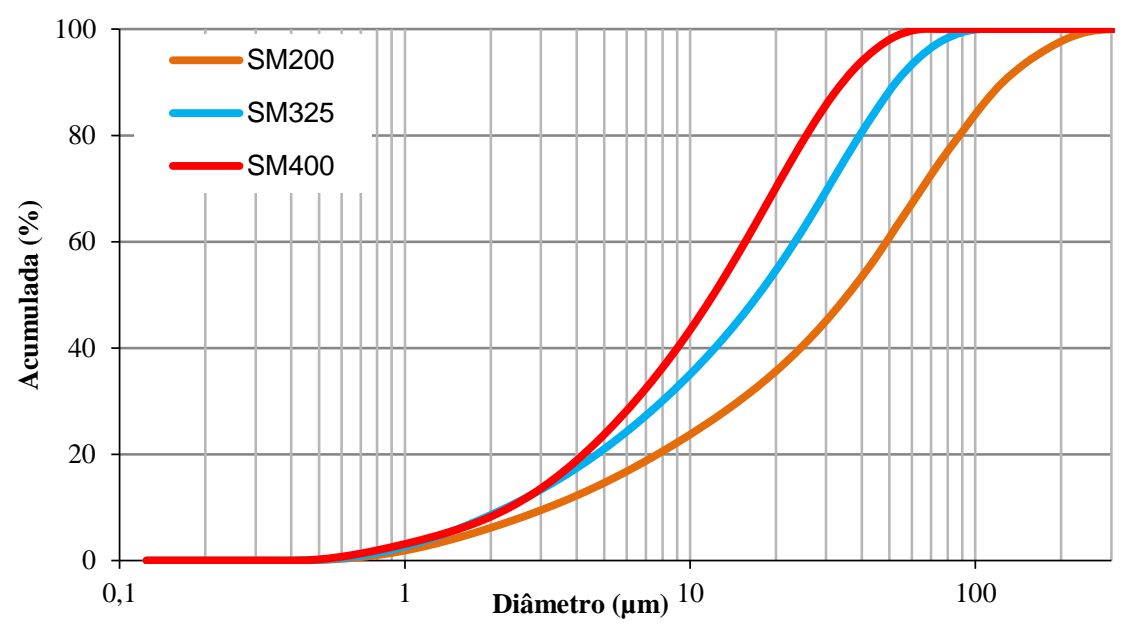

Figura 41 - Composição granulométrica da areia (AJ6), curva discreta.

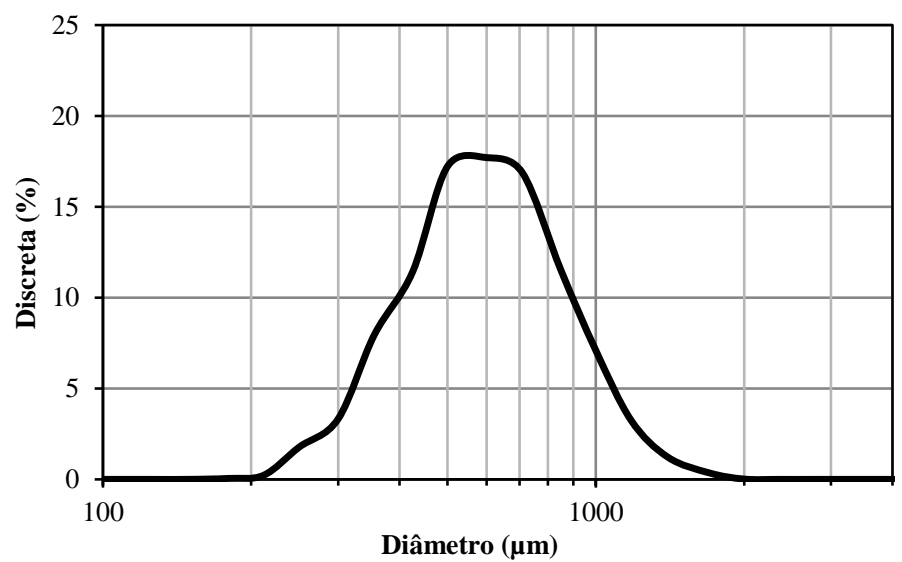

Fonte: Baeta (2016).

Figura 42 - Composição granulométrica da areia (AJ6), porcentagem acumulada

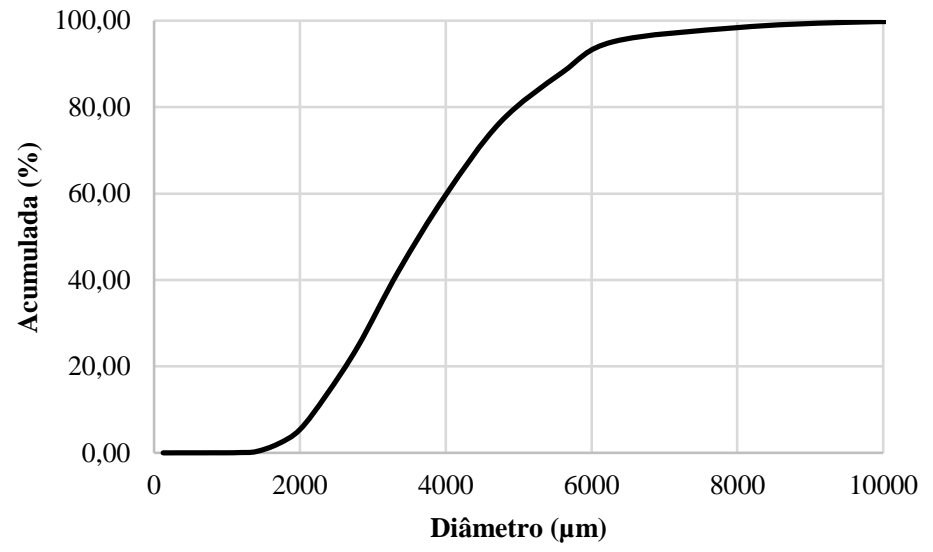

Fonte: Baeta (2016) 
A Tabela 7 contém os diâmetros em micrometros $(\mu \mathrm{m})$ para os parâmetros D10, D90, que são os diâmetros de corte das curvas de distribuição acumuladas em 10\% e 90\%, e D50, correspondente aos diâmetros médios das partículas.

Tabela 7 - D10, D50 e D90 das matérias-primas em $\mu \mathrm{m}$

\begin{tabular}{ccccc}
\hline \multicolumn{5}{c}{ Diâmetro $(\boldsymbol{\mu m})$} \\
\hline Material & SM200 & SM325 & SM400 & AJ6 \\
\hline D10 & 3,34 & 2,36 & 2,36 & - \\
\hline D50 & 37,84 & 18,92 & 13,37 & 656,5 \\
\hline D90 & 125 & 53 & 37,84 & - \\
\hline
\end{tabular}

\subsection{2 Área Superficial e Fator Forma}

Os dados de composição granulométrica e a determinação da área superficial permitem calcular o fator forma $(\mathrm{FF})$ das partículas dos fíleres. Esse parâmetro indica a proximidade da morfologia real das partículas de um formato esférico perfeito de mesmo diâmetro. Uma esfera perfeita, sem rugosidades, é indicada por um FF de valor 1, portanto, quanto maior o FF, menor a angulosidade e rugosidade das partículas. Grãos com FF próximos a 1 exigem menores teores de água e de dispersante para atingir fluidez, contribuindo com o empacotamento (redução da porosidade) e aumento da resistência do material (DAMINELI, 2013).

O cálculo do FF foi feito através das seguintes etapas:

a) Cálculo da área superficial volumetrica (VSA):

$$
\begin{aligned}
& A p=\pi \emptyset^{2} \\
& V p=\frac{\pi \emptyset^{3}}{6} \\
& V S A=\sum \frac{A p x \% \text { distr.gran. }}{V p}
\end{aligned}
$$

Onde:

$\emptyset=$ raio da partícula esférica

Ap = área superficial teórica de cada diâmetro de partículas encontrado na distribuição granulométrica

\%distrib. Gran. = percentual do diâmetro de partículas encontrado na distribuição granulométrica

$\mathrm{Vp}=$ volume teórico da partícula 
b) Cálculo da área superficial teórica (SSA):

$S S A_{\text {teórica }}=\frac{V S A}{\gamma}$

Onde:

VSA = área superficial volumétrica

$\gamma=$ densidade sólido

c) Cálculo do fator forma (FF)

$F F=\frac{S S A_{\text {medida }}}{S S A_{\text {teórica }}}$

Onde:

$S S A_{\text {medida }}=$ valor determinado pelo ensaio de BET

Os resultados dos cálculos para o FF dos fíleres (Tabela 8), mostram que os três apresentam valores muito semelhantes, o que significa formato mais distante do esférico ou certa rugosidade superficial. O fíler SM400 apresentou maior FF e maior área superficial que os demais, mostrando uma tendência a exigir maiores teores de água e dispersante. Os fíleres SM200 e SM325 apresentam FF semelhantes, porém o SM200 possui menor área superficial, tendendo a exigir menor teor de água e de dispersante. A proximidade entre os valores de FF condiz com o fato de os três fíleres serem de mesma origem. A Tabela 8 contém os resultados das avaliações da densidade, área superficial e fator forma das matérias-primas.

Tabela 8 - Densidade, Área Superficial e Fator Forma

\begin{tabular}{|c|c|c|c|}
\hline Material & Densidade $\left(\mathrm{kg} / \mathrm{dm}^{3}\right)$ & Área superficial $\left(\mathrm{m}^{2} / \mathrm{g}\right)$ & Fator de Forma \\
\hline CP V & 3,03 & 1,72 & 5,14 \\
\hline SM200 & 2,65 & 0,89 & 3,10 \\
\hline SM325 & 2,65 & 1,26 & 3,11 \\
\hline SM400 & 2,65 & 1,67 & 3,66 \\
\hline AJ6 & 2,63 & - & - \\
\hline
\end{tabular}




\subsection{COMPORTAMENTO REOLÓGICO}

A seguir são apresentados os resultados dos ensaios de comportamento reológico das pastas feitas com as matérias-primas puras e cimento-fíler, gráficos mostrando o desvio padrão e tempo de trabalhabilidade das misturas.

\subsubsection{Pastas de cimento}

Para as pastas de cimento puro, foram feitas dosagens com os teores de água 0,21-0,230,25, determinando os teores ótimos de aditivo para cada mistura. A Figura 43, a seguir, mostra os resultados dos ensaios de Funil de Marsh de acordo com o aumento do teor de dispersante. Os pontos em destaque indicam os teores ótimos.

Figura 43 - Teor de aditivo x Tempo de Marsh para as pastas de cimento

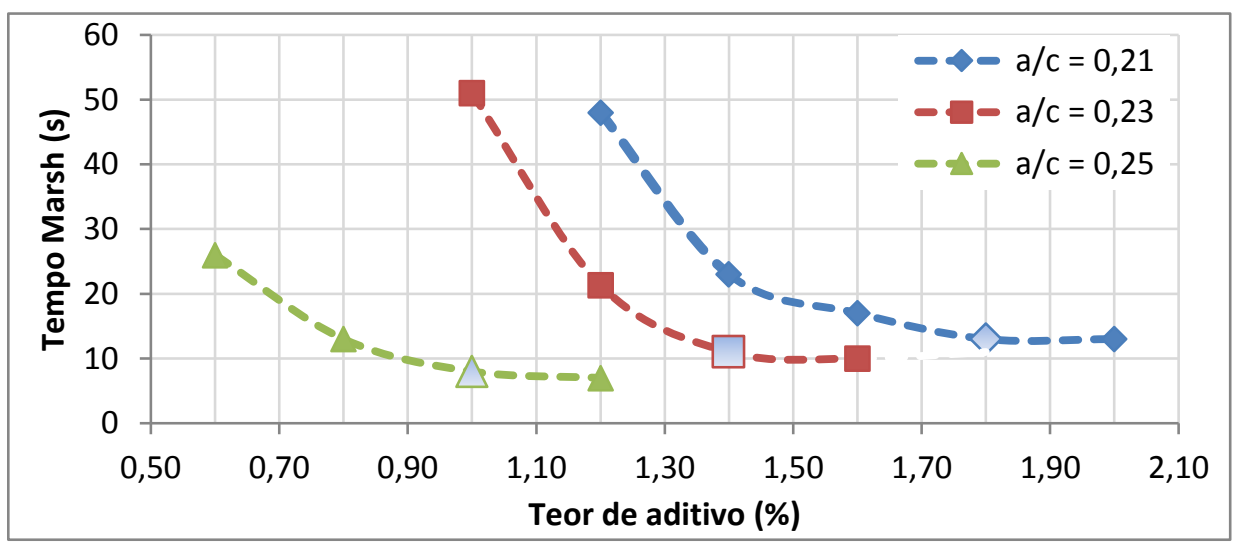

Segundo o gráfico acima, o tempo de escoamento das pastas no Funil de Marsh para os teores ótimos de aditivo foram: 1) $13 \mathrm{~s}$ para a pasta com fator a/c 0,21, com teor de aditivo $1,80 \%, 2) 11 \mathrm{~s}$ para a pasta com fator a/c 0,23 , com teor de aditivo $1,40 \%, 3) 8 \mathrm{~s}$ para a pasta com fator a/c 0,25 , com teor de aditivo $1,00 \%$. Para seleção do ponto ótimo, as misturas foram consideradas estabilizadas quando a diferença no tempo de escoamento era menor do que $2 \mathrm{~s}$. De acordo com o gráfico, é possível observar que quanto maior o teor de água da mistura, menor é a quantidade de aditivo necessária para afastar os particulados e menor é a viscosidade da pasta (menor tempo de escoamento pelo funil).

A seguir, a Figura 44 mostra os resultados dos ensaios de espalhamento pelo minicone de acordo com o aumento do teor de dispersante. 
Figura 44 - Teor de aditivo x Espalhamento para as pastas de cimento

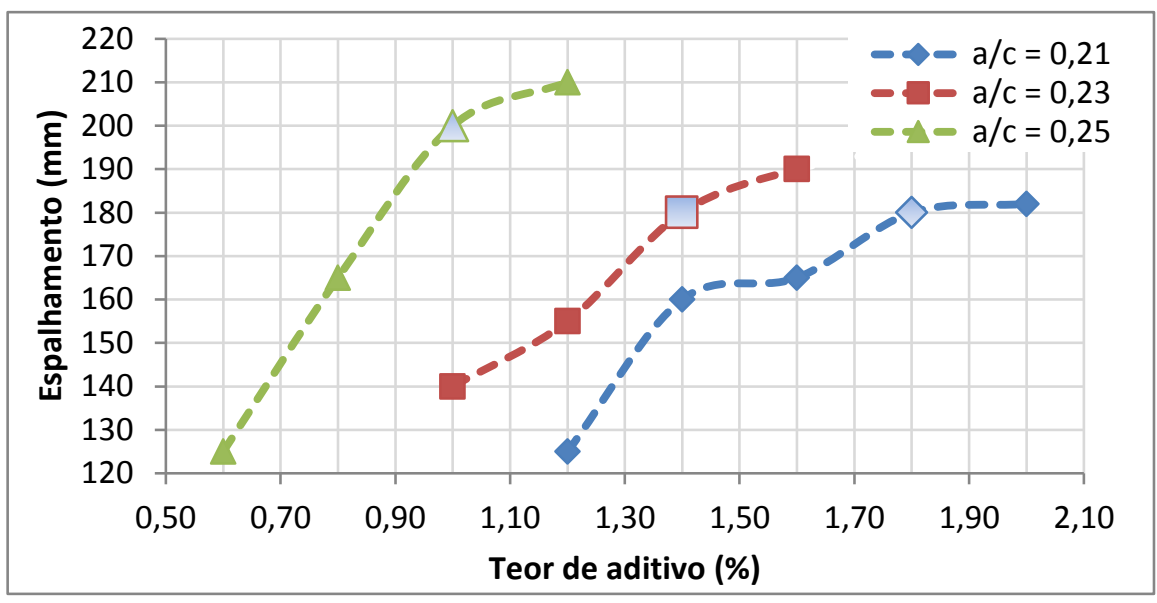

De acordo com o gráfico, os diâmetros de espalhamento atingidos pelas pastas para os teores ótimos de aditivo foram: 1) $180 \mathrm{~mm}$ para a pasta com fator a/c 0,21, com teor de aditivo $1,80 \%, 2) 180 \mathrm{~mm}$ para a pasta com fator a/c 0,23 , com teor de aditivo $1,40 \%$, 3) $200 \mathrm{~mm}$ para a pasta com fator a/c 0,25 , com teor de aditivo $1,00 \%$. Nota-se que o espalhamento é superior na dosagem com maior teor de água teor de água $(0,25)$ e, embora a pasta com teor de água 0,23 tenha atingido o mesmo espalhamento que a pasta com teor 0,21 (no ponto de saturação do dispersante), a mistura com menor teor de água necessitou de maiores quantidades de dispersante.

É importante salientar que, apesar de atingidos os pontos ótimos de dispersante, houve aumento no espalhamento das pastas, porém o valor absoluto de aumento é baixo $(10 \mathrm{~mm}$ de diferença), sendo considerado pouco significativo. Além disso, nos pontos de saturação selecionados, os valores para os ensaios de Funil de Marsh foram estabilizados, indicando que a adsorção de dispersante na superfície das partículas já estava completa. Logo, atingido o ponto de saturação, o aumento da adição de dispersante não influencia na viscosidade da suspensão, podendo criar uma camada flutuante que implica na segregação dos componentes da mistura.

\subsubsection{Pastas de filer de quartzo}

Para as misturas com fíler de quartzo, foram utilizadas três diferentes granulometrias, sendo a mais fina SM400, a intermediária SM325 e a mais grossa SM200. Os teores de água foram variados de acordo com o comportamento do fíler em meio aquoso, juntamente com a determinação do teor ótimo de aditivo dispersante. Assim, foram feitas misturas com os teores de água 0,30 e 0,33, pois o fíler de quartzo exigiu maiores quantidades de água para homogeneização da mistura e execução dos ensaios de reologia. 


\subsubsection{Fator a/s 0,30}

As pastas com teor de água 0,30 tiveram resultados divergentes nos ensaios de Funil de Marsh, sendo observado um aumento na viscosidade da mistura quando submetida às altas taxas de cisalhamento, mesmo com a adição de mais dispersante. A Figura 45 mostra o gráfico referente aos resultados dos ensaios de Funil de Marsh.

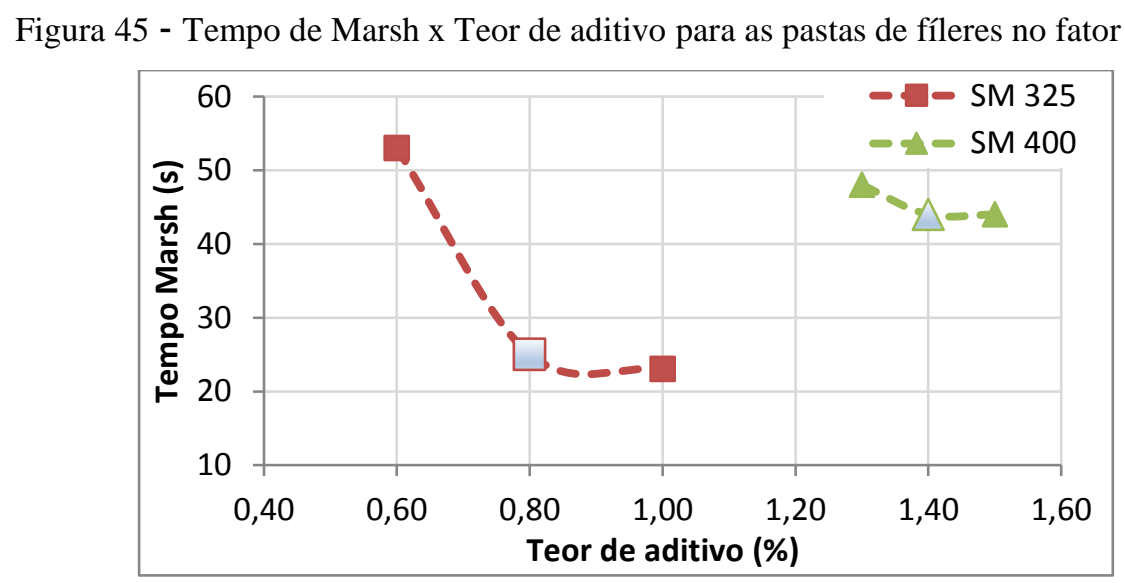

De acordo com o gráfico acima, o fíler SM200, mesmo sendo misturado sem adição de dispersante (teor de aditivo inicial 0) e com aumento da adição a cada 0,10\%, não apresentou escoamento pelo funil (tempo de escoamento infinito), mesmo aumentando o teor de dispersante e, portanto, não aparece no gráfico. O teor ótimo de aditivo adotado para o fíler SM325 foi 0,80\% com tempo de escoamento de 25s, para o fíler SM400 foi adotado 1,40\% com tempo de 44 s. Os teores ótimos foram determinados com base na estabilização do tempo ou quando este apresentou baixa variabilidade (até $2 \mathrm{~s}$ de diferença).

O fíler com granulometria mais grossa (SM200) apresentou um tempo de escoamento pelo Funil de Marsh considerado infinito (maior que 2min). Os demais fíleres, com granulometria inferior (portanto, com maior tendência à floculação) apresentaram tempos de escoamento menores que 1min. Por este motivo, os dados do SM200 não foram apresentados no gráfico. Entretanto, embora as pastas tenham apresentado alta viscosidade nos ensaios de Funil de Marsh, devido à maior tendência de floculação na suspensão sob altas taxas de cisalhamento, nos ensaios de espalhamento pelo minicone, observou-se que as misturas com as três granulometrias apresentaram baixa tensão de escoamento, atingindo altos valores de espalhamento. A Figura 46 mostra o gráfico comparativo entre os resultados de espalhamento de acordo com o aumento do teor de aditivo. 
Figura 46 - Teor de aditivo x Espalhamento para pastas de quartzo com a/s 0,30

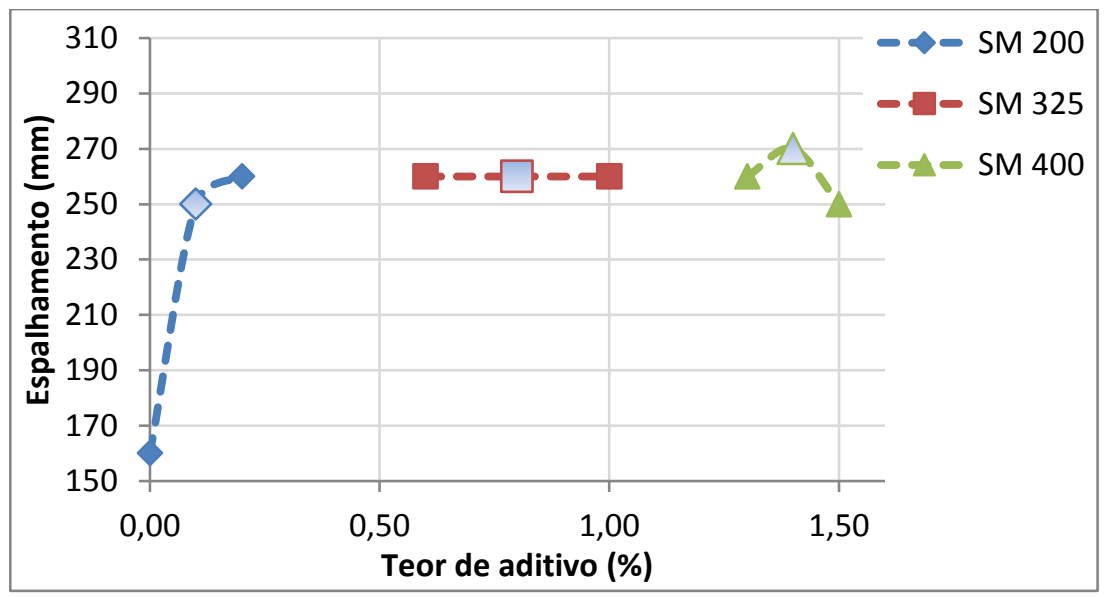

Os pontos destacados indicam os espalhamentos nos teores ótimos determinados para cada mistura, sendo: 0,10\% para o SM200 com espalhamento de $250 \mathrm{~mm}$, embora não tenha apresentado escoamento pelo Funil de Marsh; 0,80\% para o SM325 com espalhamento de $260 \mathrm{~mm}$, que embora tenha estabilizado no ensaio de minicone (desde o teor $0,60 \%$ ), foi estabilizada no Funil de Marsh com o teor de aditivo 0,80\%; e 1,40\% para o SM400 com espalhamento de $270 \mathrm{~mm}$, que sofreu uma redução de $20 \mathrm{~mm}$ com o aumento do teor de aditivo, mesmo estabilizado no Funil de Marsh.

É possível observar que a pasta com fíler de granulometria mais fina (SM400) necessitou de maiores quantidades de dispersante, demonstrando que quanto maior a finura do material, maior é o teor de aditivo necessário para afastar as partículas e diminuir a viscosidade da suspensão. 


\subsubsection{Fator a/s 0,33}

A Figura 47 mostra o gráfico com os resultados obtidos no ensaio de Funil de Marsh para as três granulometrias de fíleres no teor de água 0,33 .

Figura 47- Tempo de Marsh x Teor de aditivo para as pastas de fíleres no fator a/s 0,30

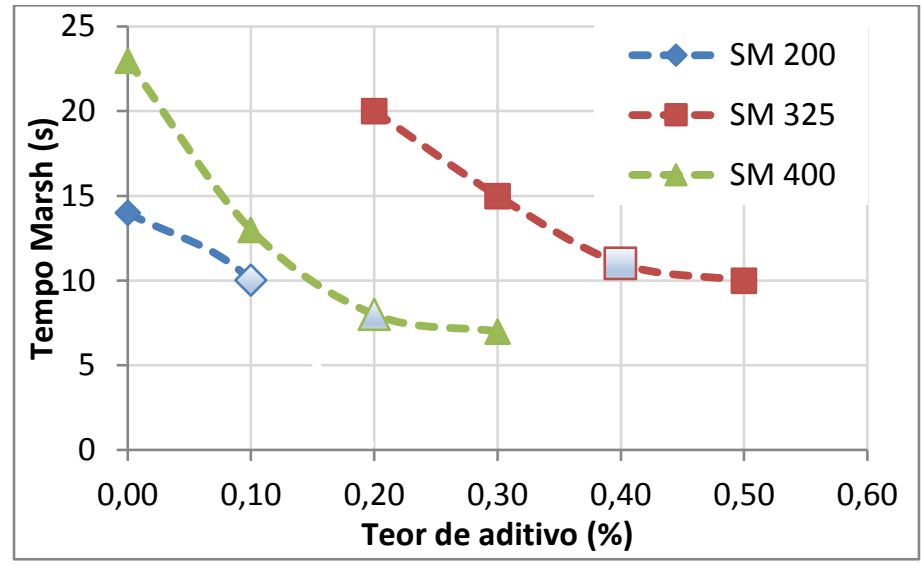

De acordo com o gráfico, o teor ótimo de aditivo para o fíler SM200 foi 0,10\% com tempo de escoamento de $10 \mathrm{~s}$, porém ao adicionar mais aditivo $(0,10 \%)$, a viscosidade da suspensão foi aumentada, impedindo o escoamento pelo funil. Esse fenômeno pode ter ocorrido, por excesso de dispersante no sistema, favorecendo a floculação por sobreposição de cadeias poliméricas adsorvidas na superfície das partículas dos fíleres. Por esse motivo, o terceiro ponto não foi representado no gráfico. Para o fíler SM325, o teor ótimo de dispersante foi $0,40 \%$ com tempo de escoamento de $11 \mathrm{~s}$ e para o fíler SM400, o teor ótimo foi 0,20 com tempo de 8s. Nota-se que, para esse teor de água, não houve relação entre a granulometria e a quantidade de aditivo incorporada na mistura para promover fluidez, pois o fíler de granulometria mais fina (SM400), exigiu menor teor de aditivo e menos tempo para escoar que o fíler de granulometria intermediária (SM325).

A Figura 48 mostra o gráfico comparativo entre os resultados de espalhamento de acordo a adição de dispersante para o teor de água 0,33 . 
Figura 48 - Teor de aditivo x Espalhamento para pastas de fíler de quartzo com a/s 0,33

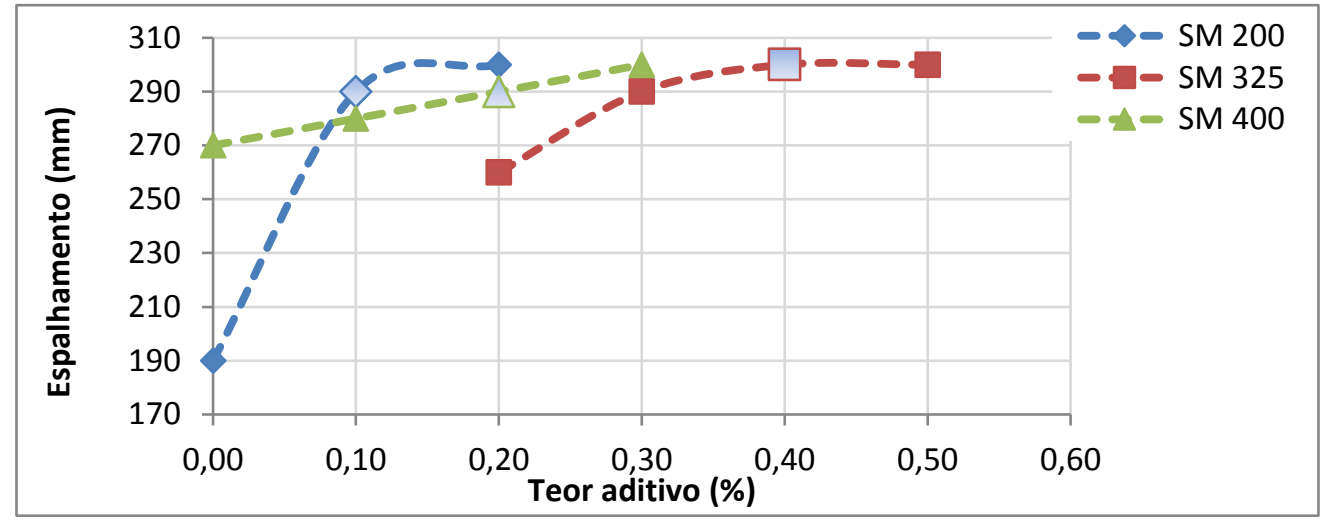

De acordo com o gráfico, o fíler SM200 atingiu um espalhamento de 290mm com 0,10\% de aditivo e, embora seu espalhamento tenha aumentado em 10mm (variação adotada como não significativa), não ocorreu escoamento pelo Funil de Marsh no terceiro ponto de adição de dispersante. Estes resultados demonstram que houve aumento na viscosidade da pasta sem afetar a tensão de escoamento. Já para o fíler SM325, o espalhamento foi de 300mm com teor de aditivo 0,40\% e para o fíler SM400, 0,20\% de aditivo e 290mm de espalhamento.

A realização dos ensaios com os fíleres de quartzo permitiu as seguintes conclusões:

1) A variação da granulometria dos fíleres de quartzo não influenciou no teor de aditivo e na viscosidade das pastas de forma previsível. O fíler SM200, mesmo sendo o de granulometria mais grossa, apresentou a maior viscosidade dentre os três estudados independentemente do teor de água. Ao aumentar o teor de dispersante, este fíler também apresentou aumento da viscosidade. O fíler SM400, por outro lado, apresentou menor fluidez do que o SM325 com teor de água 0,30, mas maior fluidez quando o teor de água foi aumentado para 0,33. Estas análises foram confirmadas por repetição de ensaios. As misturas contendo estes fíleres devem, portanto, ser estudadas caso a caso.

2) É possível observar que o aumento do teor de água contribuiu para a diminuição da viscosidade e da tensão de escoamento das misturas, fato que pode ser notado pela redução do tempo de escoamento no Funil de Marsh, pela diminuição do teor de aditivo e pelo aumento do espalhamento das pastas.

3) Em algumas pastas, o aumento do teor de dispersante foi ineficaz para reduzir a viscosidade, contribuindo para que se tornassem ainda mais viscosas (pasta SM200 com fator a/s 0,33), com impedimento ou redução do escoamento pelo Funil de Marsh. Este fenômeno pode ter relação com a sobreposição das moléculas de aditivo 
ou com a adsorção de uma mesma molécula de dispersante por duas partículas de fíler diferentes, que podem formar aglomerados e aumentar a viscosidade da suspensão.

4) Através dos ensaios de Funil de Marsh, foi possível verificar que os fíleres de quartzo apresentam comportamento dilatante em suspensão, pois quando são submetidos a altas tensões de cisalhamento a viscosidade é aumentada.

5) Nos ensaios realizados com o minicone, as pastas apresentaram grande espalhamento para ambos os teores de água, demonstrando que os materiais apresentam baixa tensão de escoamento quando submetidos a baixas tensões de cisalhamento. Através desse ensaio, foi possível observar a tendência à segregação dos componentes da suspensão com o aumento do teor de aditivo (Figura 49).

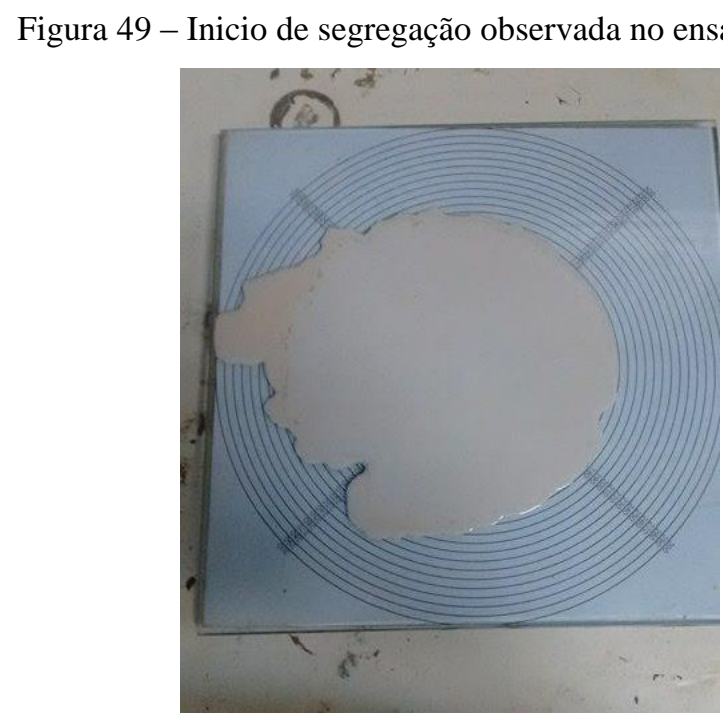

Fonte: Autor

\subsubsection{Pastas de clínquer-fíler}

A partir dos teores ótimos determinados nos ensaios feitos com as matérias-primas, foram estimados teores iniciais de dispersante para execução dos ensaios de reologia com as pastas de clínquer-fíler. Não foi possível calcular uma média entre os teores ótimos obtidos para cara material puro, como proposto inicialmente, pois os fíleres apresentaram comportamentos reológicos diferentes do cimento, impossibilitando o cálculo exato.

Foram feitas misturas substituindo $60 \%$ e $40 \%$ em volume de cimento por fíleres de quartzo nos mesmos teores de água que as pastas feitas com cimento, buscando alcançar um comportamento reológico semelhante ao material convencional. As dosagens foram feitas de acordo com a Tabela 5, presente no item "composições". Para análise dos dados, foram 
elaborados gráficos relacionando os resultados dos comportamentos reológicos das misturas para cada tipo de fíler, de acordo com a variação do teor de água e porcentagem de substituição. Além disso, foram gerados gráficos comparativos entre os resultados reológicos das substituições de $40 \%$ e $60 \%$ de fíler, e as pastas de cimento puro, para cada teor de água.

\subsubsection{Fíler SM200}

\section{A) Pastas $40 \%$ Fíler 60\% Cimento}

As Figuras 50 e 51 mostram os gráficos comparativos entre os resultados dos ensaios reológicos feitos com 40\% de fíler SM200 nos teores de água indicados. A Figura 50 compara os efeitos da adição de dispersante sobre o tempo de escoamento pelo Funil de Marsh, os pontos destacados indicam os teores ótimos de dispersante.

Figura 50 - Teor de aditivo x Tempo de Marsh para as pastas 40\% quartzo, na granulometria SM200

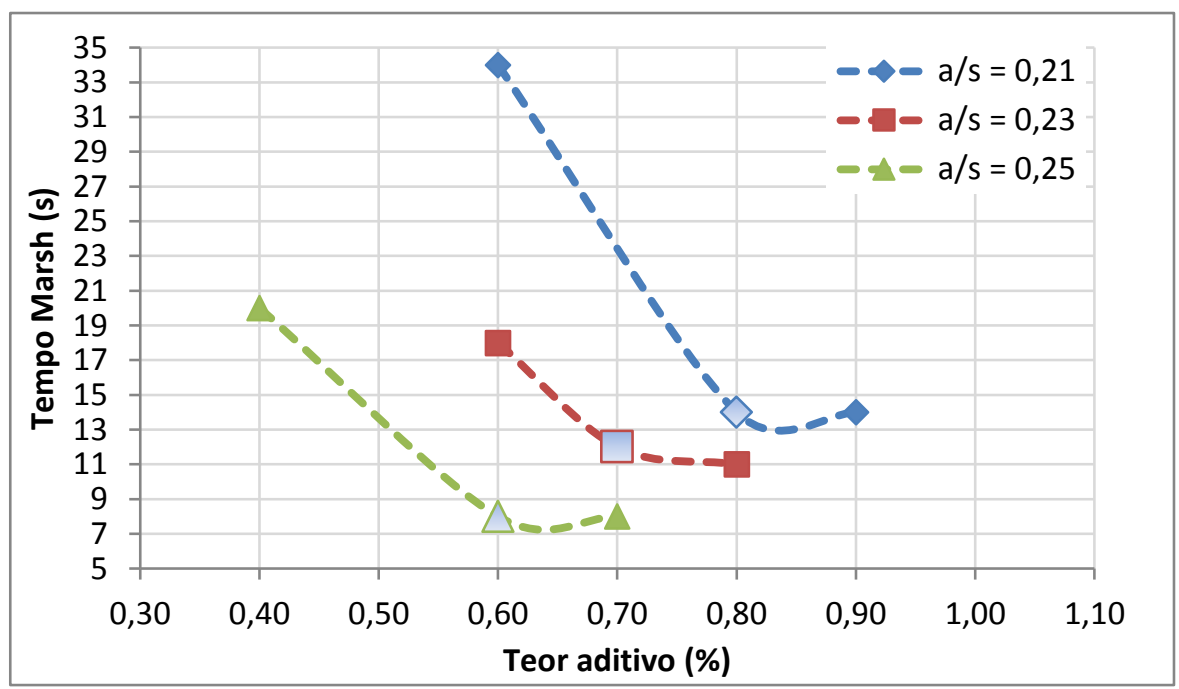

Segundo o gráfico acima, os teores ideais de aditivo para as pastas $\mathrm{x}$ tempo, foram: 1) $0,80 \%$ para a pasta com fator a/s 0,21 , com tempo de escoamento de $14 \mathrm{~s}, 2) 0,70 \%$ para a pasta com fator a/s 0,23, com tempo de escoamento de $12 \mathrm{~s}, 3$ ) $0,60 \%$ para a pasta com fator a/s 0,25 , com tempo de escoamento de 8s. De acordo com os resultados, a pasta com menor teor de água apresentou maior viscosidade, pois levou maior tempo para escoar que as demais e exigiu maior teor de dispersante para afastamento dos grãos.

Observação: embora tenha ocorrido diminuição do tempo após atingido o ponto de saturação (curva 0,23), tempos de até $2 \mathrm{~s}$ de diferença foram considerados irrelevantes para diminuição da viscosidade. 
A Figura 51 compara os efeitos do aumento do teor de dispersante sobre os espalhamentos das pastas, os pontos destacados indicam os teores ótimos de dispersante.

Figura 51 - Teor de aditivo x Espalhamento para as pastas 40\% quartzo, na granulometria SM200

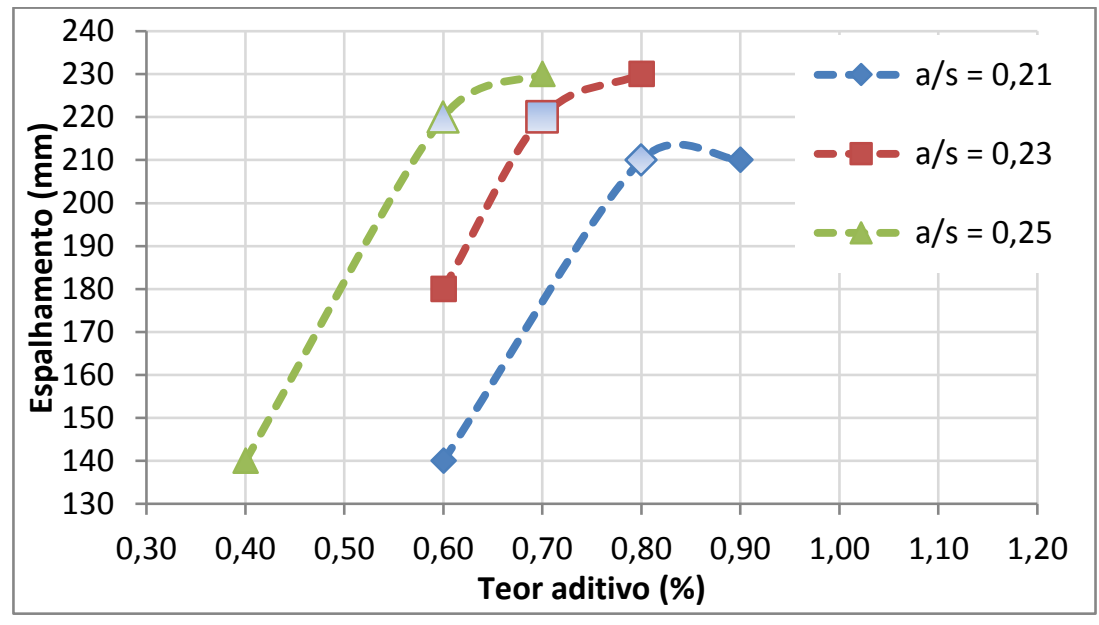

De acordo com o gráfico acima, os espalhamentos das pastas para os teores ótimos de aditivo, foram: 1) para a pasta com fator a/s 0,21 o diâmetro atingido foi de $210 \mathrm{~mm}$, com $0,80 \%$ de aditivo 2) para a pasta com fator a/s 0,23 o diâmetro atingido foi de $220 \mathrm{~mm}$, com $0,70 \%$ de aditivo 3) para a pasta com fator a/s 0,25 o diâmetro atingido foi de $220 \mathrm{~mm}$, com $0,60 \%$ de aditivo. Nota-se que a pasta com maior teor de água apresentou tensão de escoamento semelhante à com teor de água intermediário, porém exigiu uma quantidade menor de dispersante. A mistura com menor teor de água exigiu maiores quantidades de dispersante e apresentou maior tensão de escoamento que as demais, pois teve valores de espalhamento inferiores.

É importante salientar que, embora algumas curvas tenham aumentado após atingido o teor ótimo de dispersante, esse aumento foi considerado pouco significativo (até $10 \mathrm{~mm}$ ). Além disso, os valores do ensaio de Marsh para os teores de aditivo selecionados já haviam estabilizado, sendo mais importantes para a definição dos dados.

\section{B) Pastas $60 \%$ Fíler $40 \%$ Cimento}

As Figuras 52 e 53 mostram os gráficos comparativos entre os resultados dos ensaios reológicos feitos com $60 \%$ de fíler SM200 nos teores de água indicados. A Figura 52 compara os efeitos dos teores de aditivo adicionados sobre o tempo de escoamento pelo Funil de Marsh, os pontos destacados indicam os teores ótimos de dispersante. 
Figura 52- Teor de aditivo x Tempo de Marsh para as pastas 60\% quartzo na granulometria SM200

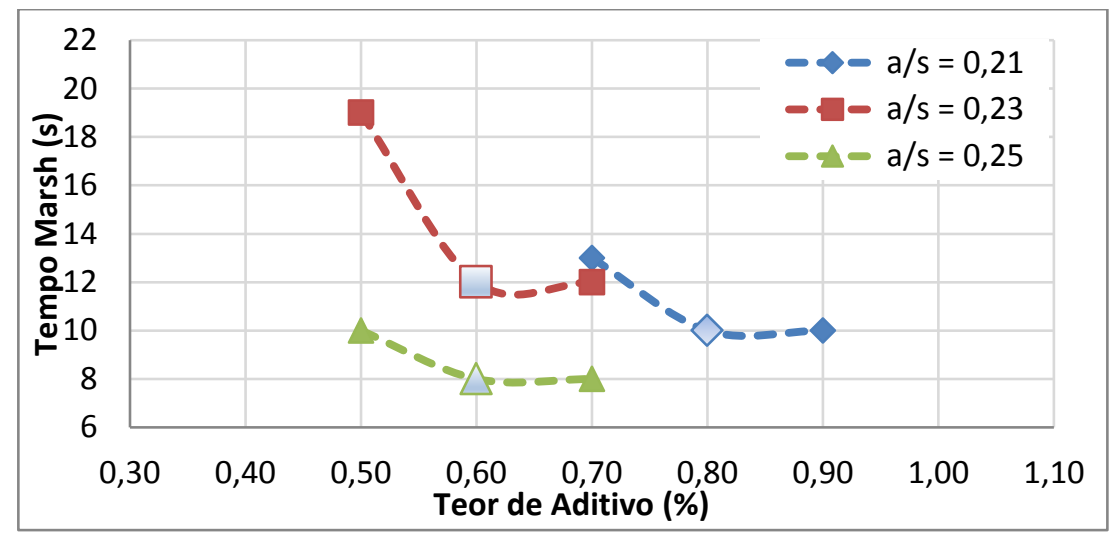

Segundo o gráfico acima, os teores ótimos de aditivo para as pastas x tempo, foram: 1) $0,80 \%$ para a pasta com fator a/s 0,21 , com 10 s de escoamento, 2) $0,60 \%$ para a pasta com fator a/s 0,23, com 12s de escoamento, 3) 0,60\% para a pasta com fator a/s 0,25, com 8s de escoamento. Observa-se que a pasta com menor teor de água $(0,21)$ exigiu maior quantidade de aditivo para escoar, comparada às demais. Porém, a pasta com teor de água intermediário $(0,23)$, embora tenha exigido a mesma quantidade de aditivo que a pasta com teor de água 0,25, apresentou viscosidade superior às demais.

A Figura 53 compara o teor de aditivo adicionado com o espalhamento atingido pelo ensaio de minicone.

Figura 53 - Teor de aditivo x Espalhamento para as pastas 60\% quartzo na granulometria SM200

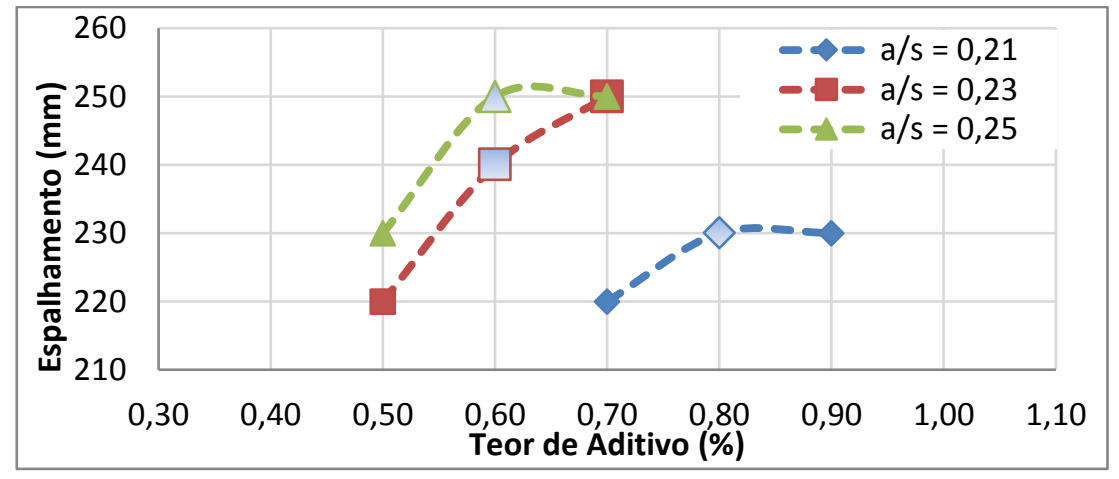

De acordo com o gráfico acima, os espalhamentos atingidos pelas pastas nos teores ótimos de dispersante, foram: 1) 230mm para a pasta com fator a/s 0,21, com teor de aditivo $0,80 \%, 2) 240 \mathrm{~mm}$ para a pasta com fator a/s 0,23 , com teor de aditivo $0,60 \%$, 3) $250 \mathrm{~mm}$ para a pasta com fator a/s 0,25 , com teor de aditivo $0,60 \%$. Observa-se que a pasta com menor teor de água obteve um espalhamento inferior às demais, indicando que apresenta maior tensão de escoamento. A pasta com teor de água intermediário, embora tenha apresentado maior viscosidade em relação às outras, apresentou um comportamento referente à tensão de 
escoamento semelhante à mistura com maior teor de água, pois a variação de valores de $10 \mathrm{~mm}$ foi considerada não significativa. Logo, o aumento no diâmetro de espalhamento observado na pasta 0,23 (de $240 \mathrm{~mm}$ para $250 \mathrm{~mm}$ ) foi irrelevante, visto que os valores de Marsh já estavam estabilizados para esse ponto.

\subsubsection{Fíler SM325}

\section{A) Pastas $40 \%$ Fíler $60 \%$ Cimento}

As Figuras 54 e 55, mostram os gráficos comparativos entre os resultados dos ensaios de reologia feitos com $40 \%$ de fíler SM325 nos teores de água indicados. Abaixo, a Figura 54 compara os efeitos dos teores de aditivo adicionados sobre o tempo de escoamento pelo Funil de Marsh, os pontos destacados indicam os teores ótimos de dispersante.

Figura 54 - Teor de aditivo x Tempo de Marsh para as pastas 40\% quartzo na granulometria SM325

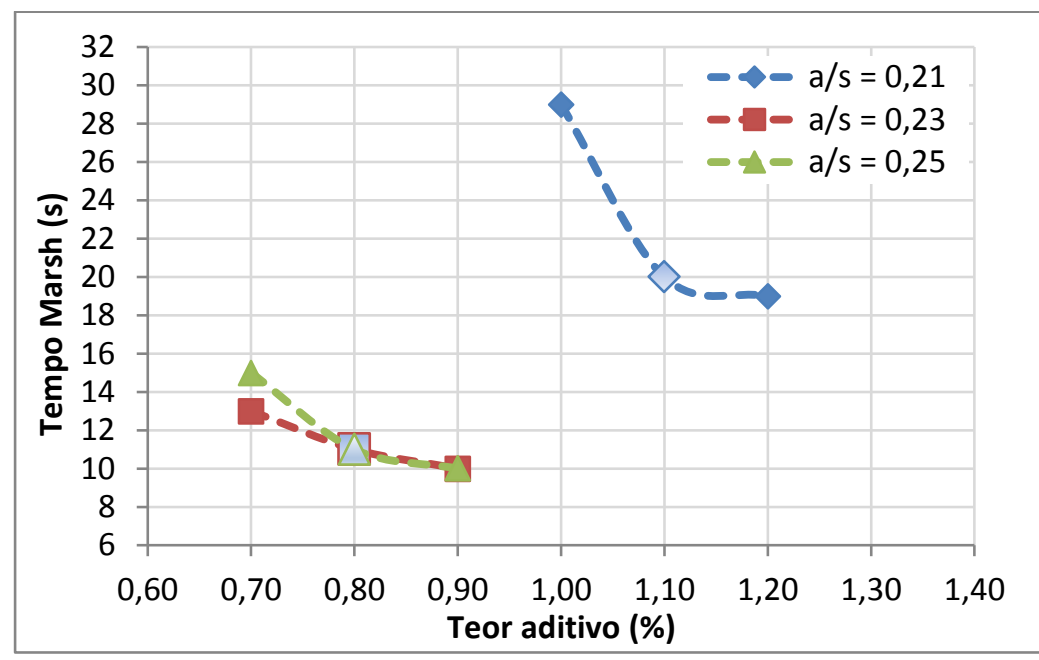

Segundo o gráfico acima, os teores ótimos de aditivo para as pastas x tempo, foram: 1) $1,10 \%$ para a pasta com fator a/s 0,21, com 20 s de escoamento, 2) $0,80 \%$ para a pasta com fator a/s 0,23, com 11s de escoamento, 3) 0,80\% para a pasta com fator a/s 0,25, com $11 \mathrm{~s}$ de escoamento. Observa-se que a pasta com menor teor de água $(0,21)$ apresentou maior viscosidade, necessitando de maiores quantidades de aditivo e de tempo superior para escoar. As demais pastas apresentaram comportamentos de viscosidade semelhantes, atingindo o mesmo ponto de saturação de dispersante e tempo de escoamento.

Observação: embora tenha ocorrido uma diminuição do tempo após atingido o ponto de saturação, tempos de até $2 \mathrm{~s}$ de diferença foram considerados irrelevantes para diminuição da viscosidade. 
A seguir, a Figura 55 mostra o gráfico comparativo entre os teores de aditivo adicionados e os diâmetros de espalhamento atingidos pelo ensaio de minicone.

Figura 55 - Teor de aditivo x Espalhamento para as pastas $40 \%$ quartzo na granulometria SM325

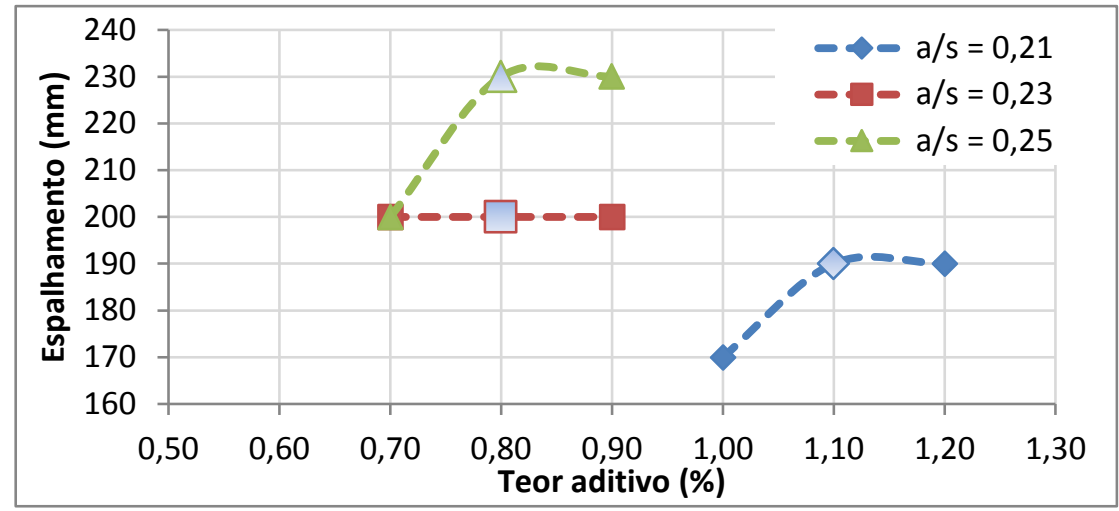

De acordo com o gráfico acima, os espalhamentos atingidos pelas pastas nos teores ótimos de dispersante, foram: 1) 190mm para a pasta com fator a/s 0,21, com teor de aditivo $1,10 \%, 2) 200 \mathrm{~mm}$ para a pasta com fator a/s 0,23 , com teor de aditivo $0,80 \%$, 3) $230 \mathrm{~mm}$ para a pasta com fator a/s 0,25 , com teor de aditivo $0,80 \%$. Nota-se que, embora as pastas com teor de água 0,23 e 0,25 apresentem o mesmo comportamento para a viscosidade no ensaio de funil de Mash (teor ótimo e tempo de escoamento semelhantes), os resultados de espalhamento são divergentes. Logo, a pasta com maior teor de água apresenta menor tensão de escoamento que as demais.

Esses resultados comprovam a importância da análise de ambos os parâmetros reológicos (tensão de escoamento e viscosidade), pois pastas com resultados semelhantes em um dado ensaio podem apresentar comportamento diferente em outro. Além disso, é importante salientar que, embora a pasta com teor de água 0,23 tenha se mantido estável no ensaio de espalhamento, os valores do ensaio de Funil de Marsh se estabilizaram com 0,80\% de dispersante, portanto adotou-se esse ponto como teor ótimo.

B) Pastas $60 \%$ Fíler $40 \%$ Cimento

As Figuras 56 e 57, mostram os gráficos comparativos entre os resultados dos ensaios de reologia feitos com 60\% de fíler SM325 nos teores de água indicados. A Figura 56 compara os efeitos dos teores de aditivo adicionados sobre o tempo de escoamento pelo Funil de Marsh, os pontos destacados indicam os teores ótimos de dispersante. 
Figura 56 - Teor de aditivo x Tempo de Marsh para as pastas $60 \%$ quartzo na granulometria SM325

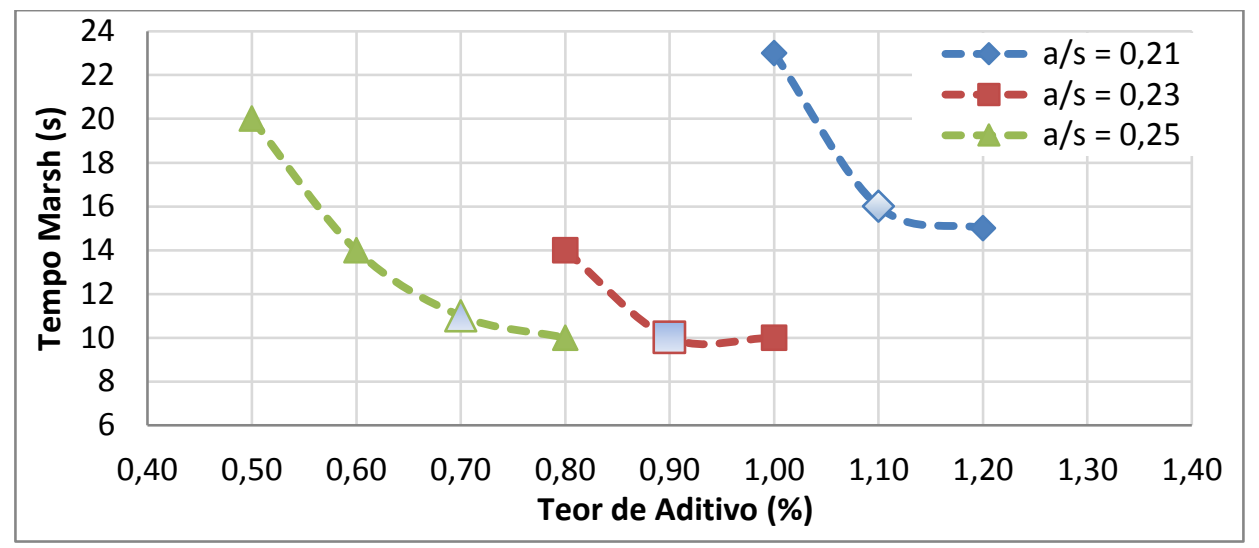

Segundo o gráfico acima, os teores ótimos de aditivo para as pastas $\mathrm{x}$ tempo, foram: 1) $1,10 \%$ para a pasta com fator a/s 0,21, com 16 s de escoamento, 2) $0,90 \%$ para a pasta com fator a/s 0,23, com 10s de escoamento, 3) $0,70 \%$ para a pasta com fator a/s 0,25 , com 11 s de escoamento. Nota-se que a pasta com menor teor de água $(0,21)$ apresentou maior viscosidade que as demais, necessitando de maiores quantidades de aditivo e maior tempo de escoamento. As pastas 0,23 e 0,25 apresentaram viscosidades semelhantes, porém a pasta com maior teor de água necessitou de menos aditivo.

Observação: embora tenha ocorrido diminuição do tempo após atingido o ponto de saturação (curva 0,25 e 0,21), tempos de até 2 s de diferença foram considerados irrelevantes para diminuição da viscosidade.

A seguir, a Figura 57 mostra o comparativo entre o aumento do teor de aditivo e os espalhamentos das pastas no ensaio de minicone.

Figura 57 - Teor de aditivo x Espalhamento para as pastas $60 \%$ quartzo na granulometria SM325

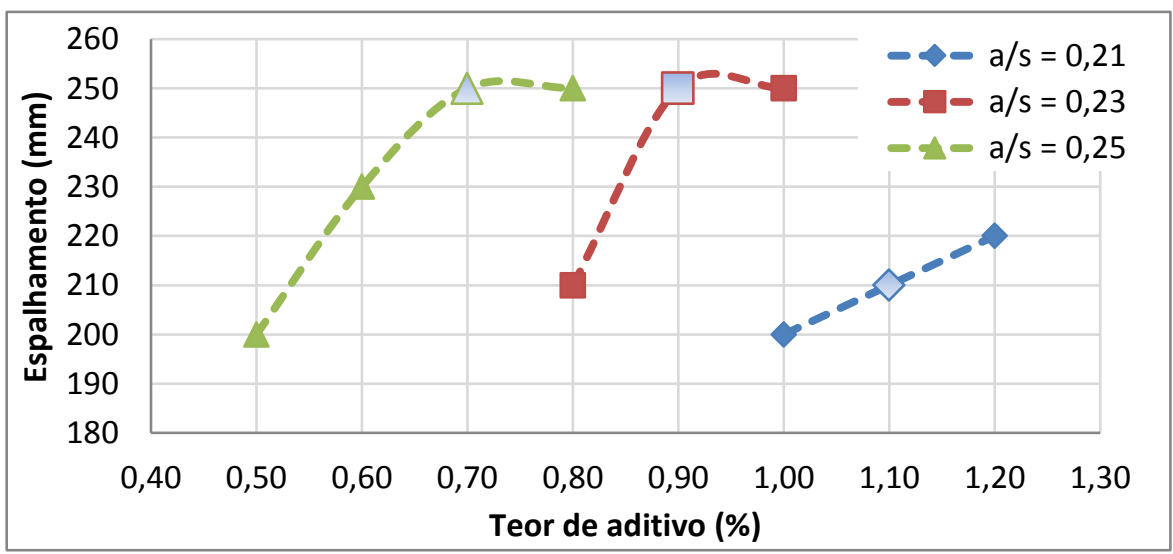

De acordo com o gráfico acima, os espalhamentos atingidos pelas pastas nos teores ótimos de dispersante, foram: 1) 210mm para a pasta com fator a/s 0,21, com teor de aditivo 
$1,10 \%$, 2) $250 \mathrm{~mm}$ para a pasta com fator a/s 0,23 , com teor de aditivo $0,90 \%$, 3) $250 \mathrm{~mm}$ para a pasta com fator a/s 0,25 , com teor de aditivo $0,70 \%$. Nota-se que a pasta com menor teor de água atingiu um espalhamento inferior às demais, indicando maior tensão de escoamento. Ainda, para a pasta 0,21, embora a curva de espalhamento tenha aumentado após o ponto de saturação de aditivo, a variação de $10 \mathrm{~mm}$ foi considerada pouco significativa e os valores de Funil de Marsh já haviam estabilizado para este ponto. As pastas 0,23 e 0,25 apresentaram o mesmo comportamento para ambos os parâmetros (viscosidade e tensão de escoamento), pois ambas atingiram o mesmo diâmetro de espalhamento e tempos semelhantes de escoamento no ponto ótimo de dispersante.

\subsubsection{Fíler SM400}

\section{A) Pastas $40 \%$ Fíler $60 \%$ Cimento}

As Figuras 58 e 59 mostram os gráficos comparativos entre os resultados dos ensaios reológicos feitos com $40 \%$ de fíler SM400 nos teores de água indicados. A Figura 58 compara os efeitos do aumento dos teores de aditivo adicionados sobre o tempo de escoamento pelo Funil de Marsh, os pontos destacados indicam os teores ótimos de dispersante.

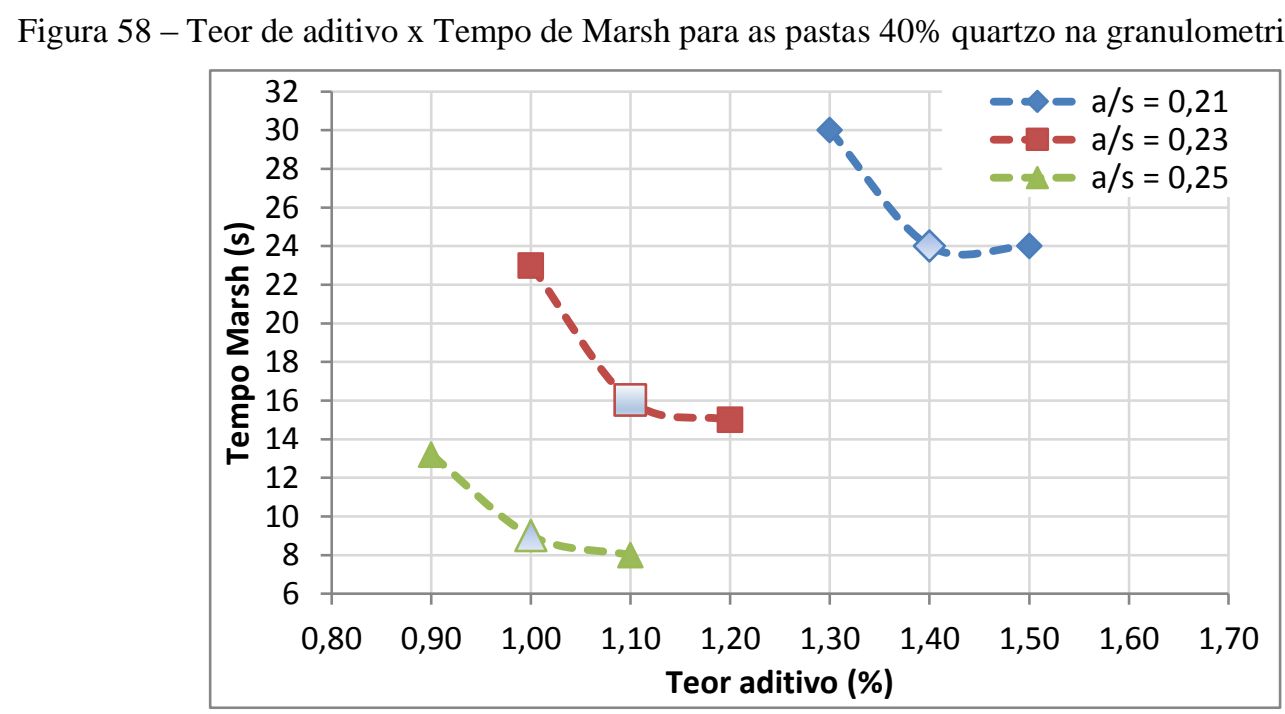

De acordo com o gráfico acima, os teores ótimos de aditivo para as pastas $\mathrm{x}$ tempo, foram: 1) 1,40\% para a pasta com fator a/s 0,21 , com 24 s de escoamento, 2) 1,10\% para a pasta com fator a/s 0,23, com 16 s de escoamento, 3) 1,00\% para a pasta com fator a/s 0,25, com 9s de escoamento. Nota-se que a pasta com menor teor de água apresentou maior viscosidade que as demais, necessitando de maior teor de aditivo e mais tempo de escoamento. A pasta com maior teor de água exigiu menores quantidades de dispersante e menor tempo de escoamento, 
manifestando menor viscosidade. Em relação à curva 0,23 , a queda de 16 s para 15 s no ponto ótimo de dispersante não foi considerada significativa para escolha do terceiro ponto de aditivo, pois não influencia na viscosidade da suspensão.

A Figura 59 mostra a relação entre os teores de aditivo e os espalhamentos das pastas pelo minicone.

Figura 59 - Teor de aditivo x Espalhamento para as pastas $40 \%$ quartzo na granulometria SM400

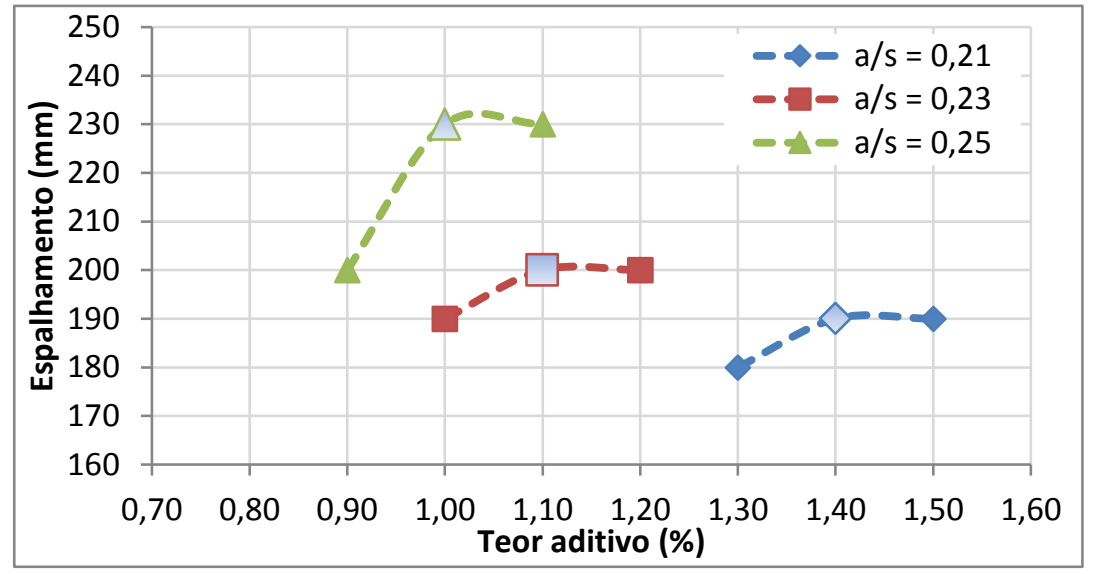

De acordo com o gráfico acima, os espalhamentos atingidos pelas pastas nos teores ótimos de dispersante, foram: 1) 190mm para a pasta com fator a/s 0,21, com teor de aditivo $1,40 \%$, 2) $200 \mathrm{~mm}$ para a pasta com fator a/s 0,23 , com teor de aditivo $1,10 \%$, 3) 230mm para a pasta com fator a/s 0,25, com teor de aditivo 1,00\%. Logo, observa-se que a pasta com teor de água 0,21 apresentou maior tensão de escoamento que as demais, pois atingiu um espalhamento inferior (190mm) e exigiu maiores adições de dispersante. A pasta com maior teor de água, exibiu menor tensão de escoamento, pois alcançou um espalhamento superior $(230 \mathrm{~mm})$ com menor teor de dispersante.

B) Pastas $60 \%$ Fíler $40 \%$ Cimento

As Figuras 60 e 61, mostram os gráficos comparativos entre os resultados dos ensaios de reologia feitos com $60 \%$ de fíler SM400 nos teores de água indicados. Abaixo, a Figura 60 compara os efeitos dos teores de aditivo adicionados sobre o tempo de escoamento pelo Funil de Marsh, os pontos em destaque indicam os teores ótimos de dispersante. 
Figura 60 - Teor de aditivo x Tempo de Marsh para as pastas 60\% quartzo na granulometria SM400

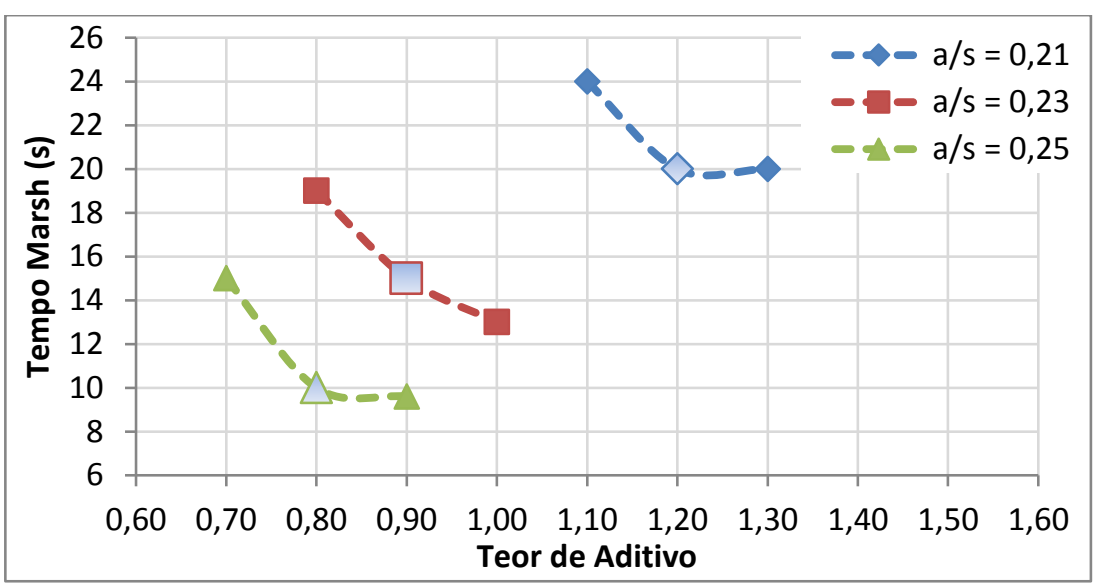

De acordo com o gráfico acima, os teores ótimos de aditivo para as pastas $\mathrm{x}$ tempo, foram: 1) $1,20 \%$ para a pasta com fator a/s 0,21 , com 20 s de escoamento, 2) $0,90 \%$ para a pasta com fator a/s 0,23 , com $15 \mathrm{~s}$ de escoamento, 3) $0,80 \%$ para a pasta com fator a/s 0,25 , com $10 \mathrm{~s}$ de escoamento. Os resultados mostram que a pasta com menor teor de água apresentou maior viscosidade que as demais, pois necessitou de maior teor de dispersante e tempo superior para escoar pelo funil. A pasta com maior teor de água, apresentou menor viscosidade, pois exigiu menores quantidades de aditivo e menor tempo de escoamento. Nota-se que, na pasta 0,23, houve uma diminuição do tempo de $15 \mathrm{~s}$ para $13 \mathrm{~s}$, porém variações de até $2 \mathrm{~s}$ foram consideradas não significativas para influencia na viscosidade da suspensão. Além disso, os valores de espalhamento no ensaio de minicone foram estabilizados no ponto ótimo escolhido (Figura 61).

A Figura 61 mostra os comparativos entre o aumento no teor de aditivo e os espalhamentos das pastas no ensaio de minicone.

Figura 61 - Teor de aditivo x Espalhamento para as pastas 60\% quartzo na granulometria SM400

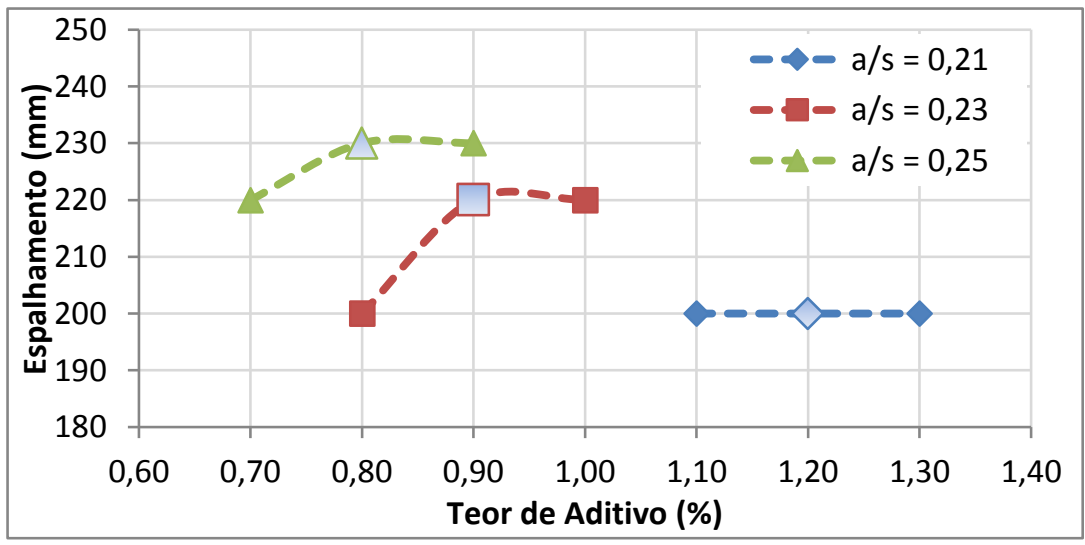

De acordo com o gráfico acima, os espalhamentos atingidos pelas pastas nos teores ótimos de dispersante, foram: 1) 200mm para a pasta com fator a/s 0,21 , com teor de aditivo 
$1,20 \%, 2) 220 \mathrm{~mm}$ para a pasta com fator a/s 0,23 , com teor de aditivo $0,90 \%$, 3) 230mm para a pasta com fator a/s 0,25 , com teor de aditivo $0,80 \%$. A pasta com menor teor de água $(0,21)$ manifestou um comportamento estável de espalhamento desde o teor inicial de dispersante, porém os valores de Funil de Marsh só se estabilizaram a partir do ponto de saturação de aditivo escolhido, sendo o parâmetro mais importante para a determinação. A pasta com maior teor de água exibiu menor tensão de escoamento que as demais, atingindo um espalhamento superior com menor teor de dispersante.

\subsubsection{Comparativos entre os resultados}

A partir dos dados obtidos, foram elaborados gráficos comparativos entre os comportamentos reológicos das pastas de cimento puro e das misturas com substituição de $40 \%$ e $60 \%$ de fíler, para os teores de água (fator a/s) 0,21-0,23-0,25.

\subsubsection{Fator a/s 0,21}

A Figura 62 mostra os gráficos comparativos entre os comportamentos reológicos das suspensões verificados nos ensaios de espalhamento pelo minicone, conforme o aumento do teor de aditivo para o teor de água 0,21. Os pontos em destaque indicam as dosagens ótimas de dispersante.

Figura 62 - Comparativos entre Teor de aditivo x Espalhamento das pastas no fator a/s 0,21

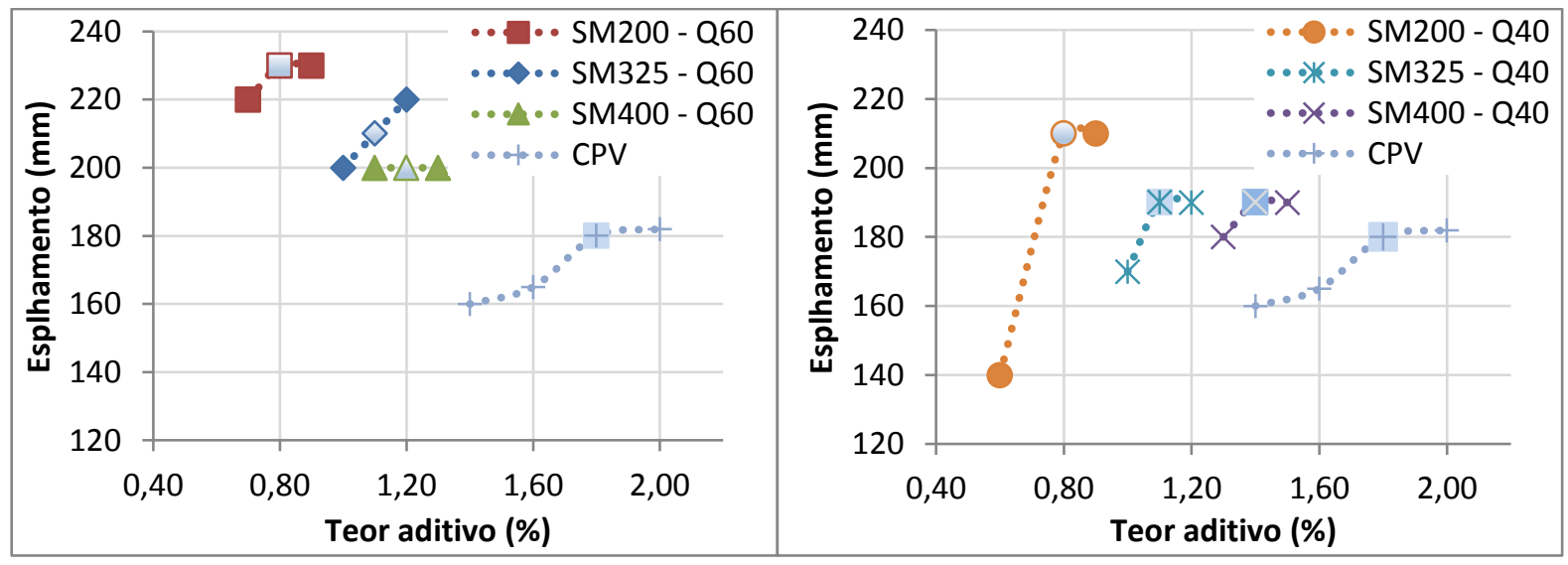

Segundo o gráfico acima, os diâmetros de espalhamento atingidos pelas pastas para os teores ótimos de aditivo, foram:

1) $230 \mathrm{~mm}$ para a pasta com $60 \%$ de fíler SM200, com teor de aditivo $0,80 \%$, enquanto a mistura com $40 \%$ de fíler atingiu $210 \mathrm{~mm}$ com o mesmo teor de dispersante; 
2) $210 \mathrm{~mm}$ para a pasta com $60 \%$ de fíler SM325, com teor de aditivo $1,10 \%$, enquanto a mistura com $40 \%$ de fíler atingiu 190mm com o mesmo teor de dispersante;

3) $200 \mathrm{~mm}$ para a pasta com $60 \%$ de fíler SM400, com teor de aditivo $1,20 \%$, enquanto a mistura com $40 \%$ de fíler atingiu $190 \mathrm{~mm}$ com teor de aditivo $1,40 \%$;

4) $180 \mathrm{~mm}$ para a pasta de CPV, com teor de aditivo $1,80 \%$.

Nota-se que a pasta de CPV apresentou maior tensão de escoamento que as pastas com fíleres, pois atingiu um espalhamento inferior, exigindo maiores quantidades de dispersante. Esse fator mostra que há uma melhoria na reologia das pastas proporcionada pelo uso dos fíleres. É importante ressaltar que, em geral, se conseguiu maior fluidez nas pastas com $60 \%$ de fíler, quando comparadas às misturas com $40 \%$ para um mesmo fíler. Esses resultados demonstram que a incorporação desses fíleres de quartzo em materiais cimentícios, apresenta potencial para redução de água na obtenção de um mesmo comportamento reológico que o material de cimento puro.

A Figura 63 compara os comportamentos das pastas nos ensaios de Funil de Marsh, conforme a adição de dispersante para o teor de água 0,21 .

Figura 63 - Comparativos entre Teor de aditivo x Tempo de Marsh das pastas no fator a/s 0,21

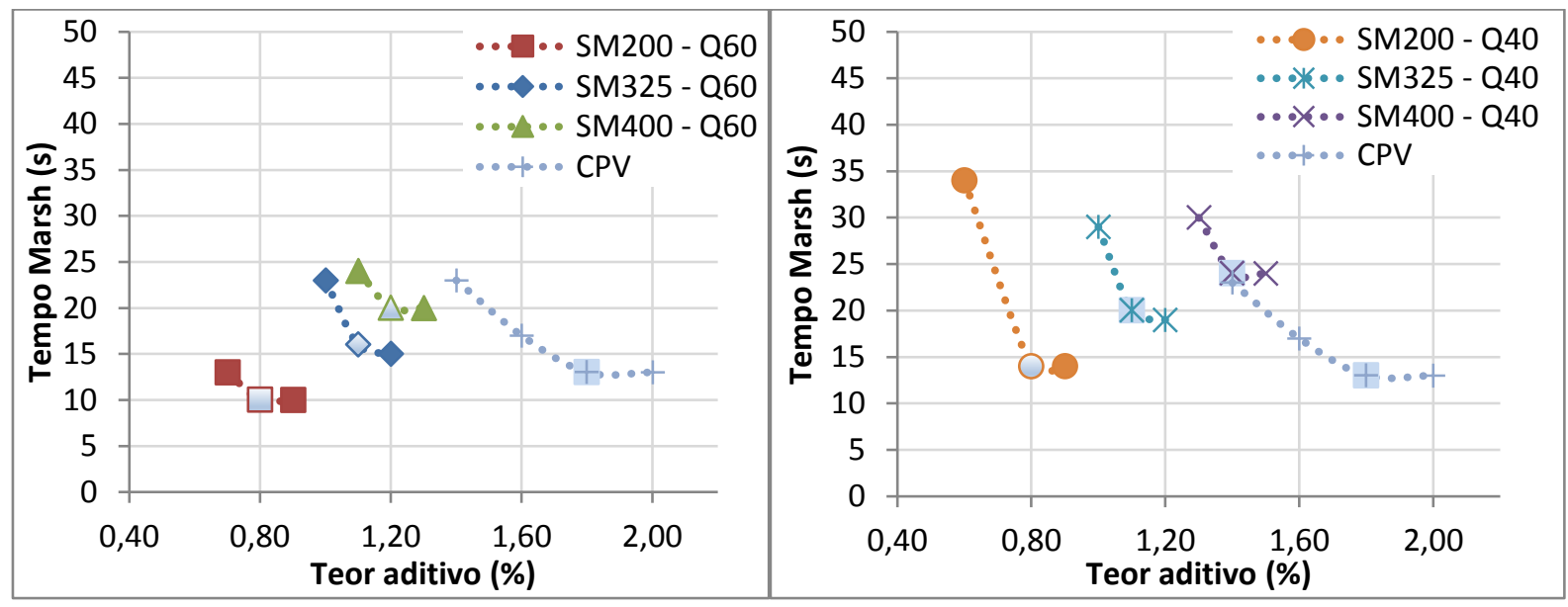

De acordo com o gráfico acima, os tempos de escoamento das pastas pelo Funil de Marsh para os teores ótimos de dispersante, foram:

1) 10 s para a pasta com $60 \%$ de fíler SM200, com teor de aditivo $0,80 \%$, enquanto a mistura com $40 \%$ de fíler teve 14 s de escoamento com o mesmo teor de aditivo;

2) 16s para a pasta com $60 \%$ de fíler SM325, com teor de aditivo $1,10 \%$, enquanto a mistura com $40 \%$ de fíler teve 20 s de escoamento com o mesmo teor de aditivo; 
3) 20s para a pasta com $60 \%$ de fíler SM400, com teor de aditivo $1,20 \%$, enquanto a mistura com $40 \%$ de fíler teve 24 s de escoamento com $1,40 \%$ de aditivo;

4) $13 \mathrm{~s}$ para a pasta de CPV, com teor de aditivo $1,80 \%$.

Pode-se observar que o fíler SM400 levou mais tempo de escoamento que as demais misturas feitas com fíleres de quartzo, fator que pode estar relacionado à sua granulometria mais fina, que provoca um aumento na viscosidade da suspensão. Os comportamentos das pastas para esse parâmetro reológico, mostraram que, comparando as pastas de mesmo fíler, as dosagens feitas com maior teor de fíler (60\%) atingiram maior fluidez. Além disso, as misturas feitas com fíleres atingiram um patamar de viscosidade semelhante ao do cimento, com tempos próximos de escoamento. Esses dados evidenciam que é possível produzir materiais cimentícios por meio da substituição de parte do cimento por fíleres de quartzo, promovendo a mesma fluidez com o mesmo teor de água que o material convencional.

\subsubsection{Fator a/s 0,23}

A Figura 64 compara os comportamentos reológicos das suspensões verificados nos ensaios de espalhamento pelo minicone, conforme o aumento do teor de dispersante para o teor de água 0,23 .

Figura 64 - Comparativos entre Teor de aditivo x Espalhamento das pastas no fator a/s 0,23

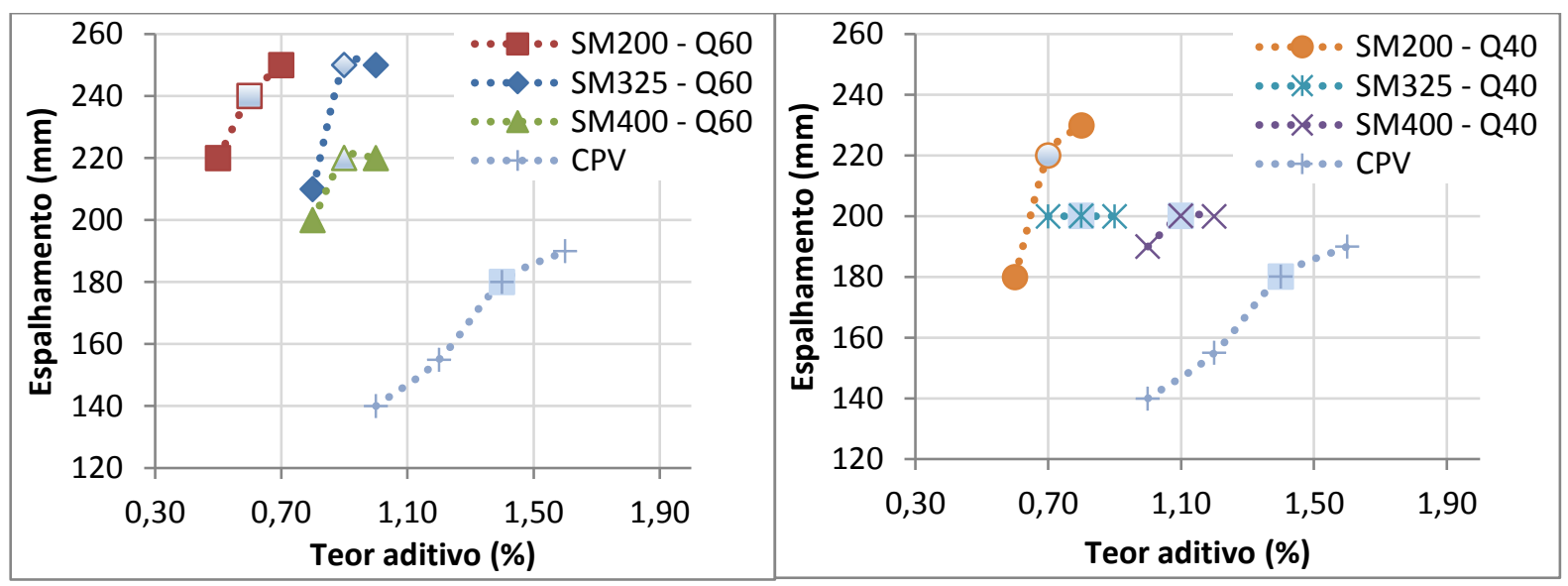

De acordo com o gráfico acima, os espalhamentos atingidos pelas pastas para os teores ótimos de dispersante, foram:

1) $240 \mathrm{~mm}$ para a pasta com $60 \%$ de fíler SM200, com teor de aditivo $0,60 \%$, enquanto a mistura com $40 \%$ de fíler atingiu $220 \mathrm{~mm}$ com teor de aditivo $0,70 \%$;

2) $250 \mathrm{~mm}$ para a pasta com $60 \%$ de fíler SM325, com teor de aditivo $0,90 \%$, enquanto a mistura com $40 \%$ atingiu $200 \mathrm{~mm}$ com $0,80 \%$ de aditivo; 
3) $220 \mathrm{~mm}$ para a pasta com $60 \%$ de fíler SM400, com teor de aditivo $0,90 \%$, enquanto a mistura com $40 \%$ atingiu $200 \mathrm{~mm}$ com $1,10 \%$ de aditivo;

4) $180 \mathrm{~mm}$ para a pasta de CPV, com $1,40 \%$ de aditivo.

Para as misturas com teor de água 0,23, observa-se que as dosagens com $60 \%$ de fíler apresentaram menores tensões de escoamento que as com $40 \%$ de fíler (comparando fíleres de mesma granulometria). Os resultados comprovam que, para esse teor de água, a incorporação de fíleres nas misturas, também proporcionaram melhorias nos comportamentos reológicos, pois a pasta de cimento apresentou maior tensão de escoamento, atingindo um espalhamento inferior com maiores quantidades de aditivo.

A Figura 65 compara os comportamentos das pastas nos ensaios de Funil de Marsh, conforme a adição de dispersante para o teor de água 0,23.

Figura 65 - Comparativos entre Teor de aditivo x Tempo de Marsh das pastas no fator a/s 0,23

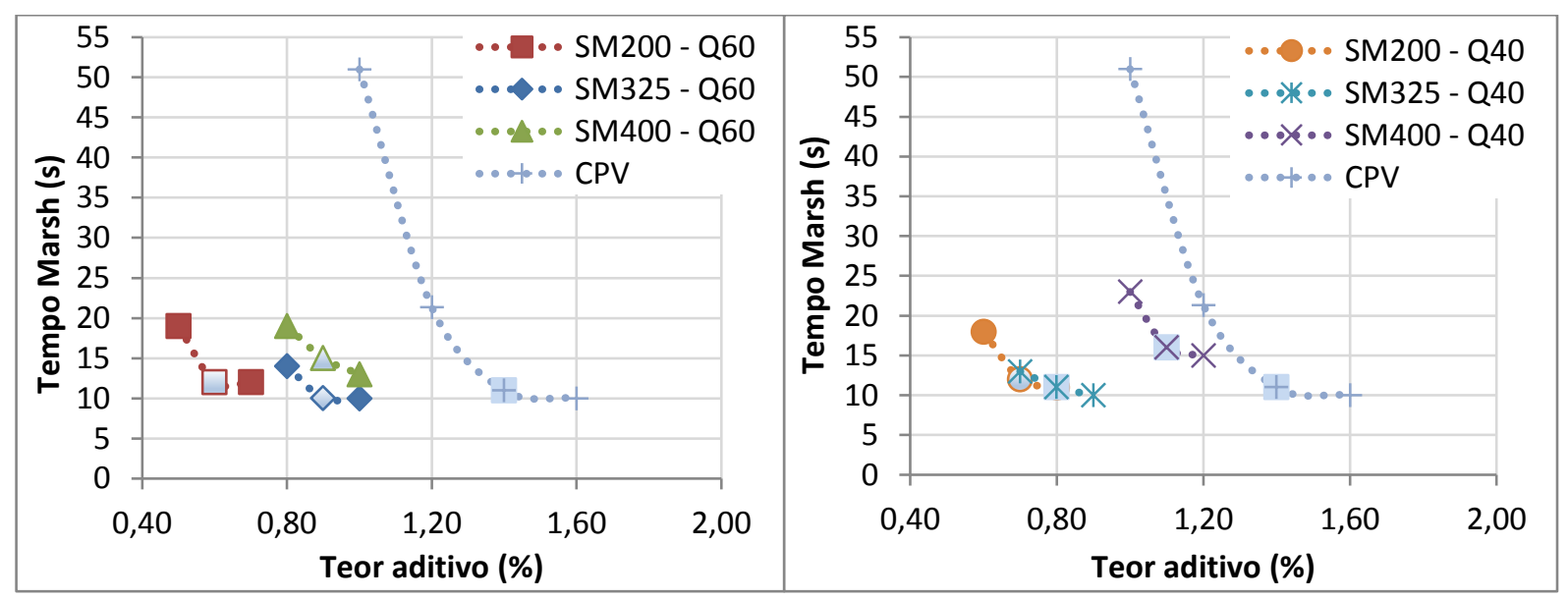

De acordo com o gráfico acima, os tempos de escoamento das pastas pelo Funil de Marsh para os teores ótimos de aditivo, foram:

1) $12 \mathrm{~s}$ para a pasta com $60 \%$ de fíler SM200, com teor de aditivo $0,60 \%$, enquanto a mistura com $40 \%$ também teve $12 \mathrm{~s}$ de escoamento, porém com teor de aditivo $0,70 \%$;

2) 10s para a pasta com $60 \%$ de fíler SM325, com teor de aditivo $0,90 \%$, enquanto a mistura com $40 \%$ teve $11 \mathrm{~s}$ de escoamento com $0,80 \%$ de aditivo;

3) $15 \mathrm{~s}$ para a pasta com $60 \%$ de fíler SM400, com teor de aditivo $0,90 \%$, enquanto a mistura com $40 \%$ teve 16 s de escoamento com $1,10 \%$ de aditivo;

4) 11s para a pasta de CPV, com teor de aditivo $1,40 \%$. 
Os resultados para avaliação da viscosidade, mostram que a maioria das pastas apresentaram comportamentos semelhantes. Entre as misturas com fíleres, as pastas de SM400, com granulometria mais fina, demonstraram maiores viscosidades que as demais, levando tempos superiores para escoar pelo funil, porém exigiram menores teores de aditivo que a pasta de cimento. Embora a pasta de CPV tenha obtido um tempo de escoamento próximo às misturas com fíleres, exigiu maiores quantidades de dispersante para fluir, comprovando que os fíleres também propiciaram uma melhoria para esse parâmetro reológico.

\subsubsection{Fator a/s 0,25}

A Figura 66 compara os comportamentos das suspensões nos ensaios de espalhamento pelo minicone, conforme a adição de dispersante para o teor de água 0,25.

Figura 66 - Comparativos do Teor de aditivo x Espalhamento das pastas no fator a/s 0,25

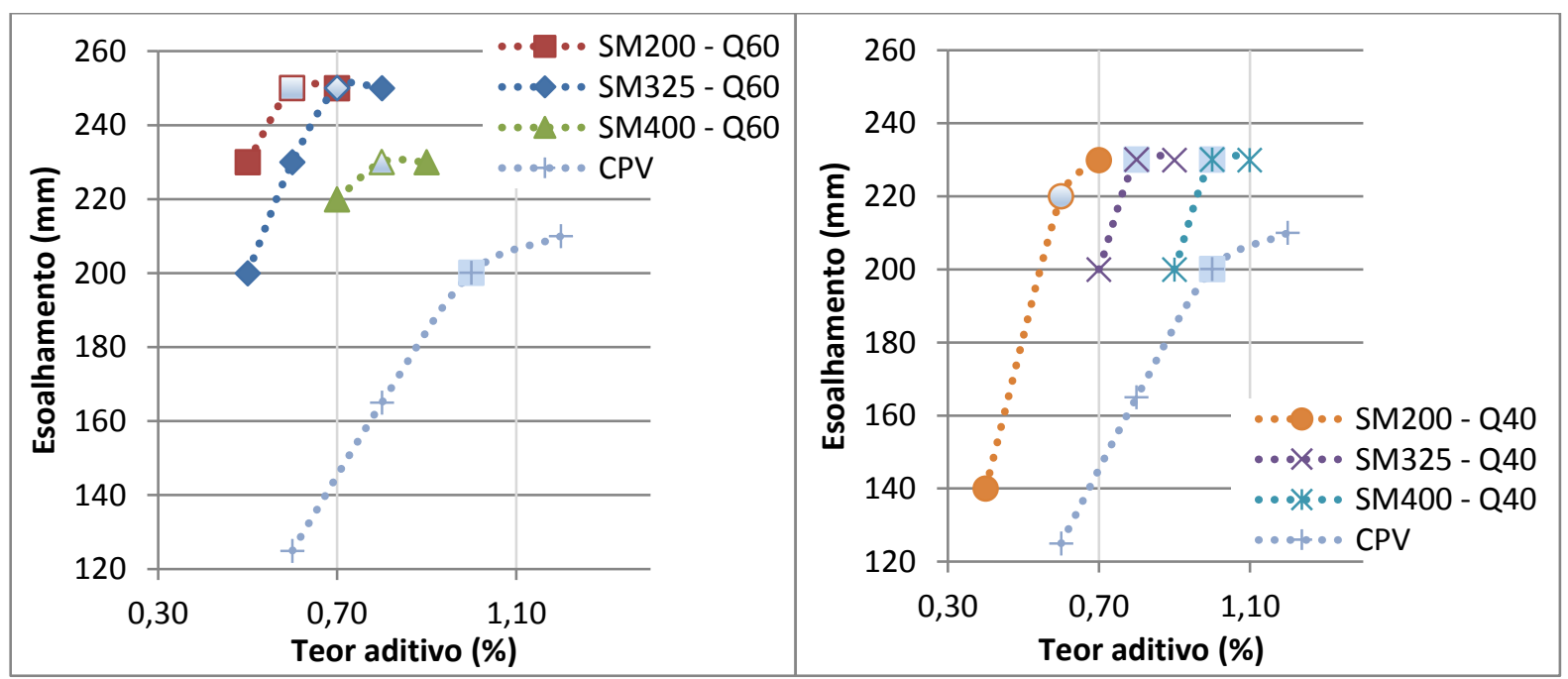

De acordo com o gráfico acima, os espalhamentos atingidos pelas pastas nos teores ótimos de dispersante, foram:

1) $250 \mathrm{~mm}$ para a pasta com $60 \%$ de fíler SM200, com teor de aditivo $0,60 \%$, enquanto a mistura com $40 \%$ atingiu $220 \mathrm{~mm}$ de espalhamento com $0,60 \%$ de aditivo;

2) $250 \mathrm{~mm}$ para a pasta com $60 \%$ de fíler SM325, com teor de aditivo $0,70 \%$, enquanto a mistura com $40 \%$ atingiu $230 \mathrm{~mm}$ de espalhamento com $0,80 \%$ de aditivo;

3) $230 \mathrm{~mm}$ para a pasta com $60 \%$ de fíler SM400, com teor de aditivo $0,80 \%$, enquanto a mistura com $40 \%$ obteve o mesmo espalhamento com 1,00\% de aditivo;

4) $200 \mathrm{~mm}$ para a pasta de CPV, com teor de aditivo $1,00 \%$.

Para cada granulometria de finos, nota-se que as misturas com $60 \%$ de fíler atingiram espalhamentos superiores às dosagens com $40 \%$, mesmo com teores ótimos de dispersante 
equivalentes (caso dos fíleres SM200 e SM325). Para as pastas de SM400, a mistura com 40\% de fíler necessitou de maior teor de aditivo para atingir o mesmo espalhamento que a pasta com $60 \%$ de fíler. Os resultados dos ensaios para tensão de escoamento mostram que, para o teor de água 0,25 , as pastas com fíleres também apresentaram comportamento reológico melhor que a pasta de CPV.

A Figura 67 compara os comportamentos das pastas nos ensaios de Funil de Marsh, conforme a adição de dispersante para o teor de água 0,25.

Figura 67 - Comparativos entre Teor de aditivo x Tempo de Marsh das pastas no fator a/s 0,25

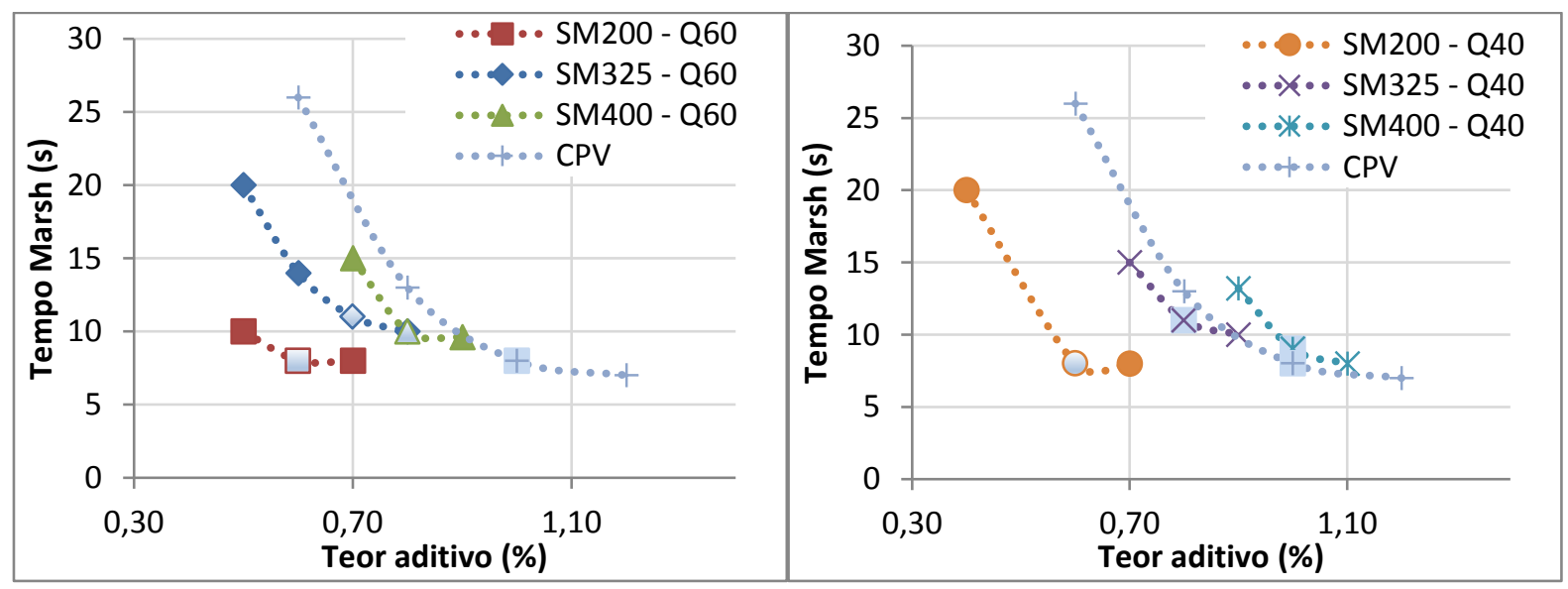

De acordo com o gráfico acima, os tempos de escoamento das pastas pelo Funil de Marsh para os teores ótimos de dispersante, foram:

1) 8s para a pasta com $60 \%$ de fíler SM200, com teor de aditivo 0,60\%, enquanto a mistura com $40 \%$ levou o mesmo tempo com o mesmo teor de dispersante;

2) $11 \mathrm{~s}$ para a pasta com $60 \%$ de fíler SM325, com teor de aditivo $0,70 \%$, enquanto a mistura com $40 \%$ levou o mesmo tempo, porém com $0,80 \%$ de aditivo;

3) 10 s para a pasta com $60 \%$ de fíler SM400, com teor de aditivo $0,80 \%$, enquanto a mistura com $40 \%$ teve 9 s de escoamento com $1,00 \%$ de aditivo;

4) 8s para a pasta de CPV, com $1,00 \%$ de aditivo.

Observa-se que as misturas com o fíler SM200, de granulometria mais grossa, demandaram menor teor de aditivo para fluir. Entretanto, as pastas apresentaram pouca diferença significativa no tempo de escoamento pelo Funil de Marsh, mesmo para a mistura de CPV. Esse fenômeno pode ter ocorrido, devido ao aumento do teor de água na suspensão, que mantém as partículas afastadas, de modo que o dispersante não proporciona interferência significativa na diminuição da viscosidade. 


\subsubsection{Reprodutibilidade e Desvio Padrão}

Os ensaios de reologia para os parâmetros de viscosidade e tensão de escoamento, juntamente com a determinação do teor ótimo de dispersante foram repetidos três vezes, a fim de verificar a proximidade e o desvio padrão entre os resultados. Foram feitos comparativos entre os ensaios com as pastas de cimento CPV, cimento-fíler com SM200 e cimento-fíler com SM400 nas dosagens de 40\% e 60\%, para os teores de água (fator a/s) 0,21 e 0,25.

\subsubsection{Pastas de CPV}

As Figuras 68 e 69 mostram os resultados dos três ensaios de espalhamento pelo minicone e Funil de Marsh, respectivamente, das pastas de cimento com teor de água 0,21.

Figura 68 - Reprodutibilidade do espalhamento das pastas de CPV, fator a/s 0,21

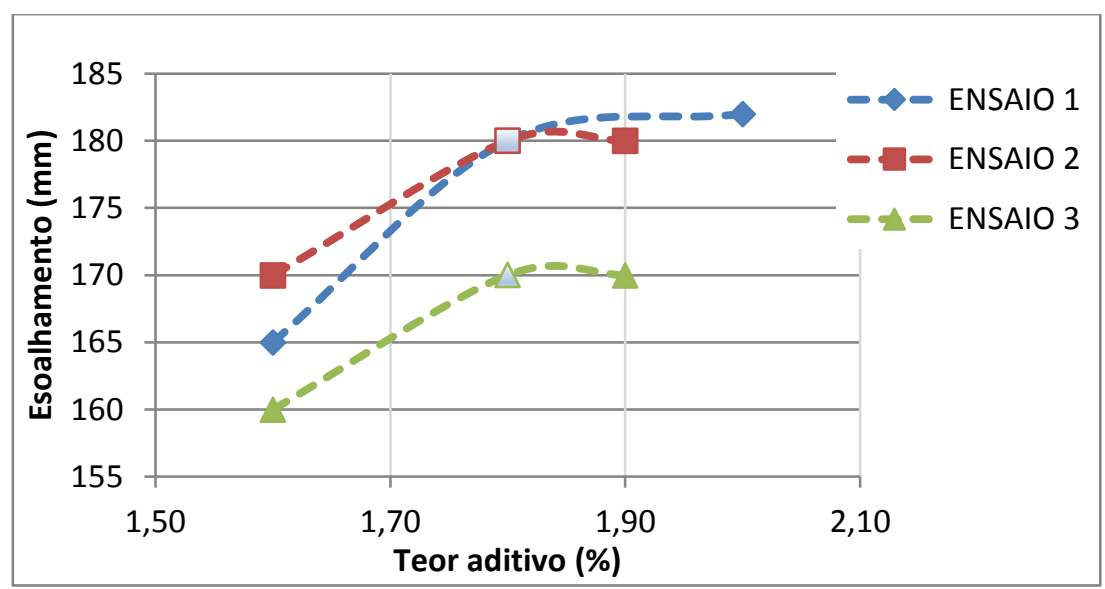

Figura 69 - Reprodutibilidade do Funil de Marsh das pastas de CPV, fator a/s 0,21

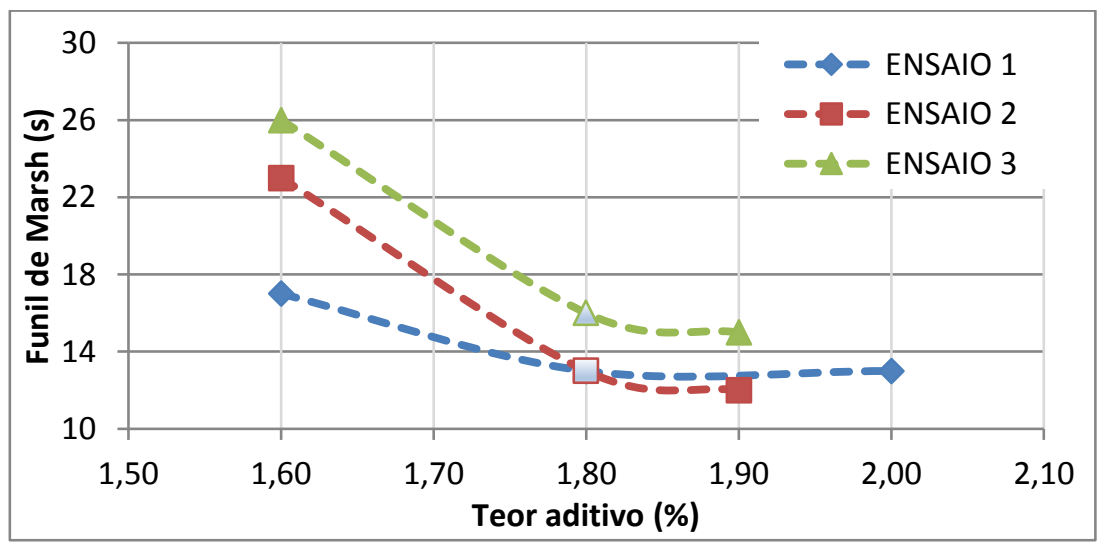


Os pontos em destaque nos gráficos mostram que o teor ideal de dispersante determinado foi o mesmo para os três ensaios, havendo proximidade entre os espalhamentos e pouca variabilidade entre os resultados (até 10mm). Para o Funil de Marsh, os ensaios 1 e 2 apresentaram viscosidades semelhantes, com tempos de escoamento próximos. A pasta do terceiro ensaio apresentou maior viscosidade e maior tensão de escoamento, que pode ter sido influenciada pela umidade e clima do ambiente, ou pelo tempo de execução dos ensaios.

As Figuras 70 e 71 mostram os comparativos entre os comportamentos reológicos dos três ensaios com pastas de CPV para o teor de água 0,25.

Figura 70 - Reprodutibilidade do espalhamento das pastas de CPV, fator a/s 0,25

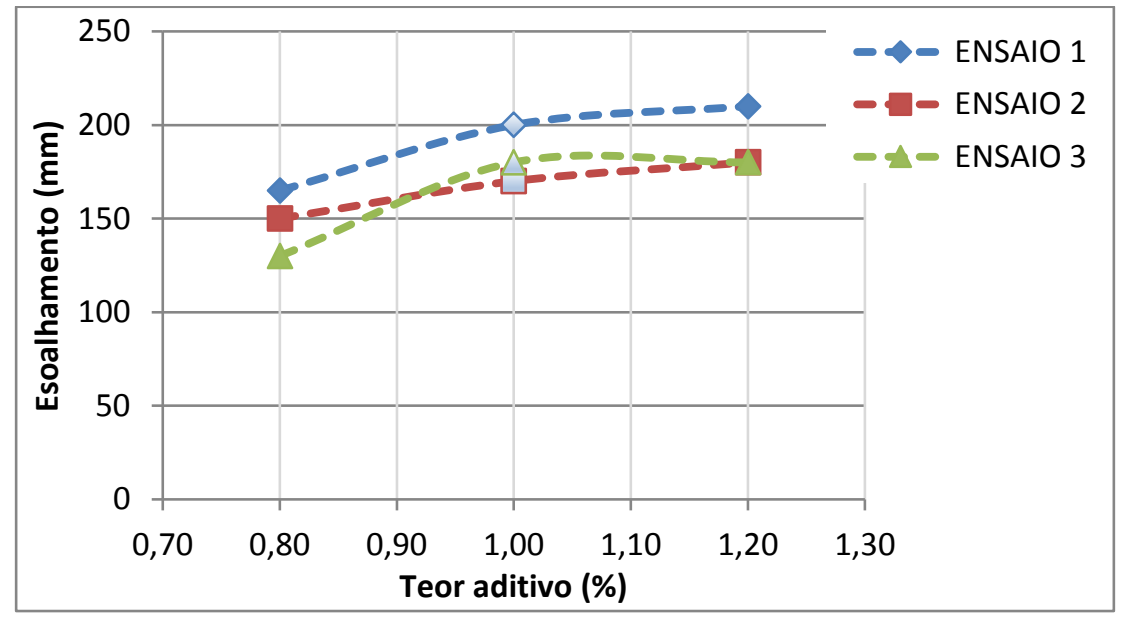

Figura 71 - Reprodutibilidade do Funil de Marsh das pastas de CPV, fator a/s 0,25

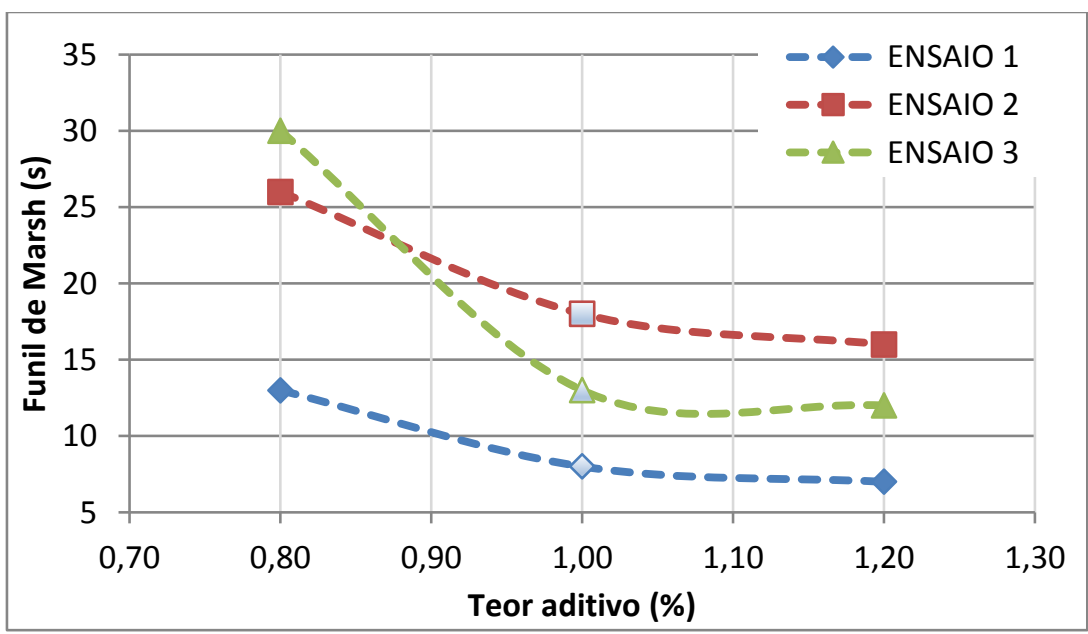

O gráfico da Figura 70 mostra que as pastas apresentaram tensões de escoamento semelhantes nos três ensaios, atingindo espalhamentos próximos e o mesmo teor ideal de dispersante. Entretanto, apresentaram viscosidades diferentes, provavelmente por influências ambientais e do tempo de execução dos ensaios. 


\subsubsection{Pastas com SM200}

A seguir, os gráficos das Figuras 72 e 73 comparam os comportamentos reológicos das pastas de cimento-fíler SM200 para o teor de água 0,21, nas substituições de $60 \%$ e $40 \%$ de quartzo sobre o volume de cimento.

Figura 72 - Reprodutibilidade do espalhamento das pastas de SM200, fator a/s 0,21

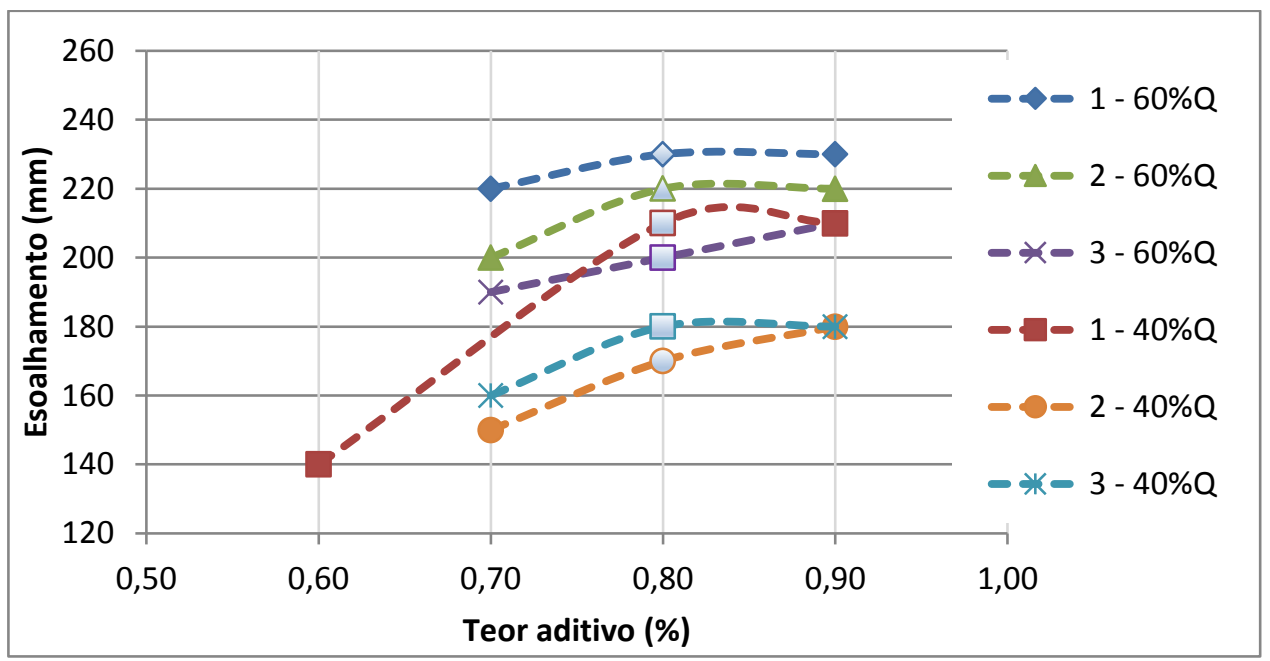

Figura 73 - Reprodutibilidade do Funil de Marsh das pastas de SM200, fator a/s 0,21

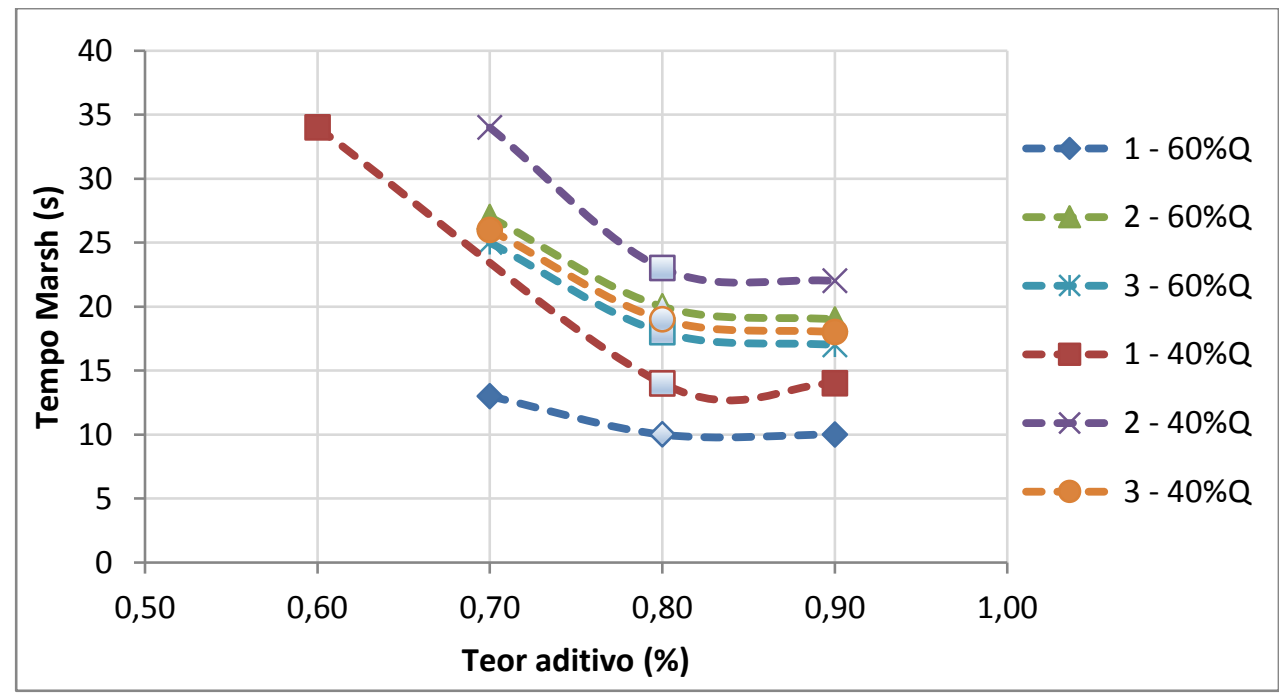

De acordo com o gráfico da Figura 72, os ensaios 1 e 2 para as pastas com $60 \%$ de fíler atingiram espalhamentos próximos, já no Funil de Marsh (Figura 73), os ensaios 2 e 3 para essa mesma dosagem, apresentaram viscosidades equivalentes e superiores à pasta do primeiro ensaio. As pastas com 40\% de SM200 apresentaram equivalência de espalhamento nos ensaios 2 e 3 (Figura 72), já para a viscosidade (Figura 73) os comportamentos nos três ensaios foram distintos. Os teores ótimos de dispersante foram os mesmos em todas as repetições. 
As Figuras 74 e 75 mostram os comparativos entre as repetições dos ensaios de espalhamento e Funil de Marsh para as pastas de cimento-fíler SM200 com teor de água 0,25.

Figura 74 - Reprodutibilidade do espalhamento das pastas de SM200, fator a/s 0,25

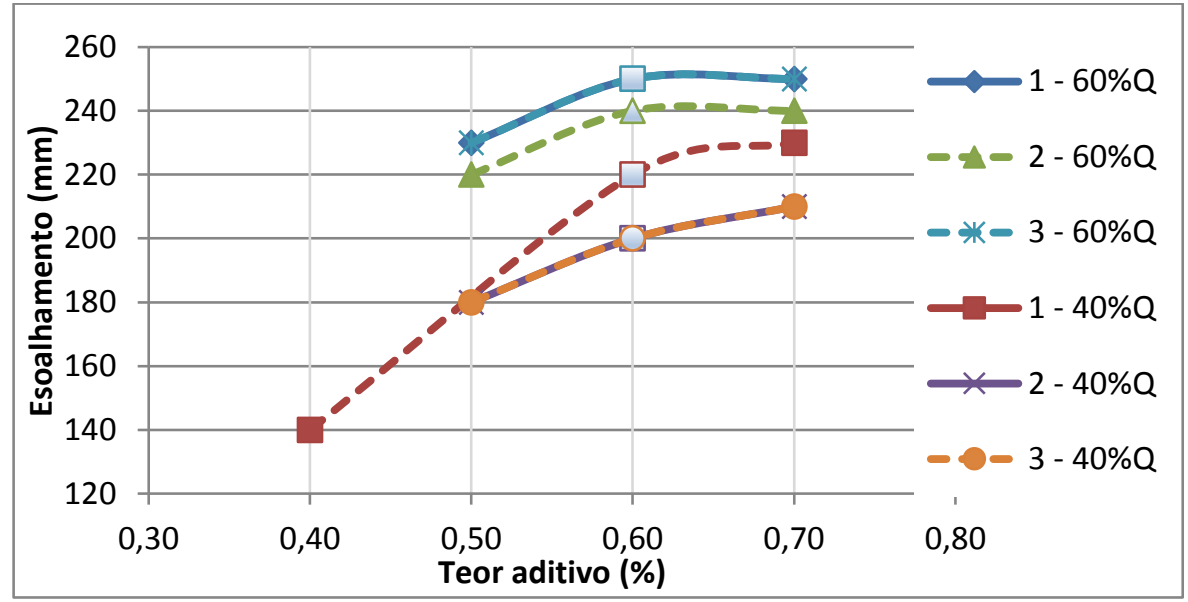

Figura 75 - Reprodutibilidade do Funil de Marsh das pastas de SM200, fator a/s 0,25

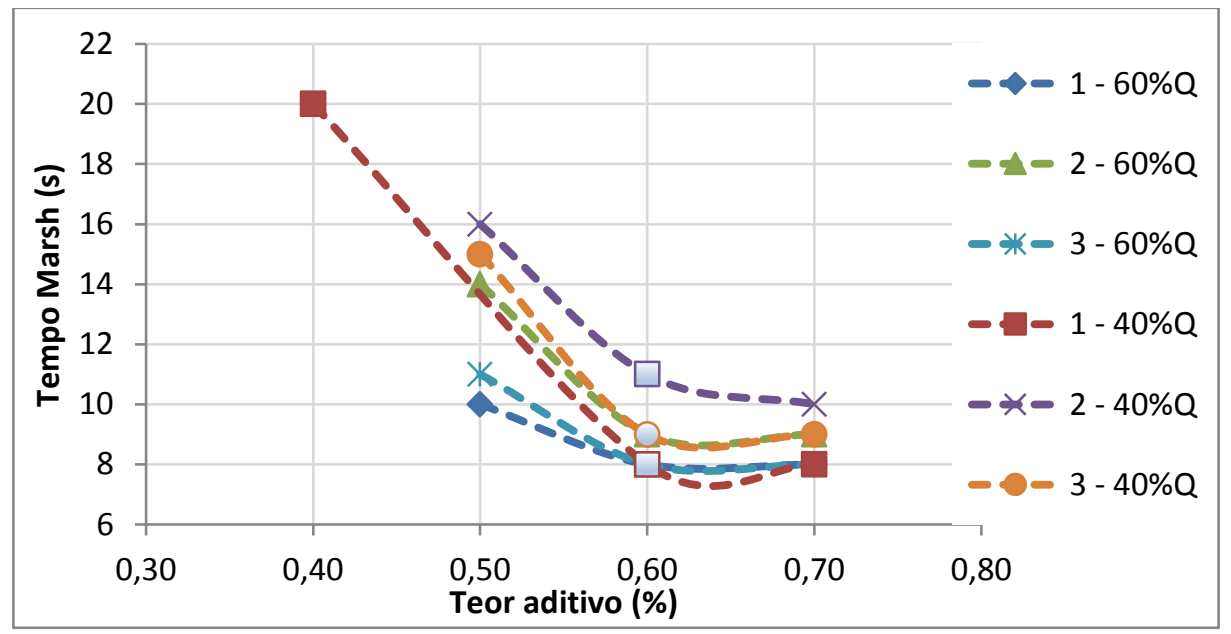

De acordo com os gráficos acima, observa-se que os ensaios 1, 2 e 3 com as pastas com $60 \%$ de fíler atingiram os mesmos comportamentos reológicos nos ensaios de espalhamento pelo minicone e Funil de Marsh, Figuras 74 e 75, respectivamente. As pastas com 40\% de fíler apresentaram espalhamentos equivalentes nos ensaios 2 e 3 (Figura 74), já para o parâmetro de viscosidade as três repetições atingiram comportamentos próximos (Figura 75). Os teores ideiais de dispersante foram iguais em todos os ensaios.

\subsubsection{Pastas com SM400}

As Figuras 76 e 77 mostram os comparativos entre as repetições dos ensaios de reologia das pastas de cimento-fíler SM400 com teor de água 0,21, nas substituições de 40\% e 60\% de fíler sobre o volume de cimento. 
Figura 76 - Reprodutibilidade do espalhamento das pastas de SM400, fator a/s 0,21

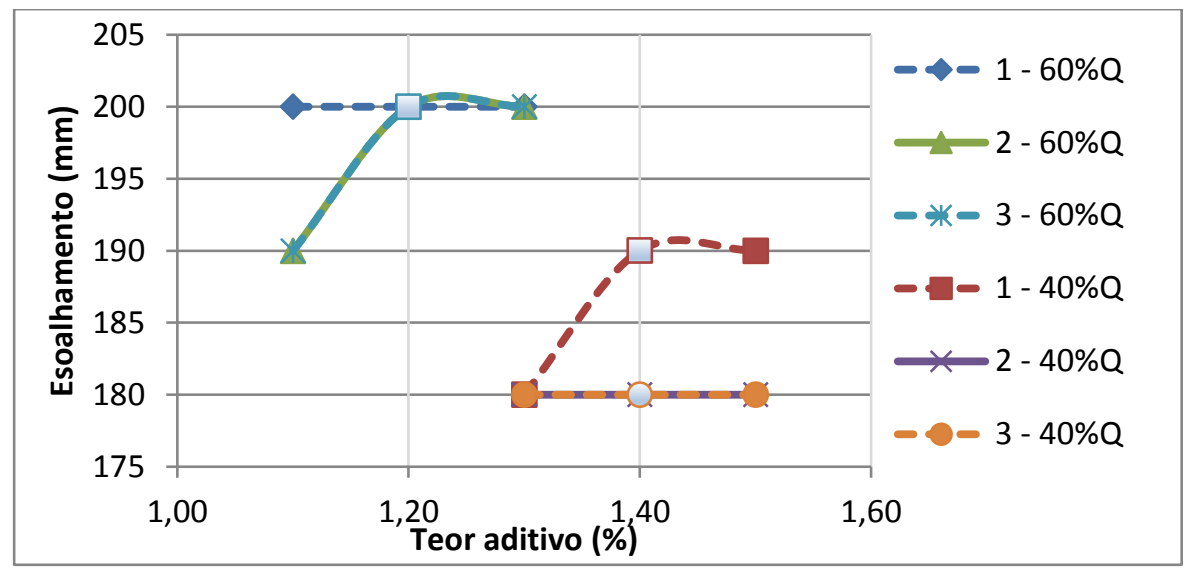

Figura 77 - Reprodutibilidade do Funil de Marsh das pastas de SM400, fator a/s 0,21

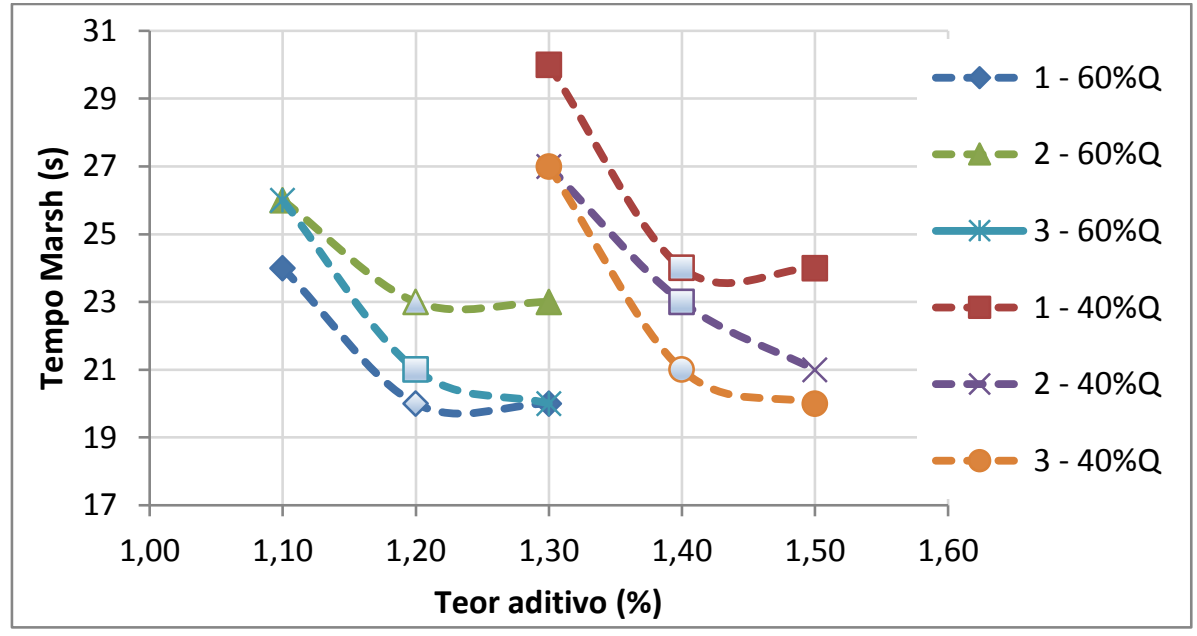

As repetições dos ensaios de espalhamento apresentaram resultados semelhantes para as pastas com 60\% de fíler (Figura 76), enquanto no Funil de Marsh, somente os ensaios 1 e 3 atingiram resultados semelhantes (Figura 77). As pastas com $40 \%$ de fíler alcançaram espalhamentos próximos nos ensaios 2 e 3, divergindo do primeiro. Nos ensaios com o Funil de Marsh, as pastas 1 e 2 apresentaram resultados próximos ao atingirem o ponto de saturação do dispersante, embora as curvas de viscosidade sejam distintas. Os teores ótimos de dispersante determinados foram os mesmos para todas as repetições.

As Figuras 78 e 79 mostram os comparativos entre as repetições dos ensaios de reologia feitos com as pastas de cimento-fíler SM400 para o teor de água 0,25. 
Figura 78 - Reprodutibilidade do espalhamento das pastas de SM400, fator a/s 0,25

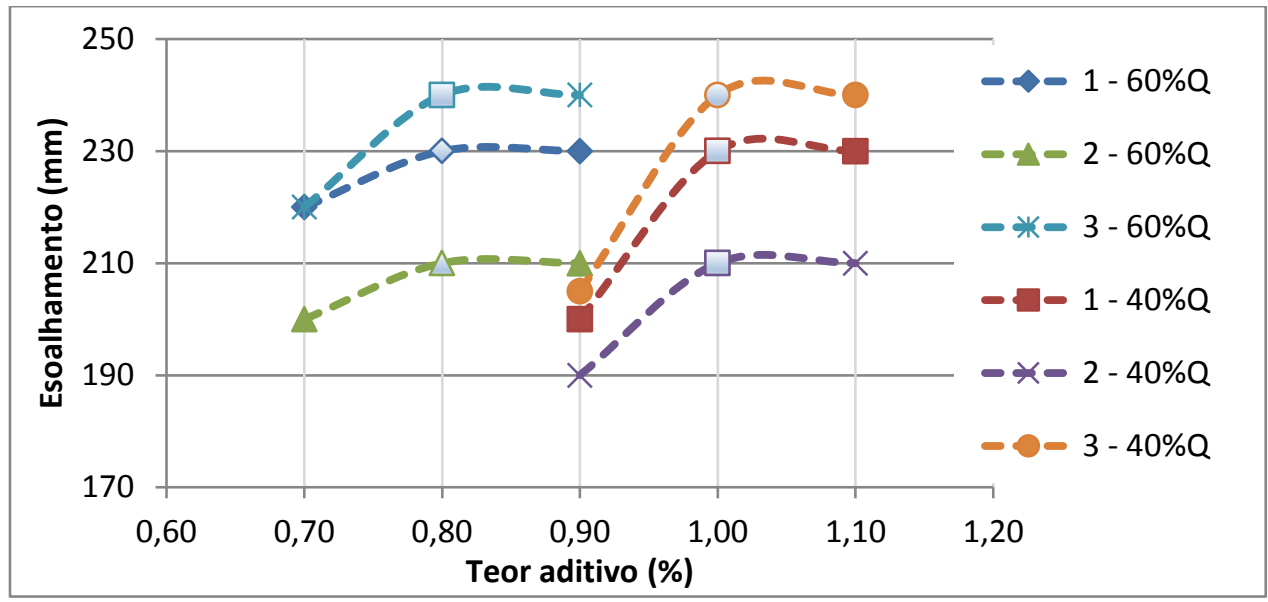

Figura 79 - Reprodutibilidade do Funil de Marsh das pastas de SM400, fator a/s 0,25

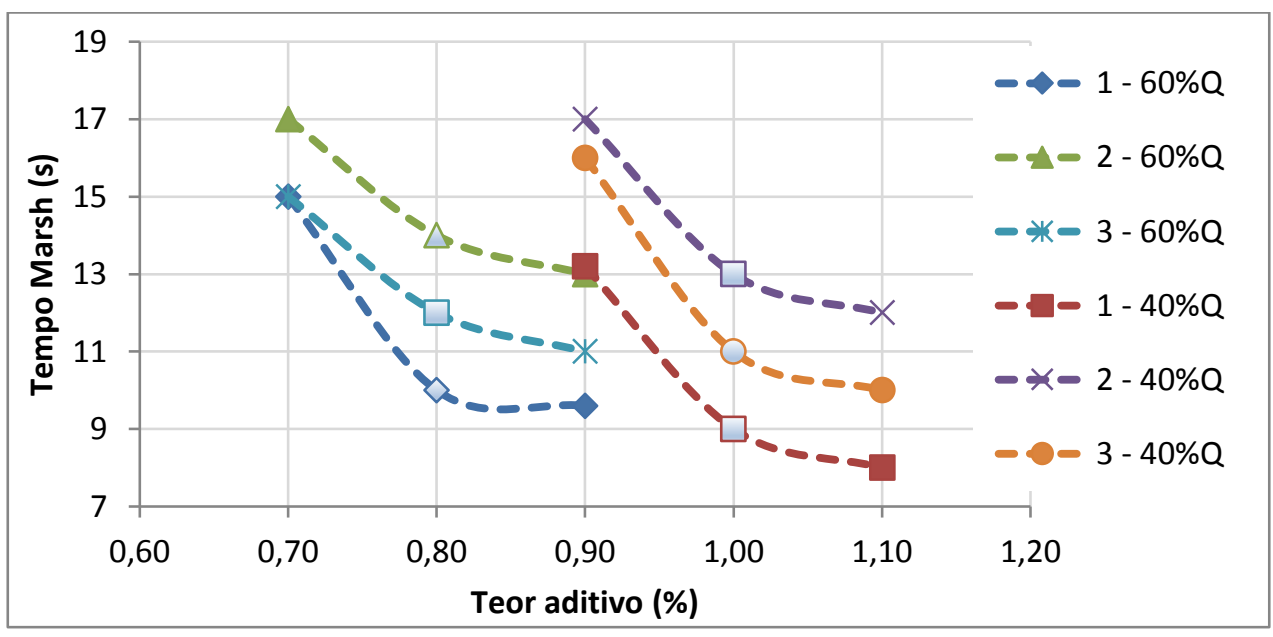

De acordo com o gráfico da Figura 78, as pastas dos ensaios 1 e 3 com 60\% de fíler atingiram espalhamentos equivalentes (diferença de $10 \mathrm{~mm}$ ), divergindo na segunda repetição. No ensaio de Funil de Marsh, as pastas 1 e 2 obtiveram curvas de viscosidade semelhantes e próximas, com $2 \mathrm{~s}$ de diferença entre os pontos. As pastas com $40 \%$ de fíler alcançaram comportamentos parecidos para o parâmetro de tensão de escoamento nos ensaios 1 e 3 (Figura 79), enquanto as curvas de viscosidade das pastas 1 e 2 demonstraram a mesma tendência com resultados distintos, além de uma maior proximidade entre os ensaios 1 e 3 com apenas $2 \mathrm{~s}$ de diferença (Figura 79).

Os ensaios de reprodutibilidade demonstraram que, além da padronização dos procedimentos de mistura e dosagem, as condições ambientais e o tempo de execução dos experimentos influenciam na reologia das misturas cimentícias, sendo necessário o controle desses parâmetros para evitar grandes variabilidades entre os resultados. 


\subsubsection{Trabalhabilidade das pastas}

Os ensaios para avaliar a trabalhabilidade das pastas seguiram os seguintes procedimentos: 1) mistura das pastas já com o teor ótimo de dispersante; 2) repetição dos ensaios de reologia (Funil de Marsh e minicone) nos tempos de 10, 20, 30, 60, 90 e 120 min, avaliando o comportamento das misturas; 3) as pastas foram remisturadas antes da execução dos ensaios. Na primeira etapa de ensaios, foram avaliadas as perdas de trabalhabilidade das pastas de cimento-fíler SM200 e SM400, por apresentarem granulometrias mais extremas, e das pastas de cimento. As Figuras 80 e 81 mostram os gráficos de trabalhabilidade das pastas com teor de água 0,21 para os ensaios de Funil de Marsh e espalhamento pelo minicone, respectivamente.

Figura 80 - Trabalhabilidade das pastas no Funil de Marsh, fator a/s 0,21

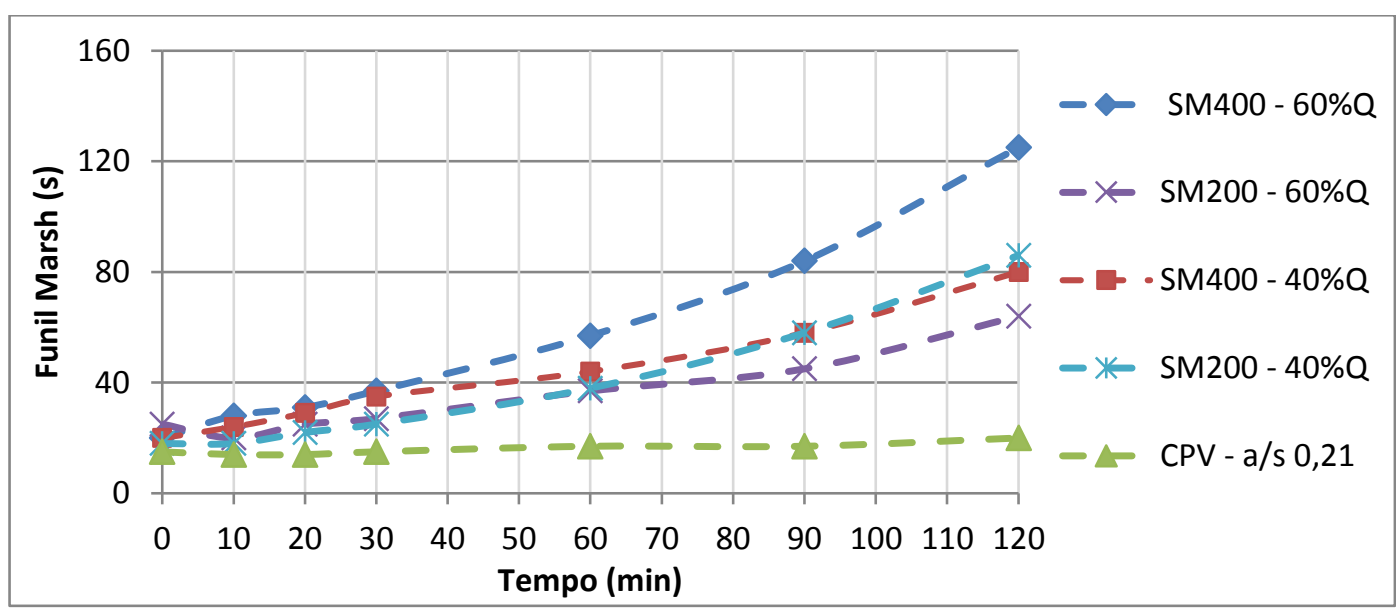

Figura 81 - Trabalhabilidade das pastas no espalhamento pelo minicone, fator a/s 0,21

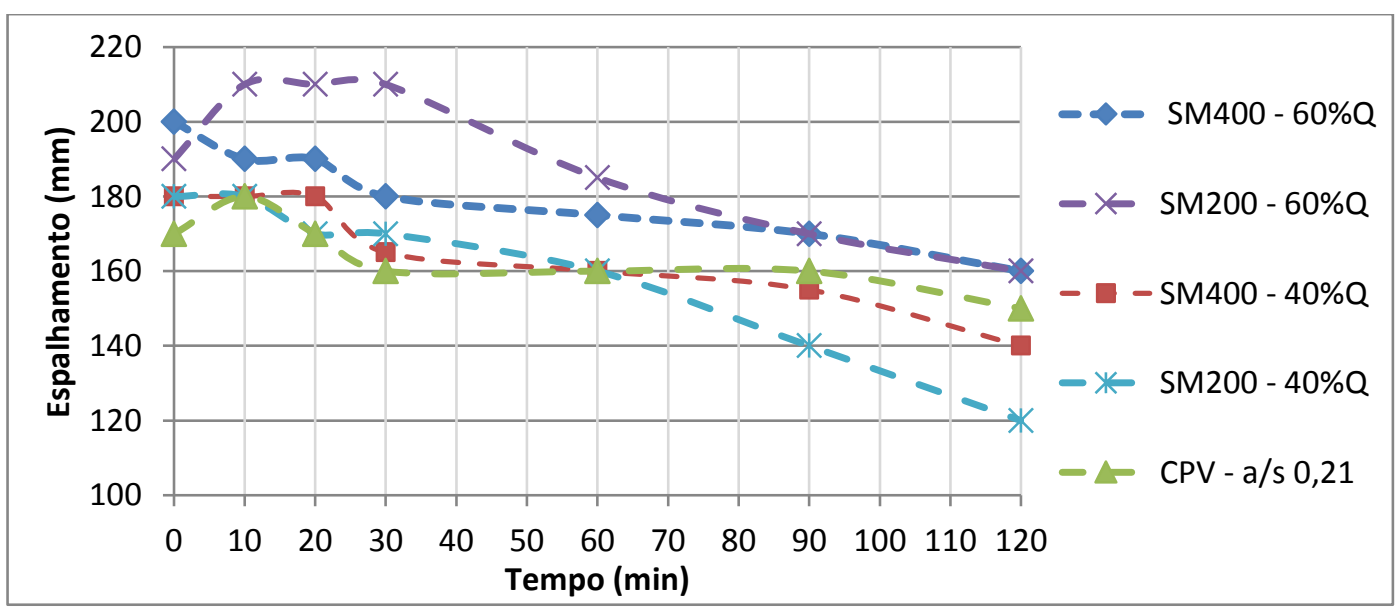

De acordo com os gráficos acima, observa-se que a pasta de cimento manteve estabilidade até o final dos ensaios, enquanto as misturas com fíleres perderam a trabalhabilidade no decorrer do tempo. No ensaio de Funil de Marsh, enquanto a pasta de 
cimento continuou estável, as pastas com $60 \%$ de fíler SM400 tiveram maior aumento de viscosidade em relação às demais misturas com fíleres, que alcançaram resultados próximos. No ensaio de espalhamento pelo minicone, a pasta de cimento teve um aumento rápido na tensão de escoamento no intervalo de tempo entre 10 e 30min, porém, após esse período, manteve seu comportamento estabilizado. As pastas com 60\%SM200 e 60\%SM400 atingiram espalhamentos superiores à pasta convencional, mesmo com perdas mais rápidas na trabalhabilidade. A pasta com 40\%SM400 atingiu valores de espalhamento próximos à pasta de CPV, com curva de comportamento reológico semelhante, enquanto a mistura com $40 \%$ SM200 teve uma maior perda de trabalhabilidade que as demais, provavelmente por influências das condições ambientais.

Diante dos resultados obtidos nos experimentos com as misturas no teor de água 0,21, foram observados comportamentos reológicos satisfatórios das pastas com o fíler SM400. Logo, na segunda etapa de experimentos, visando atingir valores próximos entre as misturas com fíleres e a convencional, foram feitos ensaios de trabalhabilidade com as pastas de cimentofíler SM400 no teor de água 0,25, comparadas à pasta de CPV no teor 0,21. As Figuras $82 \mathrm{e}$ 83 mostram os gráficos para os ensaios de Funil de Marsh e espalhamento pelo minicone, respectivamente.

Figura 82 - Trabalhabilidade das pastas com fíleres SM400 no Funil de Marsh, fator a/s 0,25

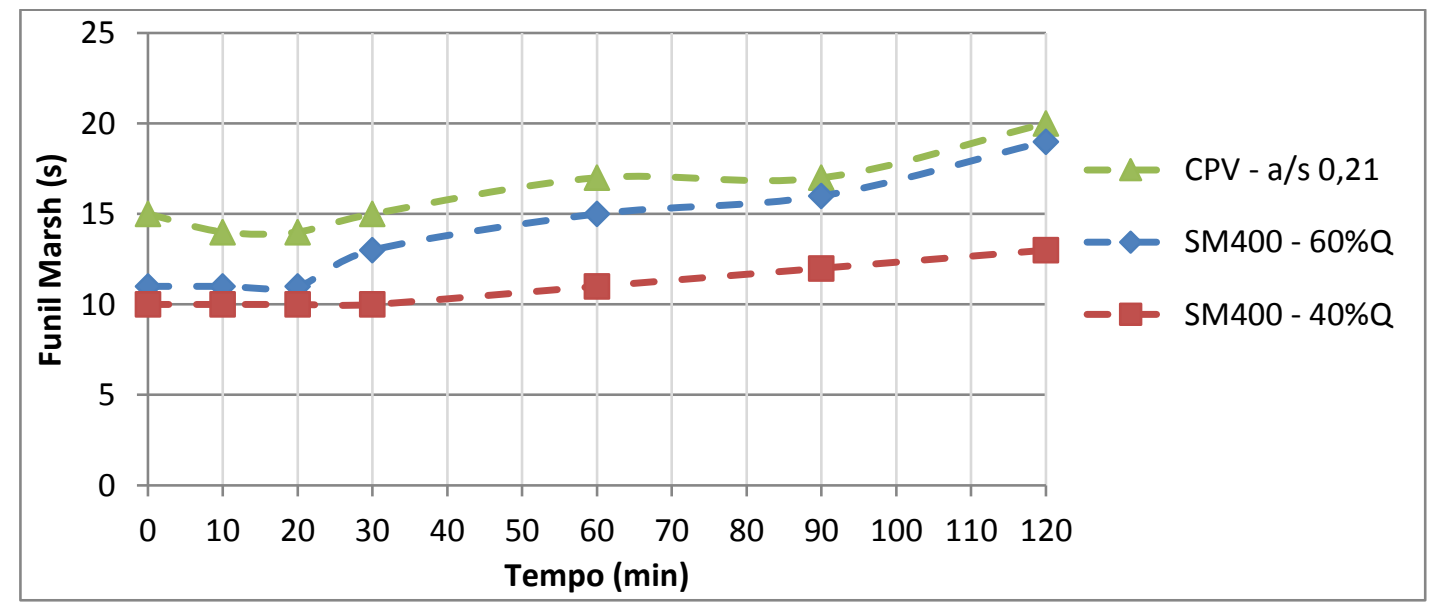

De acordo com o gráfico acima, as pastas com fíleres atingiram menor viscosidade que a pasta de cimento e a mistura com $60 \%$ de fíler alcançou resultados próximos à pasta de CPV nos min finais de ensaio. É possível destacar que a pasta com $40 \%$ de fíler, além de apresentar menor viscosidade que as demais, manteve uma trabalhabilidade mais estável. 
Figura 83 - Trabalhabilidade das pastas com fíleres no espalhamento pelo minicone, fator a/s 0,25

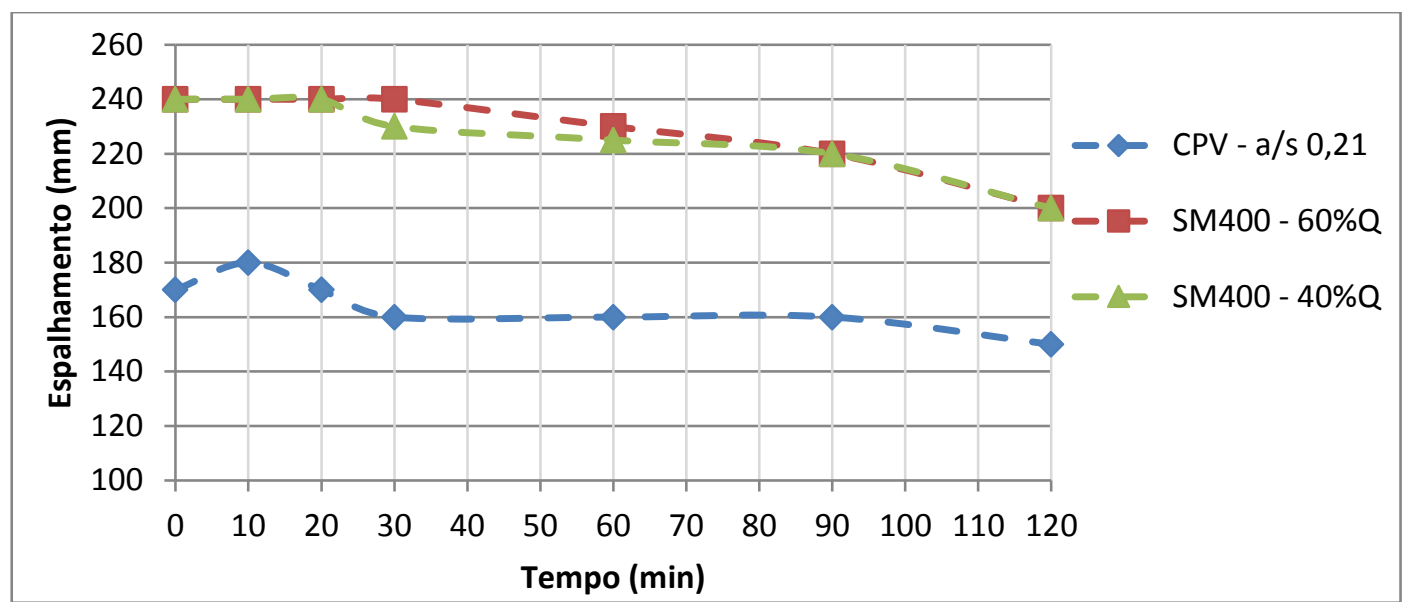

Os resultados dos experimentos mostram que as misturas com fíleres atingiram espalhamentos superiores à pasta convencional (Figura 83) e mantiveram a trabalhabilidade mais estabilizada com o aumento do teor de água de 0,21 para 0,25. Esse fator é resultado da necessidade de maiores quantidades de água para manter as partículas afastadas, evitando a perda de eficiência da atuação do dispersante. Embora as misturas de cimento-fíler com fator a/s 0,21 tenham perdido a trabalhabilidade mais rapidamente, suas resistências mecânicas poderão ser superiores às pastas com fator a/s 0,25 , por consequente aumento da porosidade com maiores teores de água. Logo, a aplicação desses materiais dependerá da rapidez de endurecimento necessária para o tempo de execução da obra e da resistência final pretendida.

\subsection{RESISTENNCIA À COMPRESSÃO DOS CORPOS DE PROVA DE PASTAS}

Os ensaios de resistência à compressão uniaxial foram feitos com amostras de pastas de cimento puro e cimento-fíler SM200, SM325 e SM400, nas substituições de 40\% e 60\% de fíler sobre o volume de cimento, para os teores de água 0,21 e 0,25. Foram moldados seis corpos de prova para as idades de 7 e 28 dias, sendo três para cada ensaio. As Figuras 84 e 85 mostram as resistências médias atingidas aos 7 e 28 dias, respectivamente, para o teor de água 0,21. 
Figura 84 - Resistência média das pastas com fator a/s 0,21 aos 7 dias

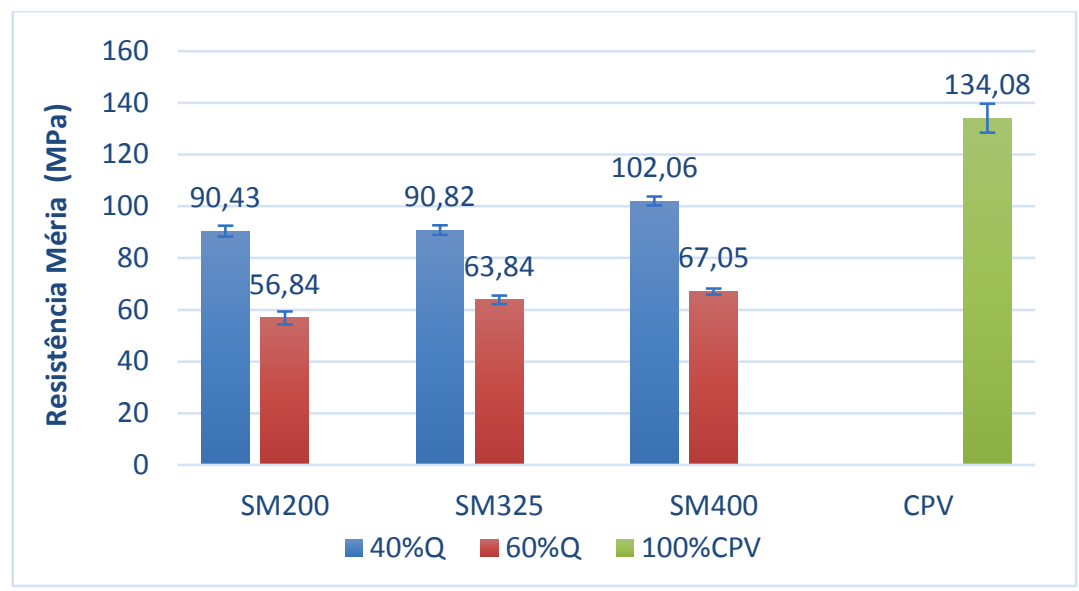

Figura 85 - Resistência média das pastas com fator a/s 0,21 aos 28 dias

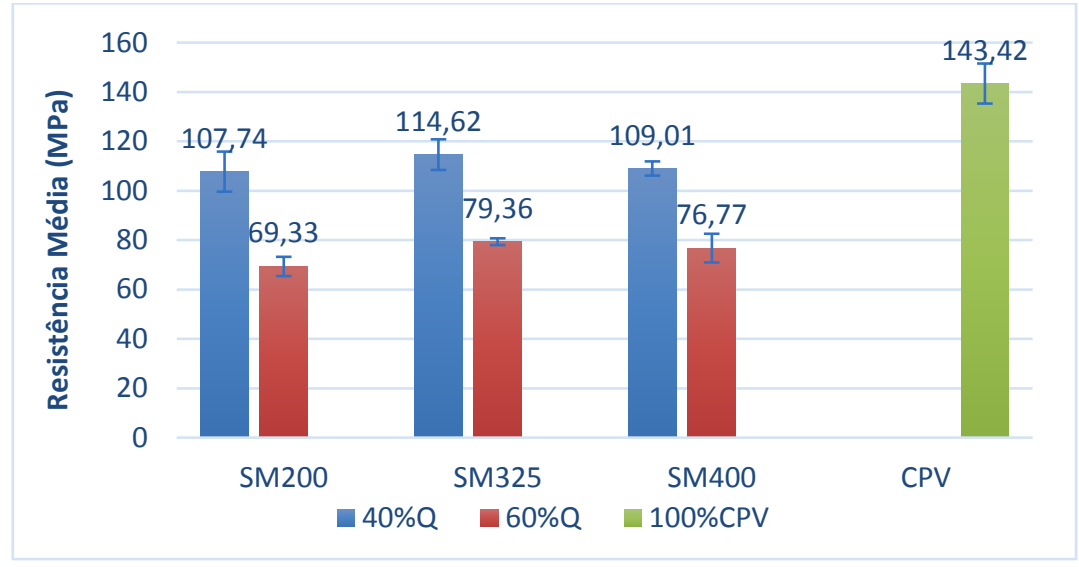

De acordo com os gráficos acima, observa-se que as pastas de cimento-fíler nas substituições de $40 \%$ de fíler sobre o volume de cimento, atingiram resistências superiores às amostras feitas com 60\%, devido ao maior teor de ligantes presentes nas misturas. Em relação à influência granulométrica, nota-se que os corpos de prova feitos com o fíler SM200, de granulometria mais grossa, tiveram desempenho mecânico inferior aos demais em ambas as idades, pois partículas mais finas tendem a preencher os poros intergranulares e melhoram o empacotamento. As pastas com cimento-fíler SM400, com granulometria mais fina, apresentaram resistência média superior em relação às demais na idade de 7 dias, porém, aos 28, as pastas de cimento-fíler SM325, de granulometria intermediária, obtiveram melhores resultados. A Tabela 9 mostra os resultados com desvio padrão dos ensaios de resistência à compressão das pastas aos 7 e 28 dias, em que RC é a resistência mecânica média e DP é o desvio padrão. 
Tabela 9 - Desvio padrão dos resultados de resistência à compressão das pastas aos 7 e 28 dias

\begin{tabular}{|c|c|c|c|c|c|c|c|}
\hline \multicolumn{8}{|c|}{ RESISTÊNCIA MECÂNICA DAS PASTAS } \\
\hline DOSAG & ER & $\mathrm{A} / \mathrm{C}$ & $\mathrm{A} / \mathrm{S}$ & $\mathrm{RC7}$ & DP7 & $\mathrm{RC} 28$ & DP28 \\
\hline SM 200 & \multirow{3}{*}{$40 \%$} & \multirow{3}{*}{0,33} & \multirow{7}{*}{0,21} & 90,23 & 2,09 & 107,74 & 8,11 \\
\hline SM 325 & & & & 90,82 & 1,84 & 114,62 & 6,2 \\
\hline SM 400 & & & & 102,06 & 1,74 & 109,01 & 2,88 \\
\hline CPV & $0 \%$ & 0,21 & & 134,08 & 5,59 & 143,42 & 8,11 \\
\hline SM 200 & \multirow{3}{*}{$60 \%$} & \multirow{3}{*}{0,48} & & 56,84 & 2,52 & 69,33 & 3,9 \\
\hline SM 325 & & & & 63,84 & 1,65 & 79,36 & 1,37 \\
\hline SM 400 & & & & 67,05 & 1,16 & 76,77 & 5,81 \\
\hline
\end{tabular}

Diante da revisão bibliográfica estudada, era esperado que as amostras com fíler mais fino (SM400) atingissem resistências médias superiores em todas as misturas, porém houveram divergências nos resultados de ruptura aos 28 dias, devido ao elevado desvio padrão das amostras com $40 \%$ SM325 e das pastas com 60\% SM400.

As Figuras 86 e 87 descrevem os resultados de resistência à compressão dos corpos de prova aos 7 e 28 dias para o teor de água 0,25 .

Figura 86 - Resistência média das pastas com fator a/s 0,25 aos 7 dias

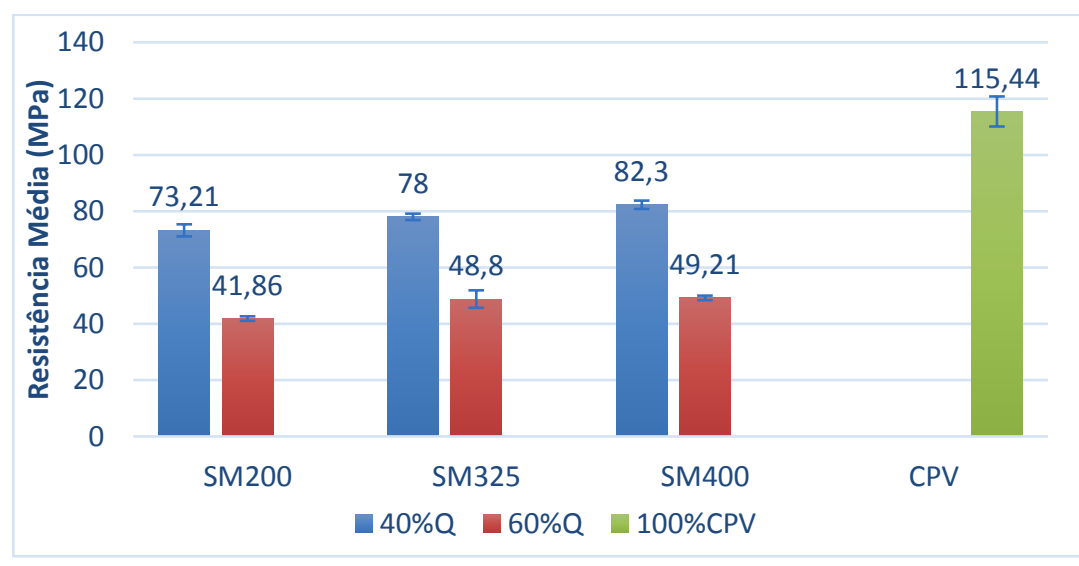

Figura 87 - Resistência média das pastas com fator a/s 0,25 aos 28 dias

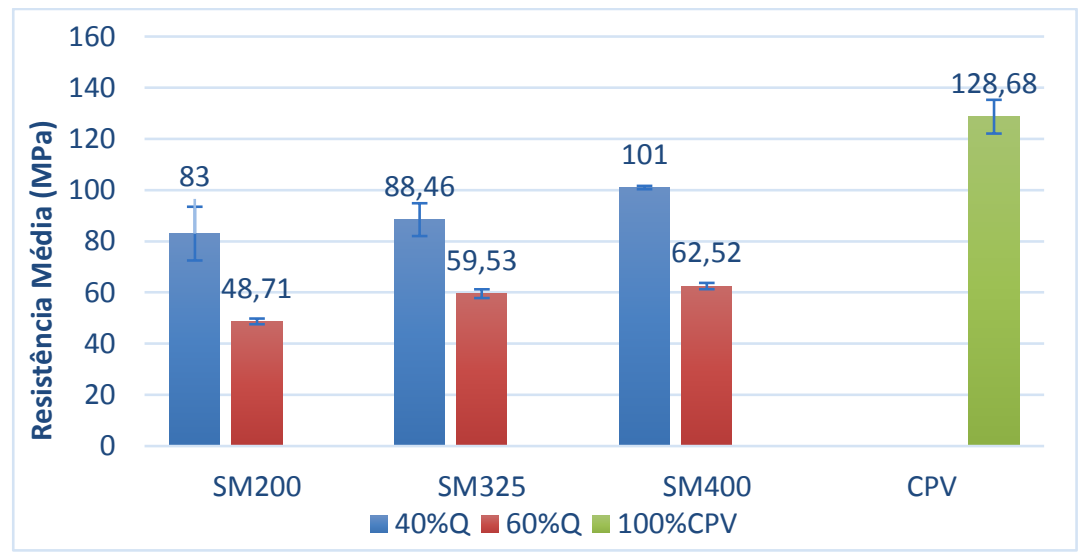


De acordo com os gráficos acima, observa-se uma redução do desempenho mecânico, quando comparado às pastas com teor de água 0,21 , devido ao aumento da porosidade proporcionada pela inserção de maior quantidade de fluido no sistema. As misturas feitas com o fíler SM200 apresentaram resultados inferiores às demais em ambas as idades, para as duas porcentagens de substituição. As amostras com SM325 e SM400 atingiram resultados próximos aos 7 dias e, aos 28 dias, porém as pastas com SM400 alcançaram um melhor desempenho, devido a maior finura das partículas que contribuem para a diminuição da porosidade. A Tabela 10 mostra os resultados com desvio padrão dos ensaios para ambas as idades, em que RC é a resistência mecânica média e DP é o desvio padrão.

Tabela 10 - Desvio padrão dos resultados de resistência à compressão das pastas aos 7 e 28 dias

\begin{tabular}{|c|c|c|c|c|c|c|c|}
\hline \multicolumn{8}{|c|}{ RESISTÊNCIA MECÂNICA DAS PASTAS } \\
\hline DOSAGI & LER & $\mathrm{A} / \mathrm{C}$ & $\mathrm{A} / \mathrm{S}$ & RC7 & DP7 & $\mathrm{RC} 28$ & DP28 \\
\hline SM 200 & & & \multirow{7}{*}{0,25} & 72,21 & 2,15 & 83 & 10,49 \\
\hline SM 325 & $40 \%$ & 0,39 & & 78 & 1,14 & 88,46 & 6,41 \\
\hline SM 400 & & & & 82,3 & 1,48 & 101 & 0,65 \\
\hline $\mathrm{CPV}$ & $0 \%$ & 0,25 & & 115,44 & 5,34 & 128,68 & 6,59 \\
\hline SM 200 & \multirow{3}{*}{$60 \%$} & \multirow{3}{*}{0,57} & & 41,86 & 0,8 & 48,71 & 1,11 \\
\hline SM 325 & & & & 48,8 & 3,1 & 59,53 & 1,71 \\
\hline SM 400 & & & & 49.21 & 0,82 & 62,52 & 1,22 \\
\hline
\end{tabular}

\subsection{RESISTÊNCIA À COMPRESSÃO DOS CORPOS DE PROVA DE ARGAMASSAS}

Os ensaios de resistência à compressão das argamassas foram feitos com misturas de cimento puro e cimento-fíler SM200, SM325 e SM400, nas substituições de 40\% e 60\% de fíler sobre o volume de cimento. Foram moldados 6 corpos de prova, sendo 3 para cada idade de ruptura, com teores de água variáveis para uma consistência fixa de $240 \mathrm{~mm}$ de espalhamento, e teor de dispersante fixado em $0,80 \%$ em volume. As Figuras 88 e 89 mostram os resultados de resistência mecânica média dos corpos de prova aos 7 e 28 dias. 
Figura 88 - Resistência média das argamassas aos 7 dias

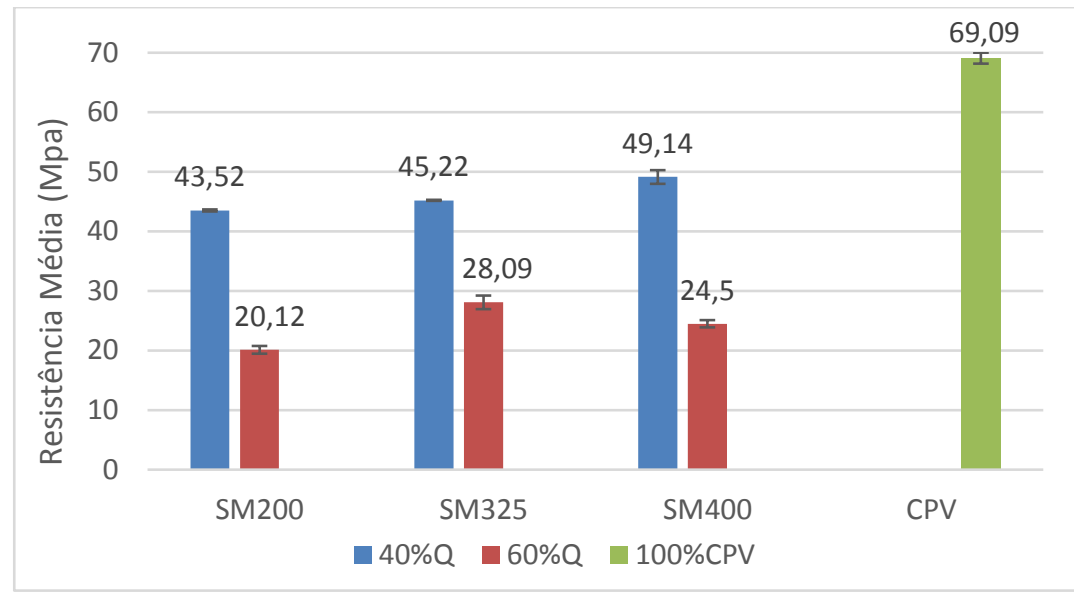

Figura 89 - Resistência média das argamassas aos 28 dias

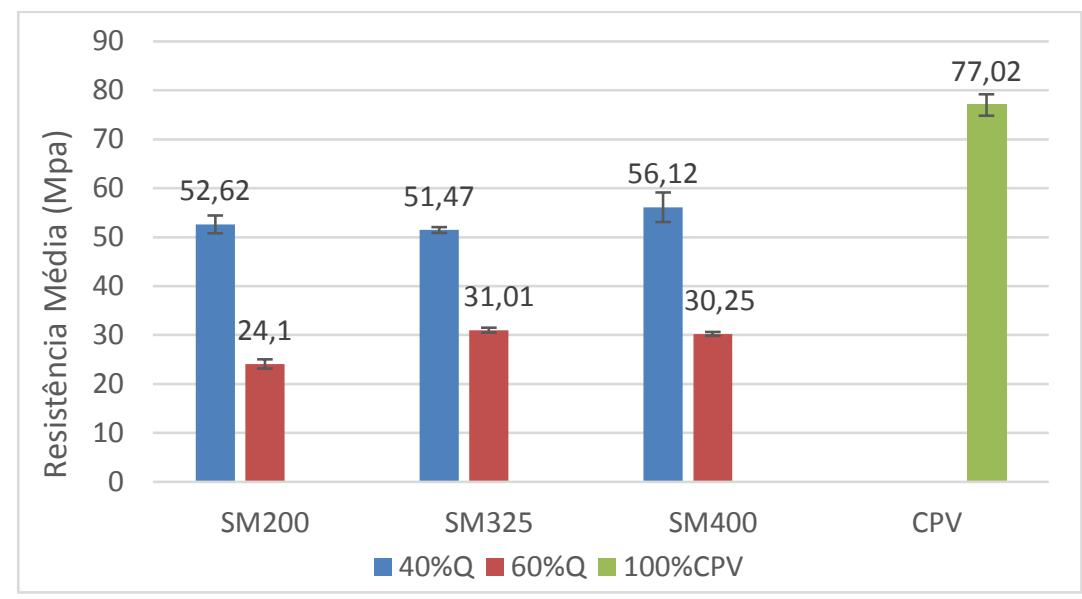

De acordo com os gráficos acima, observa-se que as argamassas com $40 \%$ de fíler tiveram desempenhos melhores em relação às com 60\%, devido ao maior teor de ligantes presentes nas misturas. Aos 7 dias, as amostras com 40\% SM400 atingiram resistências superiores às demais argamassas com fíleres, porém, entre as dosagens com $60 \%$ de substituição, os corpos de prova com 60\% SM325 alcançaram melhores resultados. Aos 28 dias, as amostras com 40\% SM200 e 40\% SM325 alcançaram resultados próximos e inferiores às argamassas com 40\% SM400. Entre as misturas com $60 \%$ de fíler, os corpos de prova com $60 \%$ SM325 e 60\% SM400 atingiram desempenhos equivalentes e superiores às argamassas com $60 \%$ SM200. A Tabela 11 mostra os resultados com desvio padrão dos ensaios para ambas as idades, em que RC é a resistência mecânica média e DP é o desvio padrão. 
Tabela 11 - Desvio padrão dos resultados de resistência à compressão das argamassas aos 7 e 28 dias

\begin{tabular}{cc|cc|cc|cc}
\hline \multicolumn{7}{c}{ RESISTÊNCIA MECÂNICA DAS ARGAMASSAS } \\
\hline \multicolumn{2}{l|}{ DOSAGEM FÍLER } & A/C & A/S & RC7 & DP7 & RC28 & DP28 \\
\hline \multicolumn{2}{l|}{ SM 200 } & 0,48 & 0,27 & 43,52 & 0,17 & 52,62 & 1,82 \\
SM 325 & \multirow{2}{*}{$40 \%$} & 0,48 & 0,27 & 45,22 & 0,09 & 51,47 & 0,59 \\
SM 400 & & 0,44 & 0,25 & 49,14 & 1,15 & 56,12 & 3,02 \\
\hline CPV & $0 \%$ & 0,30 & 0,30 & 69,09 & 0,92 & 77,02 & 2,19 \\
\hline SM 200 & \multirow{2}{*}{$60 \%$} & 0,86 & 0,31 & 20,12 & 0,65 & 24,10 & 0,94 \\
SM 325 & 0,72 & 0,26 & 28,09 & 1,14 & 31,01 & 0,50 \\
SM 400 & & 0,80 & 0,29 & 24,50 & 0,61 & 30,25 & 0,39 \\
\hline
\end{tabular}

A Figura 90 mostra um comparativo entre as resistências médias atingidas pelas argamassas e o fator água sólidos determinado no ensaio de consistência.

Figura 90 - Resistência à compressão média aos 28 dias x fator a/s

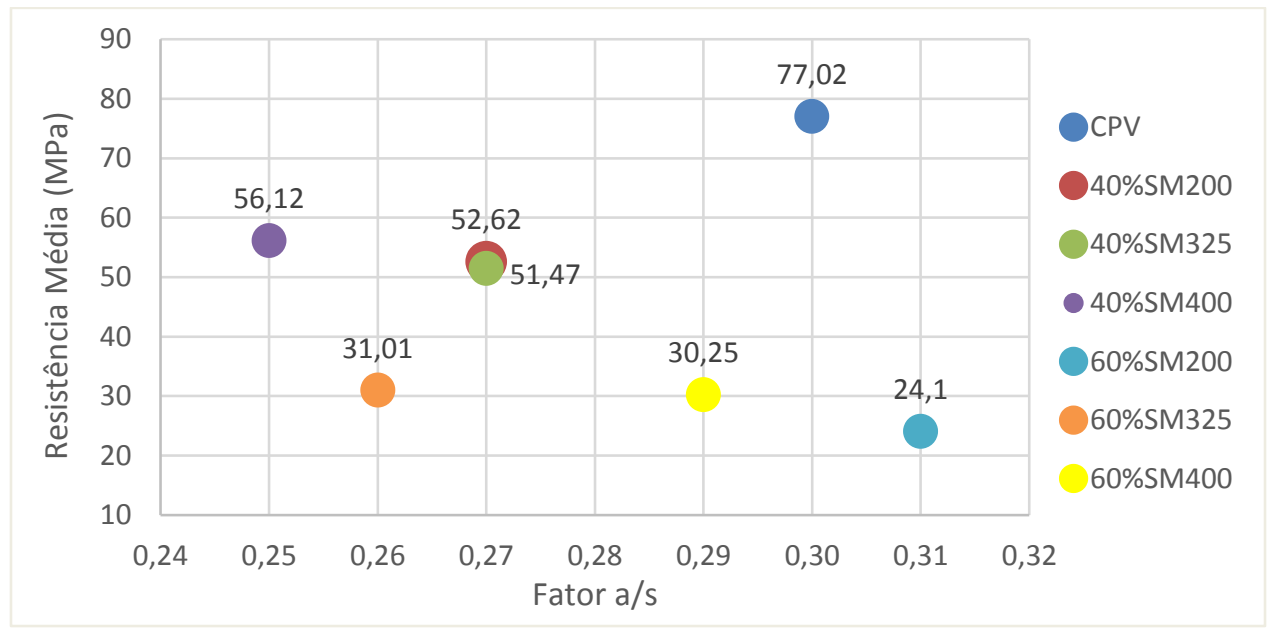

Diante dos resultados obtidos nos ensaios de resistência à compressão das pastas e argamassas, é necessário destacar que, embora tenha ocorrido uma diminuição do desempenho mecânico com a adição de fíleres, esse pode ter ocorrido em menor grau que a redução do consumo de cimento na matriz, fator que pode ser comprovado pelo cálculo do índice de eficiência ao final do presente trabalho.

\subsection{MÓDULO DE ELASTICIDADE DAS ARGAMASSAS}

Os ensaios para determinação do módulo de elasticidade foram realizados com 2 amostras de argamassas para cada dosagem, nas idades de 28 dias, previamente secas em estufa 
até estabilização das massas. A seguir, a Figura 91 mostra o comparativo entre os módulos de elasticidade médios e o consumo de cimento das argamassas produzidas.

Figura 91 - Módulo de elasticidade médio das argamassas x Consumo de cimento

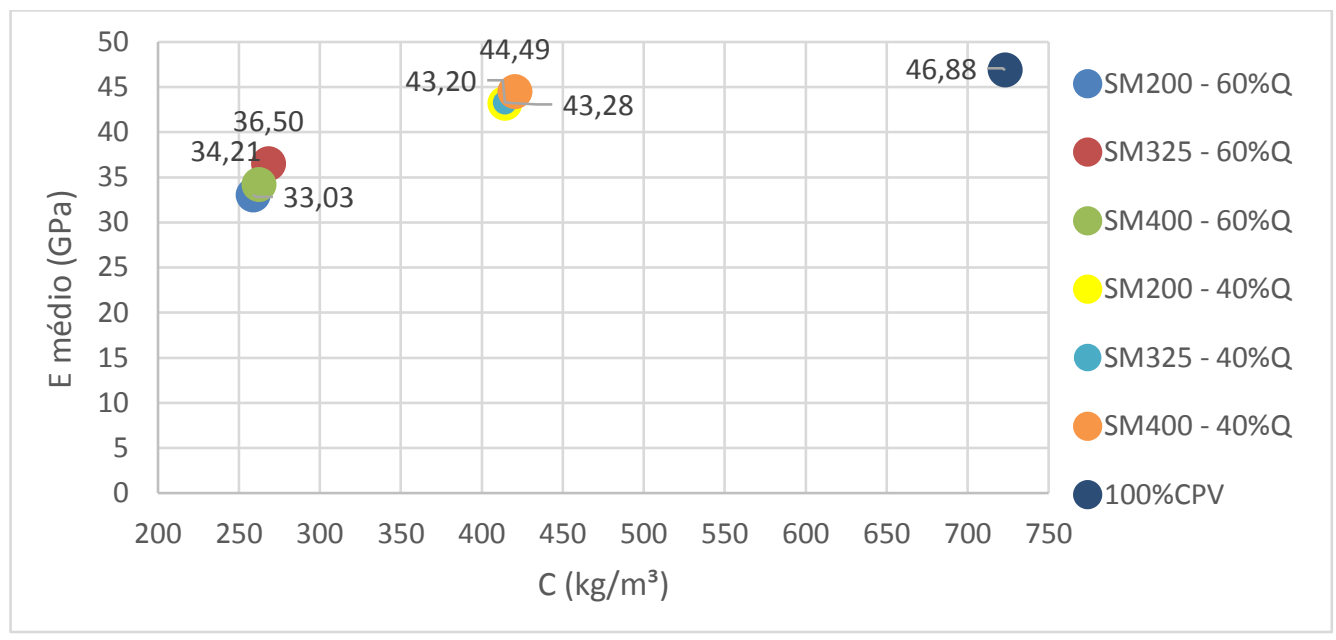

De acordo com o gráfico acima, observa-se que as argamassas produzidas com $60 \%$ de fíler obtiveram módulos de elasticidade inferiores às demais misturas, entre elas, a dosagem com 60\% SM325 obteve valores superiores, enquanto as outras atingiram resultados equivalentes. As três argamassas produzidas com $40 \%$ de fíler alcançaram resultados semelhantes entre si e muito próximos às amostras feitas com cimento puro, demonstrando rigidez equivalentes com menor consumo de cimento (cerca de $300 \mathrm{~kg} / \mathrm{m}^{3}$ a menos). A Tabela 12 mostra os resultados dos ensaios com os dados de desvio padrão.

Tabela 12 - Desvio padrão dos módulos de elasticidade das argamassas

\begin{tabular}{cccc}
\hline \multicolumn{4}{c}{ Módulo de Elasticidade Médio das Argamassas } \\
\hline Argamassas & $\mathrm{C}\left(\mathrm{kg} / \mathrm{m}^{3}\right)$ & $\mathrm{Em}(\mathrm{GPa})$ & Desvio Padrão \\
\hline SM200 - 60\%Q & 258,64 & 33,03 & 0,21 \\
SM325 - 60\%Q & 268,27 & 36,50 & 0,60 \\
SM400 - 60\%Q & 262,41 & 34,21 & 0,34 \\
SM200 - 40\%Q & 414,27 & 43,20 & 0,05 \\
SM325 - 40\%Q & 414,27 & 43,28 & 0,6 \\
SM400 - 40\%Q & 420,49 & 44,49 & 0,6 \\
100\%CPV & 723,05 & 46,88 & 0,83 \\
\hline
\end{tabular}

Os resultados obtidos tiveram pouco desvio entre si e comprovam que é possível produzir argamassas com rigidez satisfatórias utilizando menores teores de ligantes. É necessário destacar que, mesmo as dosagens com 60\% de fíler alcançaram módulos de elasticidade proporcionalmente altos comparados à redução do teor de cimento nas misturas, 
com diferenças médias em torno de 10GPa em relação ao material convencional e uma redução de cerca de $450 \mathrm{~kg} / \mathrm{m}^{3}$ no consumo de cimento.

\section{6 ÍNDICE DE EFICIÊNCIA (BI)}

O potencial dos materiais produzidos para redução do consumo de cimento foi avaliado através do cálculo de eficiência Binder Intensity (BI) para as pastas e argamassas. Embora tenham ocorrido quedas na resistência mecânica com a introdução de fíleres nas misturas cimentícias (itens 5.3 e 5.4), o consumo de cimento pôde ser reduzido em proporção maior que a diminuição do desempenho mecânico de algumas dosagens, conforme os resultados expostos a seguir.

\subsection{1 Índice de Eficiência das Pastas}

Os cálculos de eficiência das pastas foram feitos com os resultados de resistência à compressão obtidos aos 28 dias, das misturas nos teores de água 0,21 e 0,25. As pastas de cimento puro foram pontuadas com índice de eficiência nulos, a fim de serem utilizadas como referência para os valores das pastas de cimento-fíler. O cálculo do BI relaciona o consumo de cimento com a resistência mecânica do material aos 28 dias (item 4.1.7), determinando-se o ganho ou a perda de eficiência do material com filer em relação ao convencional (cimento puro) de índice relativo adotado como 0 . A Figura 92 compara o consumo de cimento com os índices de eficiência das pastas no teor de água 0,21.

Figura 92 - Índice de eficiência das pastas com fator a/s 0,21

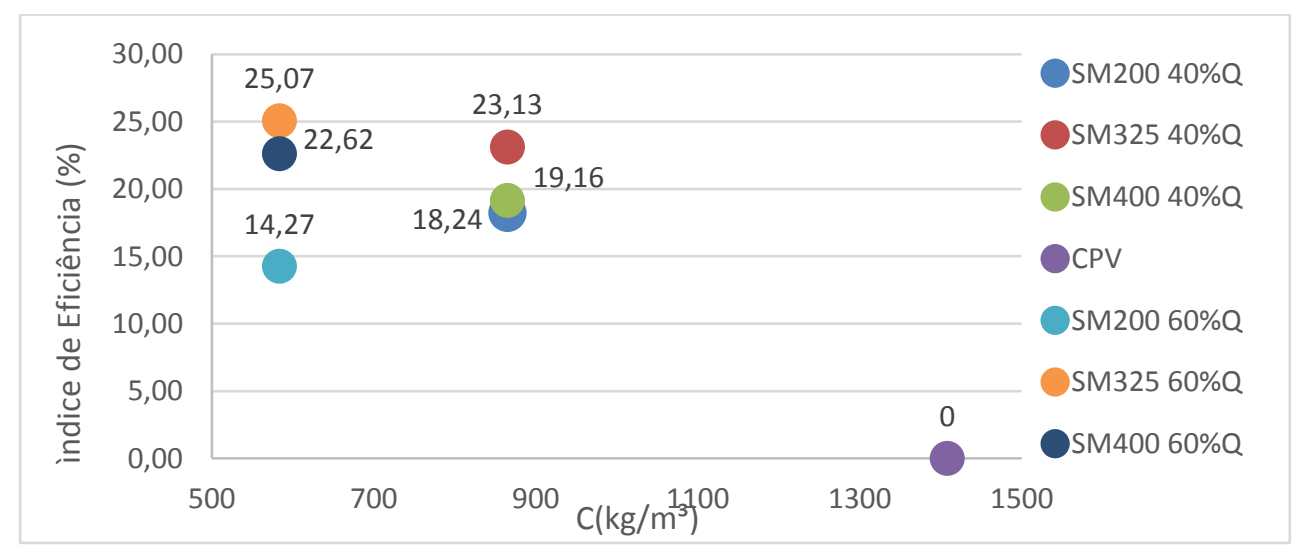

De acordo com o gráfico acima, todas as pastas feitas com fíleres no teor de água 0,21 alcançaram índices de eficiência positivos em relação à pasta convencional. As misturas com 
melhores índices foram as com 60\% SM325, com eficiência de 25,07\%, 40\% SM325 com, $23,13 \%$, e $60 \%$ SM400, com 22,62\%.

A Figura 93 mostra a relação entre o consumo de cimento e os índices de eficiência alcançados pelas pastas no teor de água 0,25 .

Figura 93 - Índice de eficiência das pastas com fator a/s 0,25

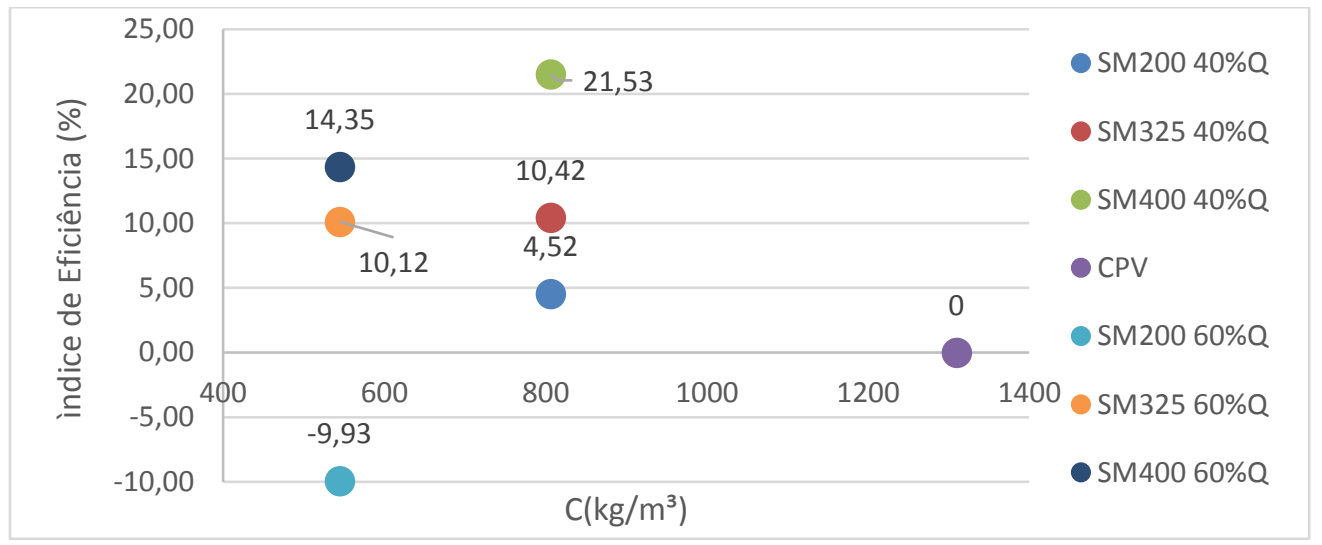

Para o fator a/s 0,25, as pastas com melhores índices foram as com 40\%SM400, com eficiência de $21,53 \%$ e $60 \%$ SM400, com 14,35\%. As misturas com 40\% SM325 e 60\%SM325 atingiram índices próximos de 10,42\% e 10,12\%, respectivamente. A dosagem com $60 \%$ SM200 obtive índice de eficiência negativo de - 9,93\%. É possível observar que, em ambos os gráficos, as pastas feitas com os fíleres SM325 e SM400, com granulometria intermediária e fina, respectivamente, atingiram resultados superiores às demais, enquanto as pastas feitas com o fíler SM200, de granulometria maior, tiveram menores índices comparados às demais misturas com fíleres.

\subsection{2 Índice de Eficiência das Argamassas}

A Figura 94 mostra os comparativos entre os consumos de cimento e os índices de eficiência alcançados pelas argamassas produzidas. A argamassa de cimento puro foi apontada com índice nulo como referência de cálculo para as argamassas de cimento-fíler. 
Figura 94 - Índice de Eficiência das argamassas x Consumo de cimento

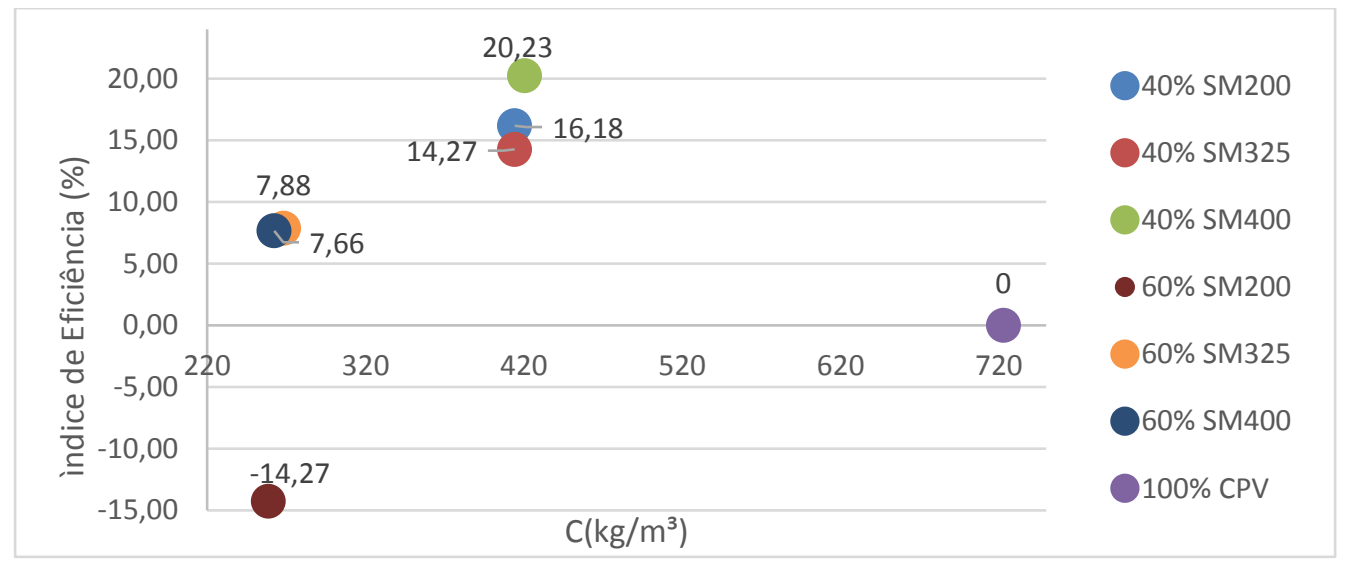

De acordo com o gráfico acima, a maioria das argamassas produzidas atingiram resultados positivos em relação à convencional, exceto a com 60\% SM200 (índice -14,27\%). As misturas com melhores resultados foram as com 40\% SM400, índice 20,23\%, 40\% SM200, com 16,18\%, e 40\% SM325, com 14,27\%. As argamassas com 60\% SM325 e 60\% SM400 atingiram eficiências equivalentes de 7,88\% e 7,66\%, respectivamente. Os dados obtidos mostram que as argamassas produzidas com fíleres, principalmente com $40 \%$ de substituição em relação ao volume de cimento, são materiais com desempenho satisfatório e menor impacto ambiental, com possibilidade de aplicação na construção civil.

\subsection{CONSIDERAÇÕES FINAIS}

$\mathrm{O}$ aumento do aquecimento global, devido à recuperação econômica dos países mais influentes, juntamente com o previsto crescimento da demanda por cimento para melhoria das infraestruturas locais, torna as exigências para redução das emissões, previstas no Acordo de Paris, inalcançáveis. Logo, é imprescindível propor estratégias para reduzir a degradação ambiental, além das que já vêm sendo utilizadas, principalmente as relacionadas ao setor da construção civil. Diante desse cenário, a presente pesquisa propõe o uso eficiente dos ligantes na formulação de materiais cimentícios por meio da adição de fíleres inertes de matérias-primas baratas e abundantes, de modo a produzir materiais com menor teor de clínquer e bom desempenho.

A eficiência dos ligantes nos sistemas cimento-fíler necessita de um controle reológico adequado que garanta comportamentos satisfatórios para baixas e altas tensões de cisalhamento, avaliando os parâmetros de tensão de escoamento e viscosidade, respectivamente. A adição de água na suspensão deve ser controlada com o uso da dosagem ideal de dispersante, 
determinando o teor mínimo necessário para manter as partículas dispersas e proporcionar máxima trabalhabilidade ao sistema. Além disso, é imprescindível avaliar as características granulométricas dos fíleres adicionados, como o fator de forma, a área superficial e o tamanho das partículas, que influenciam na demanda por água na suspensão.

A adição de finos com menor área superficial e maior granulometria reduz a influência das forças de superfície e das forças de massa, respectivamente, apresentando menor tendência à floculação e melhor atuação do dispersante. Em relação ao fator forma, as partículas com formatos próximos ao esférico favorecem o preenchimento dos vazios intergranulares, reduzindo a porosidade por meio da melhoria do empacotamento e da consequente redução do teor de água no sistema. Esses fatores, somados à dosagem correta dos componentes da mistura, proporcionam desempenhos mecânicos e reológicos próximos ao material convencional com menor teor de ligantes. 


\section{CONCLUSÕES}

As principais conclusões diante dos resultados obtidos foram:

- Para as pastas com fíleres de quartzo puros, foi possível verificar comportamentos reológicos divergentes das pastas de cimento. Os ensaios feitos no Funil de Marsh para analisar a viscosidade das suspensões demonstraram que as pastas de fíleres apresentaram comportamento dilatante, ou seja, quando submetidas à altas tensões de cisalhamento, aumentam de volume e se tornam mais viscosas. Nos ensaios de espalhamento pelo minicone, as pastas de fíler manifestaram baixas tensões de escoamento, atingindo diâmetros de espalhamento superiores às com cimento puro. Embora as pastas de fíler de quartzo, sem interação com o cimento, tenham exigido maiores teores de água e de dispersante, ao serem inseridas no sistema cimento-fíler, promoveram melhorias reológicas que permitiram a redução do teor de água e de dispersante. É necessário destacar que a influência do clima, como a temperatura e a umidade, gera desvios nos resultados, devido à alta área superficial dos fíleres que faz com que as partículas sejam mais sensíveis ao dispersante quando comparadas ao cimento puro. Portanto, o uso desses finos em materiais cimentícios requer maior controle tecnológico na dosagem dos dispersantes.

- Para as misturas de cimento-fíler, é importante ressaltar que as pastas com $60 \%$ de fíler, quando comparadas às misturas feitas com $40 \%$ de substituição, para um mesmo fíler, atingiram maior fluidez. Os resultados dos comportamentos reológicos das misturas cimentofíler, para ambos os parâmetros (viscosidade e tensão de escoamento) evidenciam que a incorporação de fíleres nas pastas proporciona melhorias na reologia quando comparadas às pastas de cimento puro. Entretanto, os experimentos realizados para avaliar a trabalhabilidade das suspensões demonstraram que as pastas feitas com menor teor de água (fator a/s 0,21) obtiveram perdas reológicas mais rapidamente, enquanto a pasta de cimento permaneceu estável por mais tempo. A adição de maiores teores de água (fator a/s 0,25), além de promover melhor trabalhabilidade às pastas de cimento-fíler comparadas à convencional, permitiu que as misturas permanecessem mais estáveis até o final dos ensaios, fator que pode ser explicado pela melhor atuação do dispersante para manter as partículas afastadas com maiores teores de água. Embora as pastas de cimento-fíler com teor de água 0,21 tenham perdido a trabalhabilidade com maior rapidez, as resistências mecânicas das misturas no estado endurecido foram superiores às pastas com fator a/s 0,25, devido à menor porosidade gerada nos sistemas. Logo, o uso desses materiais na construção civil deverá considerar a trabalhabilidade necessária para o tempo de aplicação e a resistência final pretendida. 
- Os ensaios de resistência à compressão permitiram observar que as pastas e argamassas com fíleres atingiram resistências inferiores aos materiais convencionais. As misturas feitas com substituição de $60 \%$ de fíleres sobre o volume de cimento atingiram resistências inferiores às pastas e argamassas com $40 \%$ de fíler, devido ao menor teor de ligantes nos sistemas. O teor de água incorporado nas misturas também influenciou nos resultados, pois os materiais com fator a/s 0,21 tiveram melhor desempenho mecânico. Em relação à influência granulométrica das adições, os corpos de prova das pastas feitas com fíler SM200, com partículas mais grossas, atingiram resistências inferiores às demais misturas e as pastas com os fíleres SM325 e SM400, de granulometrias intermediária e mais fina, respectivamente, tiveram desempenhos próximos. Os resultados de compressão das pastas apresentaram altos desvios, devido à sensibilidade às variações dos teores de dispersante e de água, além da temperatura e umidade do ambiente no momento de mistura e moldagem. Em relação às argamassas, os desvios dos resultados foram insignificantes, devido a um maior controle das variações climáticas durante a execução dos ensaios, assim as pastas com os fíleres SM325 e SM400 atingiram resistências próximas entre si e superiores às argamassas com o fíler SM200. Esses resultados demonstraram que as partículas mais finas proporcionam uma melhoria no empacotamento por meio do preenchimento dos poros intergranulares, contribuindo para a redução da necessidade de água na mistura e aumentando a resistência mecânica do material.

- A avaliação dos módulos de elasticidade das argamassas comprovou que as amostras com $40 \%$ e $60 \%$ de fíler apresentam rigidez satisfatórias, com destaque para as misturas com $40 \%$ de fíler, que obtiveram resultados muito próximos aos corpos de prova convencionais com redução em torno de $300 \mathrm{~kg} / \mathrm{m}^{3}$ no consumo de cimento. As argamassas com $60 \%$ de fíler atingiram módulos de elasticidade com diferenças de apenas $10 \mathrm{GPa}$ em relação ao material convencional, proporcionando uma redução de cerca de $450 \mathrm{~kg} / \mathrm{m}^{3}$ no consumo de cimento.

- O cálculo do índice de eficiência das pastas demonstrou que todas as misturas de cimento-fíler com teor de água 0,21 apresentam ganhos de eficiência em relação à pasta convencional, com ganho máximo de 25,07\% alcançado pela mistura com 60\% SM325, sendo superiores aos índices atingidos pelas pastas com teor de água 0,25, com valor máximo de $21,53 \%$ atingido pela pasta com 40\% SM400. Somente a amostra feita com 60\% SM200 no fator a/s 0,25 , obteve índice de eficiência negativo de $-9,93 \%$ em relação à pasta de cimento. É importante salientar que as misturas feitas com os fíleres de granulometria intermediária e fina, SM325 e SM400, respectivamente, apresentaram ganhos de eficiência próximos e superiores às misturas feitas com o fíler SM200, de granulometria mais grossa. Para as 
argamassas, a maioria das misturas de cimento-fíler apresentaram ganhos de eficiência em relação à convencional, com valor máximo de 20,23\%, alcançado pela mistura com $40 \%$ SM400, e valores negativos calculados para a argamassa com 60\% SM200.

- O ponto principal do presente trabalho é destacar que o uso de fíleres de quartzo em materiais cimentícios apresenta potencial para redução do teor de água nas dosagens, atingindo comportamentos reológicos próximos ao material convencional e desempenhos mecânicos satisfatórios. Embora as resistências mecânicas tenham sido reduzidas com a incorporação de fíleres nas misturas, o consumo de cimento foi reduzido em proporção maior do que a diminuição das resistências, fator comprovado pelos ganhos de eficiência obtidos pelos materiais produzidos. Desse modo, comprova-se que é possível produzir materiais eficientes com desempenho satisfatório e impacto ambiental reduzido, com possibilidade de aplicação na construção civil. 


\section{REFERÊNCIAS BIBLIOGRÁFICAS}

ASTM INTERNATIONAL. ASTM E1876-15: Standard Test Method for Dynamic Young's Modulus, Shear Modulus, and Poisson's Ratio by Impulse Excitation of Vibration. West Conshohocken, 2015.

ASSOCIAÇÃO BRASILEIRA DE NORMAS TÉCNICAS. NBR 7215/96: Cimento Portland - determinação da resistência à compressão. Rio de Janeiro, 1996.

ADJOUDJ, M. Effet des additions minérales et organiques sur le comportement rhéologique du béton. 2015. Tese (Doutorado) - Mécanique des Materiaux. Université de Cergy Pontoise, 2015.

AÏTCIN, P. C. Concreto de alto desempenho. Tradução Geraldo G. Serra. São Paulo: PINI, 2000, 667p.

ATCP ENGENHARIA FÍSICA. Impulse Excitation Tecnique. Disponível em: <http://www.atcp.com.br/>. Acesso em: $10 \mathrm{dez} .2017$.

AÇOBRASIL. Relatório de Sustentabilidade 2016: relatório técnico. Rio de Janeiro: Aço Brasil, 2017. 14p. Disponível em: <http://www.acobrasil.org.br/sustentabilidade/>. Acesso em: 20 fev. 2017.

AGUILAR et al. Expanded bed chromatography, surface energetics of biomass deposition. In: FLICKINGER, M. C. Encyclopedia of Industrial Biotechnology: Bioprocess, Bioseparation, and Cell Technology. [S.I.]: Wiley, 2010. v. 7. p.1-15.

AGÊNCIA NACIONAL DE ENERGIA ELÉTRICA. Atlas de energia elétrica do Brasil: relatório técnico. Brasília: ANEEL, 2008. 233p. Disponível em: <http://www2.aneel.gov.br/arquivos/PDF/atlas3ed.pdf>. Acesso em: 6 fev. 2017.

AMMENBERG, J. et al. Industrial symbiosis for improving the $\mathrm{CO2}$ - performance of cement production: final report of the CEMEX. Linköping: Linkoping University Industrial Ecology Project, 2011. 149p. Disponível em: <http://liu.divaportal.org/smash/get/diva2:474457/FULLTEXT01.pdf> . Acesso em: 18 mar. 2017.

BAETA, G. Otimização do empacotamento de areias para formulação de concretos com baixo consumo de ligantes. 2016. 68p. Relatório final de iniciação científica FAPESP Escola de Engenharia de São Carlos, Universidade de São Paulo, São Carlos, 2016.

BALHOFF et al. Rheological and yield stress measurements of non-Newtonian fluids using a Marsh Funnel. Journal of Petroleum Science and Engineering, v. 105, p. 393-402.

BELTRAME, A. L. et al. Efeitos da alteração do limite de exposição ocupacional à sílica cristalina no processo de seleção de respiradores. Esc. Minas, Ouro Preto, v. 63, n. 4, p. 621625, 2010. Disponível em: <http://www.scielo.br/scielo. php?script=sci_arttext\&pid=S037044672010000400004>. Acesso em: 11 Fev. 2017.

BENAICHA, M. et al. Marsh cone coupled to a plexiglas horizontal channel: Rheological characterization of cement grout. Flow Measurement and Instrumentation, v. 45, p. 126-134, 2015. 
BENEZET, J. C.; BENHASSAINE, A. The influence of particle size on the pozzolanic reactivity of quartz powder. Powder Technology, v. 103, p. 26-29, 1999.

BENTZ, D. P. Replacement of "coarse" cement particles by inert fíleres in low w/c ratio concretes II - Experimental validation. Cement and Concrete Research, v. 35, p. 185-188, 2005.

BENTZ, D. P. et al. Limestone fíleres conserve cement - Durability issues and the effect of limestone fineness on mixtures. Concrete International, v. 31, p. 35-39, 2009. Disponível em:

<https://www.researchgate.net/publication/234838657_Limestone_Fíleres_Conserve_Cement _Part_2_Durability_Issues_and_the_Effects_of_Limestone_Fineness_on_Mixtures>. Acesso em: 20 mar. 2017.

BESSA, A; BIGAS, J. P.; GALLIAS, J. L. Méthode d'evaluation de l'effet des additions minérales sur le besoin en eau et l'adjuvantation des mortiers. Revue Française de Génie Civil, v. 8, p. 181-201. 2004.

BOUVET, A.; GHORBEL, E.; BENNACER, R. The mini-conical slump flow test: Analysis and numerical study. Cement and Concrete Research, v. 40, n. 10, p. 1517-1523, 2010.

BP GROUP. Statistical review of world energy: report. Londres: Securities Exchange Commission, 2016. 48p. Disponível em: <http://www.bp.com/content/dam/bp/pdf/energyeconomics/statistical-review-2016/bp-statistical-review-of-world-energy-2016-fullreport.pdf>. Acesso em: 7 fev. 2017.

CASTRO, A. L. Aplicação de conceitos reológicos na tecnologia dos concretos de alto desempenho. 2007. 302p. Tese (Doutorado) - Escola de Engenharia de São Carlos, Universidade de São Paulo, São Carlos, 2007.

CASTRO, A. L.; PANDOLFELLI, V. C. Revisão: conceitos de dispersão e empacotamento de partículas para a produção de concretos especiais aplicados na construção civil. Cerâmica, v. 55, p. 18-32, 2009.

CASTRO, A. L. DE; LIBORIO, J. B. L.; PANDOLFELLI, V. C. Reologia de concretos de alto desempenho aplicados na construção civil. Cerâmica, v. 57, p. 63-75, 2011.

CICERO. 2017 in review, and 2018 outlook. Magasin om klimaforskning fra, Oslo, 2017. Disponível em: <http://www.cicero.oslo.no>. Acesso em: 03 abr. 2018.

CHEN, C. et al. Flow behaviour of high strength high-performance concrete. Cement and Concrete Composites, v. 21, p. 413-424, 1999.

CHEN, C. et al. LCA allocation procedure used as an incitative method for waste recycling: An application to mineral additions in concrete. Resources, Conservation and Recycling, v.54, p.1231-1240, 2010.

CHOI, M. et al. Estimation of rheological properties of UHPC using mini slump test. Construction and Building Materials, v. 106, p. 632-639, 2016. 
CHERKAOUI, K. et. al. Early age volume changes of extrudable reactive powder concrete. EPJ Web Conference, v. 6, 2010. Disponível em: < http://www.epjconferences.org/>. Acesso em: 22 mar. 2016.

DAMINELI, B. L. et al. Measuring the eco-efficiency of cement use, Cement and Concrete Composites, v. 32, n. 8, p. 555-562, 2010.

DAMINELI, B. L.; JOHN V. M. Developing Low CO2Concretes: Is Clinker Replacement Sufficient? The Need of Cement Use Efficiency Improvement. Key Engineering Materials, v. 517, p. 342-351, 2012

DAMINELI, B. L. Conceitos para formulação de concretos com baixo consumo de ligantes: controle reológico, empacotamento e dispersão de partículas. 2013. 265p. Tese (Doutorado) - Escola Politécnica, Universidade de São Paulo, São Paulo, 2013.

DAMINELI, B. L. et al. Cement and Concrete Research Viscosity prediction of cementfíler suspensions using interference model : a route for binder efficiency enhancement. Cement and Concrete Research, v. 84, p. 8-19, 2016.

DAMTOFT, J. S. et al. Sustainable development and climate change initiatives. Cement and Concrete Research, v. 38, p. 115-127, 2008.

DEPARTAMENTO NACIONAL DE PRODUÇÃO MINERAL. Sumário Mineral: relatório técnico. Brasília: DMPM, 2015. 146p. Disponível em: <http://www.dnpm.gov.br/dnpm/sumarios/sumario-mineral-2015>. Acesso em: 8 fev. 2017.

ESPING, O. Effect of limestone fíler BET $(\mathrm{H} 2 \mathrm{O})$-area on the fresh hardened properties of self-compacting concrete. Cement and Concrete Research, v. 38, p. 938-944, 2008.

FERRARIS, C. F. Measurement of rheological properties of high performance concrete: state of art report. Journal of Research of the National Institute of Standards and Technology, v. 104, p. 461-468, 1999.

FOX, R. W.; McDONALD, A. T. Introdução à mecânica dos fluidos. Rio de Janeiro: Livros Técnicos e Científicos - LTC, 1998. 662p.

FUNDAÇÃO DE CIÊNCIA E TECNOLOGIA. Quantificação das cinzas de carvão fóssil produzidas no Brasil: relatório técnico. Porto Alegre: CIENTEC, 2016. 44p. Disponível em: <http://www.cientec.rs.gov.br/>. Acesso em: 18 fev. 2017.

GALLIAS, J. L.; ALI, K. R.; BIGAS, J. P. The effect of fine mineral admixtures on water requirement of cement pastes. Cement and Concrete Research, v. 30, p. 1543-1549, 2000 .

GATNER, E. Industrially interesting approaches to "low-CO2" cements. Cement and Concrete Research, v.34, p.1489-1498, 2004.

GURIA, C.; KUMAR, R.; MISHRA, P. Rheological analysis of drilling fluid using Marsh Funnel. Journal of Petroleum Science and Engineering, v. 105, p. 62-69, 2013. 
HARBERT, G.; ROUSSEL, N. Study of two concrete mix-design strategies to reach carbon mitigation objectives, Cement and Concrete Composites, v. 31, p.397-402, 2009.

HOENIG, V.; HOPPE, H.; EMBERGER, B. Carbon Capture Technology-Options and Potentials for the Cement Industry. PCA R\&D Serial, Skokie, v.3022, 98p., 2007.

HOOK, M. et al. Global coal production outlooks based on a logistic model. Fuel, v.89, n. 11, p.3546-3558, 2010.

HUNTZINGER, D. N.; EATMON, T. D. A life cycle assessment of Portland cement manufacturing: comparing the traditional process with alternative technologies. Journal of Cleaner Production, v.17, p.668-675, 2009.

INTERNATIONAL ENERGY AGENCY. Global Energy and CO2 Status Report 2017: report. Paris: IEA, 2018. 14p. Disponível em: <https://www.iea.org/>. Acesso em: 03 abr. 2018.

INTERGOVERNMENTAL PANEL OF CLIMATE CHANGE. Climate Change 2007: The Physical Science Basis: report. Cambridge: Cambridge University Press and IPCC, 2007. 996p. Disponível em: < www.ipcc.ch>. Acesso em: 17 mar. 2017.

JACKSON et al. Warning signs for stabilizing global CO2 emissions. Environmental Research Letters, v. 12, n. 11, p. 1-4, 2017.

JOHN, V.M. Cimentos de escória ativada com silicatos de sódio. 1995. Tese (Doutorado) - Escola Politécnica, Universidade de São Paulo, São Paulo, 1995.

JOHN, V. M. Reciclagem de resíduos na construção civil: contribuição para metodologia de pesquisa e desenvolvimento. 2000. 113p. Tese (Livre Docência) - Escola Politécnica, Universidade de São Paulo, São Paulo, 2000.

JOSA, A. et al. Comparative analysis of available life cycle inventories of cement in the EU. Cement and Concrete Research, v. 34, p. 1313-1320, 2004.

KASTING, J. F.; CATLING, D. Evolution of a habitable planet. Annu. Rev. Astron. Astrophys, v. 41, p. 429-63, 2003.

KJELLSEN, K. O.; GUIMARAES, M.; NILSSON, A. The CO2 balance of concrete in a life cycle perspective. Nordic Innovation Centre, Oslo, 34p., dez. 2005. Disponível em: <www.nordicinnovation.net>. Acesso em: 22 de mar. 2016.

LE QUÉRÉ C. et al. Global Carbon Budget 2017. Earth System Science Data: Report. Norwich: Copernicus Publications, 2018. v. 10, p. 405-448. Disponível em: < www.earth-systsci-data.net/10/405/2018/>. Acesso em: 30 mar. 2018.

LIMA, F. M. Avaliação do comportamento reológico de pastas de cimento para poços de petróleo com adição de plastificantes. 2006. 141p. Dissertação (Mestrado) - Centro de Ciências Exatas e da Terra, Universidade Federal do Rio Grande do Norte, Natal, 2006. 
LIMA, J. A. R. Avaliação das consequências da produção de concreto no Brasil para as mudanças climáticas. 2010. 151p. Tese (Doutorado) - Escola Politécnica, Universidade de São Paulo, São Paulo, 2010.

LOTHENBACH, B.; SCRIVENER, K.; HOOTON, R. D. Supplementary cementitious materials. Cement and Concrete Research, v. 41, p. 1244-1256, 2011.

LYRA, J. S. Estudo da influência de policarboxilato comercial na hidratação, reologia e físico-química de superfície do cimento. 2010. 99p. Dissertação (Mestrado) Escola Politécnica, Universidade de São Paulo, São Paulo, 2010.

MAURY, M. B.; BLUMENSCHEIN, R. N. Produção de cimento: impactos à saúde e ao meio ambiente. Sustentabilidade em Debate, v. 3, n. 1, p. 75-96, 2012.

MENEZES, S. O. Minerais comuns e de importância econômica: um manual fácil. São Paulo: Oficina de Textos, 2012.

MONTE, R.; FIGUEIREDO, A. D. Avaliação de métodos de ensaio de fluidez em pastas de cimento com aditivos superplastificantes: boletim técnico. São Paulo: Escola Politécnica da Universidade de São Paulo, 2008. p. 1-14. Disponível em: < http://www.pcc.usp.br/files/text/publications/BT_00478.pdf>. Acesso em: 1 abr. 2017.

NANTHAGOPALAN, P. et al. Investigation on the Influence of granular packing on the flow properties of cementitious suspensions. Cement and Concrete Composites, v. 30, p. 763-768, 2008.

NEHDI, M.; MINDESS, S.; AÏTCIN, P.C. Rheology of highperformance concrete: effect of ultrafine particles, Cement and Concrete Reasearch, v. 28, p. 687-697, 1998.

OLIVEIRA, I. R. et al. Dispersão e empacotamento de partículas: princípios e aplicações em processamento cerâmico. São Paulo: Fazendo Arte Editorial, 2000. 224p.

OLIVEIRA, V. C. et al. Estratégias para a minimização da emissão de CO2 de concretos. Revista Ambiente Construido, v. 14, n. 4, p. 167-181, 2014.

ORGANIZAÇÃO DAS NAÇÕES UNIDAS (ONU). Perspectivas da População Mundial: Revisão de 2017. 2017. 53p. Disponível em: <https://nacoesunidas.org/apesar-debaixa-fertilidade-mundo-tera-98-bilhoes-de-pessoas-em-2050/> . Acesso em: 3 mar. 2018.

ORTEGA, F. S. et al. Aspectos de reologia e da estabilidade de suspensões cerâmicas. Parte II: Mecanismos de estabilidade eletrostática e estérica. Cerâmica, v. 43, n. 280, p. 77-83, 1997.

PILEGGI, R. G. et al. High performance refractory castables: particle size design. Refractories Applications and News, v. 8, n. 5, p.17-21, 2003. 
RASHAD, A. M; ZEEDAN, S. R. A preliminary study of blended pastes of cement and quartz powder under the effect of elevated temperature. Construction and Building Materials, v. 29, p. 672-681, 2012.

REIS, J. F. A. Determinação dos parâmetros reológicos de concretos através do ensaio de abatimento de tronco de cone modificado. 2008. 177f. Dissertação (Mestrado) Faculdade de Engenharia de Ilha Solteira, Universidade Estadual Paulista, Ilha Solteira, 2008.

RICHARDSON, S. M. Non-Newtonian fluids. Thermopedia: A to Z guide to thermodynamics, heat and mass transfer, and fluids engineering. 2011. Disponível em: <http://www.thermopedia.com/content/986/>. Acesso em: 28 mar. 2019.

RICKARD, W. D. A.; GLUTH, G. J. G.; PISTOL, K. In-situ thermo-mechanical testing of fly ash geopolymer concretes made with quartz and expanded clay aggregates. Cement and Concrete Research, v. 80, p. 33-43, 2016.

RIXOM, M. R.; MAILVAGANAM, N. P. Chemical admixtures for concrete. New York: T. Edition, 1999. 437p.

ROUSSEL, N.; LEROY, R. The Marsh cone: A test or a rheological apparatus? Cement and Concrete Research, v. 35, n. 5, p. 823-830, 2005.

ROUSSEL, N.; STEFANI, C.; LEROY, R. From mini-cone test to Abrams cone test: Measurement of cement-based materials yield stress using slump tests. Cement and Concrete Research, v. 35, p. 817-822, 2005.

ROUSSEL, N. A Thixotropy model for fresh fluid concretes: theory, validation and applications. Cement and Concrete Research, v.36, p.1797-1806, 2006.

SANTOS, M. F. M. Avaliação das jazidas de quartzo mais adequadas para uso em sílica vítrea. 2014. 146p. Dissertação (Mestrado) - Faculdade de Engenharia Mecânica, Universidade Estadual de Campinas, Campinas, 2014.

SINDICATO NACIONAL DA INDÚSTRIA DO CIMENTO (SNIC). Relatório anual de 2013. Relatório Técnico. 2013. 40p. Disponível em: <http://www.snic.org.br/>. Acesso em: 17 mar. 2017.

SCHRAMM, G. Reologia e reometria: fundamentos teóricos e práticos. São Paulo: Artliber Editora, 2006. 234p.

SHIHADA, S.; ARAFA, M. Effects of silica fume, ultrafine and mixing sequences on properties of ultra-high performance concrete. Asian Journal of Materials Science, v. 2, p. 137-146, 2010.

STEWART, B. R.; KALYONCU, R. S. Materials flow in production and use of coal combustion products. In: INTERNATIONAL ASH UTILIZATION SYMPOSIUM, 1999, Lexington. Anais eletrônicos... Lexington: University of Kentucky, 1999. 9p. Disponível em: <http://www.flyash.info/1999/econom/kalyon2.pdf>. Acesso em: 06 fev. 2017. 
SU, N.; MIAO, B. A new method for the mix design of médium strenght flowing concrete with low cement content. Cement and Concrete Composites, v. 25, p.215-222, 2003.

TERRA, F. M.; SANTOS, U. P. Silicose. J. bras. Pneumol, v. 32, p.41-47, 2006.

THE FREEDONIA GROUP. Global Demand for Cement to Reach 5.2 Billion Metric Tons in 2019, 2015. Disponível em: <http://www.investorideas.com>. Acesso em: 03 abr. 2018.

UNIVERSIDADE DO ESTADO DO RIO DE JANEIRO (UERJ). O mapa da exposição à sílica no Brasil. Rio de Janeiro: Ministério da Saúde, 2010. 94p. Disponível em: < http://bvsms.saude.gov.br/bvs/publicacoes/mapa_exposicao_silica_brasil.pdf >. Acesso em: 19 mar. 2017.

UNITED STATES GEOLOGICAL SURVEY. Mineral Commodity Summaries 2015: report. United States: USGS, 2015. 196p. Disponível em: < https://minerals.usgs.gov/minerals/pubs/mcs/2015/mcs2015.pdf >. Acesso em: 7 fev. 2017.

UNITED STATES GEOLOGICAL SURVEY (USGS). Mineral Commodity Summaries 2018: report. United States: USGS, 2018. 200p. Disponível em: <https://minerals.usgs.gov/minerals/pubs/mcs/2018/mcs2018.pdf>. Acesso em: 31 mar. 2018.

VAN WAZER, J. R. et al. Viscosity and flow measurement: a laboratory handbook of rheology. New York: Interscience Publishers, 1966. 406p.

VOGT, C. Ultrafine particles in concrete: influence of ultrafine particles on concrete: properties and application to concrete mix design. 2010. $117 \mathrm{f}$. Thesis (Doctoral) - School of Architecture and the Built Environment, Royal Institute of Technology, Stockholm, 2010.

WORLD BUSINESS COUNCIL FOR SUSTAINABLE DEVELOPMENT. The Cement Sustainability Initiative: our agenda for action. Report. Geneva: WBCSD, 2002. 40p. Disponível em: 〈www.wbcsd.org>. Acesso em: 22 mar. 2016.

WORLD BUSINESS COUNCIL FOR SUSTAINABLE DEVELOPMENT. The Lafarge - Partnering for Sustainability. Report. Geneva: WBCSD, 2007. 9p. Disponível em: <www.wbcsd.org>. Acesso em: 22 mar. 2016.

WORLD BUSINESS COUNCIL FOR SUSTAINABLE DEVELOPMENT. The Cement Sustainability Initiative. Report. Geneva: WBCSD 2007. 8p. Disponível em: <www.wbcsd.org>. Acesso em: 22 mar. 2016.

WORLD BUSINESS COUNCIL FOR SUSTAINABLE DEVELOPMENT; INTERNATIONAL ENERGY AGENCY. Cement Tecnology Roadmap 2009 - Carbon Emissions Reductions up to 2050. Report. Geneva: WBCSD, 2009. 36p. Disponível em: <www.wbcsd.org>. Acesso em: 22 mar. 2016.

WORLD BUSINESS COUNCIL FOR SUSTAINABLE DEVELOPMENT; INTERNATIONAL ENERGY AGENCY. Cement Industry Energy and CO2 Performance: Getting the Numbers Right. Report. Geneva: IEA and WBCSD, 2016. 20p. Disponível em: <www.wbcsd.org>. Acesso em: 17 mar. 2017. 
WORLD CEMENT ASSOCIATION (WCA). Cement demand set to rise 1.5 percent in 2018, Uk Reuters, 12 dez. 2017. Disponível em: < https://uk.reuters.com/article/uk-cementoutlook/cement-demand-set-to-rise-1-5-percent-in-2018-world-cement-associationidUKKBN1E61KD>. Acesso em: 05 abr. 2018.

WORLD HEALTH ORGANIZATION. Concise International Chemical Assessment Document 24: Crystalline Silica, Quartz. Report. Geneva, 2000. (WHO technical report series). Disponível em: < http://www.who.int/ipcs/publications/cicad/en/cicad24.pdf>. Acesso em: 19 mar. 2017.

WORLD STEEL ASSOCIATION. Crude steel production press releases: report. Bruxelas: WSA, 2016. 4p. Disponível em: < https://www.worldsteel.org/>. Acesso em: 02 mar. 2017. 